\title{
AFRICAN INITIATED CHRISTIANITY AND THE DECOLONISATION OF DEVELOPMENT
}

SUSTAINABLE DEVELOPMENT IN PENTECOSTAL AND INDEPENDENT CHURCHES

Edited by

Philipp Öhlmann, Wilhelm Gräb, and Marie-Luise Frost 


\section{African Initiated Christianity and the Decolonisation of Development}

This book investigates the substantial and growing contribution which African Independent and Pentecostal Churches are making to sustainable development in all its manifold forms. Moreover, this volume seeks to elucidate how these churches reshape the very notion of sustainable development and contribute to the decolonisation of development.

Fostering both overarching and comparative perspectives, the book includes chapters on West Africa (Nigeria, Ghana, and Burkina Faso) and Southern Africa (Zimbabwe and South Africa). It aims to open up a subfield focused on African Initiated Christianity within the religion and development discourse, substantially broadening the scope of the existing literature. Written predominantly by scholars from the African continent, the chapters in this volume illuminate potentials and perspectives of African Initiated Christianity, combining theoretical contributions, essays by renowned church leaders, and case studies focusing on particular churches or regional contexts.

While the contributions in this book focus on the African continent, the notion of development underlying the concept of the volume is deliberately wide and multidimensional, covering economic, social, ecological, political, and cultural dimensions. Therefore, the book will be useful for the community of scholars interested in religion and development as well as researchers within African studies, anthropology, development studies, political science, religious studies, sociology of religion, and theology. It will also be a key resource for development policymakers and practitioners.

Philipp Öhlmann is Head of the Research Programme on Religious Communities and Sustainable Development, Humboldt-Universität zu Berlin, and Research Associate, University of Pretoria, South Africa.

Wilhelm Gräb is Head of the Research Programme on Religious Communities and Sustainable Development, Humboldt-Universität zu Berlin, and Extraordinary Professor, Stellenbosch University, South Africa.

Marie-Luise Frost is a Researcher, Research Programme on Religious Communities and Sustainable Development, Humboldt-Universität zu Berlin, and Research Associate, University of Pretoria, South Africa. 


\title{
Routledge Research in Religion and Development
}

The Routledge Research in Religion and Development series focuses on the diverse ways in which religious values, teachings and practices interact with international development.

While religious traditions and faith-based movements have long served as forces for social innovation, it has only been within the last ten years that researchers have begun to seriously explore the religious dimensions of international development. However, recognising and analysing the role of religion in the development domain is vital for a nuanced understanding of this field. This interdisciplinary series examines the intersection between these two areas, focusing on a range of contexts and religious traditions.

\section{Series Editors:}

Matthew Clarke, Deakin University, Australia

Emma Tomalin, University of Leeds, UK

Nathan Loewen, Vanier College, Canada

\section{Editorial board:}

Carole Rakodi, University of Birmingham, UK

Gurharpal Singh, School of Oriental and African Studies, University of London, UK

Jörg Haustein, School of Oriental and African Studies, University of London, UK

Christopher Duncanson-Hales, Saint Paul University, Canada

\section{Negotiating Religion and Development}

Identity Construction and Contention in Bolivia

Arnhild Leer-Helgesen

\section{Tearfund and the Quest for Faith-Based Development Dena Freeman}

\author{
African Initiated Christianity and the Decolonisation of Development \\ Sustainable Development in Pentecostal and Independent Churches \\ Edited by Philipp Öhlmann, Wilhelm Gräb, and Marie-Luise Frost \\ The Sarvodaya Movement \\ Holistic Development and Risk Governance in Sri Lanka \\ Praveena Rajkobal
}




\section{African Initiated Christianity and the Decolonisation of Development}

Sustainable Development in Pentecostal and Independent Churches

Edited by

Philipp Öhlmann,

Wilhelm Gräb, and

Marie-Luise Frost 
First published 2020

by Routledge

2 Park Square, Milton Park, Abingdon, Oxon OX14 4RN

and by Routledge

52 Vanderbilt Avenue, New York, NY 10017

Routledge is an imprint of the Taylor $\mathfrak{E}$ Francis Group, an informa business

(C) 2020 selection and editorial matter, Philipp Öhlmann, Wilhelm Gräb, and Marie-Luise Frost; individual chapters, the contributors

The right of Philipp Öhlmann, Wilhelm Gräb, and Marie-Luise Frost to be identified as the authors of the editorial material, and of the authors for their individual chapters, has been asserted in accordance with sections 77 and 78 of the Copyright, Designs and Patents Act 1988.

The Open Access version of this book, available at www.taylorfrancis. com, has been made available under a Creative Commons AttributionNon Commercial-No Derivatives 4.0 license.

Trademark notice: Product or corporate names may be trademarks or registered trademarks, and are used only for identification and explanation without intent to infringe.

British Library Cataloguing-in-Publication Data

A catalogue record for this book is available from the British Library

Library of Congress Cataloging-in-Publication Data

A catalog record has been requested for this book

ISBN: 978-0-367-35868-6 (hbk)

ISBN: 978-0-367-82382-5 (ebk)

Typeset in Goudy

by Wearset Ltd, Boldon. Tyne and Wear 


\section{Contents}

List of illustrations $\quad$ ix

List of contributors $\quad \mathbf{x}$

Acknowledgements $\quad \mathbf{x v}$

1 Introduction: African Initiated Christianity and sustainable development

PHILIPP ÖHLMANN, WILHELM GRÄB, AND

MARIE-LUISE FROST

\section{PART I}

Overarching perspectives

2 Spirit and empowerment: the African Initiated Church movement and development

J. KWABENA ASAMOAH-GYADU

3 The challenge of environment and climate justice: imperatives of an eco-theological reformation of Christianity in African contexts

DIETRICH WERNER

4 African Initiated Churches and development from below: subjecting a thesis to closer scrutiny

5 Distinguished church leader essay: Theology in African Initiated Churches - reflections from an East African perspective 
vi Contents

PART II

Nigerian perspectives

6 Distinguished church leader essay: Roles of women in African Independent and Pentecostal Churches in Nigeria ATINUKE ABDULSALAMI

7 'A starving man cannot shout halleluyah': African Pentecostal Churches and the challenge of promoting sustainable development

OLUFUNKE ADEBOYE

8 Approaches to transformation and development: the case of the Redeemed Christian Church of God, Nigeria

9 The role of Pentecostalism in sustainable development in Nigeria

MOBOLAJI OYEBISI AJIBADE

10 Aladura Churches as agents of social transformation in South-West Nigeria

AKINWUMI AKINDOLIE

11 Distinguished church leader essay: Aladura theology - the case of the Church of the Lord (Prayer Fellowship) Worldwide

PART III

Ghanaian perspectives

12 Distinguished church leader essay: The Church of Pentecost and its role in Ghanaian society

OPOKU ONYINAH

13 An evaluation of Pentecostal Churches as agents of sustainable development in Africa: the case of the Church of Pentecost 
14 Pentecostalism and sustainable development: the case of Perez Chapel International

15 Distinguished church leader essay: Healing a strained relationship between African Independent Churches and western Mission-founded Churches in Ghana (1967-2017) the role of Good News Theological Seminary, Accra, Ghana THOMAS A. ODURO

\section{PART IV}

Perspectives from Burkina Faso

16 Distinguished church leader essay: Partnerships for female education in Burkina Faso - perspectives from Evangelical Churches and FBOs

PHILIPPE OUEDRAOGO

17 Centre International d'Evangélisation/Mission Intérieure Africaine's contribution to sustainable development in Burkina Faso through transformational development INI DORCAS DAH

PART V

Zimbabwean perspectives

18 Investing in the future generation: new Pentecostal Charismatic Churches in Harare, Zimbabwe

19 Pentecostal Charismatic Christianity and the management of precarity in postcolonial Zimbabwe

JOSIAH TARU

\section{PART VI}

South African perspectives

20 Distinguished church leader essay: Cross-cultural development in South Africa - a perspective from below 
viii Contents

21 Contested development(s)? The possible contribution of the African Independent Churches in decolonising development: a South African perspective

NADINE BOWERS-DU TOIT

Index 


\section{Illustrations}

\section{Figures}

1.1 Three waves of African Initiated Christianity 7

1.2 Membership of African Initiated Churches 11

Table

4.1 Overview of literature capturing the development-from-below thesis 


\section{Contributors}

Atinuke Abdulsalami is ordained prophetic minister and pastor of Shepherd's Court Christian Centre and Divine Salvation Bible Church in Lagos, Nigeria. She is the initiator and president of Women of Prayers in Nigeria Fellowship, which has over 2000 members all over Nigeria. She is a certified family, marriage and relationship counsellor of the Institute of Counselling, United Kingdom. Abdulsalami has received several awards and is presently the secretary of the board of trustees of the Fellowship of Christian Ministers of Nigeria. She is the first woman in that position.

Philip Adjei-Acquah is a researcher and adjunct lecturer in Pentecostal/Charismatic Theology and Missions at Central University and Perez University College, Ghana. He is also a minister with the International Central Gospel Church. He serves as a conference speaker and leadership mentor with the passion of empowering the youth. His graduate thesis was titled 'An evaluative study of the mission strategy in ICGC in relation to its growth' (2016) and Adjei-Acquah is author of the book How to develop the leader in you (2015).

Olufunke Adeboye is a professor of Social History at the University of Lagos, Nigeria. She was a visiting research associate at the Harriet Tubman Institute, York University, Canada, and has held visiting research fellowships at University of Birmingham, University of Massachusetts, Amherst College and University of Cambridge. Her research interests include gender in Africa, African historiography, and Pentecostalism in West Africa. In 2013, her article 'A Church in a Cinema Hall? Pentecostal Appropriation of Public Space in Nigeria', Journal of Religion in Africa (2012) won the Gerti Hesseling Prize.

Babatunde A. Adedibu holds a PhD in Missiology from North West University, South Africa. He is the provost of the Redeemed Christian Bible College and an affiliate of University of Ibadan, Nigeria. Adedibu is also an associate professor with Redeemer's University, Nigeria, and a research fellow at Stellenbosch University in South Africa. Adedibu is the co-editor of the book The Changing Faces of African Pentecostalism (2018) and convener of the International Conference on African Pentecostalism. 
Mobolaji Oyebisi Ajibade teaches Sociology of Religion and Pedagogy at Obafemi Awolowo University, Nigeria. Ajibade holds a Master of Arts in Religious Studies from the University of Bayreuth, Germany, and a $\mathrm{PhD}$ in Religious Studies from Obafemi Awolowo University. She was the former assistant director of the Centre for Gender and Sustainable Development Studies, ACE, Obafemi Awolowo University. Ajibade's current research focuses on education on HIV/AIDS using religious media - electronic and prints.

Akinwumi Akindolie is a doctoral student of Sociology of Religion at University of Ibadan, Nigeria. He lectures at the Redeemed Christian Bible College, Main Campus, Redemption Camp. His publications include 'The Church and Educational Investment in Nigeria: Prospects and Problems', Journal of African Society for the Study of Sociology and Ethics of Religions (2018) and 'Is Church God's Business or Man's? An Exegesis of Acts 20:28-31', Akungba Journal of Religion Eु African Culture (jointly with Akintunde Felix, 2018).

Emmanuel Kwesi Anim is the principal of the Pentecost Theological Seminary, Ghana. He is a visiting lecturer to the All Nations Christian College, UK, where he teaches African Studies and Church Planting. Anim is also an adjunct lecturer at the Pentecost University College and the Akrofi-Christaller Institute of Theology, Mission and Culture, Ghana. Among his publications are Mission, Migration and World Christianity: An Evaluation of the Mission Strategy of The Church of Pentecost in the Diaspora (2016) and Pentecostal Theological Education - A Ghanaian Perspective (2013, with Opoku Onyinah).

J. Kwabena Asamoah-Gyadu is the president and Baëta-Grau Professor of Contemporary African Christianity and Pentecostal Theology of the Trinity Theological Seminary, Legon, Ghana. He has served as visiting scholar to Harvard University, Luther Seminary, Overseas Ministries Study Center, visiting professor to Asbury Theological Seminary, USA, and Yonsei International University, South Korea. Asamoah-Gyadu is a member of the Lausanne Theology Working Group and is author of Sighs and Signs of the Spirit (2015) as well as lead editor of Between Babel and Pentecost: Migrant Readings from Africa, Europe and Asia (2013).

Nadine Bowers-Du Toit is associate professor of Theology and Development at University of Stellenbosch and the director of the Unit for Religious and Development Research. Her research and publications have focused on the role of faith communities in addressing issues of social injustice and poverty, with a particular focus on local congregations and grassroots faith-based actors. She serves on the board of two non-governmental organisations and is the chairperson of the Society of Practical Theology in South Africa.

Ini Dorcas Dah is associate professor of l'Institut Pastoral Hébron, Côte d'Ivoire, and an adjunct research fellow at the Akrofi-Christaller Institute of Theology, Mission and Culture, Ghana. She is founding president of l'Association Evangélique pour la Joie et le Développement de la Femme, 
Burkina Faso. Dah has published Women Do More Work Than Men: Birifor Women as Change Agents in the Mission and Expansion of the Church in West Africa (2017) and various articles. Her research interests are Christian history, gospel and culture, and holistic mission and development.

Marie-Luise Frost is a researcher in the Research Programme on Religious Communities and Sustainable Development at Humboldt-Universität zu Berlin and research associate at University of Pretoria. Besides freelance activities in the cultural field, she has taught several courses on religion and development. Her publications include the chapter "Avoiding "White Elephants" - Fruitful Development Cooperation from the Perspective of AICs in South Africa and Beyond' (2018, with Philipp Öhlmann and Wilhelm Gräb) and the article 'African Initiated Churches' potential as development actors' (with Philipp Öhlmann and Wilhelm Gräb), HTS Theological Studies (2016).

John Njeru Gichimu is an archdeacon in the African Independent Pentecostal Church of Africa. He joined the Organization of African Instituted Churches in 1995 as a facilitator for Theological Education by Extension and is currently the director of the Programme for Theology and Ministerial Formation. Gichimu studied theology at Kima Theological College in Kenya, at the Lutheran Theological College in Tanzania and holds a Master of Arts in Mission Studies from Birmingham University, UK.

Wilhelm Gräb is head of the Research Programme on Religious Communities and Sustainable Development and extraordinary professor at Stellenbosch University. He is involved in several international research projects on the role of African Christianity in processes of social transformation. Recent publications include Vom Menschsein und der Religion. Eine praktische Kulturtheologie (2018) and The Impact of Religion on Social Cohesion, Social Capital Formation and Social Development in Different Cultural Contexts (2014, edited with Lars Charbonnier).

Simbarashe Gukurume is a researcher and lecturer at Great Zimbabwe University. He holds a $\mathrm{PhD}$ in Sociology from the University of Cape Town in South Africa. Gukurume received his MSc degree in Sociology and Social Anthropology from the University of Zimbabwe. His research interests focus on youth, social movements and protests, student activism and livelihoods. Gukurume was a Matasa Network fellow at the Institute for Development Studies, University of Sussex, a Harry Frank Guggenheim Young African Scholars fellow, and an Academy for African Urban Diversity fellow at Max Planck Institute, Germany.

Thomas A. Oduro is the president of Good News Theological Seminary in Accra, Ghana. He has been teaching, leading and coordinating seminars and workshops in many African countries. He is a member of the executive committee of the Organization of African Instituted Churches and pastor of Christ Holy Church International. Oduro holds a $\mathrm{PhD}$ in History of 
Christianity. Among his publications are Leading People to Christ: Using events in Your Life to lead People to Christ (2017) and Church of the Lord (Brotherhood): History, Challenges and Growth (2016).

Philipp Öhlmann heads the Research Programme on Religious Communities and Sustainable Development at Humboldt-Universität zu Berlin and is a research associate at University of Pretoria. Öhlmann's research focuses on the effects of religion on economic performance as well as African Christianity and sustainable development. His publications include 'Religiosity and household income in Sekhukhune' (with Silke Hüttel), Development Southern Africa (2018) and 'African Initiated Churches' potential as development actors' (with Marie-Luise Frost and Wilhelm Gräb), HTS Theological Studies (2016).

Opoku Onyinah is the immediate past chairman of the Church of Pentecost, with its headquarters in Ghana and a former president of Ghana Pentecostal and Charismatic Council. Currently he is a member of the Commission of Religious Freedom of the World Pentecostal Fellowship. One of his publications is Pentecostal Exorcism: Witchcraft and Demonology in Ghana (2012).

Rufus Okikiola Ositelu is the Metropolitan Archbishop and the Primate of The Church of the Lord (a.k.a Aladura). He was installed as the Pope of the Aladura Communion Worldwide in 2009 and is currently vice president of the Christian Council of Nigeria. Ositelu holds PhDs in Computer Science and Religious Studies. He is a prolific writer and author of African Instituted Churches: Diversities, Growth, Gifts, Spirituality and Ecumenical Understanding of African Initiated Churches (2002) and CHRISTIANITY: Inside Story from an African Perspective (2016).

Philippe Ouedraogo is the executive director of the Association Evangélique d'Appui au Développement, senior pastor of Boulmiougou Assemblies of God Church, Ouagadougou, and vice president of Assemblies of God Churches of Burkina Faso. He holds a PhD from the Oxford Centre of Mission Studies, UK, and an MPhil from New Covenant International University, Florida. He is currently working to advocate with families, churches/NGOs and the Government of Burkina Faso for a quality access to female education.

Sylvia Owusu-Ansah is a lecturer at Central University, Ghana, and the head pastor of Revival Temple, Perez Chapel International, Accra. Her research interests include missions-related studies, cross-cultural communication, gender studies, interreligious conflict mediation, and dialogue. Among her publications are the book chapters 'The Role of Interreligious Collaboration in Conflict Prevention and Peaceful Multi-Religious Co-Existence: A Case Study of Northern Ghana' (2018) and 'Neo-Pentecostalism in Postcolonial Ghana' (2018).

Ignatius Swart is professor in the Department of Religion and Theology at the University of the Western Cape and Kjell Nordstokke Professor of 
International Diaconia at VID Specialized University, Norway. He has initiated and led several international team research projects since the early 2000s, which emanated in anthologies and other forms of academic publication. Examples include the anthology Religion and Social Development in PostApartheid South Africa: Perspectives for Critical Engagement (2010) and the special collection in HTS Theological Studies, Engaging Development: Contributions to a Critical Theological and Religious Debate (2016).

Josiah Taru is a lecturer in the Department of Sociology and Social Anthropology at Great Zimbabwe University. He is a fellow of the Human Economy Research Programme at University of Pretoria. His research interests are Pentecostalism's engagement with postcolonial Zimbabwean state, PentecostalCharismatic Christianity, Consumption Patterns and Money. His publications include 'Patterns of Consumption and Materialism among Zimbabwean Christians: A Tale of Two Indigenous Churches', Journal for the Study of Religion (2015, with Federico Settler).

Dietrich Werner is senior theological advisor to Bread for the World, the German Protestant Churches' agency for development cooperation. He is also honorary professor for Intercultural Theology, Ecumenism and Development Studies at the University of Applied Sciences in Hermannsburg, Germany. He previously worked as director of the Ecumenical Theological Education Programme of the World Council of Churches. Werner has published widely on ecumenical theology, development and education, e.g. Anthology of African Theology (2014) and Handbook of Theological Education in World Christianity (2010).

Danie C. van Zyl is research fellow of Department of Biblical Studies at University of Stellenbosch, has worked in cross-cultural Christian ministry his whole life. He first ministered in a rural Xhosa-speaking community, close to Nelson Mandela's place of birth. For the major part of his ministry, he conducted an interdenominational pastors-training programme for lay leaders in Cape Town. The majority of these leaders were from African Initiated Churches. Through spiritual and personal development of people, he has sought to encourage and equip leaders for doing social and physical development themselves in their own contexts. 


\section{Acknowledgements}

This volume emerged within the context of the research project 'Potentials of Cooperation with African Initiated Churches for Sustainable Development' conducted by the Research Programme on Religious Communities and Sustainable Development at Humboldt-Universität zu Berlin under the leadership of Philipp Öhlmann and Wilhelm Gräb. The project was highly collaborative, drawing on the expertise of numerous international academic experts on African Initiated Christianity, many of whom have contributed chapters to this book. The volume includes chapters presented at workshops in Kasoa (Ghana), Pretoria (South Africa), and Berlin (Germany) in 2017 and 2018. These workshops not only involved researchers, but also church leaders and representatives of African Initiated Churches. Moreover, in the framework of Lecture Series on African Independent and Pentecostal Approaches to Theology and Development at Humboldt-Universität zu Berlin's Faculty of Theology in 2017 and 2018, leaders of African Initiated Churches had the historic opportunity of giving keynote lectures at a major European theological faculty. We are delighted to be able to incorporate these keynote lectures as distinguished church leader essays in this volume.

Several notes of thanks are in order. First of all, we would like to sincerely thank the authors of the 20 chapters for contributing to this volume and for the willingness to revise their chapters in some cases multiple times in light of reviewers' and editors' remarks. Second, sincere thanks are due to our team at the Research Programme on Religious Communities and Sustainable Development for their hard work on this book. Especially, Juliane Stork and Daniel Schumacher provided excellent editorial assistance exceeding any expectations. Ms Stork accompanied the volume from the very early stages on, working with us on the project for nearly two years. She excellently managed the communications with the authors from the first draft to the final manuscript and ensured swift and high-quality editing of all chapters. She was not merely an editorial assistant, but in many ways also an editorial advisor to us in providing valuable input on the entire volume. Mr Schumacher meticulously formatted and checked all chapters in the final stages of the editorial process. Third, we would like to express our appreciation for the constructive engagement of Routledge on this volume, particularly of their development studies editor, Helena Hurd, 
xvi Acknowledgements

and her team. Fourth, we are indebted to two anonymous reviewers, who critically engaged with the proposal for this volume and provided constructive and helpful advice. Last, but not least, we gratefully acknowledge the financial support of the research project this volume emerged from by the German Federal Ministry of Economic Cooperation and Development.

Philipp Öhlmann, Wilhelm Gräb, and Marie-Luise Frost 


\title{
1 Introduction
}

\section{African Initiated Christianity and sustainable development}

\author{
Philipp Öhlmann, Wilhelm Gräb, and \\ Marie-Luise Frost
}

\section{Approaching the field: religion and development}

The past 20 years have witnessed a 'religious turn' (Kaag and Saint-Lary 2011, 1) in international development theory, policy, and practice. A growing corpus of literature has begun to explore the manifold relationships and interactions of religion and development (Jones and Petersen 2011; Swart and Nell 2016) - in themselves two vast fields of research. Religion and development is of crossdisciplinary interest, with research spanning from religious studies and theology (e.g. Gifford 2015; Heuser 2013, 2015) to anthropology (e.g. Bornstein 2005; Freeman 2012b), sociology (e.g. Berger 2010), politics (e.g. Bompani 2010; Clarke and Jennings 2008), development studies (e.g. Deneulin and Bano 2009), and economics (e.g. Barro and McCleary 2003; Beck and Gundersen 2016; Guiso, Sapienza, and Zingales 2003). A new interdisciplinary and dynamic research field on religion and development has emerged (Bompani 2019; Ter Haar 2011; Tomalin 2015).

At the same time, development policymakers and practitioners have recognised religion as a relevant factor (Tomalin 2015). Leading examples are the initiatives by the World Bank, the British Department for International Development, and, more recently, the initiative by the German Federal Ministry of Economic Cooperation and Development, inter alia leading to the foundation of the International Partnership on Religion and Sustainable Development (Belshaw, Calderisi, and Sugden 2001; BMZ 2016; Deneulin and Rakodi 2011; Ter Haar 2011). The recent interest in the relationship of development and religion is not limited to governmental and multilateral institutions, but extends to religious communities and institutions as illustrated by a volume published by the Lutheran World Federation in 2013 (Mtata 2013) and the special issue on religion and development of the Ecumenical Review published by the World Council of Churches in 2016.

However, the current religion and development discourse has largely been taking place within the secular frameworks of the western-dominated development discourses. Where religious communities come into view, the perspective is mainly functional: it asks whether religion is conducive to development or hinders it (e.g. Basedau, Gobien, and Prediger 2018). The focus of the attention 


\section{Philipp Öhlmann et al.}

is on the contribution of religious communities to secular development agendas (Deneulin and Bano 2009; Jones and Petersen 2011). As we have pointed out elsewhere

[t]he development agenda and imagination, as framed in (inter-) governmental strategies such as the Agenda 2030 for Sustainable Development ... remains a secular one. Nowhere in the United Nations resolution on the Sustainable Development Goals (SDGs) is religion or are religious communities mentioned explicitly.

(Öhlmann et al. 2018, 4)

This secular framework of the development discourse is not only challenged by the decolonial and postcolonial debate (e.g. Mawere 2014; Bowers-Du Toit, Chapter 21 , this volume), but also by the perspective of religious actors themselves. For many religious communities 'development is part of religion', i.e. professional and academic experts' notions of development represent only one dimension in a more comprehensive human and social transformation (Öhlmann, Frost, and Gräb $2016,10)$ that is informed by and interrelated with religious, situated and indigenous knowledge. In this it is vital to also recognise that " $\mathrm{f}]$ or most people in the developing world, religion is part of a vision of the "good life" ... [R]eligion is part of the social fabric, integrated with other dimensions of life' (Ter Haar 2011, 5-6). Van Wensveen (2011) introduced a twofold typology of the contributions of religious communities to sustainable development, differentiating between an 'additive pattern' and an 'integral pattern'. Development concepts and practices that follow secular western development policies can be characterised as making an 'instrumental addition of religion to the pre-set, mechanistic sustainable development production process' (van Wensveen 2011, 85). In difference to this 'additive pattern', she identifies an opposite model, in which religion does not function as an instrument for secular development goals, but in which religious communities set the agenda bringing to the table their own religious-inspired concepts and practices of sustainable development. '[D]evelopment as part of religion' (Öhlmann, Frost, and Gräb 2016, 10) encapsulates precisely this 'integral pattern' brought forward by van Wensveen (2011).

While in the functional approach religious communities are viewed as actors of 'mainstream development policies and programmes' (van Wensveen 2011, 82), their own aims go beyond the specific concepts of sustainable development outlined e.g. in the UN Agenda 2030 for Sustainable Development (United Nations 2015). This can imply a fundamental critique of dominant concepts of (sustainable) development. They (re)shape the very notions of development based on their religious worldviews and their situated knowledge due to the embeddedness in local contexts and cultures (see Bowers-Du Toit, Chapter 21, this volume). This is what we refer to as a process of decolonisation of development in the title of this volume.

Hence, one desideratum in the research field is to juxtapose the notions of development dominant in (western and international) development policy with 
those of religious communities and to illuminate their respective ideological presuppositions. Alternative notions of development informed by contextual religious and cultural worldviews, such as holistic development (Owuso-Ansah and Adjei-Acquah, Chapter 14, this volume), integral development (Cochrane 2011), transformation or transformational development (Dah, Chapter 17, this volume; Masondo 2013; Myers 2011); human flourishing (Asamoah-Gyadu, Chapter 2, this volume; Marais 2015 ), Ubuntu (Bowers-Du Toit, Chapter 21, this volume; Gichimu, Chapter 5, this volume; Metz 2011; Padwick and Lubaale 2011); good life (Acosta 2016, Taru, Chapter 19, this volume); and prosperity (AsamoahGyadu, Chapter 2, this volume; Ajibade, Chapter 9, this volume; Gukurume, Chapter 18, this volume; Taru, Chapter 19, this volume; Togarasei 2016), need to be taken into account and their relationship to dominant secular notions of development and modernity needs to be investigated.

This volume situates itself within the dynamic research field of religion and development by elucidating the role of African Initiated Christianity for sustainable development. While mission-initiated Christianity in Africa, in the shape of the Catholic and historic Protestant Churches of European and North American provenience, have long been recognised as development actors both in the academic literature and in the international development policy discourse (see, e.g. Belshaw, Calderisi, and Sugden 2001; BMZ 2016; Gifford 2015; Ilo 2014), African Initiated Christianity in the shape of African Independent and Pentecostal Churches lack such recognition. Thus far, there are only a limited number of studies investigating African Independent and Pentecostal Churches' contribution to development. Notable works in this area include, for example, the comprehensive overview by Turner (1980), the contributions by Oosthuizen and his collaborators (Cross, Oosthuizen, and Clark 1993; Oosthuizen 1997, 2002) or more recent contributions by Garner (2004), Bompani (2008, 2010), Freeman (2012a), and Öhlmann, Frost, and Gräb (2016). These studies indicate that there is a substantial and growing dynamic in the contribution made by African Independent and Pentecostal Churches to sustainable development in its manifold forms. Acknowledging the role of these religious movements as actors of sustainable development requires acknowledging their understanding of sustainable development as well as the wider notions and ideas that undergird and guide their actions. As decolonial and postcolonial religious movement, African Initiated Churches seem to be ideally positioned to contribute to decolonising concepts of sustainable development. Moving beyond a functional approach assessing contributions of religious communities to a secular development agenda, this volume furthermore seeks to elucidate how African Initiated Christianity contributes to reshaping notions of sustainable development.

The study of the relationship of African Initiated Christianity and sustainable development, hence, constitutes an important strand within the religion and development research field. Taking this as a point of departure, it is the aim of this book to substantially broaden the scope of the existing literature through contributions on African Independent and Pentecostal Churches and the 


\section{Philipp Öhlmann et al.}

different dimensions and forms of development in Africa from different thematic and disciplinary perspectives. Since much of the existing literature deals with South Africa (inter alia Bompani 2008, 2010; Cross, Oosthuizen, and Clark 1993; Öhlmann, Frost, and Gräb 2016; Masondo 2014; Oosthuizen 1997; Schlemmer 2008), this volume puts the West African context into the centre of attention (including case studies on Nigeria, Ghana, and Burkina Faso). To foster overarching and comparative perspectives, it also includes contributions with a panAfrican scope and contributions on the Southern African context (Zimbabwe and South Africa). The perspective presented here is necessarily partial. Hence, the volume provides an important first step in a more comprehensive investigation of African Initiated Christianity and sustainable development. It intends to open up a subfield focused on African Initiated Christianity within the religion and development discourse, while at the same time acknowledging the need for further case studies in other African countries and regions and focusing on additional notions and subthemes of sustainable development.

\section{Approaching African Initiated Christianity: towards a definition of African Initiated Churches}

African Christianity fundamentally changed in the past 100 years. In what Allan Anderson (2001) termed African Reformation, new African expressions of Christianity emerged: the African Initiated Churches. While at the beginning of the twentieth century African Christianity was predominantly marked by the historic Protestant, Catholic (and, in the North East of the continent, Orthodox) Churches, today about one-third of Africa's Christians can be estimated to be members of African Initiated Churches.

For the purposes of this volume and the research initiative it emerged from, we define African Initiated Churches as all those Christian religious communities that have their origins in nineteenth- and twentieth-century Africa (Anderson $2000,2001)$. We draw on the original typology by $\operatorname{Turner}(1967,17)$ to refer to churches that are 'founded in Africa, by Africans, and primarily for Africans' without 'missionary Godfathers' as Pobee and Ositelu (1998, 55) pointedly added. Their key feature is that they were founded by Africans and did not directly emerge from the European and North American mission initiatives of the nineteenth and twentieth centuries. ${ }^{1}$ This closely relates to the definition used by the Organization of African Instituted Churches (OAIC), which

understands an AIC to be a church that acknowledges Jesus Christ as Lord, and which has separated by seceding from a mission church or an existing African independent church, or has been founded as an independent entity under African initiative and leadership.

(Gichimu 2016, 810)

To emphasise this overarching common characteristic of being initiated in Africa by Africans, we deliberately use the term African Initiated Churches instead of 
other commonly used interpretations of the 'I' in AIC such as Independent, Indigenous, and International (see Venter 2004a for an overview). We argue that there are enough common characteristics to necessitate the use of this umbrella term. In the literature, the acronym AIC is often used to refer exclusively to churches originating in the first and second waves of African Initiated Christianity (see below). In this volume, we adopt the following systematisation to accommodate the different approaches in the literature: the term African Initiated Churches denotes all churches originating in nineteenth- and twentieth-century Africa, including African Pentecostal and Pentecostal-Charismatic Churches. The term African Independent Churches will be used to denote all churches that can be counted as part of the first and second waves of African Initiated Christianity, i.e. Independent/African/Separatist/Nationalist/Apostolic/Zionist/ Roho/Aladura/Spiritual/Indigenous Churches. This is coherent with the earlier literature (Oosthuizen 1987; Turner 1980, 1967). The terms African Pentecostal and Pentecostal-Charismatic Churches will be used to describe the Pentecostal and Neo-Pentecostal strands of African Initiated Christianity. Coherent with the volume's emphasis on case studies from the West African context, many of the contributions deal with African Pentecostal and Neo-Pentecostal Churches, which have been developing in a highly dynamic way in the past decades and constitute the major part of African Initiated Christianity in the region (Asamoah-Gyadu 2005; Meyer 2004).

African Initiated Churches do not form a clearly delimited denominational family (Hollenweger 1998). Rather, they are a heterogeneous movement (Pauw 1995) of probably more than 10,000 churches of different expressions, whose primary commonality is their formation in colonial and postcolonial Africa of the nineteenth and twentieth centuries. The smallest of them have just a handful of members, while the largest, such as the Zion Christian Church in South Africa or the Redeemed Christian Church of God in Nigeria, claim membership in the millions. We acknowledge that an idiotypical African initiated church does not exist and that various different subcategorisations are important analytical tools dependent on the questions of interest. To understand the movement of African Initiated Churches and the categorisation employed here, it is helpful to look at the history and development of these churches. The following categorisation and terminology follow Gichimu (2016) and Padwick and Lubaale (2011). Three waves of African Initiated Christianity can be highlighted, which produced different subcategories of African Initiated Churches (cf. Figure 1.1).

The first churches falling under the categorisation of African Initiated Churches employed here, emerged as secessions from Mission Churches (Sundkler 1961). In an anti-colonial move in the churches, African Christians split from the churches founded and supervised by European and North American missionaries and founded churches under their own leadership. In many cases, notably in late-nineteenth- and early-twentieth-century Southern Africa as well as twentieth-century pre-independence East Africa, cross-fertilisation existed between political independence movements and independence movements in 


\section{Philipp Öhlmann et al.}

the churches. In their theology and structure, the newly independent churches were often similar to the churches from which they seceded (Sundkler 1961; Venter 2004a). Because of the focus on independence from foreign leadership, these churches were termed Independent, Separatist, or Nationalist. In the different African regions, different self-designations exist: African Churches in West Africa, Ethiopian Churches ${ }^{2}$ in Southern Africa, Independent Churches or Nationalist Churches in East Africa (Gichimu 2016; Sundkler 1961). Some of these first-generation African Independent Churches still exist, such as the Lutheran Bapedi Church in South Africa, which seceded from the Berlin Mission Church in the late-nineteenth century. Nonetheless, nowadays the firstgeneration African Independent Churches in their original form play a marginal role (with the exception of East Africa, particularly Kenya). Many of them have either since disappeared or have incorporated elements of African traditional religious or Pentecostal elements of belief, so that they can be considered as African Initiated Churches of the second or third generations.

The second generation of African Initiated Churches emerged principally since the beginning of the twentieth century. While in the first generation the focus was on autonomy, the second generation is characterised by indigenisation and hybridisation. Elements of African traditional religions and local cultures were incorporated into Christian religious practice and belief. These churches are characterised by a worldview that assumes spiritual forces to be intertwined with the social and material world, synthesising African spiritual worldviews with Christian beliefs. Spiritual forces, whether good or evil, are considered to have an influence on people's lives, well-being, and social relations. The Holy Spirit plays a fundamental role in the theology of many of these churches. The origins of this development were strongly influenced by the Pentecostal revival in North America at the beginning of the twentieth century (Anderson 2000). The African Initiated Churches of the second wave are often called Spiritual or Indigenous Churches. Self-designations are Aladura Churches in West Africa (Ositelu 2016), ${ }^{3}$ Roho/Akurinu in East Africa (Gichimu 2016), and Zionist/ Apostolic Churches in Southern Africa (Anderson 2000). Frequent characteristics are adult baptism by full immersion, strict moral codes, strict normative behavioural ethics based on literal bible hermeneutics, the importance of sanctified objects, and (often white) liturgical gowns worn by believers. Until today, the Spiritual Churches have particularly attracted the socially marginalised, but have long established themselves in all strata of society, particularly in Southern Africa. In West Africa they have increasingly faded in a general move towards African Pentecostal-Charismatic Churches (Meyer 2004).

African Pentecostal-Charismatic Churches are the third wave of African Initiated Christianity. They are closely related to the global Pentecostal movement, but are nonetheless considered an indigenous religious movement (Asamoah-Gyadu, Chapter 2, this volume; Padwick and Lubaale 2011). More so than the African Initiated Churches of the second wave, PentecostalCharismatic Churches generally distance themselves from African traditional belief systems and culture. Nonetheless, like the churches of the second wave, 


\section{Philipp Öhlmann et al.}

2015; Asamoah-Gyadu, Chapter 2, this volume; Padwick and Lubaale 2011; Pobee and Ositelu 1998) - even though marked differences in the churches' positioning towards African traditional religions exist.

The utility of any categorisation and conceptual framework depends on the object of investigation. With respect to the study of African Initiated Churches and sustainable development, the definition outlined above proves particularly fertile for the following four reasons.

First, because of their historical, institutional, and cosmological rootedness in Africa, the churches subsumed here as African Initiated Churches are not yet partners of development cooperation on a wider scale. ${ }^{4}$ In this, there is a marked difference to Mission Initiated Churches, which have implemented development projects with international funding for decades. African Initiated Churches implement manifold development-related activities as well, but the vast majority has no partnerships with international religious or official development agencies (Öhlmann, Frost, and Gräb 2016).

Second, from an institutional point of view, which is highly relevant in the study of religious communities' contributions and sustainable development, categorisations based on theological considerations might prove less useful. As we pointed out elsewhere, small Spiritual Churches, for example, might have more in common with small Pentecostal Churches than with a large Spiritual Church with millions of members like the Zion Christian Church (Öhlmann, Frost, and Gräb 2016). In terms of its structure, the Zion Christian Church might be more comparable with other transnational churches of similar size, like the Redeemed Christian Church of God, which is Pentecostal-Charismatic. An a priori differentiation between Spiritual Churches and Pentecostal Churches would obscure these similarities.

Third, the distinction between the Spiritual Churches and the Pentecostal Churches is not always clear-cut (Meyer 2004). Some churches consider themselves both, a Spiritual Church and Pentecostal. Examples are the Church of the Lord (Aladura) Worldwide with headquarters in Nigeria (Ositelu 2016, Chapter 11, this volume), Gilgal Bible Church in South Africa or the African Independent Pentecostal Church of Africa in Kenya. Other churches have crossed classificational boundaries: the Redeemed Christian Church of God, one of the largest Pentecostal-Charismatic Churches in Nigeria started out as a Spiritual Church and only later developed its Pentecostal-Charismatic profile (Adedibu, Chapter 8, this volume; Adeboye, Chapter 7, this volume).

Fourth, the OAIC, the largest umbrella body of African Initiated Churches, includes both African Independent as well as African Pentecostal Churches (Gichimu 2016; Padwick and Lubaale 2011).

\section{Approaching sustainable development: potentials and perspectives of African Initiated Christianity}

With respect to development, the Sustainable Development Goals (SDGs) form a central frame of reference, as outlined in the United Nations 2030 Agenda for 
Sustainable Development (United Nations 2015). Their 17 goals and 169 targets are internationally agreed on objectives for development policy and cooperation. The move from the preceding Millennium Development Goals to the SDGs marked a paradigm shift in international development policy. The SDGs brought together ecological objectives with economic, social, and political objectives and consolidated them in one multidimensional framework. Consequently, SDGs do not only apply to countries classified as 'developing countries' based on social or economic indicators. The milestone move from development to a framework of sustainable development implies that all countries are developing countries in at least part of the dimensions encompassed by the SDGs.

The notion of sustainable development was most prominently brought forward by the World Commission on Environment and Development in its 1987 report Our Common Future. It was defined as 'development that meets the needs of the present without compromising the ability of future generations to meet their own needs' (World Commission on Environment and Development 1987, 43). As we have highlighted elsewhere

$[T]$ he quintessence of the report was that economic and social development needs to take into account the ecological framework they operate in - and its limitations. In the original concept, sustainable development primarily referred to ecological sustainability. Consequently, in current development discourses, sustainable development is often used to describe a mode of development that takes into account ecological considerations and limitations of natural resources.

(Öhlmann, Frost, and Gräb forthcoming)

While the ecological dimension remains central in the Agenda 2030 for Sustainable Development as well, the Agenda broadened the notion of sustainable development by including economic, social, and political dimensions. When investigating the nexus of religion and sustainable development, as the contributions do, it is helpful to look at the basic meaning of sustainability:

In more general terms, sustainability refers to 'the ability to be maintained at a certain rate or level' (Oxford Dictionary 2017). Sustainable development interventions, hence, are such development programs or projects that produce sustained - i.e. lasting - changes beyond any given project lifetime. Ecological sustainability is a special case of sustainability: lasting change can only be generated if long-term ecological limitations are respected. Both notions have in common that they require a transformation of mind sets, values and knowledge. Ecological sustainability depends on a culture of sustainable use of natural resources. Similarly, the broader notion of sustainability depends on changes in people's consciousness, which result in different actions.

(Öhlmann, Frost, and Gräb forthcoming) 
Hence, the notion of development underlying the concept of the volume is deliberately wide and multidimensional, covering economic (e.g. Taru, Chapter 19, this volume), social (e.g. Akindolie, Chapter 10, this volume; Ouedraogo, Chapter 16, this volume), ecological (e.g. Werner, Chapter 3, this volume), and political (e.g. Asamoah-Gyadu, Chapter 2, this volume; Swart, Chapter 4, this volume) dimensions of sustainable development and accommodating for multiple and contextual notions and ideas of developments, as processes of sustained change.

With respect to African Initiated Churches and sustainable development, this volume and the research initiative in the framework of which it materialised, adopt a potentials-oriented approach. It highlights possible contributions of African Initiated Churches in the promotion of sustainable development in various contexts. Considering that African Initiated Churches are not yet recognised as development actors (Öhlmann, Frost, and Gräb 2016), it seems fitting to take this perspective. This is not to idealise African Initiated Churches in any way, or to imply that many of the potentials identified do not also exist in other churches and other religious communities. We acknowledge that there are problematic aspects in African Initiated Churches as in other churches and religious communities. Moreover, in light of the enormous size and the heterogeneity of the movement it is likely that cases of lack of transparency and accountability, personal enrichment or abuse of power can be found - such as the drastic examples documented in the South African context of pastors asking their members to drink petrol or to eat grass (CRL Rights Commission 2017; Kgatle 2017). Moreover, it should be clear that not all African Initiated Churches contribute to sustainable development. Nor do these churches contribute to all dimensions of sustainable development in the same way. Providing a differentiated perspective on the manifold relationships of African Initiated Churches with sustainable development is precisely the aim of this volume.

In the following, we identify six central themes that highlight the potential of African Initiated Churches with respect to sustainable development. We draw on the existing literature, our own field research in the context of the abovementioned project, and the contributions in this volume.

\section{Demographic significance}

First, African Initiated Churches are marked by highly dynamic development. They are among the largest and fastest-growing religious communities in many African contexts. In many countries on the continent, they represent substantial parts of the population and their networks reach even remote areas. To promote sustainable development among socially and economically marginalised parts of the population in rural and socially deprived areas, these networks constitute a pivotal resource. Moreover, their demographic significance relates to their contextuality. With respect to a "'recentring" of development' (BowersDu Toit, Chapter 21, this volume) this positions them ideally to include the 


\section{Members of African Initiated Churches as percentage of total Christian population in selected countries}

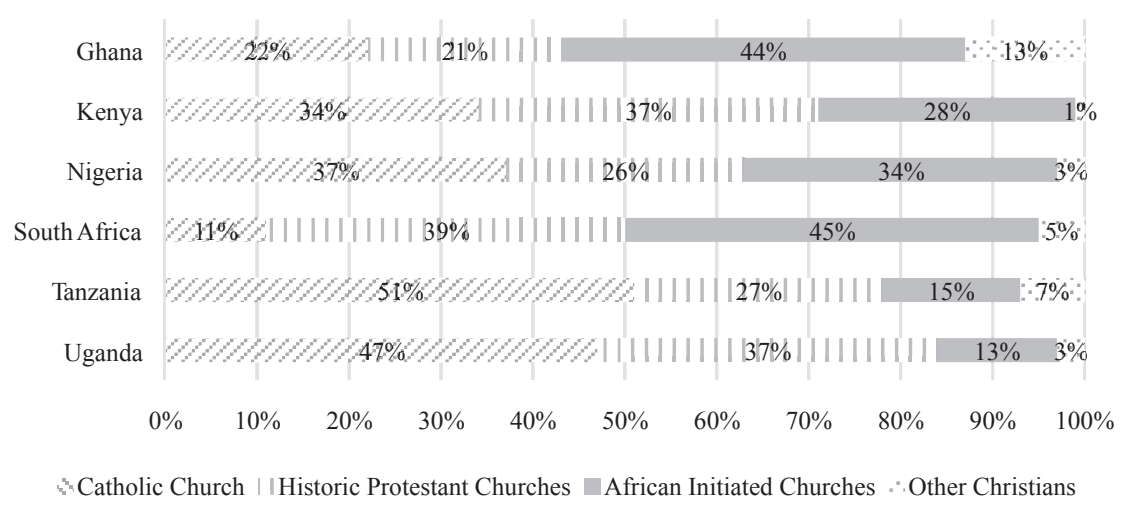

Figure 1.2 Membership of African Initiated Churches.

Note

Ghana: Population: 26 million (2012), 69\% Christians, Source: Ghana Living Standards Survey (Round 6), 2012; Kenya: Population: 41 million (2010), 88\% Christians, Source: Pew Forum, 2010; Nigeria: Population: 159 million (2010), 46\% Christians, Source: Pew Forum, 2010; South Africa: Population: 51 million (2010), 87\% Christians, Source: Pew Forum, 2010; Tanzania: Population: 45 million (2010), 61\% Christians, Source: Pew-Forum, 2010; Uganda: Population: 39 million (2014), 85\% Christians, Source: National Population and Housing Census, 2014. Exact membership figures of African Initiated Churches are not available. In some African countries, official censuses do not include religious affiliation (such as Nigeria and Tanzania) or do not differentiate between different Christian confessions. Hence, we draw on the Pew Forum on Religion and Public Life's 2010 representative survey 'Tolerance and Tension: Islam and Christianity in Sub-Saharan Africa', which covered 19 African countries. The figures presented cannot be taken at face value. African Christianity is highly dynamic and substantial shifts can occur within relatively short periods of time. Moreover, in many cases members of the Catholic or historic Protestant Churches are at the same time affiliated with African Initiated Churches, but do not appear as such in official statistics. Because of a lower degree of institutionalisation, particularly among the thousands of smaller African Initiated Churches, official figures have a tendency to underestimate the relevance of these churches.

views on desirable developments held by the local populations. Figure 1.2 provides an overview of the relevance of African Initiated Churches in selected African countries.

\section{Development activities}

Second, African Initiated Churches are actively engaged in improving conditions of life in their local contexts and societies, as many of the contributions in this volume as well as our own research highlight (Abdulsalami, Chapter 6, this volume; Akindolie, Chapter 10, this volume; Öhlmann, Frost, and Gräb 2016; Ositelu, Chapter 11, this volume; Padwick and Lubaale 2011). They do so with immense commitment and largely without outside funding. Even small 


\section{Philipp Öhlmann et al.}

churches implement activities that contribute towards sustainable development as outlined in the SDGs, be it through HIV/AIDS awareness raising, offering scholarships for students, entrepreneurship workshops or youth empowerment (see e.g. in this volume: Ajibade, Chapter 9; Akindolie, Chapter 10; Dah, Chapter 17; Gukurume, Chapter 18; Owusu-Ansah and Adjei-Acquah, Chapter 14; Taru, Chapter 19). Many churches establish schools, training centres, clinics, and hospitals (see e.g. in this volume: Adeboye, Chapter 7; Anim, Chapter 13; Onyinah, Chapter 12; Ouedraogo, Chapter 16; Owusu-Ansah and Adjei-Acquah, Chapter 14). OAIC, jointly with its member churches, implements a decentralised livelihoods programme focused on agriculture in East Africa. Larger African Initiated Churches found universities, offer micro insurance or even finance public infrastructure (see e.g. in this volume: Adeboye, Chapter 7; Adedibu, Chapter 8; Anim, Chapter 13; Onyinah, Chapter 12; Owusu-Ansah and Adjei-Acquah, Chapter 14). Moreover, at different political levels African Initiated Churches act in the interest of their members (Bompani 2008) and speak out against corruption and misuse of power (see Ajibade, Chapter 9, this volume; Asamoah-Gyadu, Chapter 2, this volume; Lekganyane 2016). Because of their institutional and financial independence, their agendas are less likely to be biased by donor interests.

\section{African solutions}

Third, African Initiated Churches stand for African solutions. They are actors embedded in the local context. In large parts, they are as a grass roots movement (Swart, Chapter 4, this volume; Bowers-Du Toit, Chapter 20, this volume). Contrary to NGOs depending on external funding and development experts from the global North, they constitute durable autochthonous social and institutional structures. Hence, in light of their independence and their contextuality, they are well positioned to achieve 'development [that] is people-driven, relying on the potential of African people', as stipulated in the African Union's Agenda 2063 (African Union 2015, 8). This is particularly relevant in contexts where government structures are weak and unreliable. Development-related activities implemented by contextually embedded religious communities such as African Initiated Churches increase ownership by the local population as well as transparency and accountability (Ouedraogo, Chapter 16, this volume; van Zyl, Chapter 20, this volume), as Nigerian Bishop and International Chairman of OAIC Daniel Okoh highlights:

People from Sub-Saharan Africa ... are highly religious, and anything that touches the religion of the people, they take it very seriously. And because of our colonial history, there is a way that people look at secular things.... They look at it as government and government is still seen as something that is very far away. But if it is religion, people take it to heart. And so, when you are talking about bringing the spiritual and the ... the social, it is important because, it is only by doing that, that you can actually engage the 
active participation of the people. And the people would come into it and say, 'this thing, God is in this thing, you must be very, very careful'. That is how you can get something positive in transparency, in accountability and all that, because of the spiritual aspect.... So, for Africa, because of the religious nature, you'll always find a way of using it to get the ... commitment of the people to the project, whatever it is. If it is water, it must be explained spiritually. If it is [an] agricultural project, it must be explained spiritually.... Honestly, if you don't do that, you will lose it.

(interview Daniel Okoh 2017)

\section{Empowerment and agency}

Fourth, African Initiated Churches seem to be conducive to economic initiative in the market economy. The theology of many African Initiated Churches is directed towards the liberation of the person from poverty. The Christian faith and the power of the Holy Spirit find their expression in the believers' material life. This sets free motivational forces, shapes new subjectivities, and fundamentally affirms the individual's agency (Dah, Chapter 17, this volume; Gukurume, Chapter 18, this volume; Maxwell 2005; OwusuAnsah and Adjei-Acquah, Chapter 14, this volume; Ruele 2016; Taru, Chapter 19, this volume; Togarasei 2016). Togarasei (2016) emphasises the relationship of African prosperity theology with traditional African notions on the connection between the divine and physical well-being and material prosperity. This is facilitated by what we have described above as the key characteristics contextuality and spiritual worldview. Moreover, Freeman describes a parallel between African Pentecostal-Charismatic Churches and Max Weber's Protestant Ethic. ${ }^{5}$

It is a form of Protestantism that not only fits with African sensibilities, but also stimulates a transformation of behaviour that can lead to success, or at least upward mobility, in the contemporary neoliberal economy. It motivates new behaviours and renders them moral. It is the notion that 'God wants you to have abundance' and that this is the divine plan that motivates these new behaviours, not an anxious quest to find evidence of one's election for salvation in the next world. Nevertheless, the consequences are the same: hard work, saving and a limitation on certain types of consumption.

(Freeman 2012b, 20)

Nearly four decades ago, Turner similarly highlighted this with respect to African Independent Churches:

[A]ttitudes pervade many of the independent churches, which exhibit a loose parallel to the Protestant work ethic. People do tend to prosper when they join these groups, not only because of moral reform, health 


\section{Philipp Öhlmann et al.}

improvement, less wasteful spending practices and regular habits built round the 7-day week programme of their church, but also because of a belief that they now have access to the power of the Spirit made available through these churches, their founders and practices, and through the Bible. This encourages confidence, initiative, perseverance, adaptability to the changing modem situation and freedom from distraction through political or other hysterias.

(Turner 1980, 528-529)

Promotion of business and entrepreneurship plays an important role for many African Initiated Churches. In many African Pentecostal Churches, prosperity gospel is not only preached from the pulpit, but is complemented by the active promotion of empowerment and business initiatives (Freeman 2012b). Churches offer entrepreneurship trainings and support business start-ups of their members with finances and expertise (Gukurume, Chapter 18, this volume; Taru, Chapter 19, this volume). While this is particularly important in African Pentecostal-Charismatic Churches, similar tendencies have been documented in other realms of the African Initiated Church movement as well (Öhlmann, Frost, and Gräb 2016; Turner 1980). Moreover, education is almost universally considered the key to personal success and sustained development. One key result from our own research, encompassing individual interviews and focus group discussions of African Initiated Church leaders, is that SDG 4: Quality Education is nearly unanimously rated as one of the most important development goals. Several church leaders underlined that 'development starts with education', because all other forms of development would follow from it (interview Daniel Oppong, 2017). As Rev. John Mahero, General Secretary of the African Divine Church in Kenya, illustrates: '[E]ducation is a key to development, without education, you can't develop. You develop the heart, the mind and the whole body. First here [pointing to his head], then the heart, and the whole body' (interview John Mahero, 2018). The importance of education in African Initiated Churches is inter alia highlighted in the contributions by Adeboye (Chapter 7), Adedibu (Chapter 8), Owusu-Ansah and Adjei-Acquah (Chapter 14), Ouedraogo (Chapter 16), and Gukurume (Chapter 18).

\section{Transformation}

Fifth, African Initiated Churches can be considered as agents of social change and individual transformation (see e.g. in this volume: Adedibu, Chapter 8; Adeboye, Chapter 7; Asamoah-Gyadu, Chapter 2; Gukurume, Chapter 18; Taru, Chapter 19). Due to their consideration of 'African sensibilities' (Freeman 2012b, 20; cf. Asamoah-Gyadu 2015) and their interwovenness with an African spiritual worldview, African Initiated Churches have a high 'transformative potential', i.e. 'the capacity to legitimize, in religious or ideological terms, the development of new motivations, activities, and institutions' (Eisenstadt 1968, 
10). This can be illustrated with the example of the Zion Christian Church, the largest church in Southern Africa. In his Easter sermon, the church's bishop, Barnabas E. Lekganyane, called upon believers to

Be in a state of readiness. Make sure you are registered to vote in your area. Prepare yourselves to go elect your local leaders who will represent your aspirations. Even those who will be asking your vote should remember that leadership is about service to the community. I know that some of the candidates will be coming to you for the first and last time ever even if they win. We can only hope and pray that they will not forget about you once you've elected them. When talking about leadership, Henry A. Kissinger cautions thus 'The task of the leader is to get his people from where they are to where they have not been', adding that, ' $90 \%$ of the politicians give the other $10 \%$ a bad reputation'. Remember that every community deserves the leadership they elect. So you've got the power to determine who leads you. Utilize that power to choose correctly and to empower your people.

(Lekganyane 2016)

Such encouragement to contribute to the democratic process by voting in the upcoming municipal elections is likely to have substantial impact on the church's millions of members precisely because of ZCC's rootedness in African belief systems and the church's significance in the religious dimension of people's lives. Asamoah-Gyadu (Chapter 2) describes a similar type of encouragement for civic engagement in the Ghanaian context: International Central Gospel Church leader Mensa Otabil prior to the 2016 elections encouraged his congregants to exercise their right to vote in a sermon entitled 'Your Vote'. Similar arguments are also brought forward by Ajibade (Chapter 9), while Adeboye (Chapter 7) is more sceptical regarding the Nigerian context. The Church of Pentecost deliberately engages with the public sphere, e.g. by hosting Christian leadership conferences for politicians (Onyinah, Chapter 12, this volume).

The transformative potential is also visible at the individual level. African Initiated Churches aim at a transformation of the whole person and to enable each person and the community to live a good life. Elijah Daramola, at that time Pastor in Charge of the Southern Africa Region of the RCCG pointedly stated:

You need to change the whole person. Because it will be a waste of time and money if you train people without their lives being changed ... Our goal must be made clear. Is it in just impacting people and leave them living anyhow? Or is it impacting people and mak[ing] live peaceful? If we have this agreement, we will flow together. But otherwise [our] work will not be a blessing to others.

(interview Elijah Daramola 2016) 
It is the interrelation and interaction of spirituality and socioeconomic development that goes along with a mutual openness to local culture that breaks the ground for transformation and sustainable development. African Initiated Christianity creates spaces that make (ecologically, socially, and economically) sustainable development also culturally sustainable (cf. Meireis and Rippl 2019), providing for an 'embeddedness in local cultural frameworks (essentially including all forms of religious knowledge), which produces continuously maintained processes of change' (Öhlmann, Frost, and Gräb forthcoming).

\section{Decolonising development}

Sixth, African Initiated Churches have the potential to make key contributions to a decolonisation of development. In his inaugural lecture for the chair of development policy and postcolonial studies at University of Kassel, Aram Ziai highlighted two desiderata regarding the decolonisation of development: first, taking into account notions of development other than the dominant ones undergirded by 'western ... hegemonial models of the organisation of economy, politics and knowledge' and second the 'dismantling of hierarchies between development experts and the people concerned' (Ziai 2017, authors' translation; cf. Bowers-Du Toit, Chapter 21, this volume; van Zyl, Chapter 20, this volume). In a related vein, Mayer (2019) draws on postcolonial theory to develop three criteria for postcoloniality with reference to African Initiated Churches. These criteria are, first, 'resistance and indigenization' (building on Varela, María do Mar Castro Varela, and Dhawan 2015; Heuser 2016), second, referring to Chakrabarty 2008, 'decentralization and empowerment', and, third, the 'dismantling of Eurocentric patterns of thought' (relating to Becker 2018; Böttigheimer 2016; Heaney 2015; Said 1978). Essentially, this takes up and relates to the key themes of independence, contextuality, and spiritual world view introduced above. It hence emerges that these central characteristics can be directly transposed as conceptual categories delineating their contributions to decolonising concepts and practices of development.

Because of their institutional and financial independence, they are much less subject to the influence of donor agendas than donor-funded NGOs or religious development organisations. Hence, African Initiated Churches have the potential to contribute to the decolonisation of development by enabling agency of people and communities (Bowers-Du Toit, Chapter 21, this volume). As independent actors, African Initiated Churches can thus promote development based on local agendas, agency, and ownership. In their independence from outside funding also lies great potential for internal accountability and transparency, as inter alia the case of the Church of Pentecost illustrates (Anim, Chapter 13, this volume; Onyinah, Chapter 12, this volume; see also OwusuAnsah and Adjei-Acquah's chapter on Perez Chapel International, Chapter 14, this volume). Moreover, the ends of their activities have the potential to be more focused on the priorities of the respective local communities. This relates to the idea of 'development from below' (Swart, Chapter 4, this volume), that 
development needs to not only be driven by international organisations and governments, but by people and organisations at the micro and meso levels of society. As Swart highlights, various authors argue that African Initiated Churches bear great potential for a 'development from below', a development driven by the local people. Also in this collection many contributions show how this 'development from below' is put into practice and even trickles upward to wider levels of society - for example through the provision of schools, hospitals, universities, and the engagement with political circles (see e.g. in this volume: Adeboye, Chapter 7; Anim, Chapter 13; Asamoah-Gyadu, Chapter 2; Onyinah, Chapter 12; Owusu-Ansah and Adjei-Acquah, Chapter 14).

Moreover, due to their contextuality their actions have the potential to be more aligned to contextual notions of development informed by contextual culture and religion. African Initiated Churches are embedded in their respective context. Beyond being independent, they are thus able to make reference to, navigate in, and incorporate local social structures as well as cultural and religious worldviews and cosmologies, for example Ubuntu (Bowers-Du Toit, Chapter 21; Gichimu, Chapter 5, this volume) or Ilosiwaju/Omoluabi (Adeboye, Chapter 7, this volume). Moreover, they can be seen not only as representatives of the local communities, but rather as focal point of people's action itself, as Swart (Chapter 4, this volume) points out with reference to Sanyal and Korten:

[W] hen considered in terms of NGO organisational theory, AICs could according to this appreciation as development from below agents even be seen as surpassing NGOs' role as 'third-party' organisations that operate on behalf of people's interests.... Instead, they could be seen as taking on the role of 'first-party' organisations that embody people's direct participation.

But perhaps the greatest potential for decolonising development is related to the ideological level. The spiritual worldview of African Initiated Churches fundamentally challenges dominant, secular notions of sustainable development (Bowers-Du Toit, Chapter 21, this volume; Öhlmann et al. 2018). ${ }^{6}$ As we have pointed out with reference to Freeman (2012b); Gifford (2015); Masondo (2013); and Oosthuizen (1988): 'AICs are embedded in a specific discursive, material and practical context. They are rooted in a worldview in which the spiritual, social and physical spheres constitute various layers of the same reality' (Öhlmann et al. 2018, 9), and in which 'religious or spiritual, moral and cultural dimensions ... are inseparable from other spheres of society' (Adogame 2016, 3). Freeman (2012b, 9) notes with respect to African Pentecostal Churches (the statement can be generalised to African Initiated Christianity): '[T]hey maintain a magico-religious worldview in sharp contrast to mainstream development's rational secularism'. Religious dimensions are essential and inseparable parts of notions of development:

It becomes clear that from the perspective of African Initiated Churches and the communities they are embedded in, it is vital to note that 
spirituality is an essential part of a good life and hence a fundamental dimension in development.

(Öhlmann et al. 2018, 9)

This can be illustrated with quotes from church leaders interviewed in our own field research. Elijah Daramola, already quoted above, expressed this in the pointed statement 'Spiritual development is part of development. A good life includes spirituality' (interview Elijah Daramola 2016). Notions of a good and fulfilled life extend beyond material and social aspects, as Elias Mashabela, bishop of Bophelong Bible Church in Polokwane, South Africa, explained:

The NGOs are taking care of people, but they do not take care of the spiritual part of the human being. So, we are taking care of the people ... but we go beyond. We also look at the spiritual well-being of the persons ... We run similar programmes, but we do more by adding the spiritual level.

(interview Elias Mashabela 2016)

A church leader from Nigeria (wishing to remain anonymous) declares these dimensions inseparable: 'When it comes to development, we have spiritual development, we have physical and social development. So, so you cannot separate any of the development from each other, because the church provides both the social and the spiritual development' (interview 2017/N/14).

In the field of tension between (western-dominated) secular concepts of development and (African) spiritual worldviews, decolonising concepts and practices of development inter alia mean bringing forward alternative notions of development, which adequately take into account local religious knowledge and cosmologies and incorporate cultural and spiritual dimensions. This is the primary contribution African Initiated Churches can make to the decolonisation of development.

\section{Approaching the book: outline of this volume}

Written predominantly by scholars from the African continent, the chapters in this volume illuminate potentials and perspectives of African Initiated Christianity with respect to different notions and dimensions of sustainable development. The purely academic perspectives in this volume are complemented with essays by renowned church leaders themselves, marked as distinguished church leader contributions in the respective part of the book. These essays deliberately include personal views, experiences, and opinions and provide forms of knowledge production that by their very nature pure research articles cannot provide.

The book is structured along regional lines. In Part I, the book offers overarching perspectives on different themes applying to the African Initiated Church movement across contexts (Asamoah-Gyadu, Chapter 2; Werner, Chapter 3; Gichimu, Chapter 5) or reflect on the academic discourse on African Initiated Christianity and development (Swart, Chapter 4). Part II provides 
perspectives on and from selected African contexts, starting with Nigeria (Abdulsalami, Chapter 6; Adeboye, Chapter 7; Adedibu, Chapter 8; Ajibade, Chapter 9; Akindolie, Chapter 10; Ositelu, Chapter 11). Part III is on Ghana (Onyinah, Chapter 12; Anim, Chapter 13; Owusu-Ansah and Adjei-Acquah, Chapter 14; Oduro, Chapter 15); Part IV is on Burkina Faso (Ouedraogo, Chapter 16; Dah, Chapter 17). Moving to Southern Africa, Parts V and VI focus on Zimbabwe (Gukurume, Chapter 18; Taru, Chapter 19) and South Africa (van Zyl, Chapter 20; Bowers-Du Toit, Chapter 21).

In terms of their scope on African Initiated Christianity, several chapters deal with the movement as a whole (Asamoah-Gyadu, Chapter 2; Werner, Chapter 3; Swart, Chapter 4; Gichimu, Chapter 5; Abdulsalami, Chapter 6). Others shine a spotlight on specific churches or branches of the African Initiated Church movement. The majority of the chapters focus on PentecostalCharismatic Churches, the most dynamic expression of African Initiated Christianity in many African contexts (Adeboye, Chapter 7; Adedibu, Chapter 8; Ajibade, Chapter 9; Onyinah, Chapter 12; Anim, Chapter 13; Owusu-Ansah and Adjei-Acquah, Chapter 14; Gukurume, Chapter 18; Taru, Chapter 19). The contributions on Burkina Faso (Ouedraogo, Chapter 16; Dah, Chapter 17) offer perspectives on Evangelical Churches. African Independent Churches are the frame of reference for Oduro (Chapter 15), van Zyl (Chapter 20), and Bowers-Du Toit (Chapter 21), while Akindolie (Chapter 10) and Ositelu (Chapter 11) provide insights on the respective Nigerian local expression, Aladura Churches.

With respect to sustainable development, some of the chapters focus on a subset of dimensions of the SDGs (e.g. Werner, Chapter 3, on ecology; Abdulsalami, Chapter 6 and Ouedraogo, Chapter 16, on gender), while others take a more comprehensive perspective. Most of the chapters raise fundamental issues relevant for the entire discussion on African Initiated Christianity and sustainable development beyond the immediate regional or case study scope. In particular, several of the chapters advance important points regarding notions of sustainable development and the decolonisation of development (inter alia Asamoah-Gyadu, Chapter 2; Swart, Chapter 4; Adeboye, Chapter 7; Ajibade, Chapter 9; Onyinah, Chapter 12; Owusu-Ansah and Adjei-Acquah, Chapter 14; Dah, Chapter 17; Taru, Chapter 19; van Zyl, Chapter 20; Bowers-Du Toit, Chapter 21.

\section{Chapter outlines}

J. Kwabena Asamoah-Gyadu (Chapter 2) refers to the spiritual worldview of African Initiated Christianity by describing them as African 'pneumatic movements'. He traces their history from the early-twentieth century onwards and highlights their close relationship with the social and cultural environment (contextuality). Asamoh-Gyadu argues that what is most relevant for development in African Independent Churches 'is the stress on personal transformation $\ldots$ and its implications for ethics and morality on societal development'. With respect to the Pentecostals, 'Paradigms of Prosperity' and 'Hermeneutics of 
Black Empowerment' emerge as key themes. Asamoah-Gyadu makes out a constructive engagement with the state: in the case of the Independents, their 'contribution to the emergence of pro-political independence [and] the ability ... to transcend "the limitations of language, tribe, and region" [Turner 1979] to create a wider community of people' and in the case of the Pentecostals a strive for 'responsible citizenship' and 'social engagement'.

In Chapter 3 Dietrich Werner reflects on the potential of African Initiated Christianity for rediscovering traditional African values. African Pentecostal and Independent Churches, the author points out, rethink Christianity in a non-western way (contextuality). This leads to a decolonial concept of development, which means 'development from below' but also includes ecological sustainability. He indicates that these churches bear great potential to reinforce ecological responsibilities grounded in their theologies and practices. African eco-theologies, according to Werner, display a closer relationship between nature and humankind then other branches of Christianity. African Initiated Churches articulate important elements of such an African eco-theology. He conjectures that they can lead the way out of the ecological dilemmas presented by western-dominated development concepts.

Ignatius Swart (Chapter 4) takes a meta perspective by investigating the hypothesis emerging from the literature that African Initiated Churches are actors of 'development from below'. This is a type of 'grassroots development' grounded in the micro level of society and particularly enabling ownership, agency and local agenda-setting - essentially drawing on the characteristics of independence and contextuality. Swart scrutinises this hypothesis by analysing what different authors understand as 'development from below', identifying five dimensions: (1) 'development from below as a de-secularised catchphrase'; (2) as a 'counterpoint to development from above'; (3) the political role of African Initiated Churches; (4) personal empowerment and the economic realm; and (5) social capital. Swart proposes these dimensions as conceptual frameworks for further research on African Initiated Churches and development and highlights possible points of departure.

John Njeru Gichimu (Chapter 5) outlines African Initiated Churches' theology in relation to their contextuality, finding its expressions in 'localism' and 'communalism'. He highlights key elements of their beliefs and practices from an East African perspective (which in many points is generalisable to the whole sub-Saharan region). Moreover, Gichimu focuses on the theology of African Initiated Churches. He draws on the OAIC's definition of theology in the context of African Initiated Christianity as 'people making sense of God in the midst of their histories, cultures, worldviews and contemporary struggles for survival'. The author describes how theological training in African Initiated Churches has evolved and is continuing to evolve - and how OAIC contributes to facilitating these processes.

Drawing on her personal experience as founder of an African Independent Church, Atinuke Abdulsalami (Chapter 6) focuses on the role of women in African Initiated Christianity. In her distinguished church leader essay, she criti- 
cises that while gender equality is discussed at different levels of society, especially in African Pentecostal Churches in Nigeria women are still 'in the closet of "to be seen, not heard"'. Nevertheless, she observes a growing movement of women fellowships in African Pentecostal Churches through which women have not only shown their ability to lead, but also 'impacted the lives of women in and outside of the churches'. The author describes hindrances women and women leaders face in the church and gives recommendations for their support and empowerment. Through her own achievements, she exemplifies what women are able to do for the church and the wider community if they have the possibility to lead instead of being 'limited by some men's limited imagination'.

Olufunke Adeboye (Chapter 7) focuses on the Redeemed Christian Church of God (RCCG). As one of the largest Charismatic Churches in the world, it is in itself a materialisation of empowerment, confidence, and independence. The author analyses RCCG's social service work in Nigeria, epitomised in the church's recent rebranding of these services as 'Christian Social Responsibility'. While RCCG's social service engagement is extensive - inter alia covering health, education, and economic empowerment - Adeboye argues that one 'critical element missing in the policy structure of RCCG's [Christian Social Responsibility] is a commitment to social justice and social action'. The author grounds her analysis of RCCG in discussions of the history of Christian social work in Africa, the Pentecostal movement in Nigeria, and Christian as well as Yoruba cultural notions of development, thereby relating to the characteristic of spiritual worldview.

To highlight the contribution of Pentecostal Churches to development Babatunde Adedibu's chapter (8) also draws on the example of the Redeemed Christian Church of God. Starting with a critical analysis of Gifford's book Christianity, Development, and Modernity in Africa (2016), the author argues that 'in the last six decades, Pentecostal Churches have responded to some of the criticism of their tradition and have made an impressive impact in socioeconomic, political and educational initiatives in Africa and diaspora'. Adedibu demonstrates the postcolonial character of the spiritually grounded 'development from below' model, enabling people to maximise their potentials to 'live life to the fullest, based on dignity, equality, and fulfilment' and undergirding the church's contribution to social capital building, healthcare, and education.

Mobolaji Oyebisi Ajibade (Chapter 9) explains that in Nigeria Pentecostals are beginning to contribute to decolonising concepts and practices of development by participating actively in civil society. They embrace forms of political participation and social action they had formerly rejected. The author asserts that Pentecostals follow religious principles that have direct effects on economic behaviour. They lend religious and ideological legitimacy to new motivations, activities, and institutions. The impact of Pentecostalism on decolonising concepts of development, the author shows, comes not so much from its theological doctrine, but from its flexibility and its capacity to give expression to new social practices in the defining moments of a society in transition. 


\section{Philipp Öhlmann et al.}

Akinwumi Akindolie's focus is on Aladura Churches in Nigeria (Chapter 10), which, despite the gravity shift from Independent to Pentecostal Churches in West Africa (Meyer 2004), constitute a large and dynamic branch of African Initiated Christianity in the country. The author argues that because of the emphasis of an indigenous spiritual worldview, they have been predominantly seen as churches that primarily cater for people's spiritual needs. However, Akindolie shows that regardless of challenges such as financial and human resource limitations, they move beyond the spiritual dimensions. They engage in various social service and human development activities, inter alia in the fields of education and health, but also by encouraging civic engagement and doing political advocacy work.

In his distinguished church leader essay Rufus Ositelu (Chapter 11), one of the most prominent representatives of the Aladura Church movement, provides an overview of the theology of one of the largest and oldest Aladura Churches, the Church of the Lord (Prayer Fellowship) Worldwide. According to its core tenets, the author highlights, the church is 'Pentecostal in Power', 'Biblical in Pattern', 'Evangelical in Mission', 'Prophetic in Ministry', 'Social in Responsibility', and 'Ecumenical in Outlook'. This illustrates the commonalities across the Independent and Pentecostal branches of African Initiated Christianity as well as the church's commitment to the material, social, and political dimensions of believers' lives and wider society.

The former chairman of the Ghanaian Church of Pentecost (CoP), Opoku Onyinah (Chapter 12) provides an in-depth account of the church's history, core beliefs, structures, and engagement in social services and the public sphere. The key theme in his distinguished church leader essay is independence, a principle clearly visible in the CoP's principles of self-sustainability and autonomy. This strongly relates to the notion of decolonialisation. The author portrays the church as a role model for transparency, accountability, and institutional good governance. As such, the church is increasingly active in the public sphere, through individual members as well as at the institutional level for example by hosting events 'for Christian politicians and chief executives with the aim to help them put into place good and godly governance practices and administration'.

Emmanuel Kwesi Anim (Chapter 13) presents the work of the Church of Pentecost as an example of the changing self-understanding of Pentecostal Churches and situates it within the wider context of different development models. While, as he points out, African Pentecostal Churches used to focus on the spiritual aspect of their work, they have become increasingly active in improving the social and physical lives of their members and the wider communities. The Church of Pentecost is an important development agent active in the fields of education, economy, and ecology. Due to its comprehensive engagement and its financial self-reliance (independence), the church exemplifies both the growing engagement of Pentecostal Churches as well as the 'bottomup' type of development Anim is advising.

Sylvia Owusu Ansah and Philip Adjei-Acquah (Chapter 14) critically engage with the notion of sustainable development in their chapter. The 
authors investigate the case of Perez Chapel International, a Ghanaian Pentecostal-Charismatic Church. They relate the church's beliefs and aims to notions of sustainable development, arguing that 'sustainable development and holistic development [... ] go together'. They also highlight the church's commitment, accountability, and independence. The focus of the chapter is on educational and youth empowerment activities, major areas of engagement of the church. Referring to the 'Youth Explosion Programme', the authors show how the church uses holistic notions of transformation to promote youth empowerment and agency - thereby demonstrating how the spiritual worldview contributes to success in the material realm.

The relationship of Mission Churches and African Independent Churches in Ghana is the topic of Thomas A. Oduro's distinguished church leader essay (Chapter 15). The author zooms in on Good News Theological Seminary, a theological training institution in which students from both church backgrounds study together on equal terms. Oduro traces the history of the seminary and illustrates how through strategic dialogue and engagement the leadership of the institution contributed to bridging gaps between two church families that, a few decades ago, had been marked by prejudice, distance, and mutual scepticism. Moreover, he points out how the seminary has contributed to theological education in Independent Churches, to the documentation of their history and the evolvement of their theology.

In his distinguished church leader essay, Philippe Ouedraogo (Chapter 16) highlights the contribution of African Initiated Christianity to education and female empowerment in Burkina Faso. From his analysis of the Assemblies of God Church and two religious organisations working in the Burkinabe education sector, an important lesson is the relevance and benefit of partnerships between faith communities and government institutions at local and national level. The author moreover highlights imperatives for development cooperation with religious communities: The expansion of partnerships with religious communities in the area of education and the need for the state and international development cooperation to support local, independent, and contextual actors in their work instead of bringing in international experts.

Ini Dorcas Dah's contribution (Chapter 17) refers to the case of Centre International d'Evangélisation/Mission Interiéure Africaine in Burkina Faso. The author draws on Myers's (2011) concept of 'transformational development' to undergird her analysis of the church's work. The denomination's development activities relate to education and training, child protection and welfare, women empowerment, and practices that protect and sustain the environment. Dah's results closely relate to the notion of decolonising development. A core element of the church's notion of sustainable development is the spiritual dimension (spiritual worldview). Moreover, development is not only oriented towards economic growth, but takes into consideration social and environmental dimensions. Sustainability, the author argues, is about empowering people to develop their own means of survival (independence) within their socioeconomic, political, and environmental contexts (contextuality) without causing threats to the future generations. 


\section{Philipp Öhlmann et al.}

Simbarashe Gukurume (Chapter 18) analyses how New Pentecostal Charismatic Churches (PCCs) in Zimbabwe contribute to shaping young people's futures. He explores the economic teachings of these churches and shows how they initiate new development concepts and practices in the postcolonial Zimbabwean context. Development, he argues, in light of his analysis of the diverse youth empowerment activities of PCCs, is no longer the prerogative of the state. Instead, new PCCs impact on the development of their members and the nation at large. They view it as their role to liberate their congregants and their country from poverty through a combination of spiritual technologies and concrete means of empowerment such as business trainings and empowerment workshops. Their teachings resonate strongly with African ontologies, sensibilities, and realities (spiritual worldview). In terms of notions of development, prosperity emerges as the key concept.

Prosperity is also a central theme in Josiah Taru's chapter (19) on the Zimbabwean context. In his in-depth analysis of a Pentecostal-Charismatic Church, he shows how in the midst of the precarities and insecurities of the run-down Zimbabwean economy, the church is able to promote its theology of prosperity at various levels: at the individual level by forming new subjectivities and motivations, at the social level by networks of social-capital resources and at the institutional level by providing entrepreneurship training and business support and a large-scale housing cooperative. In this, the chapter illustrates how agency is produced in African Initiated Christianity, thus enabling people amidst virtual state failure to take development into their own hands.

Taking a grassroots perspective in his distinguished church leader's essay, Danie C. van Zyl (Chapter 20) draws on his vast experience in working with African Initiated Churches in South Africa to highlight important desiderata for development cooperation. They are ex ante substantiated by the narration of three life journeys - two church leaders' and the author's own. In the same vein as, for example, the contributions by Ouedraogo (Chapter 16) and Taru (Chapter 19), van Zyl highlights that state-driven development efforts and international development cooperation need to take into account the individual and social dimensions. Development, in his view, is only sustainable if local ownership as well as mutual trust between all stakeholders are ensured and if the agenda is set by the local communities and individuals themselves.

Taking the ideas brought forward by van Zyl to a more conceptual level and tying together threads of thoughts from the preceding chapters, Nadine BowersDu Toit (Chapter 21) asks how African Independent Churches foster the decolonisation of development. In this her contribution challenges the very notion of development itself, which she sees as western, secular, and still influenced by its historical roots in modernisation theory. Informed by postcolonial theory, she highlights the Independent Churches' contributions at the ideological and the institutional levels. Bowers-Du Toit argues that African Independent Churches have the potential of redefining the notions of development in accordance with religion and local culture (contextuality and spiritual worldview). On the more pragmatic side, the contributions to decolonising 
development pointed out by the author relate to contextuality, independence, and 'development from below' (Swart, Chapter 4): empowering the people themselves to act and ensuring that the agenda is set by the local community.

\section{Notes}

Some of the arguments in this text have been previously made in the policy briefs "Was sind African Initiated Churches?' Kurzstellungnahme 02/2018 des Forschungsbereichs Religiöse Gemeinschaften und nachhaltige Entwicklung and 'Religion Matters - African Initiated Churches Matter!' Kurzstellungnahme 03/2018 des Forschungsbereichs Religiöse Gemeinschaften und nachhaltige Entwicklung as well as the article 'Afrikanische Freikirchen - Partner in der Entwicklungszusammenarbeit: Mit Gott zu mehr Wohlstand', Herder Korrespondenz 01/2019, 25-28. Much of the content of this chapter also entered into the report 'Potenziale der Zusammenarbeit mit African Initiated Churches für nachhaltige Entwicklung. Ergebniszusammenfassung des Forschungsprojekts und Handlungsempfehlungen für die deutsche Entwicklungspolitik', HumboldtUniversität zu Berlin, 2019.

1 Also Orthodox Churches, e.g. in Egypt and Ethiopia, are churches founded in Africa independently of modern-time missionary movements. However, with respect to their history and theology they are fundamentally different from the churches initiated in Africa in the nineteenth and twentieth centuries. Hence, they are not included in the definition of African Initiated Churches here. Similarly, the Dutch Reformed Church in South Africa and its split-offs such as the Nederduitsch Hervormde Kerk van Afrika are not considered part of African Initiated Christianity here due to their European provenance.

2 The term 'Ethiopian' stems from Psalm 68, verse 31 (KJV): 'Ethiopia shall soon stretch out her hands unto God' (Sundkler 1961, 39).

3 For an outline of Aladura theology, see Ositelu (Chapter 11, this volume).

4 There are some exceptions, such as the Redeemed Christian Church of God (Adeboye, Chapter 7, this volume; Adedibu, Chapter 8, this volume), whose social service arms receive international development funding. OAICs' development programmes are also financed with international funds, particularly from religious development organisations in Europe and North America.

5 This resonates well with Berger's similar argument regarding Latin American Pentecostalism (Berger 2010).

6 In this section we rely on arguments previously made in Öhlmann et al. (2018).

\section{References}

Acosta, Alberto. 2016. Buen Vivir: Vom Recht auf ein gutes Leben. München: Oekom.

Adogame, Afe. 2016. 'African Christianities and the politics of development from below.' HTS Theological Studies 72 (4). https://doi.org/10.4102/hts.v72i4.4065.

African Union. 2015. Agenda 2063. The Africa We Want. Addis Ababa: African Union Commission.

Anderson, Allan. 2000. Zion and Pentecost. The Spirituality and Experience of Pentecostal and Zionist/Apostolic Churches in South Africa. Pretoria: University of South Africa.

Anderson, Allan. 2001. African Reformation: African Initiated Christianity in the 20th Century. Trenton: Africa World Press.

Asamoah-Gyadu, J. Kwabena. 2005. African Charismatics: Current Developments within Independent Indigenous Pentecostalism in Ghana. Leiden, Boston: Brill. 


\section{Philipp Öhlmann et al.}

Asamoah-Gyadu, J. Kwabena. 2015. 'Pentecostalism and the Transformation of the African Christian Landscape.' In Pentecostalism in Africa: Presence and Impact of Pneumatic Christianity in Postcolonial Societies, edited by Martin Lindhardt, 100-114. Leiden: Brill.

Barro, Robert J., and Rachel M. McCleary. 2003. 'Religion and Economic Growth across Countries.' American Sociological Review 68: 760-781.

Basedau, Matthias, Simone Gobien, and Sebastian Prediger. 2018. 'The Multidimensional Effects of Religion on Socioeconomic Development: A Review of the Empirical Literature.' Journal of Economic Surveys 32 (4): 1106-33. https://doi. org/10.1111/joes.12250.

Beck, Sedefka V., and Sara J. Gundersen. 2016. 'A Gospel of Prosperity? An Analysis of the Relationship Between Religion and Earned Income in Ghana, the Most Religious Country in the World.' Journal for the Scientific Study of Religion 55 (1): 105-29. https:// doi.org/10.1111/jssr.12247.

Becker, Patrick. 2018. 'Zu einem integrativen Verständnis. Wahrheit, Wissenschaft und Weisheit im (post)modernen Diskurs.' In Wissenschaft - Wahrheit - Weisheit, edited by Ulrich Lüke and Hildegard Peters, 110-138. Freiburg: Herder.

Belshaw, Deryke, Robert Calderisi, and Chris Sugden, eds. 2001. Faith in Development: Partnership Between the World Bank and the Churches of Africa. Oxford: Regnum Books International.

Berger, Peter L. 2010. 'Max Weber is Alive and Well, and Living in Guatemala: The Protestant Ethic Today.' The Review of Faith $\mathcal{E}$ International Affairs 8 (4): 3-9. https:// doi.org/10.1080/15570274.2010.528964.

BMZ. 2016. Religious Communities as Partners for Development Cooperation: Strategy Paper. Bonn/Berlin: Bundesministerium für wirtschaftliche Zusammenarbeit und Entwicklung.

Bompani, Barbara. 2008. 'African Independent Churches in Post-Apartheid South Africa: New Political Interpretations.' Journal of Southern African Studies 34 (3): 665-677. https://doi.org/10.1080/03057070802259928.

Bompani, Barbara. 2010. 'Religion and Development from Below: Independent Christianity in South Africa.' Journal of Religion in Africa 40 (3): 307-330. https://doi. org/10.1163/157006610X525435.

Bompani, Barbara. 2019. 'Religion and Development: Tracing the Trajectories of an Evolving Sub-Discipline.' Progress in Development Studies 13 (1). https://doi. org/10.1177/1464993419829598.

Bornstein, Erica. 2005. The Spirit of Development: Protestant NGOs, Morality, and Economics in Zimbabwe. Stanford: Stanford University Press.

Böttigheimer, Christoph. 2016. 'Wahrheitsansprüche und christlicher Offenbarungsanspruch.' In Globalität und Katholizität. Weltkirchlichkeit unter den Bedingungen des 21 . Jahrhunderts, edited by Christoph Böttigheimer, 103-116. Freiburg: Herder.

Chakrabarty, Dipesh. 2008. Provincializing Europe: Postcolonial thought and historical difference. Princeton, NJ: Princeton University Press.

Clarke, Gerard, and Michael Jennings, eds. 2008. Development, Civil Society and Faith-Based Organizations: Bridging the Sacred and the Secular. Basingstoke: Palgrave Macmillan.

Cochrane, James. 2011. 'A Model of Integral Development. Assessing and Working with Religious Health Assets.' In Ter Haar 2011, 231-252.

CRL Rights Commission. 2017. Report of the Hearing on the Commercialisation of Religion and Abuse of People's Belief Systems. Johannesburg: Commission for the Promotion and Protection of the rights of Cultural, Religious and Linguistic Communities. 
Cross, Catherine, Gerhardus C. Oosthuizen, and Craig Clark. 1993. Out of the Wind. The African Independent Churches and Youth Urbanization in Metropolitan Natal. A Report Prepared for the Co-Operative Programme on the Youth. Durban.

Deneulin, Séverine, and Masooda Bano. 2009. Religion in Development: Rewriting the Secular Script. London: Zed.

Deneulin, Séverine, and Carole Rakodi. 2011. 'Revisiting Religion: Development Studies Thirty Years On.' World Development 39 (1): 45-54. https://doi.org/10.1016/j. worlddev.2010.05.007.

Dickow, Helga. 2012. Religion and Attitudes Towards Life in South Africa: Pentecostals, Charismatics and Reborns. Baden-Baden: Nomos.

Eisenstadt, Shmuel N. 1968. 'The Protestant Ethic Thesis in an Analytical and Comparative Framework.' In The Protestant Ethic and Modernization: A Comparative View, edited by Shmuel N. Eisenstadt, 3-45. New York, London: Basic Books.

Freeman, Dena, ed. 2012a. Pentecostalism and Development: Churches, NGOs and Social Change in Africa. Basingstoke: Palgrave Macmillan.

Freeman, Dena. 2012b. 'The Pentecostal Ethic and the Spirit of Development.' In Pentecostalism and Development: Churches, NGOs and Social Change in Africa, edited by Dena Freeman, 1-38. Basingstoke: Palgrave Macmillan.

Garner, Robert C. 2004. 'African Independent Churches and Economic Development in Edendale.' In Venter 2004b, 81-103.

Gichimu, John Njeru. 2016. 'History and Profile of OAIC.' In Phiri, Werner, Owino, and Kaunda 2016, 810-818.

Gifford, Paul. 2015. Christianity, Development and Modernity in Africa. London: Hurst.

Guiso, Luigi, Paola Sapienza, and Luigi Zingales. 2003. 'People's Opium? Religion and Economic Attitudes.' Journal of Monetary Economics 50: 225-282.

Heaney, Robert S. 2015. From Historical to Critical Post-Colonial Theology. The Contribution of John S. Mbiti and Jesse N. K. Mugambi. Eugene, Oregon: Pickwick Publications.

Heuser, Andreas. 2013. “"Refuse to Die in Poverty!” Armutsüberwindung und Varianten des Wohlstandsevangeliums in Afrika.' Theologische Zeitschrift 69 (1/2): 146-171.

Heuser, Andreas, ed. 2015. Pastures of Plenty: Tracing Religio-Scapes of Prosperity Gospel in Africa and Beyond. Frankfurt am Main: Peter Lang.

Heuser, Andreas. 2016. 'Die "verkannte Schwellenzeit" der Missionsgeschichte. Erkundungen zur postkolonialen Formierungsphase des Diskurses um Weltchristentum.' In Transformationen der Missionswissenschaft. Festschrift zum 100. Jahrgang der ZMR, edited by Mariano Delgado, Michael Sievernich, and Klaus Vellguth, 266-276. St. Ottilien: EOS.

Hollenweger, Walter J. 1998. 'Foreword.' In African Initiatives in Christianity: The Growth, Gifts and Diversities of Indigenous African Churches - a Challenge to the Ecumenical Movement, edited by John S. Pobee and Gabriel Ositelu, ix-xiii. Geneva: World Council of Churches.

Ilo, Stan Chu. 2014. The Church and Development in Africa: Aid and Development from the Perspective of Catholic Social Ethics. Eugene, Oregon: Pickwick Publications.

Jones, Ben, and Marie Juul Petersen. 2011. 'Instrumental, Narrow, Normative? Reviewing Recent Work on Religion and Development.' Third World Quarterly 32 (7): 1291-1306. https://doi.org/10.1080/01436597.2011.596747.

Kaag, Mayke, and Maud Saint-Lary. 2011. 'The New Visibility of Religion in the Development Arena.' Bulletin de l'APAD 33. 


\section{Philipp Öhlmann et al.}

Kgatle, Mookgo S. 2017. 'The Unusual Practices within Some Neo-Pentecostal Churches in South Africa: Reflections and Recommendations.' HTS Theological Studies 73 (3): 1. https://doi.org/10.4102/hts.v73i3.4656.

Lekganyane, Barnabas Edward. 2016. 'Easter Sermon 2016.' 27 March.

Marais, Nadia. 2015. 'Imagining Human Flourishing? A Systematic Theological Exploration of Contemporary Soteriological Discourses.' Doctoral Dissertation, Stellenbosch University.

Masondo, Sibusiso. 2013. 'The Crisis Model for Managing Change in African Christianity: The Story of St John's Apostolic Church.' Exchange 42 (2): 157-174. https://doi.org/10.1163/1572543X-12341262.

Masondo, Sibusiso. 2014. 'The African Indigenous Churches' Spiritual Resources for Democracy and Social Cohesion.' Verbum et Ecclesia 35 (3): 1-8. https://doi. org/10.4102/ve.v35i3.1341.

Mawere, Munyaradzi. 2014. Culture, Indigenous Knowledge and Development in Africa. Reviving Interconnections for Sustainable Development. Bamenda, Cameroon: Langaa Research \& Publishing CIG.

Maxwell, David. 2005. 'The Durawall of Faith: Pentecostal Spirituality in Neo-Liberal Zimbabwe.' Journal of Religion in Africa 35 (1): 4-32. https://doi.org/10.1163/15700660 52995825.

Mayer, Theresa. 2019. 'AICs in Ghana - Between Hotspot of the Holy Spirit and Postcolonialism.' Working Paper.

Meireis, Torsten, and Gabriele Rippl, eds. 2019. Cultural Sustainability. Perspectives from the Humanities and Social Sciences. London: Routledge.

Metz, Thaddeus. 2011. 'Ubuntu as a Moral Theory and Human Rights in South Africa.' African Human Rights Law Journal 11 (2): 532-559.

Meyer, Birgit. 2004. 'Christianity in Africa: From African Independent to PentecostalCharismatic Churches.' Annual Review of Anthropology 33: 447-474.

Mtata, Kenneth, ed. 2013. Religion: Help or Hindrance to Development? Leipzig: Evangelische Verlagsanstalt.

Myers, Bryant L. 2011. Walking with the Poor: Principles and Practices of Transformational Development. New York: Orbis Books.

Öhlmann, Philipp, Marie-Luise Frost, and Wilhelm Gräb. 2016. 'African Initiated Churches' Potential as Development Actors.' HTS Theological Studies 72 (4). https:// doi.org/10.4102/hts.v72i4.3825.

Öhlmann, Philipp, Marie-Luise Frost, and Wilhelm Gräb. forthcoming. 'You need to change the whole person - African Initiated Churches and sustainable development.' In Does Religion Make a Difference? edited by Andreas Heuser and Jens Köhrsen.

Öhlmann, Philipp, Stefan Hunglinger, Wilhelm Gräb, and Marie-Luise Frost. 2018. Religion and Sustainable Development: The 'Secular Distinction' in Development Policy and its Implication for Development Cooperation with Religious Communities: Religion and Development Discussion Paper 03/2018. Berlin: Humboldt-Universität zu Berlin. www. rcsd.hu-berlin.de/de/publikationen/pdf-dateien/discussion-paper-2018-03_religion_ sustainable_development.pdf/at_download/file.

Oosthuizen, Gerhardus C. 1987. 'The AIC and the Modernisation Process.' Africana Marburgensia 20 (1): 59-81.

Oosthuizen, Gerhardus C. 1988. 'Interpretation of Demonic Powers in Southern African Independent Churches.' Missiology 16 (1): 3-22.

Oosthuizen, Gerhardus C. 1997. African Independent Churches and Small Businesses: Spiritual Support for Secular Empowerment. Pretoria: Human Sciences Research Council. 
Oosthuizen, Gerhardus C. 2002. 'African Independent Churches (AICs): Spritual Support for Secular Empowerment.' Journal for Constructive Theology 8 (1): 3-11.

Ositelu, Rufus Okikiola Olubiyi. 2016. Christianity: Inside Story from an African Perspective. Shagamu: TCLAW Publications.

Padwick, John, and Nicta Lubaale. 2011. 'Harnessing Popular Visions for Social Transformation: The Experience of the OAIC in its Work with African Independent Churches.' In Ter Haar 2011, 315-330.

Pauw, Christoff M. 1995. 'African Independent Churches as a 'People's Response' to the Christian Message.' Journal for the Study of Religion 8 (1): 3-25.

Phiri, Isabel Apawo, Dietrich Werner, Kennedy Owino, and Chammah Kaunda, eds. 2016. Anthology of African Christianity. Oxford: Regnum Books International.

Pobee, John S., and Gabriel Ositelu. 1998. African Initiatives in Christianity: The Growth, Gifts and Diversities of Indigenous African Churches - a Challenge to the Ecumenical Movement. Geneva: World Council of Churches.

Ruele, Moji. 2016. 'The Prosperity Gospel and Economic Growth in African Christianity.' In Phiri, Werner, Owino, and Kaunda 2016.

Said, Edward Wadie. 1978. Orientalism. New York: Pantheon Books.

Schlemmer, Lawrence. 2008. Dormant Capital: The Pentecostal Movement in South Africa and its Potential Social and Economic Role. Johannesburg: Centre for Development and Enterprise.

Sundkler, Bengt G.M. 1961. Bantu Prophets in South Africa. London: Oxford University Press.

Swart, Ignatius, and Elsabé Nell. 2016. 'Religion and Development. The Rise of a Bibliography.' HTS Theological Studies 72 (4). https://doi.org/10.4102/hts.v72i4.3862.

Ter Haar, Gerrie, ed. 2011. Religion and Development: Ways of Transforming the World. New York: Oxford University Press.

Ter Haar, Gerrie. 2011. 'Religion and Development. Introducing a New Debate.' In Ter Haar 2011, 3-25.

Thiani, Evangelos. 2016. 'The Financial Stability and Self-Reliance of African Churches.' In Phiri, Werner, Owino, and Kaunda 2016.

Togarasei, Lovemore. 2016. 'The Prosperity Gospel in African Christianity.' In Phiri, Werner, Owino, and Kaunda 2016, 1006-10.

Tomalin, Emma. 2015. 'Introduction.' In The Routledge Handbook of Religions and Global Development, edited by Emma Tomalin, 1-14. Hoboken: Taylor and Francis.

Turner, Harold W. 1967. 'A Typology for African Religious Movements.' Journal of Religion in Africa 1 (1): 1-34. https://doi.org/10.1163/157006667X00011.

Turner, Harold W. 1979. Religious Innovation in Africa: Collected Essays on New Religious Movements. Boston: G.K. Hall.

Turner, Harold W. 1980. 'African Independent Churches and Economic Development.' World Development 8 (7-8): 523-533. https://doi.org/10.1016/0305-750X(80)90037-6.

United Nations. 2015. Transforming Our World: The 2030 Agenda for Sustainable Development. New York: United Nations.

van Wensveen, Louke M. 2011. 'Religion and Sustainable Development. A Typological Analysis.' In Ter Haar 2011, 81-108.

Varela, María do Mar Castro Varela, and Nikita Dhawan. 2015. Postkoloniale Theorie. Eine kritische Einführung. Bielefeld: Transcript.

Venter, Dawid. 2004a. 'Concepts and Theories in the Study of African Independent Churches.' In Venter 2004b, 13-43.

Venter, Dawid, ed. 2004b. Engaging Modernity: Methods and Cases for Studying African Independent Churches in South Africa. Westport: Praeger. 


\section{Philipp Öhlmann et al.}

World Commission on Environment and Development. 1987. Our Common Future: Report of the World Commission on Environment and Development 41.

Ziai, Aram. 2017. 'Willkommen in Zhengistan, ÄthiopierInnen!' Postkoloniale Perspektiven auf Entwicklungspolitik. Inaugural Lecture for the Heisenberg Professorship for Development Policy and Postcolonial Studies at University of Kassel. Kassel: Universität Kassel. www.unikassel.de/fb05/fileadmin/datas/fb05/FG_Politikwissenschaften/Entwicklungspolitik/ Antrittsvorlesung.pdf 


\section{Part I}

\section{Overarching perspectives}


$\Longrightarrow$ Taylor \& Francis Taylor \& Francis Group http://taylorandfrancis.com 


\title{
2 Spirit and empowerment The African Initiated Church movement and development
}

\author{
J. Kwabena Asamoah-Gyadu
}

\section{Introduction}

This chapter explores the relationship between the African Independent/ Instituted/Initiated Churches (AICs) and development. The Christian religious sphere labeled 'African initiated' has widened considerably since these movements came to attention in the early twentieth century. Christian independency of the pneumatic kind started in Africa with the Spiritual (Ghana), Aladura (Nigeria) or Zionist Churches (South Africa), but today they include various contemporary urban-centred independent Pentecostal and neoprophetic movements that came into being at the end of the twentieth century. The new urban-centred and prosperity-preaching Pentecostals receive a disproportionately higher attention in this study because, although some of their activities have been inspired by North American televangelism and in spite of their transnational networks, they are also 'African' and 'independent' of the historic mission denominations. In order to bridge the historical and doctrinal divides among the various independent Christian movements, we will use the umbrella expression African Initiated Churches when referring to them as a collective entity with shared characteristics and call each of them by name when we need to highlight their distinct historical and religious identities.

I refer to 'Spirit' in the title because the movements we deal with here whether they belong to the older Independent Church tradition or the more contemporary Pentecostal and neo-prophetic categories - all privilege the experiences of the Spirit in their activities (Asamoah-Gyadu 2005). It is as a result of the experience of the Holy Spirit as the defining factor in their theological self-definition that in referring to them, I sometimes use the expression 'pneumatic movements' in order to accommodate the different versions available. Indeed, in African countries like Ghana, the older Independent Churches would normally be called 'Spiritual Churches' as the experiences, power, and expressions of the Holy Spirit loomed very large in their worship, prayer, and activities (Baëta 1962,1). The expression 'empowerment' is chosen as a category of development because ultimately, development has to do with the power to forge ahead in the desire for a better life. And, indeed, the older Spiritual Churches in Ghana have often advertised their services in terms of places where 
people could go for mpontu, literally, development in all areas of their lives. This theology of mpontu, development, is what has been reinvented in contemporary Pentecostal prosperity discourses as 'dominion' and both expressions relate to the idea of human flourishing.

\section{Religion and development}

The original African Independent Churches developed rapidly from the early decades of the twentieth century, becoming the representative face of Christianity on the continent. This only changed from the 1970s with the rise of the contemporary urban-based prosperity-preaching Pentecostals or Charismatics. This chapter deals with the interface between religion and development generally but examines in particular the relevance of Africa's independent Christian pneumatic movements to development on the continent. Development has to do with visible, enduring, and measurable qualitative upward mobility in human life and society. Its associated terms and expressions include expansion, growth, progress, success, and prosperity. Religion, on the other hand, is about the relationship between two realms of existence - the divine and the human - and all that goes into making life empowering, better, and worth living. When people and societies develop, the desire to live increases because life becomes meaningful. Religion and development is now an important area of academic study, especially within the social sciences (Haar, 2006, 351-367). In both the Old and New Testaments, human development seemed to be at the centre of religious life as it relates to God. Thus, following creation, God details Adam and Eve to take care of it and therefore make a living out of creation:

And God blessed them. And God said to them, 'Be fruitful and multiply and fill the earth and subdue it and have dominion over the fish of the sea and over the birds of the heavens and over every living thing that moves on the earth.' And God said, 'Behold, I have given you every plant yielding seed that is on the face of the earth, and every tree with seed in its fruit. You shall have them for food.'

(Genesis 1:28-9)

The very survival of the human species, according to this text, was going to depend on the extent of creation care. The continuous existence of creation including human flourishing was therefore going to depend on proper care of the resources made available through divine initiative. Thus, to exercise 'dominion' here meant to take responsibility so that humanity could work on creation for sustenance, survival, preservation, and well-being. In the New Testament, too, we find that several of the interventions that Jesus made in the lives of people was to ensure that they would be able to eke out a living without having to depend on others because of various disabilities. If we consider the woman with the 12-year-old haemorrhage, for example, we are told that she had spent 
all her money on healthcare without results (Luke 8:43-8). This meant that her condition had affected her severely in economic terms, and, presumably, also her personal well-being. The fact that she suffered ritual marginalisation was dehumanising but Jesus worked towards the restoration of such persons to proper functioning order. The words of Jesus are that, as the Good Shepherd, he came, so that people 'might have life and have it in its fullness'. In contrast, the devil comes to 'steal, kill and destroy' (John 10:10).

In the theological discourses of the African Initiated Churches we discuss here, the statement of Jesus could never have simply meant that believing in him had only eschatological implications to the exclusion of existential ones. In other words, the fullness of life that Jesus talks about is understood in the African Initiated Church movement to have existential relevance. Our faith, it is thought, must always have a developmental agenda at its core because God delights in human flourishing. How this developmental agenda is expressed in the lives and ministries of Africa's Independent Indigenous and Pentecostal/ Charismatic movements is what this chapter is about. Thus, whether we are talking about the prayer gardens and mountains of the older Independent Churches or the summits and conventions of the more contemporary ones, the fact that the forces of delay, oppression, stagnation, and negativity - in both their physical and spiritual manifestations - ought to be exterminated in the power of the Spirit features very strongly in the religious practices of the African Initiated Churches we discuss in this chapter.

\section{The African Independent Church movement}

We need to place the movements I have mentioned above in their proper historical context before we proceed. The African Initiated Church movement, we have noted, was from its beginnings in the early twentieth century associated with the work and experiences of the Holy Spirit. They were called 'African' because they were indigenous and the expression 'independent' referred basically to their relationship with western mission bodies and agencies. The emergence of the African Independent Churches was the result of disenchantment with what was considered the staid and cerebral forms of Christianity associated with the historic mission denominations with their weak sense of supernatural power, especially the interventionist nature of the ministry of the Holy Spirit. They were followed from the 1930s onwards by the classical Pentecostal denominations. A number of these like the Assemblies of God and various Apostolic denominations came from Europe and North America. However, several of them, such as Ghana's Church of Pentecost, have also become very indigenous with time. Except for South Africa, because of its peculiar political heritage, the early-twentieth-century African Independent Churches are not doing too well in terms of survival and growth and the factors accounting for this trend are many. They include the incapacitation of the original founders due to ill health, old age, or both. Some of the original leaders have passed on and for movements built on the personal charisma and psychology of its leadership, the decline is 
understandable as many did not train successors to take over from them. The propensity towards secession was also very high and this coupled with their failure to develop intergenerational ministries, lack of accountability, and the routinisation of charisma have all contributed to the decline of the African Independent Churches (Asamoah-Gyadu 2005).

In spite of their decline, to concentrate on that development would be deceptive because even if they perish, their contribution as trailblazers of pneumatic Christianity in Africa would continue to stand as testimony to their historical impact. In my book African Charismatics, I have discussed the contribution of the Independent Churches to Christianity in Africa under six main themes. These are: the integration of charismatic renewal into expressions of Christianity; a practical orientation towards salvation that created the theological space for rituals that accommodated real needs such as health, unemployment, marriage, and successes in business; a dynamic pneumatology in which the empowering presence of God was coveted not just for the manifestations of the gifts of the Spirit but also for various practical life concerns; the use of oral theology in liturgical expressions such as the use of locally composed choruses and the narrations of personal testimonies of salvation; and an innovative gender ideology in which space was created for women to exercise leadership based on their charismatic experiences rather than the stereotypes that excluded them from Christian leadership. We will not concern ourselves much with the classical Pentecostal traditions, as the interest of this chapter lies more with African Initiated Christianity, both the classical Independent Churches and the new prosperity-preaching Charismatic ministries, as they are popularly called in Ghana.

The study of Christian religious innovation in Africa must consider the fact that there is some measure of continuity between the early-twentieth-century African Independent Churches and the late-twentieth-century contemporary Pentecostal movement. For example, the early Independent Churches were associated with prophetic and healing ministries, but those phenomena have been reinvented within contemporary Pentecostal religious practices as well. On the matter of continuity, my favourite quote on it comes from the doyen of the academic study of Christianity in Africa, Andrew F. Walls:

Until recently these prophet-healing churches could be held the most significant and the fastest-growing sector of the indigenous churches. This is no longer so certain. Nigeria and Ghana, to name but two countries, are witnessing the rise of another type of independent church.... Like the prophethealing churches, they proclaim the divine power of deliverance from disease and demonic affliction, but the style of proclamation is more like that of American Adventist and Pentecostal preaching.... Yet these radical charismatic movements are African in origin, in leadership, and in finance. They are highly entrepreneurial and are active in radio and television and cassette ministries as well as campaigns and conventions.... All these new movements share with the prophet-healing churches a quest for the 
demonstrable presence of the Holy Spirit and a direct address to the problems and frustrations of modern urban life.

(Walls 1996, 92-93)

In West Africa the growing unpopularity of African Independent Churches led to a number of them shedding their traditional outlook and taking on some of the phenomenological characteristics of the contemporary Pentecostals. The characteristic features of the contemporary Pentecostals are fairly well known: they are led by very gifted and better-educated (as compared to prophets of the Independent Churches) charismatic leaders; they hold a great attraction for Africa's upwardly mobile youth and young professionals.

Contemporary Pentecostal and neo-prophetic movements boast of urbanbased mega size congregations, a very international outlook and they belong to important transnational networks. They make extensive use of modern media technologies and foster in their members an entrepreneurial spirit through motivational messages of success, prosperity, positives, and possibilities. As Andrew Walls alludes to in the quotation above, they also seem to pursue an ardent quest for the demonstrable presence of the Holy Spirit to address the problems and frustrations of modern urban life in Africa. This is what prosperity preaching is about. Spiritual and physical empowerment for upward mobility lies at the heart of the discourses on prosperity. The contemporary Pentecostals, as independent churches, have shed some of the Old Testament and traditional religious features of the African Independents such as wearing white and red garments and worshipping bare-footed in imitation of the experience of Moses on Mount Sinai. They also do not subscribe to those Levitical codes that became an albatross around the necks of women in spite of what we have referred to as their innovative gender ideology.

\section{History of religious innovation and development in Africa}

Christianity has now developed as a non-western enterprise with Africa as one of its major heartlands. This is surely one perspective in which to appreciate the need to examine the relationship between faith and development from the perspectives of the movements that we are referring to collectively as African Initiated Churches. Besides the biblical mandate, this topic of the relationship between Christianity and development is also important for several other reasons. We examine this connection from the perspective of the African Initiated Church movement in Africa. Ultimately, religion, including those with strong eschatological orientations is generally expected to lead to some measure of development in human life and society. Religion that is socially retrogressive must be considered inimical to human progress and development. Considered from the viewpoint of the historic mission denominations, in particular, they have always maintained a strong relationship between Christianity and development in Africa. In an edited volume by Paul Gifford on Christianity and democratic governance in late-twentieth-century Africa, contributors lauded 
the efforts of the historic mission denominations for their interventions in saving various countries from descending into sociopolitical anarchy at the hands of Africa's military dictators and civilian autocratic leaders (Gifford 1995). These traditional historic western mission denominations, for example, have always also been appreciated for their interest in the promotion of formal education, literacy work, and medical care. In the last couple of years some of these historic mission denominations in Africa have moved into higher education. There are now Methodist, Catholic, Presbyterian, Anglican, and Baptist Universities spread across various African countries including Ghana, Nigeria, and Zimbabwe.

During the second half of the twentieth century, this attention to socioeconomic and human development by the historic mission denominations led to popular accusations that the African Independents, and later the Pentecostals, had become too 'heavenly minded' to be of any 'earthly good'. And indeed, for most Pentecostals, there was much emphasis on the Second Coming of Christ leading to cautionary sermons on the pursuit of wealth and the acquisition of material things in this world. There are testimonies in Africa of people abandoning their university education to preach the gospel, because, for them, the Second Coming of Christ was imminent. Until the emergence of the prosperity gospel within contemporary Pentecostalism in Africa, for example, wealth had been generally demonised as constituting the greatest obstacle to spending eternity with God. The early African Independent Churches and the classical Pentecostal Churches that came after them stressed the eschatological importance of Christianity to the neglect of its existential relevance for the lives of people in this present existence.

The questions that were raised in relation to the earthly relevance of African religious movements were legitimate for two simple reasons: first, the African continent has for the longest time been associated with all that was wrong with human society - hunger, poverty, economic deprivation, and squalor - and it was to be expected that Christian movements would be at the forefront of the developmental agenda of the continent. Second, and related to the first reason, was that the African Independent Churches had attracted masses of people, and it was expected that since development was about human life and well-being, they were going to take advantage of their leverage in numbers to pursue a developmental agenda. In many cases, unfortunately, this did not happen, at least not to the extent to which society expected it to. The early Independent Church movement paid considerable attention to the personal development of their patrons, especially when it came to issues relating to marriage, employment, and ill health. Their relevance for the African context lay in the fact that these Independent Churches took African worldviews of spiritual causality seriously, and, as we argue here, sought the intervention of the Holy Spirit in dealing with those forces of retrogression in human life.

In 1979, one of the pioneering scholars in the study of new religious movements in Africa, Harold W. Turner, issued in one volume a number of his previously published essays under the title Religious Innovation in Africa. He is the one 
who first used the expression 'prophet-healing churches' to describe the classical African Independent Churches (Turner 1979). The chapters were placed under such headings as 'methodological and bibliographical', 'historical', 'religious case studies', 'theological and liturgical', 'missiological', and, very instructively, 'sociopolitical', That the first of three essays in the sociopolitical section was titled 'The Place of Independent Religious Movements in the Modernization of Africa', was itself very instructive. It brought to the fore the tensions that had emerged in popular discourses on the relevance of the churches initiated in Africa to the development of the nations in which they seemed to be thriving. In many countries, they had been castigated by officialdom and berated as a 'nuisance' because they 'polluted' the atmosphere with excessive noise, exploited vulnerable Africans, especially women, ran down the public-school classrooms in which a lot of them were meeting, and took people away from productive activities through endless prayer meetings and prolonged church services. Nevertheless, they had their admirers among the populace. There were many political and public office holders who patronised the prophetic and healing activities of the African Independent Churches for whatever spiritual benefits that inured to them from the charismatic figures who led these African religious movements.

At the overthrow of Ghana's Kwame Nkrumah in February 1966, for example, the Christian Council of Ghana, which is constituted by the historic mission denominations, felt scandalised by the fact that it was Apostle C. K. Wovenu of the Apostles Revelation Society who was invited to 'cleanse' the seat of government before the new military junta moved in. The historic mission denominations had from the beginning considered the African Independent Churches as constituting aberrations of Christianity. The therapeutic methods of the new movements were considered to be too close to traditional religious practices for comfort and the lack of theological education in their leaders served to cast doubt on the ability of these self-proclaimed prophets in providing quality and balanced pastoral care for the teeming following. The fact that most of the members of the Independent Churches came from the older denominations did not help matters and Apostle Wovenu himself was a former lay leader of the Evangelical Presbyterian Church, a leading member of the Christian Council of Ghana. The worldview behind this invitation to cleanse the castle of evil influences was simple: whereas the average historic mission minister was considered theologically educated, the prophets of the African Independent Churches were considered the custodians of real charismatic power. What was needed at the time were not services of a pastor with the ability to read ceremonial prayers or collects, but one with the requisite anointing of God to deal with what vestiges of evil influence presumably lingered at the seat of government as left by President Nkrumah. The general belief was that behind the facade of his Catholic faith and political charisma, President Nkrumah also patronised the activities of various occult groups and traditional shrines for power to govern (Fernandez 1970).

The general impression at the time then was that the African Independents, led by their prophets, concentrated on dealing with the spiritual problems of 
their clientele. People came looking for love potions, healing for chronic ailments, employment, good fortune, and other such needs that lay within the realms of the worldviews of mystical causality that still drives people to look for help from various religious functionaries. This is a matter that has been held against the independent church movement since their inception and it is a reservation that has followed the operations of certain contemporary Pentecostal prophets too. It is considered developmentally retrogressive for seemingly mundane problems in life to be so spiritualised that people refuse to take responsibility for their actions and inactions and rather explain their problems in terms of supernatural causes. This worldview of mystical causality extends into national life in many African countries. Corrupt governments have fallen on it to explain the hardships of their people and called for periods of national fasting and prayer for God to intervene when in fact the problems have been caused by the misappropriation of state resources and the abuse of political power. The political alienation and social anomie experienced by many ordinary Africans meant that the spiritualisation of national problems was perhaps the only way in which people could come to terms with the socioeconomic challenges.

I have already stated that the early African Independent Churches have made some positive contribution to the history and growth of Christianity in Africa. It has not all been doom and gloom for within the many African Independent Churches that have existed in Africa, there are a good number that have been led by credible prophetic figures whose contribution to Christianity and political life has not been in doubt. The point is that given this backdrop of the obsession with the so-called spiritual matters by the African Independent Churches in the minds of the general public, especially their critics, it was groundbreaking for Turner to have given some attention to 'the place of independent religious movements in the modernization of Africa'. The abstract to the essay which I reproduce below makes clear that Turner was in fact responding to the general opprobrium against the African Independent Churches for being developmentally retrogressive as compared to the more established historic Mission Churches:

This essay seeks to counter the image of these movements as ignorant and reactionary, compensating people for their miserable lot in life in a turbulent Africa, but diverting energies from national development and modernization. The deeper dimensions of the cultural changes necessary for such development are explored in relation to the new forms of life and the new world views offered by the new religious movements.

(Turner 1979, 297)

At the beginning of the essay, Turner alludes to the contribution of Christian missions and churches to the development of the new independent states of Africa through formal education and 'their association with Western culture and its political forms and ideas' that had been a major factor 'in the growth of 
nationalist sentiment and the achievement of political independence' (Turner 1979, 298). Given that these earlier contributions were fairly well known, Turner turns his attention to 'an examination of the relation between the modern secular nation-states and other less-known religious groups' (Turner 1979, 298). These, as he notes, claimed a Christian orientation and had emerged from the older missions and churches in increasing numbers since the end of the nineteenth century (Turner 1979, 298). In this essay Turner refers to the contributions of various religious movements to the revolt against European political oppression from the nineteenth century and how in the early-twentieth century, independent Christian prophets like Simon Kimbangu of the Belgian Congo had led protests against these colonial hegemonic tendencies in governance. In other words, Turner was arguing that the emergence of nationalism in the immediate pre-independence period was not to be restricted to the more elite leadership of the historic Mission Churches. He goes on to make this telling observation based on the work of Prophet Simon Kimbangu:

The relation between the religious and political components in these independent movements varies from one to another and at different periods in the history of any one group, so that generalizations must be treated with the greatest care. Some movements have been primarily religious in their original concerns and activities but been forced into political action or revolt when colonial authorities have misinterpreted them as centers of subversion, insofar as any new independent African activity and organization was regarded as politically dangerous. This seems to have been the fate of the genuinely religious healing movement of Kimbangu, although no one can say that it would never have developed political concern if the Belgians had not greeted it with severe repression.

(Turner 1979, 299)

Based on the experiences of Simon Kimbangu and others including the work of the Liberian Prophet William Wadé Harries of West Africa, Turner concludes that 'a considerable number of independent religious movements in Africa [had] actively contributed to the development of political nationalism at some stage in their history' (Turner 1979, 299).

In relation to their contribution to the emergence of pro-political independence in Africa, Turner also cites the ability of many African Independent Churches to transcend 'the limitations of language, tribe, and region' to create a wider community of people. There were a number of Independent Churches, such as the Aladura movement of Nigeria that were very ethnically biased in terms of composition, nevertheless it could be said that especially in urban Africa these movements were able to establish communities of faith that dissolved tribal considerations and more importantly created space for the socially marginalised in their religious communities. The African Independent Churches also spread beyond national boundaries with churches from Ghana, Nigeria, and South Africa spreading into other countries and bringing together people who 


\section{J. Kwabena Asamoah-Gyadu}

were otherwise separated by socio-ethnic backgrounds. On the importance of this to the modernisation of Africa, Turner concludes:

Here we have the beginnings of a new sense of identity over against other races and their churches, often coupled with the vision of great African church that will command the respect of the whole world and make its own special contribution to the religions of [hu]mankind.... In spite of the fissiparous nature of these religious movements this sense of belonging to a great African spiritual and Christian community seems to be more conspicuous than notions of a single church for the nation.

$(1979,301)$

There are other areas in which the African Independent Churches could be said to have contributed to the development of modern Africa. The historic mission denominations were elitist in many senses on account of the close relationship that they had created between Christianity and education on the one hand and public service on the other. A majority of African public servants were trained in mission schools and in urban Africa, many of the historic Mission Churches preferred to worship in foreign tongues through the use of western hymnody, homiletical exercises, and even church wear. In contrast, the classical African Independent Churches did well in forming churches that helped those down the social ladder to feel at home. Their modes of worship, liturgical practices, and physical structures were less sophisticated and so they helped to create space for those feeling the heat of the religious anomie in the older denominations. Beyond that the use of the vernacular in Christian worship helped to make practical the translations of the Bible in various vernaculars by the agents of Christian mission and give indigenous languages life beyond the classroom. Harold Turner is not the only scholar to pay attention to the relationship between the African Independent Churches and development. An edited collection, Engaging Modernity: Methods and Cases for Studying Independent Churches in South Africa, also gives considerable attention to this matter (Venter 2004). One of the essays here by Robert Garner studies the 'African Independent Churches and Economic Development' in a South African township, Edendale. In Zimbabwe, creation care, in terms of environmental preservation through best practices in reforestation, has been the primary preoccupation of the Independent Church movement for many years. Thus, as Harvey Cox notes in reference to the writings of Inus Daneel, the African Independent Churches in Zimbabwe were not only healers but also ecological preservationists. Any activities that lead to soil erosion, fouling the water supply, or chopping down trees without replacing them constitute ecological offences against the Earthkeeping Spirit (Cox 1995, 245).

There are a number of important conclusions that the essay arrives at, but perhaps the most important is the stress on personal transformation in these churches and its implications for ethics and morality on societal development. The legacy of the African Independent Churches includes the affirmation of 
African identities and cultures through indigenous expressions of the faith evident in their therapeutic methods and the preaching of the gospel in familiar idioms. A few of them went on to invest in physical development such as schools and hospitals although on the whole this was not a major strength. Their fissiparous nature affected their economic muscle, and, so, in the end, many remained very small and virtually fizzled out when their founders either became invalid, lost their charisma, or passed on. On the whole it would be difficult to talk about Christianity as a non-western religion without reference to the theological innovation of the Independent Church movement that burgeoned across Africa from the last decade of the nineteenth century, becoming the representative face of the faith until the rise of modern Pentecostal movements from the middle of the twentieth century.

\section{Paradigms of prosperity}

Donald E. Miller and Tetsunao Yamamori have referred to sections of the contemporary Pentecostal movements as Progressive Pentecostals (Miller and Yamamori 2007). The authors define Progressive Pentecostalism as '[Pentecostal] Christians who claim to be inspired by the Holy Spirit and the life of Jesus and seek holistically to address the spiritual, physical, and social needs of people in their community' (Miller and Yamamori 2007, 2). Progressive Pentecostalism thus stems from the clear attention that a number of them are now giving to social developmental issues. This places on the back burner the eschatological message relating to the Second Coming of Christ and the coming judgement that will result in some spending eternity in hellfire and others enjoying with God in heaven. These eschatological discourses do not feature much in contemporary Pentecostal sermons. This orientation towards social and human development is seen in the massive support that Ghanaian Charismatic Churches now give to charitable courses. Mensa Otabil's International Central Gospel Church (ICGC) has built a new information technology centre for Ghana's biggest orphanage, the Osu Children's home. ICGC is also the single highest donor to the cardiothoracic centre at Ghana's main teaching hospital. It has established a private university - the first Pentecostal university to be chartered by government - and its focus is to develop capacity in the areas of business management, entrepreneurial studies, and medical professions such as nursing. This story of ICGC is equally true of David Oyedepo's Living Faith Church Worldwide, also known as Winners' Chapel, and Enoch Adeboye's Redeemed Christian Church of God both based in Nigeria. What this means is that contemporary Pentecostals, which in the past propounded a simplistic gospel of prosperity now combine that with significant emphasis on social and economic development.

The emphasis now remains on prosperity as the divine right of every believer, but, as we shall note below, the message is now a bit more nuanced than when these churches started preaching in the late 1970s. When prosperity preaching which has its source in North American televangelism started, there was much 
emphasis on the name-it-and-claim-it approach. In what Nimi Wariboko refers to as the 'covenant paradigm' in prosperity thinking, the metaphor used is the agricultural one of sowing and reaping:

[Sow] tithes and offerings, among other elements of a self-sacrificial way of life, into the church and reap bumper harvests of wealth. Lives flourish when these gifts are blessed by or joined with quasi-magical gifts of certain pastors (the fertile soil). The covenant paradigm emphasizes the status quo or ignores it; it is not oriented social change.

$(2014,234)$

In this sowing-and-reaping approach to prosperity, as Wariboko has articulated here, Christians are encouraged to be positive in their verbal declarations, fulfil their tithing obligations and sow seeds of money and other gifts in the life and ministry of their anointed charismatic leaders, and simply reap the results in material blessings.

To a large extent, this approach continues unabated, especially among a new crop of prophetic figures who through increased sophistication in terms of how they operate have followed the same approach as was found in the modus operandi of the old prophets of the African Independents. Andrew Walls gives us a clue why this is so:

Christianity has thus necessarily inherited all the old goals of religion; in particular, the association with protection and with power is undiminished.... The effectiveness of the Christian faith, or any particular manifestation of it, is accordingly open to the test of whether it gives access to power and prosperity to protection against natural or spiritual enemies (purposes to which much traditional practice was directed) and satisfactorily enforces familial and social duty.

$(2002,122)$

The new prophets operate through Independent Churches either as founders and pastors or simply as itinerant guest functionaries at revival meetings; they are present on television, radio, and even internet websites. These prophetic figures have many followers. Given the added fact that the worldview of mystical causality is still very much present in African ways of interpreting the world, the prophets rely on that and in some ways this leads to the exploitation of the fears and insecurities of their patrons to accumulate personal wealth. In this vein Paul Gifford who has explored the relationship between Christianity and development in Africa against the backdrop of the strong belief in mystical causality has noted that the enchanted religious imagination, as he calls it, has not died out on the continent $(2015,14)$. The prosperity preachers in this covenant paradigm, Wariboko notes, do not merely address poverty and fuel greed. They produce desires and dreams and connect them to the transcendental God. There is some positive element here in that the preachers 'motivate believers to become 
agents of their own personal economic improvement' but the downside of it is that it takes a simplistic approach to development and leaves those who fulfil their covenant obligations and yet continue in poverty and suffering without adequate answers to the quagmires of life (Wariboko 2014, 236).

\section{Hermeneutics of black empowerment and development}

There is a second model of prosperity that Wariboko terms the 'excellence model'. This model, according to Wariboko, dwells on human capability development and Afrocentric sentiments. He explains how this model works in prosperity gospel hermeneutics within the context of contemporary Pentecostalism or Charismatic Christianity in Nigeria:

If Nigerians are sowing and reaping material blessings, they must do so, according to the proponents of this model, with the best machinery and organization. The operation of these technologies must be sustained and advanced by the ethos of professional excellence. This model says that Nigeria has failed in economic development because there are too few sane, resourceful, and patriotic managers who can bring together and develop the right talents to orchestrate development in the various spheres of the economy. The excellence model is a triangle of nationalism (Afrocentric view), professionalism (human capacity building), and the prosperity gospel orientation to development.

(Wariboko 2014, 238)

What this means however is that in recent decades, the simplistic positive confession and sowing-and-reaping forms of prosperity, have been balanced by other charismatic pastors with a more pragmatic approach in which the stress is on hard work, the constructive and wise use of gifts and talents, and the pursuit of relevant educational programmes. One of these new motivational speakers is Mensa Otabil of Ghana and his approach to prosperity has been very well analysed by Paul Gifford (2004) in his book Ghana's New Christianity. This chapter is written under the broad title of spirit and empowerment for the reason that spiritual and human development lies at the heart of the new hermeneutics we come across in contemporary Pentecostalism in particular. A representative list of the preachers of this new hermeneutic of black empowerment would include Bishop T. D. Jakes of the Potter's House Church in Texas, USA, Matthew Ashimolowo of the Kingsway International Christian Center in London, and Mensa Otabil of Ghana. In Nigerian Pentecostalism Nimi Wariboko gives the following succinct summary of the sort of hermeneutics of development or empowerment that I speak of here:

It is the belief in the power of Pentecostalism - the movement of the Holy Spirit and the power to initiate something new - to transform and elevate African society and the dignity of the black race. Within a certain segment 
of Nigerian Pentecostalism the only way of living acceptably to God was life not merely of holiness and personal salvation and wealth but by the fulfilment of an obligation to be God's battle-ax to uproot and destroy economic backwardness and the black race's indignity. This was their calling. They saw themselves as an instrument of the divine in the history of Africa.

$(2014,230)$

Wariboko then discusses how Pentecostals are 'bearing the weight of blackness' by articulating ideas of Christian citizenship and the desire for the 'greatness of the black race' $(2014,232)$. One of the books written by Mensa Otabil (1992), Beyond the Rivers of Ethiopia deals precisely with this sort of hermeneutics of empowerment. In this book Otabil writes that the average black person had to contend with western values and would be shaped by them. The end of our society having been suffused with western things is that blacks end up feeling inferior to the white race. Even Christian missionaries, he writes, assumed that everything African was evil and our indigenous names were demonised as satanic (Otabil 1992, 15). He then gives Africans the following charge in relation to our Christianity:

I do not believe the church in Africa should be ruled from anywhere but Africa! Our leaders must be home brewed. Our finances must be generated from the productive work of our own resources. Our headquarters must be in Africa! When it becomes necessary to co-operate with other churches and ministries beyond our continent, it must be based on mutual respect and love. We were not made in God's image to receive mercy drops! The times have changed, and God is calling on us to change our attitudes and expectations.

(Otabil 1992, 68)

The reference to Ethiopia in the narrative is very instructive. The country became the symbol of black emancipation as it was the only African country that resisted colonial rule and domination. Besides Ethiopia appears in the biblical narrative as quickly stretching out her hands to God (Psalm 68:31) and bringing God an offering (Zephaniah 3:10). These texts including the baptism of the Ethiopian eunuch by Philip in the Acts of the Apostles have inspired the thinking that Africa looms large in God's imagination and westerners must not be allowed to hold him in their custody. These thoughts are also present in the writings of Matthew Ashimolowo of the Kingsway International Christian Centre. In his book What Is Wrong with Being Black? he writes as follows:

It is my opinion that there is no culture that transcends any other culture, or stands superior to other cultures. The Bible is raised as the standard here because it is in it that we find what I consider the key root to Black 
pathologies and the final solution that will cause Blacks to come into the fullness of who they will be. It is the Bible that will cause them to come to a place of the true identification of their gift in God, transformation and a manifestation of the gifts and abilities that have been deposited in them from time immemorial.

The subtitle of Ashimolowo's book - Celebrating our Heritage [and] Confronting our Challenges - is very instructive regarding the sort of black empowerment hermeneutics that the new crop of motivational speakers are developing in Africa within the context of independent Pentecostalism.

\section{Pentecostal citizenship and social engagement}

The sort of contemporary Pentecostal social engagement that motivational pastors like Mensa Otabil and Matthew Ashimolowo represent begins with responsible citizenship. Miller and Yamamori summarise this orientation to civic responsibility as follows:

Progressive Pentecostals in most cases actually embrace capitalism and attempt to work within the system. In our opinion, however, Pentecostals are actually doing something fairly subversive. They are teaching their members that they are made in the image of God; that all people have dignity and are equal in God's sight; and that therefore they have rights whether they are poor, women, or children. These values are fundamental to the creation of a democratic government, and therefore, at the very least Pentecostalism is preparing good citizens who may exercise their vote in ways that affect egalitarian values.

$(2007,4-5)$

The reference to 'preparing good citizens who may exercise their vote' brings to mind a sermon that Pastor Mensa Otabil preached in his church titled 'Your Vote'. The message was first preached in the run-up to Ghana's presidential and parliamentary elections in 2012 and rebroadcast on various networks through his Living Word television, radio, internet stations, and websites prior to the 2016 elections. 'A vote is like an offering', Pastor Otabil continued and 'when we give to God, he gives it back to us in blessings'. In the same way, when we give politicians our vote, we must expect them to deliver on their promises. 'A vote is sacred', he explained, and therefore it is a way of entering into a covenant with the one for whom one votes. In a modern democracy, Pastor Otabil preached, citizens possess the right to vote and voting connotes endorsing an idea or system of governance. This was done in expectation that those we vote for would serve our interests: 'voting means giving support to an idea in expectation that the idea will benefit you; something beneficial must come out of one's vote' he explained. 
Pastor Mensa Otabil gave three main reasons for voting. First, 'your vote' is your sovereign will and when one votes he or she cedes that sovereignty to those in government. 'Your vote is about surrendering your sovereignty to the President and it is a very serious action because no citizen can govern legitimately without the collective votes of those who go to the polls' he noted. In voting, therefore 'each citizen must ask himself or herself: "does the person I am voting for deserve my sovereignty?"' Second, according to Pastor Otabil, we vote as a 'sacred responsibility of citizenship'. He explained how we must go beyond advertisements to scrutinise political party proposals to ensure that they serve the best interest of the nation. He cautioned that it was irresponsible to put one's vote on 'autopilot', meaning, citizens must never vote simply because they were affiliates of a particular political party or are related to someone seeking election into parliament: 'Be free to change your mind if those you have voted for in the past have not delivered on their proposals' he advised. Third, Pastor Otabil noted that 'our quality of life is determined by the results of our votes and therefore we should never allow any politician to take our votes for granted'. 'Vote for your beliefs and values', he advised and as a Christian your values must consist of truth, honesty, and integrity. 'Do not vote with selfish interests in mind', rather, he noted, 'vote for the best interest of the country'.

Pastor Otabil's sermon was relevant for citizenship and social engagement, because, in many African countries the loss of elections had not been taken lightly. Incumbent governments have sought to manipulate the systems of governance in order to perpetuate their regime leading to some of the bitterest conflicts that have occurred in countries like Ivory Coast, Liberia, and more recently the Gambia, all in West Africa (Gifford 1979). The connection Pastor Otabil makes between voting and a person's quality of life is also instructive. In African politics it is common practice for politicians to dole out little monies and gifts to especially poverty-stricken communities in subtle and blatant attempts to 'buy' their votes. Such people and communities are then neglected once the political office has been secured (Ranger 2008). What this sermon 'Your Vote' tells us is that certain categories of Pentecostals are taking public life and social engagement very seriously indeed. It further demonstrates that given their endurance and increasing influence, religious institutions like the Pentecostal/Charismatic Churches that are now dominating African religious life represent an important source of hope in times of social and political uncertainties. Certainly, the new charismatic motivational speakers fulfil such a role. Pastor Otabil cautions here about citizens not falling for vote-buying deceptions in Africa because, as he notes, those temporal gifts do not determine what quality of life one would have in future. 'It is your vote that counts!' He concluded.

\section{Conclusion}

The history of Christianity in Africa cannot be told without the influence and impact of the Independent Church movement. Although originally the 
expression African Independent Churches was used to describe the older forms of Christian religious innovation, it is becoming redundant for two reasons: first, although the classical African Independent Churches did not specifically refer to their movement as 'Pentecostal', phenomenologically, they were the first to exhibit a strong pneumatological religious culture in African Christianity. Second, although the contemporary Pentecostals may appear like North American versions of the same phenomenon, they are indigenous both in leadership and resource mobilisation. In both movements, the belief in mystical causality has been sustained. It is part of what makes the African. However, the initial concern with eschatological matters, especially in the contemporary Pentecostal movement, seems to have given way to more pragmatic matters as attention is now paid to social developmental issues. In that sense, in spite of whatever reservations one may have concerning the obsession with evil and rituals of exorcising it, African Initiated Christianity in both its classical and contemporary forms can to some reasonable extent be considered as constituting vehicles of modernity and development. What the examples in this chapter tell us is that the other-worldly characteristic initially associated with Pentecostalism is changing. An emergent group of Pentecostals, Miller and Yamamori observe, 'is pursuing the integral, or holistic, gospel in response to what it sees as the example of Jesus, who both ministered to people's physical needs and preached about the coming kingdom of God' (2007, 21-22).

\section{References}

Asamoah-Gyadu, J. Kwabena. 2005. African Charismatics: A Study of Independent Indigenous Pentecostalism in Ghana. Leiden: Brill.

Ashimolowo, Matthew. 2007. What Is Wrong with Being Black? Celebrating Our Heritage, Confronting Our Challenges. Shippensburg, PA: Destiny Image Publications.

Baëta, Christian G. 1962. Prophetism in Ghana: A Study of Some Spiritual Churches. London: SCM.

Cox, Harvey. 1995. Fire from Heaven: The Rise of Pentecostal Spirituality and the Reshaping of Religion in the Twenty-first Century. Reading, MA: Addison-Wesley Publishing Company.

Fernandez, James W. 1970. 'Rededication and Prophetism in Ghana,' Cahiers d'études africaines 10, no. 38: 228-305.

Gifford, Paul. 1995. The Christian Churches and the Democratization of Africa. Leiden: Brill.

Gifford, Paul. 2004. Ghana's New Christianity: Pentecostalism in a Globalizing African Economy. Bloomington \& Indianapolis: Indiana University Press.

Gifford, Paul. 2015. Christianity, Development and Modernity in Africa. London: Hurst.

Haar, Gerrie ter. 2006. 'The Role of Religion in Development: Towards a New Relationship between the European Union and Africa,' The European Journal of Development Research 18, no. 3: 351-367.

Miller, Donald E. and Tetsunao Yamamori. 2007. Global Pentecostalism: The New Face of Christian Social Engagement. Berkeley: University of California Press.

Otabil, Mensa. 1992. Beyond the Rivers of Ethiopia: A Biblical Revelation on God's Purpose for the Black Race. Accra: Altar International. 
50 J. Kwabena Asamoah-Gyadu

Ranger, Terence O., ed. 2008. Evangelical Christianity and Democracy in Africa. Oxford: Oxford University Press.

Turner, Harold W. 1979. Religious Innovation in Africa: Collected Essays on New Religious Movements. Boston: G.K. Hall.

Venter, David. 2004. Engaging Modernity: Methods and Cases for Studying African Independent Churches in South Africa. London: Westport, CT.

Walls, Andrew F. 1996. The Missionary Movement in Christian History: Studies in the Transmission of Faith. Maryknoll, NY: Orbis Books.

Walls, Andrew F. 2002. The Cross-Cultural Process in Christian History. Maryknoll, NY: Orbis Books.

Wariboko, Nimi. 2014. Nigerian Pentecostalism. Rochester, NY: University of Rochester Press. 


\title{
3 The challenge of environment and climate justice $^{1}$
}

\section{Imperatives of an eco-theological reformation of Christianity in African contexts}

\author{
Dietrich Werner
}

\section{Contexts: current challenges and debates on sustainability and the role of religions}

The issue of ecological transformation and eco-theology is not a new theme in African theological discourse. Already in 2008, the All African Conference of Churches (AACC) gave prominent space to the water and environmental crisis at its general assembly in Maputo. At that time the topic of the environment and spirituality came on the agenda when a cholera outbreak in Zimbabwe illustrated how pollution, environmental degradation and inadequate water supply were affecting people in Africa. The Maputo Covenant from that assembly stated: 'We affirm that earth keeping is a crucial dimension of the church's mission and we need to confess of the times when the church has been unfaithful in this mandate or at worst, acted and taught against' (World Council of Churches 2008). In this chapter I argue that facing the gravity of current and future environmental challenges for the African continent and its implications for forced migration both within and beyond the African continent needs to become a top priority in the new working period of AACC as in many African (as well as other) churches the seriousness of the environmental challenges has not yet been fully grasped. This chapter is structured along the following themes:

- contexts - current challenges and debates on sustainability and the role of religions;

- texts - resources for inspiring an ecological reformation of Christianity in Africa; and

- visions - imperatives for churches engaged in climate justice and ecological transformation.

A critical question at stake: is Christianity responsible for the environmental crisis in Africa?

A West African theologian once shared the following story based on his personal biographical experiences: 


\section{Dietrich Werner}

The village in the East of Ghana where I grew up was located close to a forest and a river. In the forest from ancient times onwards the ancestors live, therefore it was sacred. In the river there lived the spirit of the water, therefore it was sacred as well. Then people of my village became Christians. Now, according to the new Christian world view, there were no ancestors any more in the forest and also there were no spirits any more in the river. The taboos were disintegrating and disappearing. Instead the people started to make use and exploit both the forest and the water of the river for their own purposes. Today next to this village there is no forest left anymore and the river - it turned into a cesspool. Who has done a major mistake here? And for what reason?

(Emmanuel Anim of the Church of Pentecost, Ghana, story transmitted orally)

The key question embedded in this narrative is the following: Is the introduction of Christianity in Africa responsible for the environmental crisis? Is Christian tradition even the main root of environmental degradation?

This thesis is not new at all. Since the famous article written by Lynn White in 1967 'The historical roots of our ecological crisis', this perception has been reiterated by many scholars (e.g. Amery 1978; Münk 1987). White's article placed the blame for the ecological crisis on western Christianity as such. White's argument is that the Judeo-Christian doctrine of creation has led to the disenchantment of nature. Biblical religion has expelled the gods from the forests and streams once and for all. The biblical notion of 'dominion' of humankind over nature has given rise to western science which encouraged empirical investigation of the 'book of nature' and thus also promoted the spread of exploitative attitudes to nature. White argues that 'Christianity is the most anthropocentric religion the world has seen' $(1967,1205)$ and concludes that 'Christianity bears a huge burden of guilt'.

Several African scholars have taken up some elements of White's provocative thesis (although in-depth empirical research on the influence of the arrival of Christianity in the African continent on attitudes relating to nature and the environment has not yet been conducted). Harvey Sindima, for instance, following some of the arguments of Lynn White argues that the original and preChristian African concept is about 'the bondedness of life', a view based on the integral whole of life being interconnected with spiritual and material realms relating to each other. However, he argues that in the process of colonial expansion, this spiritual worldview which was traditionally dominant in African cultures was replaced and superseded by mechanistic worldviews originating by western enlightenment cultures of modernity (Sindima 1990).

Sindima concludes:

For some time the people of Africa have been influenced by a cosmology inherited from the West: the mechanistic perspective that views all things as lifeless commodities to be understood scientifically and to be used for 
human ends. Yet these people have an alternative way of looking at the world, an alternative cosmology, which can better serve their needs for cultural development and social justice in an ecologically responsible context. This alternative way might be called a life-centered way, since it stresses the bondedness, the interconnectedness of all living beings.

Thus, some African scholars like Sindima view the introduction of Christianity in Africa as a factor which weakened human ability to interpret and reconstruct the systems of values and norms that give meaning to the lives of Africans. But the belief that scientific progress was the way in which misery would be eliminated in the world by and large did not work out in reality. The alliance of progress, science and technology has not eliminated misery.

The recommendation therefore which Sindima and others are bringing is that African Christianity nowadays has to rediscover traditional African values and rethink Christianity in a non-western, African way. Thus, African eco-theologies embedded and implicitly articulated in African Initiated Churches potentially present an attractive, feasible and necessary way out of the ecological dilemmas presented by the current trends in African modern culture.

It is the key question of this chapter to see whether there are indeed traditional African worldviews incorporated in the life and worship traditions of African Initiated Churches, which have the potential of offering substantial solutions to the environmental challenges on the African continent or at least can offer motivational energies for ecological commitments and how their potential can be strengthened.

Even a quick look at current African theological discourses provides evidence that much more serious theological and empirical research is needed to deepen historical, systematic, cultural as well as ethical insights into the ecological assets of African Christianity. Although some major work has been done on the general relation between Christianity and eco-theology (Conradie 2006), empirical research on African Initiated Churches and their potential contribution for eco-ethics is still in its initial stage and we can only gather some very first insights and hints on this topic but can never explore this in full detail as the task is huge.

We first need to take into consideration that there have been other scholars who have seriously refuted and contradicted the thesis of White, that Christianity as such is the root cause of environmental degradation. Several scholars have accused him of overgeneralisation and oversimplification, historically and theologically. Scholars like this have argued

- that exploitative attitudes to nature have other causes and roots than just Christianity;

- that the biblical witness on relationships to nature cannot be reduced to just the dominium terrae tradition; 


\section{Dietrich Werner}

- that Christianity did not harmoniously pave the way to scientific and technological revolution as much of the Enlightenment traditions were achieved in struggling against Christianity;

- that White deals with Christianity indiscriminately, generalising all traditions of Christianity and failing to realise the only partial validity of his claims.

(Conradie 2016; Conradie et al. 2014, 120ff.)

The counter thesis to White's convictions expressed by many later scholars therefore reads: Christianity does have ecological wisdom traditions embedded in biblical witness and in the tradition of the church. Therefore, rightly interpreted, Christianity cannot be blamed as being the causa principalis of all of the global environmental crisis, but certainly is both part of the problem but also one major part of the solution to it - as it can offer major insights to ecological transformation and awareness-building from rereading ancient biblical tradition.

Christian traditions show some ecological ambiguity: some elements in Christianity have reinforced attitudes which can legitimate violent subjugation of nature and exploitative attitudes. Other traditions in Christianity and the Bible show admiration for the mystery of God's love in the beauty of creation and attitudes of care in solidarity with creation (Habel and Wurst 2001).

\section{Reading the signs of the time: the interrelatedness of environmental degradation, global climate and economic injustice, bad governance and unlimited power of transnational companies in African contexts}

In reading the contemporary context related to issues of environment and climate justice we need to take a look at actual challenges concerning the environmental situation in the African continent. It is often said that the African continent is the most religious continent in this world. However, it is also the poorest in terms of accessibility of livelihoods and the highest ranking in corruption and one of the continents most affected by land degradation and environmental pollution (Bounaim 2016). Why is this so?

The intersectionality of economic injustice, environmental destruction, bad governance and unlimited power of external transnational corporations (TNCs) certainly plays a significant role. It is striking and confusing to see that while the African Union (AU) adopted an African Convention on Nature and Natural Resources in 1968 (United Nations 1968), the legacy of colonial rule and the influx of transnational corporations and the lack of proper good governance and corporate political determination within the AU have so far prevented African governments from setting up proper and sufficient mechanisms to ensure that this crucial convention (updated in 2003; see African Union 2003) can be properly updated and that its provisions can be enforced and put into practice (Lubbe 2015). 
Clearly, protecting the environment of sub-Saharan Africa is an issue that needs to be examined more carefully and incorporated into an overall strategy of sustainable economic development (Nana-Sinkam 1995). Of particular urgency there are four major ecological challenges:

1 Loss of fertile soil and degradation of territories by erosion and draught (Nana-Sinkam 1995).

2 Reduction of rainfall, melting icecaps on Mount Kilimanjaro, river draining, drying out of major lakes (Mugambi 2016, 1117ff.).

3 Deforestation and loss of biodiversity (https://helpsavenature.com/ environmental-issues-in-africa, accessed 10 May 2019).

4 Dramatic reductions in local food production and application of land policies which encourage export of cash crops in African export countries while at the same time suffering internally from undernourishment (Mugambi 2016, 1124).

Once we take a general look at the ecological role of African's Christianity however, with regard to the Christian potential to counter environmental degradation and injustices, the result for some African authors seems rather meagre. The senior South African scholar Ernst Conradie has argued: 'In many contexts Christians are not environmental activists and environmental activists are not Christian' $(2011,158)$.

Obaji M. Agbiji (2015) has argued that faith communities in sub-Saharan Africa have only recently and gradually developed awareness of the dangers of ecological injustice and its connection with socioeconomic injustice. In many churches - at least observed in the Nigerian ecclesial community in particular not too much has yet been achieved with regard to developing a strong Christian ecological ideological orientation and activism which could stem the devastating impact of human beings on the environment.

\section{The ecumenical learning journey: from limits to growth towards a new concept of degrowth-oriented sustainability}

The first ever ecumenical definition of 'sustainability' as articulated in the WCC Bucharest 1974 conference is worth noting again:

The goal must be a robust, sustainable society, where each individual can feel secure that his quality of life will be maintained or improved. We can already delineate some necessary characteristics of this enduring society. First, social stability cannot be obtained without an equitable distribution of what is in scarce supply and common opportunity to participate in social decisions. Second, a robust global society will not be sustainable unless the need for food is at any time well below the global capacity to supply it, and unless the emissions of pollutants are well below the capacity of the ecosystem to absorb them. Third, the new social organization will be 
sustainable only as long as the rate of use of non-renewable resources does not outrun the increase in resources made available through technological innovation. Finally, a sustainable society requires a level of human activity which is not adversely influenced by the never ending, large and frequent natural variations in global climate.

(quoted in Vischer, n.d.)

In 2009 a major official statement on eco-justice and ecological debt was released by WCC which summarised some of the core convictions developed, bringing together the 'limits to growth' debate, the concept of 'just, participatory and sustainable societies' of the Nairobi assembly 1975 and the so-called AGAPE process (Alternative Globalization Addressing People and Earth) which followed in the 1980s: it summarised ecumenical key convictions, like that 'the era of "unlimited consumption" has reached its limits', that a new understanding of natural resources need to be developed which moved beyond labelling them simply as means of exploitation and that 'human existence is utterly dependant on a healthy functioning earth system' (World Council of Churches 2009).

\section{The political learning journey: the SDG agenda 2030 as both a political chance for sustainability concepts as well as a document of internal tensions}

Another element which needs to be mentioned in terms of shaping and influencing our current contexts for the purpose of articulating new visions for sustainability certainly is the UN Agenda for Sustainable Development (SDG Agenda).

The African Union in 2015 developed a similar vision, the Agenda 2063, which at least in its first major goal also mentions sustainability in talking about the vision of 'A prosperous Africa based on inclusive growth and sustainable development' (African Union 2015, 2).

The tracking process on Agenda 2063 and the Sustainable Development Goals published by United Nations Development Programme (UNDP), however reveals serious challenges ahead (African Union et al. 2017a). The most recent Executive Summary of the 2017 Africa Sustainable Development Report among several items points to three major results:

- slow progress made in reducing poverty and inequality owing to limited decent employment opportunities and weak social insurance mechanisms;

- rising food insecurity and undernourishment are a growing concern in Africa: some 355 million people in Africa were moderately or severely food insecure in 2015;

- globally, the proportion of fish stocks that are at biologically sustainable levels is declining.

It also states: 'Approximately six out of every ten SDG indicators cannot be tracked in Africa due to severe data limitations.' Therefore, particularly there 
are no data and trends available yet on a wide range of parameters pertaining to environmental sustainability. Dimension 7 in the AU Agenda 2063, which relates to 'Environmentally sustainable climate resilient economies and communities', does not have a clear set of indicators and reliable data yet on the African continent's level (African Union et al. 2017b).

This is deplorable, even more so as there is a fundamental tension and even contradictions between the socioeconomic and the ecological goals of the SDG Agenda. The fact that they are not harmonised yet indicates a hidden fundamental political ambiguity even within this most advanced UN Agenda and points to a hidden conflict within the global political discourse which centres around the concept of growth and sustainability: is the completion of major economic and social goals dependent on an unlimited increase of the exploitation of natural resources, or is the reduction of the use of natural resources the precondition for formulating more modest and less growth-oriented goals also for social and economic development (Wijkman, Weizsäcker and Club of Rome 2017, 90)?

It is here that the specific role of Christian Churches as well as other religious communities both within and beyond the African continent comes into play. This is because the SDG Agenda in the long run cannot be achieved without clarified concepts of sustainability and growth: governments are dependent on broad approval and motivation of the people to follow a paradigm shift in social development and ecological transformation. The moral and spiritual basis for a new concept of development can only come from bodies which reach deeper then secular governmental agencies, as fundamental values and spiritual orientations are at stake. Here is the task for an ecologically sensitised African Christianity to enter into serious political dialogue with the African Union (AU) and with other spiritual communities within Africa.

\section{Texts: resources for inspiring an ecological reformation of Christianity}

\section{The call for an ecological reformation of Christianity: rereading the reformation heritage as a protest movement against human greed and corruption}

In 2016, in the Greek Orthodox Academy of Volos, after an intensive conference of eco-theological experts from several different denominational traditions a 'Manifesto for an Ecological Reformation of Christianity' was published (World Council of Churches 2016). The Manifesto defines ecological reformation of Christianity, explicitly pointing to the reformation jubilee occasion celebrating its 500 years, as a comprehensive and long-term process:

Such an ecological reformation cannot be restricted to a recovery of a theology of creation or a call for responsible stewardship. It calls for reflection, discernment, prayer and a transformation of Christian practices that may be 
harmful to others, to all God's creatures. It also calls for a rereading of the canonical biblical texts, a critique of the environmental impact of specific Christian traditions and practices, a retrieval of historical insights, figures and practices, a reinvestigation of the content and significance of the Christian faith, a reconsideration of influential symbols, a renewal of Christian communities and a transformation of the ministries and missions of the church.

(Conradie, Werner and Tsalampouni 2016)

Thus:

the environmental crisis has therefore not only led to the claim that Christianity could and should make an important contribution to a more adequate understanding of the role of humanity in nature. It has also led to calls for a critical reassessment of the Christian faith itself.

(Conradie 2006, 65-66)

An ecological reformation of Christianity also takes up again an essential feature of the ecclesia semper reformanda est, which lives in the promise to be constantly renewed in spirit and in practical obedience. An ecological reformation of Christianity reminds us that classical reformation essentially was a liberation movement for the Gospel to be fully enacted and realised in its potential. European classical reformation was a protest and liberation movement against the combination of a religion of fear, superstition and idolisation of human greed and systemic spread of corruption. In a similar manner, today's ecological reformation of Christianity should liberate contemporary Christianity from becoming complicit in the cult of economic greed, unlimited material growth and structural violence against nature, animals and plants in the twenty-first century.

\section{Rereading key texts of ecological biblical hermeneutics: a different ecological understanding of the dominium terrae in Gen 1:28 and Gen 2:15}

If an ecological reformation of Christianity includes a reinvestigation of the content and significance of its most important sources, symbols and texts, this will certainly include key texts which up to the middle of the last century were predominantly read and used to justify the approach of dominance and subduing in western modernity, namely the creation narratives from Genesis. While the biblical witness on creation is much broader than just the creation narratives in the book of Genesis, it is obvious that an ecological reinterpretation of Gen 1:28 (to 'have dominion over the earth') is needed. While many authors argue that the dominium terrae is to be understood in the historical framework of an agrarian society and should not be interpreted in terms of domination or military conquest, but rather in terms of caring, protecting, nurturing, gardening, 
cultivating and serving (Conradie 2006, 77), others argue that the Hebrew term used $($ radah $=$ have dominion and kabash $=$ subdue $)$ cannot be completely pacified and does have some rather harsh connotations. However, as these Hebrew words and their understanding are rooted in kingship roles in the ancient Near East specific understanding needs to always be heard as well, that

the ruler has the responsibility for the well-being of the ones who are ruled over. The ruler (humans) therefore has the responsibility to protect the interests of the ruled (the other animals) with mercy and fairness. Although the provision is made for the use of force and violence, this may never cause the destruction of the community and solidarity between human and the other animals.

(Conradie 2006, 80)

It thus has become clear in extended exegetical discussions that the modern approach to nature in the process of industrialisation and mass exploitation can by no means be related or justified by the dominium terrae tradition of the creation narrative which is developed in a completely different cultural, historical and climate-related context.

Rereading texts with new ecological hermeneutics does not stop just with some key texts of the creation narratives. There have been new initiatives and exciting projects for an ecological rereading of biblical traditions both in African as well as Asian or European biblical scholarship which are worth noting and which encompass many different textual traditions of the Bible (Horrell 2012; Rao 2012). These are based and inspired by the conviction that God's interaction with creatures is not limited to humanity:

It is always an interaction with humanity in relation to the rest of creation and at times with other creatures to the exclusion of humanity. God's acts of creation, judgment and redemption embrace the earth and all its creatures.

(Conradie 2006, 83)

\section{Rereading Roman Catholic theological teachings: Laudato Si' as provocation for an eco-theological reformation of Christianity}

The encyclical letter of Pope Francis, Laudato Si' (Franciscus PP. 2015), can be regarded as the Magna Carta of a new integral ecological theology and one of the most courageous and outspoken critiques of the suicidal course of modernisation of humanity at present. It is unquestionably the most widespread, ecumenical and most radiating Christian call for a radical repentance which has reached out widely in UN circles and also into the fields of other world religions, for instance Muslim discourses. Laudato Si thus is a historic call for a radical ecological reformation of Christianity and much beyond. Laudato Si' includes a clear warning to all those responsible in world politics to overcome 
indifference and ignorance with regard to the primary victims of environmental degradation and to seriously change the basic patterns of development so as to move towards a more sustainable path of transformation as otherwise the very survival of humankind is endangered.

\section{Rereading indigenous African wisdom traditions: the concept of Christ the ecological ancestor and the notion of 'vital force' as starting point for an African eco-theology}

There is a debate in African theological discourses about what could provide a good cultural bridging point for linking African eco-theological considerations to elements in traditional African cultures and the spiritual African worldview. African community cultures have been strong in paying respect not only to living elders, but also to the seniority of ancestral spirits. Ancestors are involved in the very conception of life - family, clans, community, nature, the visible and the invisible worlds. Several authors have argued that in African cultural milieus Christ can be presented and understood also as ecological ancestor. Following Benezet Bujo or Charles Nyamiti, Kapya Kaoma has argued that ecotheological reflections in Africa would benefit by moving towards 'an African Missional Christology of Jesus as Ecological Ancestor' (2016, 159ff.). Based on the relevance of genealogies in biblical tradition where the ancestry is traced back several generations to indicate that all goes back directly to Abraham or to David, and bearing in mind that the ancestors stood for the promise of being rooted and blessed with the land and the fruits of nature, biblical passages receive a new meaning in eco-theological reflections which describe Jesus as the 'first born of all creation' (Col 1.17), which would make Jesus an elder brother to all that lives in creation (Kaoma 2016, 172). Also, the Gospel of John testifies to the ecological ancestry of Christ when it states: 'through him all things were made and without him, nothing was made' (John 1:3). Christ thus can be preached and confessed as a role model of providing care not just for human beings, but also for creation as a whole. If Christ is the ancestor of all creation, we cannot regard the human species as fundamentally different from nature, but all need to be viewed as ontologically related beings which live in a relationship of mutual interdependence and interconnectedness. Sin in ecological terms is no longer limited to human beings but extends to nonhumans in the universe (Kaoma 2016, 175).

In taking up the language of Christ the ecological ancestor it needs to be kept in mind however that the messianic language needs to be held together with the language of traditional wisdom: Christ is not only the one holding the cosmos together as the first fruit of a new creation, he is also the one to bring justice to creation. Overcoming the tension between a justice and sustainabilityrelated approach to eco-theology is what is demanded in African contexts. This also is what the South African Council of Churches (SACC) underlined in 2009 in trying to learn anew how mercy and loyalty, justice and peace are intimately connected (see Ps 85:10-11). 
In ecumenical documents on climate change, also from within the African context, climate change is typically regarded as an issue of justice and not only of sustainability. This is usually related to the observation that the current and the most likely future victims of climate change contributed least to the problem.

(Conradie 2010, 208)

Since climate change is a function of certain specific and distorted forms of production of wealth, it can only be addressed through economic transformation that will entail a redistribution of wealth. Therefore the most appropriate mechanisms for peaceful and mutually agreed redistribution mechanisms need to be clarified.

An interesting side debate in this perspective is related to the question of how to assess the role of Pentecostal Churches and theologies with regard to eco-theological stewardship and responsibility. Some scholars like Teddy Sakupapa $(2012$, 424) argue that 'the pneumatology of African Pentecostalism also tends to focus more on the individual quest for welfare much to the neglect of societal needs and the care of the earth' and therefore is not really conducive for an eco-theological transformation, but instead is contributing 'to the perpetration of capitalistic greed and the widening of the gap between the rich and the poor' (Ngong 2010). But there are also voices which argue that the original traditional African concept of the Spirit as a 'vital force' in nature can facilitate more dialogue between African pneumatology and the eco-theological discourse. Teddy Sakupapa has convincingly argued:

In light of the conceptual framework of vital force therefore, it can be argued that the Holy Spirit will be understood as the vital force and life that is common to all. In other words, the Spirit's presence will be recognised in the whole of creation in a panentheistic sense. This perspective is particularly important in getting African Christians and churches involved in ecological work. In fact, in African cosmology, the sacredness of nature is derived from nature's relationship with the creator whose vital force has animated nature. Humans are therefore in an ontological relationship with nature given their common descent from the creator. A pneumatological understanding of vital force enhances this ontological relationship.

$(2013,428)$

\section{Rediscovering the missio Creatoris Dei: bringing together sources and insights from Orthodox, feminist and Pentecostal traditions}

Kapya Kaoma has stated repeatedly that the very understanding of mission of the church as missio Dei has to be enlarged and put into an ecological universal context: Christian mission is not church or human centred, but God centred. But as God is concerned about the whole of the universe and not just about the human being, also the understanding of his mission has to be liberated from 


\section{Dietrich Werner}

anthropocentric reductionism. If Christian mission is joining God in proclaiming and performing God's rule on earth, then the church's mission is related to the mission of Christ (mission Christi), empowered by the mission of the Spirit (mission Spiritus), but at the same time participating and related to what God is doing already in the midst of his creation, which he did not cease or leave behind, the missio Creatoris Dei, his loving and caring for all that lives in creation (Kaoma 2016). A Trinitarian approach to missio Dei, understood as missio Creatoris Dei, according to Kapya Kaoma can lean on very important witnesses of faith as included in biblical tradition as well as in church hymns (e.g. Ps 19:1-4).

Once we ask which theological traditions in African Christianity have mainly supported this view of a missio Creatoris Dei and the work of the Holy Spirit in the whole of the universe we find significant evidence for a crucial support of an eco-theological reformation of African Christianity particularly from some of the predominantly marginal church or theological traditions, i.e. Orthodox, feminist, Independent and Pentecostal church traditions. Some of these church traditions - while no generalisation is possible - significantly seem to contribute to broadening an understanding of the ongoing activity of God's Spirit in the midst of the universe - though this does by no means imply that other church traditions have nothing to offer in terms of eco-theological expertise and wisdom. There are some clear hints to a cosmological understanding of mission also in some recent conceptualisations of African as well as evangelical missiology (see, e.g. Bosch 1991; Samuel and Sugden 1999; Walls and Ross 2008). It might be important to bring together and to assess the different learning streams and renewal movements within African Christianity with regard to their potential contribution to a new sense of awe, wonder, respect and responsibility to the beauty of creation:

- Ancient Orthodox church traditions in Africa like the Ethiopian, Coptic or Eritrean Oriental Orthodox traditions have an understanding for indwelling activity of the Holy Spirit in Creation as well as a respect for regular fasting traditions as well as the blessings of water and with it all of creation which also have a profound significance for the relation of human beings to nature and the ecological integrity (Orthodox Christian Network 2016).

- Feminist theological circles in Africa stress the female characteristics of God and the works of the Holy Spirit which contradicts patriarchal patterns of rule and oppression against women as well as against nature. The discourses about human sexualities, alternative masculinities as well as the human body have also contributed to the search for new attitudes to nature within the environmental challenges at hand (see, e.g. Dube 2015; Masenya 2010; Siwila 2014).

- Marthinus L. Daneel has argued that African Independent Churches are potential 'Vehicles of Earth-Care in Africa' (Daneel, n.d.; 2006) and Öhlmann, Frost and Gräb (2016) have added significant research insights on African Initiated Churches to be regarded as significant development 
actors and potential partners of development cooperation in Germany. We will look at one case study in more detail in the last section.

There is a more conflictive or ambivalent and divergent view on the ecotheological openness and contribution of African Pentecostal theological traditions: there are also some important voices to argue that African Pentecostalism has a potential to become a major contributing factor to ecological awarenessbuilding on the African continent (Sakupapa 2012). But other voices like Ben-Willie Kwaku Golo (2013) argue that Pentecostalism first needs to rethink the traditional understanding of salvation in African Christianity which in many cases follows the notion that the divine restorative plan is creationsin-redemption, which for many centuries also dominated the western church. To become more open to the eco-theological movement Pentecostalism instead needs to be guided by the earlier notion and sequence of a creation-incarnationrecreation divine restorative plan, which was the way the early church understood God's redemptive plan, as it centred on Jesus Christ and the victory of the Redeemer-Creator God in Jesus (Golo 2013). Only with an approach taken from a Trinitarian concept of missio Creatoris Dei could the prevailing ecological negligence in parts of African Christian salvation theology and the related divorce between creation and salvation be overcome.

The ambivalent picture regarding the eco-theological relevance and openness of African Pentecostalism might be summarised in voices such as Chammah Kaunda, who stated that African Pentecostalism still has a major task to become fully engaged with ecology and with eco-theological reflection. While there is a remarkable new Pentecostal scholarship in the area of eco-theology emerging on a global scale (Studebaker 2008; Swoboda 2013; Yong 2011) we are still lacking more prominent and younger scholars to come up with new African Pentecostal theological outlines and conceptualisations to really make an impact on Pentecostal African Christianity. The need for training faith leaders in eco-spiritualities is obvious all around but taken up systematically only by very few institutes in Africa so far.

\section{Visions: imperatives for churches engaged in climate justice and ecological transformation}

\section{The greening of churches: local churches as laboratory for learning sustainable and environmentally responsible lifestyles}

Ecological transformation starts with changes in attitudes, awareness and daily practices in local places. The churches have the advantage that they have thousands of local congregations which assemble regularly. Each of them usually has a place which is relevant for a larger group and therefore has an educational function as well. Church courts, church-related cemeteries, church buildings are ecological learning centres. In several countries 'green church' networks have emerged which bring local churches together which have similar standards to 
commit themselves to learning about environmentally sound and transparent ways of living. Some have developed detailed guidelines about how to provide ecologically sensitive care for church premises (Eco-Congregation Scotland 2011). While these initiatives can provide important incentives to do something in one's own backyard these initiatives need to maintain a clear focus on the interrelatedness of justice and ecological concerns.

There are some examples from the African continent as well where churches have started green church learning projects, like in the Diocese of the Anglican Church of Swaziland and African Methodist Episcopal Church (Ncumisa 2017). There is an impressive Southern African Eco-Congregations network which is promoted by SAFCEI, the South African Faith Communities Environment Institute (https://safcei.org/about-us). But an association of African green churches on the whole of the continent which could encourage earth spiritualities to be developed in different contexts does not yet seem to exist. A full-scale African theology of environmental stewardship as a joint project of churches on the African continent is still a vision to be implemented and worked for (Beisner et al., n.d.).

\section{Interrupting the cycle of unlimited consumerism: rediscovering the value of ancient practices of fasting and praying}

In Christian as well as in Muslim traditions in Africa there is a widespread knowledge alive in terms of traditions of regular fasting periods, which have a profound implication for sustainable lifestyles and eco-theological awarenessbuilding.

Fasting has been an ancient practice in all of Christianity, which held regular fasting days traditionally each Wednesday and Friday (still preserved in Orthodox Christianity also in Africa). This aimed at a regular interruption of the cycles of violence against nature and in society as well as a period of preparation for prayer and for meditating the journey of Christ to the Cross. The regular exchange of periods of fasting and consumption can contribute today to an attitude of respect and appreciation for nutrition and healthy food as well as cultivate a sense of solidarity and listening to those who have nothing to eat. In many of the African Initiated Churches fasting also plays a big and visible role in spiritual disciplines. The common fasting period of 40 days before Easter is currently experiencing a renaissance also in western Christianity, where different forms of fasting are practised to get rid of bad habits and to become less addicted to items which modern consumerism offers to people. Fasting is traditionally always related to repentance, to generosity, to prayer and other ways of strengthening inner spiritual disciplines (Berghuis 2007).

Increasingly there are initiatives and campaigns to link Christian fasting practices with ecological concerns, even with carbon-fasting ('A Lenten Fast, from Carbon and from Pride. Our Eco-Inspired Lenten Practices Can Save Souls and Eco Systems', 2017; see also https://catholicclimatemovement.global/fast-2). The international Fast for the Climate Movement started in 2013 and is gaining 
more followers every year: people are fasting each first day of the month in order to stand in solidarity with vulnerable people who are most affected by dangerous climate impacts. 'By choosing not to eat on the first day of every month, a growing movement of fasters including many youth groups, environmentalists and faith communities, is calling for world leaders to act to stop the climate crisis' (www.climatenetwork.org/fastfortheclimate).

\section{The Eucharist as a multidimensional earth healing process: healing of God, healing of human community, healing of the earth}

Another meaningful development is reported mainly from Zimbabwe, where under the auspices of the Zimbabwean Institute of Religious Research and Ecological Conservation, two religiously distinct movements - the Association of Zimbabwean Traditionalist Ecologists and the Association of African Earthkeeping Churches - joined forces in the 1980s to wage a new chimurenga, a struggle for the liberation of creation, particularly the rehabilitation of the degraded environment of Zimbabwe's overcrowded communal lands, under the banner 'war of the trees' (Daneel 2006). In the early 1980s, the movement Daneel started in Zimbabwe planted around 15 million trees, produced 100,000 seedlings per year, and mobilised a 'green army' seeking to heal the land and the population after the devastation of war (Daneel, n.d.). This involved planting trees, conserving land, forging peace, seeking reconciliation and encouraging forgiveness. The earth-and-people-healing ministry provided new impetus and direction to church life and mission, as well as numerical church growth. These churches excel in developing original, contextualised theologies at the grass roots of African society (Daneel and Hill 2016). A 'Network of Earthkeeping Christian Communities in South Africa' emerged (Daneel 2007; Davies 2006).

This understanding has generated a tree-planting Eucharist in an attempt to integrate creation into the body of Christ.... The central argument among proponents of a tree-planting Eucharist is that the body of Christ is more than the church. The concept also includes relationships with all creation: 'For by him all things were created ... in him all things hold together ... and through him to reconcile to himself all things' (Colossians 1:16-20).

(Masika 2012)

Liturgically, the tree-planting accompanies the Eucharist, but does not replace the core of the sharing of the Eucharistic elements. The preparation of an earthhealing Eucharist begins with the digging of holes for planting trees in the church compound. The site is sometimes called 'The Lord's Acre'. The sacrament itself is introduced by public confessions of ecological sins, such as random tree-felling, causing soil erosion through riverbank cultivation and the use of sledges, etc., under the guidance of Spirit-filled prophets. Seedlings are placed on the communion table along with the bread and wine. After public confession of ecological sins, participants line up and file past the table picking up a 
seedling and partaking of the elements. Each participant then proceeds to the prepared holes, where the bishop sprinkles holy water on the ground and says liturgical words of blessings for the seedlings, for the water and for the soil. Thus, elements of nature are organically integrated into an earth-healing Eucharistic service which is quite meaningful (Masika 2012, 3ff.).

We have no reliable information on how far this has spread and whether it is still continued (together with SAFCEI in South Africa several regional initiatives are known which support tree-planting initiatives, see http://safcei.org/ tag/tree-planting). But there are reports that also the Baptist mission of Kenya has taken up some of these enlarged Eucharistic liturgies: seeing the rapid disappearance of indigenous trees and forests as an opportunity for churches it has developed a tree-planting culture across Kenya, in order to bring a Christian perspective to bear on environmental concerns in East Africa.

The tentative thesis presented here is the conviction that African Initiated Churches, while often not having a formal and visible focus on ecology yet, do have the potential for mobilising for new eco-theological awareness and ecological reformation of African Christianity. This is not only because their members are often on the frontline of those bearing the consequences of western or African waste disposal practices and environmental degradation, but also because in their liturgies, theologies as well as in some initiation rites, there are elements of traditional African wisdom embedded which point to a much closer relationship between nature and humankind than in other forms of western Christianity.

But we need more empirical research on the reality of African Initiated Churches in order to arrive at a more substantial assessment of their actual role with regard to establishing an ecological mind shift in African societies and churches in general: can the growth of African Initiated Churches particularly in Southern Africa be understood as a sign and symptom of the resistance of African Christianity to becoming submerged into the mindset of traditional western enlightenment worldviews and instrumentalist interpretation of the dominium terrae? Is the return to traditional spiritual worldviews and the perception of nature as a realm of the sacred, the spirits and the ancestors which is held in many of the African Initiated Churches, a relevant, a sufficient or even the only possible solution to the environmental crisis on the African continent? Or does it present at least a significant contribution for the Christian response to the environmental crisis in Africa? While we would assume that there are significant potentials and assets in terms of environmental ethics and responsible stewardship in African Initiated Churches, we ought to be careful not to romanticise and idealise just one type of African churches in this regard. What determines the life of young people in Africa today are not just traditional and indigenous African values, but with more powerful influence certainly also values of modernity, smartphone culture, and forces of individualisation and consumerism. It appears to be a more realistic assessment of the situation to argue that only the complementary role of common efforts of all African churches and the different types and denominational streams will be able to 
achieve a solid and continent-wide impact in changing the value systems and strengthening ecological stewardship and responsibility for the future of African nations for the decades to come.

\section{Theologising about what we leave behind: towards a prophetic- critical garbage theology}

What is not yet really developed and might also be new in African contexts is the concern for a garbage theology. It is interesting to look at the state of our civilisation from the end of it, i.e. from the perspective of what ends in the waste disposal bags, in the landfills, in the dumpsites. It sheds light on our values, priorities and consumption patterns. In the garbage can or landfill we see evidence of our insatiable desire for convenience, our indifference to the other (both human and nonhuman), the reflection of our throwaway and short-use cycles culture and our personal laziness.

There is a growing awareness also in the political sector in African nations of the urgency for proper waste disposal management systems (Roberts 2014). Africa's pressing need for waste management is a topic which is being discussed (Kaledzi 2017). The phenomenon of plastic waste deposits which are carried by major streams into the world's oceans causing millions of animal deaths at sea is well known and increasingly researched (McGrath 2017).

While the difficulties for proper waste disposal management and garbage recycling are global, apparently there have been minimal efforts to develop a contextually relevant theology of waste disposal or an ecologically sensitive theology of recycling. It is in this area that the concern for ecology and the concern for the marginalised and urban poor are very closely linked with each other (see as an exception from African contexts De Beer 2014). There are some promising examples of prophetical theologians trying to do theology from the context of garbage dumping sites and in solidarity with those who have to work on garbage sites (Freund 2014).

\section{Environmental implications of global meat production: towards a global nutrition transition}

A final area where some imperatives for churches to become engaged in climate justice and ecological transformation needs to be reflected is the huge increase in global meat production, which has vast implications for the continuation of global climate change: worldwide meat production has tripled over the last four decades and increased 20 per cent in just the last ten years. Meanwhile, industrial countries are consuming growing amounts of meat, nearly double the quantity consumed in developing countries - this is one of the gravest areas in which injustice and inequality are obvious in today's economic systems. Largescale meat production has serious implications for the world's climate. Animal waste releases methane and nitrous oxide, greenhouse gases that are 25 and 300 times more potent than carbon dioxide, respectively ('Global Meat Production 
and Consumption Continue to Rise', n.d.). Thus the landscapes and data of global meat consumption and production is an area in which both the global threats of unhealthy nutritional standards as well as the grave injustices between some countries in the North and some countries in the South become apparent.

It is not just an average increase in meat production and consumption which is taking place, but there is evidence of a rising number of people suffering from overconsumption of meat and malnutrition, leading for example to obesity (DeCapua 2012).

The model of mirroring and repeating the development models and modernisation patterns of western countries by linking progress and well-being to excessive patterns of meat consumption is at work here with some fatal and disastrous consequences in the long run. The United Nations forecasts demand for meat, milk and eggs in Africa will almost quadruple by 2050 , fuelled by a ballooning population - expected to double to 2.4 billion - and a growing appetite for high-protein foods driven by rising living standards. It is therefore asked by experts: 'Can Africa deal with an expected boom in demand for meat?' (Bacchi 2017).

Scholars and experts in WHO now speak of the global nutrition transition and the pandemic of obesity in developing countries (Popkin et al. 2012). Is there a way for the African development paradigm and model for a sustainable future to disconnect and delink the notion of progress and well-being or prosperity from excessive rates of meat consumption? This is an interesting topic as some tensions might also be faced where values of traditional African cultures might also clash with ecological considerations so that here we might have an area where in some cases also traditional African values and traditions are contrary to modern ecological imperatives. For instance, there are interesting debates about meat consumption and healthy lifestyles in Maasai ethnic communities (Berg Petersen 2012; Kuhnlein et al. 2009, ch. 11).

It has become clear that a change in nutritional values and attitudes will be required both in western and African countries, related to the envisioned global nutrition transition, some of which might be in conflict with traditional African values and customs. But it is the task and mandate of the churches to transform values, lifestyles and patterns of behaviour, even to the extent that this might clash with traditionally held perceptions so as to reflect properly the values of the Kingdom of God and life to be shared with all - including the future generations on this earth.

\section{Note}

1 The following is the abbreviated version of a longer lecture which was delivered during the 11th General Assembly of the All Africa Conference of Churches, July 2018 in Kigali, Rwanda, in its African Theological Institute. 


\section{References}

'A Lenten Fast, from Carbon and from Pride. Our Eco-Inspired Lenten Practices Can Save Souls and Eco Systems'. 2017. Catholic Ecology. 28 February 2017. https://catholic ecology.net/blog/lenten-fast-carbon-and-pride.

African Union. 2003. 'African Convention on the Conservation of Nature and Natural Resources'. Maputo, Mozambique.

African Union. 2015. 'Agenda 2063. The Africa We Want'. Addis Ababa: African Union Commission.

African Union, Economic Commission for Africa, African Development Bank, and United Nations Development Programme, eds. 2017a. 2017 Africa Sustainable Development Report: Tracking Progress on Agenda 2063 and the Sustainable Development Goals. Addis Ababa: UNDP Publications Section.

African Union, Economic Commission for Africa, African Development Bank, and United Nations Development Programme, eds. 2017b. 2017 Africa Sustainable Development Report: Tracking Progress on Agenda 2063 and the Sustainable Development Goals (Executive Summary). Addis Ababa: UNDP Publications Section.

Agbiji, Obaji M. 2015. 'Religion and Ecological Justice in Africa: Engaging "Value for Community" as Praxis for Ecological and Socio-Economic Justice'. HTS Teologiese Studies/Theological Studies 71, no. 2. https://doi.org/10.4102/hts.v71i2.2663.

Amery, Carl. 1978. Das Ende Der Vorsehung: Die Gnadenlosen Folgen des Christentums. Reinbek bei Hamburg: Rowohlt.

Bacchi, Umberto. 2017. 'Can Africa Deal with an Expected Boom in Demand for Meat?' Reuters. 13 March, 2017. www.reuters.com/article/us-africa-food-livestock-idUSKBN 16K1V3.

Beisner, E. Calvin, Michael Cromartie, Thomas Sieger Derr, Diane Knippers, P. J. Hill, and Timothy Terrell. n.d. 'A Biblical Perspective on Environmental Stewardship'. Acton Institute. Accessed 17 April 2019. https://acton.org/public-policy/environmentalstewardship/theology-e/biblical-perspective-environmental-stewardship.

Berg Petersen, Irene. 2012. 'The Maasai Keep Healthy Despite a High-Fat Diet'. sciencenordic.com. 11 September 2012. http://sciencenordic.com/maasai-keephealthy-despite-high-fat-diet.

Berghuis, Kent. 2007. Christian Fasting - A Theological Approach. Biblical Studies Press 2007.

Bosch, David J. 1991. Transforming Mission: Paradigm Shifts in Mission. London: Orbis Books.

Bounaim, Najia. 2016. 'Africa Faces Some Serious Environmental Problems: Greenpeace'. Globe Afrique - Africa and World News, 15 November 2016. https://globeafrique.com/africa-faces-some-serious-environmental-problems-greenpeace/.

Conradie, Ernst M. 2006. Christianity and Ecological Theology: Resources for Further Research. Study Guides in Religion and Theology. Stellenbosch: SUN Press.

Conradie, Ernst M. 2010. 'Justice, Peace and Care for Creation: What Is at Stake? Some South African Perspectives'. International Review of Mission 99, no. 2: 203-218. https:// doi.org/10.1111/j.1758-6631.2010.00044.x.

Conradie, Ernst M. 2016. 'Penultimate Perspectives on the Root Causes of Environmental Destruction in Africa'. Scriptura 115: 1-19. https://doi.org/10.7833/115-0-1279.

Conradie, Ernst M. 2011. 'The Church and the Environment: Seven Stations towards the Sanctification of the Whole Earth'. Scriptura 107: 156-170. https://doi.org/ 10.7833/107-0-133.

Conradie, Ernst M., Sigurd Bergmann, Celia Deane-Drummond, and Denis Edwards, eds. 2014. Christian Faith and the Earth: Current Paths and Emerging Horizons in Ecotheology. London: Bloomsbury. 


\section{Dietrich Werner}

Conradie, Ernst M., Dietrich Werner, and Ekaterini Tsalampouni, eds. 2016. 'Manifesto for an Ecological Reformation of Christianity. The Volos Call March 2016'. Accessed 17 April 2019. www.globethics.net/documents/4289936/18906251/EcoTheol_Volos_ Manifesto + on + an + ecological ++ reformation + of + all + Christian+traditions+31Marc h2016.pdf/e6ed7cc8-3fc4-4cbb-82c6-52c90f3f7492.

Daneel, Marthinus L. n.d. 'African Earthkeeping Churches - Association of (Zimbabwe)'. University of Florida, College of Liberal Arts and Sciences. Accessed 17 April 2019. http://users.clas.ufl.edu/bron/pdf-christianity/Daneel-African\%20Earthkeeping\%20 Churches.pdf.

Daneel, Marthinus L. 2006. 'African Initiated Churches as Vehicles of Earth-Care in Africa'. In The Oxford Handbook of Religion and Ecology, edited by Roger S. Gottlieb. Oxford University Press. https://doi.org/10.1093/oxfordhb/9780195178722.001.0001.

Daneel, Marthinus L. 2007. 'Holistic African Theology - Enacted in Rural Zimbabwe'. Center for Global Christianity and Mission News 3: 1-6.

Daneel, Marthinus L., and Graham Hill. 2016. 'The Growth and Dynamism of African Initiated Churches and African Earthkeeping Movements'. The Global Church Project. 15 December 2016. https://theglobalchurchproject.com/video/m-1-daneel-growthdynamism-african-initiated-churches-african-earthkeeping-movements/.

Davies, Geoff. 2006. 'Network of Earthkeeping Christian Communities in South Africa Update: December 2006'. Accessed 17 April 2019. www.givengain.com/unique/kga/ upload/2006neccsadec.pdf.

De Beer, Stephan. 2014. 'Jesus in the Dumping Sites: Doing Theology in the Overlaps of Human and Material Waste'. HTS Teologiese Studies/Theological Studies 70, no. 3. https://doi.org/10.4102/hts.v70i3.2724.

DeCapua, Joe. 2012. 'Developing Countries See Sharp Rise in Meat Consumption'. voanews.com. 28 March 2012. www.voanews.com/a/decapua-farm-animals-29mar12144898655/179917.html.

Dube, Musa W. 2015. “"And God Saw That It Was Very Good”: An Earth-Friendly Theatrical Reading of Genesis 1'. Black Theology 13, no. 3: 230-246. https:/doi.org/ 10.1179/1476994815Z.00000000060.

Eco-Congregation Scotland. 2011. 'Ideas for Action - Greening Church Buildings'. 29 March 2011. www.ecocongregationscotland.org/materials/ideas-for-action/practicalliving/greening-the-cornerstone/.

Franciscus PP. [Jorge Mario Bergoglio]. 2015. Encyclical Letter Laudato Si' of the Holy Father Francis on Care for Our Common Home. Vatican Press.

Freund, John. 2014. 'Doing Theology in a Garbage Dump'. FAMVIN News. 24 October 2014. https://famvin.org/en/2014/10/24/doing-theology-in-a-garbage-dump/.

'Global Meat Production and Consumption Continue to Rise'. n.d. worldwatch.org. Accessed 17 April 2019. www.worldwatch.org/global-meat-production-and-consumptioncontinue-rise.

Golo, Ben-Willie Kwaku. 2013. 'Redeemed from the Earth? Environmental Change and Salvation Theology in African Christianity'. Scriptura 111: 348-361. https://doi. org/10.7833/111-0-17.

Habel, Norman C., and Shirley Wurst, eds. 2001. The Earth Story in Wisdom Traditions. Sheffield: Sheffield Academic Press.

Horrell, David G. 'Is the Bible Green? Reading Scripture Ecologically'. 14 September 2012. http://ecocongregationireland.com/archives/3632. 
Kaledzi, Isaac. 2017. 'Africa's Pressing Need for Waste Management'. dw.com. 10 July 2017. www.dw.com/en/africas-pressing-need-for-waste-management/a-39623900.

Kaoma, Kapya. 2016. 'From Missio Dei to Missio Creatoris Dei. Toward an African Missional Christology of Jesus as the Ecological Ancestor'. In Eco-Theology, Climate Justice and Food Security Theological Education and Christian Leadership Development, edited by Dietrich Werner and Elisabeth Jeglitzka. Geneva: Globethics.

Kuhnlein, Harriet V., Bill Erasmus, Dina Spigelski, and Food and Agriculture Organization of the United Nations, eds. 2009. Indigenous Peoples' Food Systems: The Many Dimensions of Culture, Diversity and Environment for Nutrition and Health. Rome: Food and Agriculture Organization of the United Nations.

Lubbe, Willem Daniel. 2015. 'We Need a New Convention to Protect Africa's Environment'. The Conversation. 7 May 2015. http://theconversation.com/we-need-a-newconvention-to-protect-africas-environment-40648.

Masenya, Madipoane. 2010. 'All from the Same Source? Deconstructing a (Male) Anthropocentric Reading of Job (3) through an Eco-Bosadi Lens'. JTSA 137: 46-60.

Masika, Joseph Kisoi. 2012. 'Doing Ecology with African Creation Wisdom'. Didache: Faithful Teaching 12, no. 1.

McGrath, Ciaran. 2017. 'India, Africa and China Blamed for $90 \%$ of Plastic Waste Choking Our Oceans'. Express.co.uk. 12 December 2017. www.express.co.uk/news/ world/891361/Plastic-waste-pollution-90-per-cent-rivers-India-China-Africa.

Mugambi, Jesse. 2016. 'Climate Change and Food Security: A Challenge for African Christianity'. In Anthology of African Christianity, edited by Isabel Apawo Phiri, Dietrich Werner, Chammah Kaunda, and Kennedy Owino. Oxford: Regnum Books International.

Münk, Hans J. 1987. 'Umweltkrise - Folge und Erbe des Christentums? HistorischSystematische Überlegungen zu einer Umstrittenen These im Vorfeld Ökologischer Ethik'. JCSW 28: 133-206.

Nana-Sinkam, S.C. 1995. 'Land and Environmental Degradation and Desertification in Africa'. Rome: Food and Agriculture Organization of the United Nations.

Ncumisa [pseud.]. 'Diocese of Swaziland and African Methodist Episcopal (AME) Church Going Green'. Green Anglicans, 23 August 2017. www.greenanglicans.org/ diocese-of-swaziland-and-african-methodist-episcopal-ame-church-going-green/.

Ngong, David Tonghou. 2010. The Holy Spirit and Salvation in African Christian Theology: Imagining a More Hopeful Future for Africa. New York: Lang.

Öhlmann, Philipp, Marie-Luise Frost, and Wilhelm Gräb. 2016. 'African Initiated Churches' Potential as Development Actors'. HTS Teologiese Studies/Theological Studies 72, no. 4. https://doi.org/10.4102/hts.v72i4.3825.

Orthodox Christian Network. 2016. 'Fasting, The Orthodox Christian Way'. 18 March 2016. http://orthochristian.com/91690.html.

Popkin, Barry M., Linda S. Adair, and Shu Wen Ng. 2012. 'Global Nutrition Transition and the Pandemic of Obesity in Developing Countries'. Nutrition Reviews 70, no. 1: 3-21. https://doi.org/10.1111/j.1753-4887.2011.00456.x.

Rao, Chilkuri Vasantha. 2012. Animal Rights and Animal Laws in the Bible: The Daily Practice of Reverence for Life. Lewiston: The Edwin Mellen Press.

Roberts, Bruce. 2014. 'Plastic Waste Management in Africa'. Presentation held at the Conference of the Society for Applied Anthropology at Albuquerque, New Mexico. Accessed 17 April 2019. https://doi.org/10.13140/rg.2.1.2837.2320.

Sakupapa, Teddy Chalwe. 2012. 'Spirit and Ecology in the Context of African Theology'. Scriptura 111, no. 3. https://doi.org/10.7833/111-1-12. 


\section{Dietrich Werner}

Samuel, Vinay and Chris Sugden. 1999. Mission as Transformation: A Theology of the Whole Gospel. Oxford: Regnum Books International.

Sindima, Harvey. 1990. 'Community of Life: Ecological Theology in African Perspective'. In Liberating Life: Contemporary Approaches to Ecological Theology, edited by Charles Birch, William Eakin, and Jay Byrd McDaniel, 137-147. Maryknoll, NY: Orbis Books.

Siwila, Lilian Cheelo. 2014. "Tracing the Ecological Footprints of Our Foremothers': Towards an African Feminist Approach to Women's Connectedness with Nature'. Studia Historiae Ecclesiasticae 40, no. 2: 131-147.

South African Council of Churches (SACC). 2009. Climate Change: A Challenge to the Churches in South Africa. Marshalltown, South Africa: South African Council of Churches. https://acen.anglicancommunion.org/media/61434/climate_change_churches_ in_sa.pdf.

Studebaker, Steven M. 2008. 'The Spirit in Creation: A Unified Theology of Grace and Creation Care'. Zygon 43(4): 943-960. https://doi.org/10.1111/j.1467-9744.2008.00970.x

Swoboda, A. J. 2013. Tongues and Trees: Towards a Pentecostal Ecological Theology. Blandford Forum, Dorset: Deo Publishing.

United Nations. 1968 [Registered 31 March 1976]. 'African Convention on the Conservation of Nature and Natural Resources (with Annexed List of Protected Species)'. United Nations Treaty Series 1001, no. I-14689.

Vischer, Lukas. n.d. 'The Theme of Humanity and Creation in the Ecumenical Movement'. Accessed 17 April 2019. www.jaysquare.com/resources/growthdocs/grow10b.htm.

Walls, Andrew F., and Cathy Ross, eds. 2008. Mission in the Twenty-First Century: Exploring the Five Marks of Global Mission. Maryknoll, N.Y.: Orbis Books.

White, Lynn. 1967. 'The Historical Roots of Our Ecologic Crisis'. Science 155, no. 3767: 1203-7. https://doi.org/10.1126/science.155.3767.1203.

Wijkman, Anders, Ernst Ulrich von Weizsäcker, and Club of Rome, eds. 2017. Wir sind dran: Was wir ändern müssen, wenn wir bleiben wollen. Gütersloh: Gütersloher Verlagshaus.

World Council of Churches. 2008. 'African Christians Highlight Water and Environmental Crises'. 18 December 2008. www.oikoumene.org/en/press-centre/news/africanchristians-highlight-water-and-environmental-crises.

World Council of Churches. 2016. 'Conference Calls for Ecological Reformation of Christianity'. 7 April 2016. www.oikoumene.org/en/press-centre/news/conferencecalls-for-ecological-reformation-of-christianity.

World Council of Churches. 2009. 'Statement on Eco-Justice and Ecological Debt'. 2 September 2009. www.oikoumene.org/en/resources/documents/central-committee/ 2009/report-on-public-issues/statement-on-eco-justice-and-ecological-debt.

Yong, Amos. 2011. The Spirit of Creation: Modern Science and Divine Action in the Pentecostal-Charismatic Imagination. Pentecostal Manifestos. Grand Rapids, Michigan: W.B. Eerdmans Pub. Co. 


\title{
4 African Initiated Churches and development from below
}

\author{
Subjecting a thesis to closer scrutiny
}

\author{
Ignatius Swart
}

\section{Introduction}

In the burgeoning academic scholarship on religion and development, most specifically that section concerned with the nexus between religion and development in African society, the potential and actual development role of African Initiated Churches (AICs) - or what some scholars would like to refer to in the collective sense as 'African Independent faith' (Schlemmer 2008, 19), '(African) Independent Christianity' (Bompani 2010), or 'African Christianities' (Adogame 2016) - is receiving increasing attention. In this respect, a very specific theoretical claim or thesis that has come into vogue in the literature to capture the essential contribution that these churches are making in the sphere of development is that of development from below. By adopting this thesis scholars are advancing an elaborate argument about a mode of development that - in terms of process, agency and outcome - can be proffered as a counterpoint to a development dynamic from above driven by the state and international development agencies. In the wake of the failure of these institutions to bring about sustainable and lasting development outcomes in poor African communities, AICs are increasingly appreciated as emerging catalysts of endogenous, popular, or grass-roots development that may even have the potential to ripple outwards to become the driving force of an 'African Renaissance' (Bernstein and Rule 2010, 126). In effect, development is here perceived as a dynamic whereby local people and groups are not only taking charge of their own development, but whereby the interrelated religious and cultural dimensions of their life worlds become important mediating factors in terms of improving the nature and outcome of their development (Adogame 2016, 2-3).

This chapter seeks to contribute to the academic debate about the AICs and development by subjecting the development-from-below thesis to closer scrutiny. With this aim in mind, it is important to mention that the chapter has been written within the collaborative framework provided by the Research Programme on Religious Communities and Sustainable Development at Humboldt-Universität zu Berlin and the programme's latest research project on the 'Potentials of Cooperation with African Initiated Churches for Sustainable 


\section{Ignatius Swart}

Development'. As such, the chapter wants to acknowledge that the spectrum of churches included in contributions to the development-from-below thesis has been well accommodated by the operational definition of AICs advanced by the programme and project. In this definition, for which the Berlin-based researchers find important direct support in the work of African scholars such as John Pobee and Gabriel Ositelu, AICs 'denote all churches founded by Africans, in Africa and without direct links to "Missionary godfathers"' (Öhlmann, Frost, and Gräb 2016, 2). By implication, this definition therefore makes it possible and justifiable for the Berlin group to include the familiar African Independenttype Churches (Zionist, Apostolic, and Ethiopian) and what have become known as the new African-founded Pentecostal-Charismatic Churches (PCCs) in an integrated research focus (Öhlmann et al. 2016; Öhlmann, Frost, and Gräb 2017). Moreover, while they acknowledge that this aggregation cannot ignore 'the substantial heterogeneity' of the churches involved, they nevertheless argue that a number of common features can be identified to justify such incorporation. This includes the fact that both these groups 'fall into the definition of African initiated' that, unlike many mainline or missionary churches, can 'with very few exceptions' not yet be considered 'partners of international development agencies' (Öhlmann et al. 2016, 2). But perhaps most importantly, it also includes the way in which both groups adopt a similar spiritual worldview dominated by a belief in the Holy Spirit, spiritual forces and the importance of healing (ibid.).

As already suggested, this chapter finds particular support for its own explorative framework through the way in which both the familiar African Independenttype Churches and the new African-founded PCCs are presented in the literature as exponents of the dynamics of development from below. Thus, whereas discussions of the development-from-below thesis may in certain cases still offer separate perspectives on these two groups of churches as exponents of development from below, the more important point is that both groups are not only valued in terms of this thesis, but that this valuation is often done in a way that resonates with the 'blurred typological distinction' (Meyer 2004, 452; see also Schlemmer 2008, 25-26) between the two groups. From this vantage point, this chapter now identifies and discusses five dimensions that can be said to define the theoretical claim of the dynamics of development from below in the literature on AICs and development. The chapter then concludes with a critical evaluation of the thesis by considering the promises, but importantly also the challenges and limitations, the thesis may hold for an ongoing research focus on AICs and development. This more specifically entails that the chapter finds undoubted promise in deepening a research exploration of AICs and development along the lines of the development-from-below thesis identified in this chapter. Yet, it at the same time also entails that the chapter finds it necessary to qualify this promise by identifying with the synergistic approach in the development studies literature, which highlights the fundamental importance of a synergistic relationship between bottom-up and top-down processes of development to achieve broad-based development. 


\section{Dimensions of the development-from-below thesis}

This chapter's identification of distinctive dimensions of the development-frombelow thesis in the literature on AICs and development does not imply that other readings of the selected material may not lead to additional or different identifications and formulations related to this thesis. Accordingly, it is also not suggested that the selected corpus of material on which the present identification is based (see the overview presented in Table 4.1) cannot be expanded by additional discoveries of relevant material. From this vantage point, this chapter depends on a corpus of literature that its author has within the constraints of available time and resources been able to identify and study. This necessarily leads to the acknowledgement that the chapter, for the purpose of its analytic undertaking, relies on a corpus of material that is strongly dominated by contributions from the South African context. While it can therefore rightly be argued that there is an important need to strengthen the wider African focus in this chapter in an anticipated further exploration of the topical focus, this identification is not seen to devalue the meaningfulness of the present undertaking to begin to learn how a particular thesis is seemingly giving ongoing shape to academic debates about the group of churches focused upon in this chapter.

Against this backdrop, in the following discussion five distinctive clusters of ideas and perspectives are presented that can be considered as comprehensive in terms of their capturing of essential dimensions across the respective literature. By way of orientation, readers are again referred to Table 4.1 and the summary it presents of the following three indicators across the respective literature: (1) paraphrasing of the development-from-below idea; (2) the AICs involved in the development of this idea (African Independent Churches and/or PCCs); and (3) the research location and type of research undertaken.

\section{Development from below as a desecularised catchphrase or idea}

In view of a closer encounter with the development-from-below thesis in the literature on AICs and development, it becomes important to note from the outset that development from below constitutes a catchphrase or idea that is not original to the debate on religion and development. As a distinctive catchphrase or idea, development from below has its origins in international development studies discourse dating back as far as the late 1960s when, because of a growing disillusionment with the dominant modernisation model of development and its accompanying 'top-down' or 'trickle down' approach to economic development, the need arose for the conceptualisation of an alternative development model (Sanyal 1998; Stöhr 1980). Accordingly, it is within this framework that the idea of development from below emerged as a counterpoint to what was otherwise labelled as development from above (Stöhr 1980, 1-3).

In his particularly useful outline of the historical evolution of development from below as an idea complex, Bishwapriya Sanyal points out how the idea drew intellectual strength from both neoclassical economic and neo-Marxist 
Table 4.1 Overview of literature capturing the development-from-below thesis

\begin{tabular}{|c|c|c|c|}
\hline Selected literature 1 & $\begin{array}{l}\text { Paraphrase of the development-from- } \\
\text { below idea }\end{array}$ & AICs involved & $\begin{array}{l}\text { Research location and type of } \\
\text { research }\end{array}$ \\
\hline $\begin{array}{l}\text { Robert C. Garner. 2000. 'Religion as Source of } \\
\text { Social Change in the New South Africa'. (journal } \\
\text { article) }\end{array}$ & social change from below & $\begin{array}{l}\text { African Independent } \\
\text { Churches and PCCs }\end{array}$ & $\begin{array}{l}\text { Empirical research in Edenvale } \\
\text { township, KwaZulu-Natal, } \\
\text { South Africa }\end{array}$ \\
\hline $\begin{array}{l}\text { Lawrence Schlemmer. 2008. Dormant Capital: } \\
\text { Pentecostalism in South Africa and its Potential Social } \\
\text { and Economic Role. (research report) }\end{array}$ & development from below & $\begin{array}{l}\text { African Independent } \\
\text { Churches and PCCs }\end{array}$ & $\begin{array}{l}\text { Empirical research in various } \\
\text { locations in South Africa \& } \\
\text { literature research }\end{array}$ \\
\hline $\begin{array}{l}\text { Barbara Bompani. 2008. 'African Independent } \\
\text { Churches in Post-Apartheid South Africa: New } \\
\text { Political Interpretations'. (journal article) }\end{array}$ & politics from below & $\begin{array}{l}\text { African Independent } \\
\text { Churches }\end{array}$ & $\begin{array}{l}\text { Empirical research in Jabulani, } \\
\text { north-west Soweto, South } \\
\text { Africa }\end{array}$ \\
\hline $\begin{array}{l}\text { Barbara Bompani. 2010. 'Religion and } \\
\text { Development from Below: Independent } \\
\text { Christianity in South Africa'. (journal article) }\end{array}$ & development from below & $\begin{array}{l}\text { African Independent } \\
\text { Churches }\end{array}$ & $\begin{array}{l}\text { Empirical research in Jabulani, } \\
\text { north-west Soweto, South } \\
\text { Africa }\end{array}$ \\
\hline $\begin{array}{l}\text { Barbara Bompani and Maria Frahm-Arp, eds. } \\
\text { 2010. Development and Politics from Below: } \\
\text { Exploring Religious Spaces in the African State. } \\
\text { (anthology) }\end{array}$ & development and politics from below & $\begin{array}{l}\text { African Independent } \\
\text { Churches and PCCs }\end{array}$ & $\begin{array}{l}\text { Empirical and theoretical } \\
\text { research related to different } \\
\text { countries in sub-Saharan } \\
\text { Africa }\end{array}$ \\
\hline $\begin{array}{l}\text { Ann Bernstein and Stephen Rule. 2010. 'Flying } \\
\text { under South Africa's Radar: The Growth and }\end{array}$ & $\begin{array}{l}\text { PCCs depicted as 'bottom-up } \\
\text { phenomena' that can become drivers }\end{array}$ & PCCs & $\begin{array}{l}\text { Empirical research in various } \\
\text { locations in South Africa }\end{array}$ \\
\hline
\end{tabular}


Barbara Bompani. 2015. 'Religion and

Development in Sub-Saharan Africa: An

Overview'. (book chapter)

Dena Freeman. 2015. 'Pentecostalism and

Economic Development in Sub-Saharan Africa'. (book chapter)

Afe Adogame. 2016. 'African Christianities and the Politics of Development from Below'. (journal article)

Philipp Öhlmann, Marie-Luise Frost, and Wilhelm AICs' rootedness in communities Gräb. 2016. 'African Initiated Churches' Potential makes them actual and potential as Development Actors'. (journal article)

Philipp Öhlmann, Marie-Luise Frost, and Wilhelm Gräb. 2017. 'African Initiated Churches' and sustainable development in South Africa potentials and perspectives'. (discussion paper) development actors

African Independent Churches depicted as representatives of a 'development ethos' that promotes local community initiatives

PCCs depicted as catalysts of a 'transformation of behaviour' that can lead to upward socioeconomic mobility

politics of development from below, development from below

AICs' activities depicted as starting at the micro and meso levels of society holding potential for ecological sustainability in the long run
African Independent Empirically informed

Churches and PCCs theoretical research relevant to the sub-Saharan African region

PCCs Empirically informed

theoretical research relevant to the sub-Saharan African region

PCCs

Theoretical research and ethnographic research of RCCG in Nigeria

African Independent Empirical research in the Churches and PCCs Gauteng and Limpopo provinces of South Africa

African Independent Empirical research in the Churches and PCCs northern provinces of South Africa

Note

1 See the reference list at the end of this chapter for the full bibliographical details of the selected literature in this table. 
critiques of the mainstream development paradigm in the period under discussion. Albeit from widely opposite ideological positions, the two intellectual streams were unified in their similar critical biases against 'all dominant institutions at the top' and particularly targeted the state as the root cause of the failures of development (Sanyal 1998, 4, 5). In turn, through the intellectual climate created by the different strands of critique, development from below consequently emerged as the label for a 'new, conceptually eclectic approach' (ibid., 5) that resonated with both strands. In the case of neoclassical economic argumentation, proponents of this approach could especially relate, in opposition to conventional state policies, to arguments that wanted to give precedence to the efficiency of small farmers and micro-businesses over big farmers and large businesses in promoting grass-roots economic development (ibid.). Conversely, in the case of neo-Marxist argumentation, proponents of the approach felt equally attracted to arguments that the economic and political interests of the poor would be better served by projects and policies steered towards 'autonomous development effort at the bottom', disconnected from the exploitative tendencies of 'institutions at the top' (ibid., 5-6). Taken together, this all boiled down to the conviction that aspirations for development were best served by 'efforts at the bottom by people themselves for generating income and employment and for political mobilization' (ibid., 6; cf. Stöhr 1980, 8).

Following from the very concise historical perspective provided so far, it becomes important to note how a longer history of the conceptual and theoretical evolution of the idea of development from below has given direction to various theoretical strands of a so-called alternative development paradigm that were promoted in international debates about development in the 1980s and 1990s. Significantly, this included theoretical developments labelled 'people-centred development', 'popular development', 'people's self-development', 'autonomous development', and 'participatory development' (see e.g. Brohman 1996; Carmen 1996; Korten 1990; Rahman 1993). But equally significant from an agency perspective, it also included substantial intellectual investment in the development of a cross-cutting debate about non-governmental organisations (NGOs) as preferred catalysts of the ideal of development from below and its various conceptual expressions (see e.g. Brohman 1996, 253-7; Korten 1990). In the words of Sanyal (1998, 2), with regard to this preference for the agency role of NGOs (in the wake of a strong anti-state sentiment in relation to development agency):

There were many arguments in support of NGOs ... I want to point out the crucial assumption underlying these arguments: that NGOs are particularly appropriate agents for fostering development from below because their organizational priorities and procedures are diametrically opposite to those of the institutions at the top. Unlike state and market institutions, which are driven by the need for social control and profit, NGOs are interested primarily in building communities ... NGOs, unlike the state, neither rely upon coercive forces nor adopt profit-seeking mechanisms, as is customary for market institutions. Rather, NGOs rely solely on solidarity bondings in 
civil society; and this solidarity is nurtured through decentralized and participatory decision making supported by voluntary local efforts.

This observation about NGOs as preferred agents of the dynamics of development from below subsequently brings us to an essential point in the discussion. Whereas authors from the selected literature on AICs and development find little need to relate their own argumentation to the one about NGOs, the implication is nevertheless that in the debate about AICs and development, these churches have replaced secular NGOs as the preferred agents of the dynamics of development from below. Moreover, when considered in terms of NGO organisational theory, AICs could according to this appreciation as developmentfrom-below agents even be seen as surpassing NGOs' role as 'third-party' organisations that operate on behalf of people's interests (see the quote from Sanyal's discussion above). Instead, they could be seen as taking on the role of 'first-party' organisations that embody people's direct participation in events (Korten 1990, 100-102).

Consequently, in the selected literature an image of AICs as people's organisations strongly emerges from the way in which they are depicted as flourishing institutions on the ground. In contrast to the inability of other institutional formations (not least the state's) to do so, they are depicted in people's organisational mode as successful in the way in which they become fundamental in accommodating poor (but also middle-class) people's 'everyday lived experiences' (Adogame 2016, 2) that incorporate both the spiritual and worldly dimensions as an integrated whole (Adogame 2016, 1-3; Bompani 2010, 309; Bompani and Frahm-Arp 2010b, 2). For an author such as Barbara Bompani, who focused her empirical research on African Independent Churches in South Africa, it is AICs' 'life-enhancing activities' (Bompani 2010, 309) that make them so attractive to their followers. African Independent Churches, she argues, become 'communities in which people can rely on strong ties within the religious network and fully participate in both spiritual and earthly activities' (ibid., italics added). And it is from this vantage point, she further argues, that these churches have shown a proven ability to respond to both the spiritual and tangible 'insecurities' of their followers. Whereas the former insecurities pertain to their need for protection against evil forces (which are perceived as real in African cosmology), the latter very specifically involve the socioeconomic dimensions of their lives and their own active participation in them:

Especially in the post-apartheid context, AICs offer concrete resources (alongside their religious inputs) that attract new believers. AICs are involved in important economic activities such as savings clubs, lending societies ... and burial societies that encompass millions of South African rand. These communities play a strong and supportive role among black Africans in a deprived economic situation in which there are few other development agencies or organisations operating on a wider scale.

(Bompani 2010, 310; cf. Bompani 2015, 106) 
It follows that for some authors (noticeably from the Berlin group) it has therefore become important to allude to the holistic view that guides AIC members' understanding of development, not least among their leadership. According to this view, there is an insistence among AIC leadership that the spiritual dimension of people's lives belongs inseparably to a wider, comprehensive understanding of development that also constitutes social and material dimensions. For AIC leaders, it is therefore the task of their churches to support their members in all these areas, in order to 'change' or develop 'the whole person' (Freeman 2015, 117; Öhlmann et al. 2016, 5, 10, 2017, 4, 9).

Based on such insistence on understanding development in a comprehensive or holistic way, it becomes possible to state that the spiritual aspect takes precedence in the way that authors emphasise this aspect. To this extent the spiritual or religious aspect is not only upheld as the determining factor that shapes AIC members' view of the world and by implication their understanding of development (Adogame 2016, 1-3, 7-10; Bompani 2015, 110; Bompani and FrahmArp 2010b, 3; Öhlmann et al. 2016, 9, 2017, 9), but is also credited as the determining factor, through the 'transformations of subjectivity' (Freeman 2015, 117), that brings about AIC members' (noticeably from the PCCs) tangible social and economic upward mobility (Bernstein and Rule 2010, 104-105, 122-127; Freeman 2015, 119-123; Garner 2000, 315, 324, 329, 337; Schlemmer 2008, 78-79, 80-83, 86-87).

It does not come as a surprise, therefore, that a strong challenge to the metanarratives of mainstream (western) development theory and its underlying thesis of secularisation emerges in the selected literature. While more pronounced in some contributions but nevertheless also implied in others, the call is for rethinking the nexus between religion and modernity based on the accumulating research evidence about AICs in the development sphere. Based on the new evidence from below, most often in contexts where the state has not met the desired expectations as a development actor, the thesis advanced is of AICs and religion as constructive agents of a kind of modernity in which religion and religious faith are not antithetical to development and progress (Bompani 2010, 2015; Bompani and Frahm-Arp 2010b, 2010c). Moreover, this could be understood as a kind of modernity that is not antithetical to the ideals of modern democratic capitalism (Bernstein and Rule 2010; Freeman 2015; Garner 2000; Schlemmer 2008), but operates within an alternative meta-theoretical framework that allows for the possibility of multiple or plural conceptions of modernity (Bompani and Frahm-Arp 2010c, 247-249).

\section{Development from below as a counterpoint to development from above and concomitant state failure}

This chapter has already alluded to the way in which development from below and development from above are projected as two major contrasting images or ideas in the selected literature on AICs and development. Thus, not unlike its counterparts in the literature on an alternative development paradigm 
highlighted earlier, in the selected literature a rather extensive range of actors and forces can be identified that are associated with the dynamics of development from above. More pointedly, this includes reference to the World Bank, International Monetary Fund (IMF), United Nations Development Programme, the apparatus of western-led development, the European Enlightenment, structural adjustment programmes, colonialism (Adogame 2016, 1-3; Bompani 2015, 101, 103) and even the Human Development Index (HDI), NGOs and development scholars of a particular kind (Adogame 2016, 2-4), as well as macroscale economic development approaches (Freeman 2015, 114).

Yet while these actors and forces can all in one way or another be related to the failures in bringing about authentic development for poor people and communities on the ground (cf. Garner 2000, 315; Schlemmer 2008, 9), one of the outstanding theoretical claims in the selected literature is that the state - or for some more specifically 'the post-colonial "developmental” state' (Garner 2000, 315) - stands at the helm of those development failures. As such, what emerges from this theoretical claim is a particularly negative view of the African state plagued as it is by wide-scale corruption, an inability to deliver services, or to create employment and combat crime (Bompani 2010, 313, 2015, 103; Bompani and Frahm-Arp 2010b, 6-7; Schlemmer 2008, 83) - as by and large incapable of meeting the legitimate development aspirations of its citizens on the ground.

A pessimistic view consequently prevails in the selected literature about the prospects of the state being able to transform itself into a more reliable and viable agent of grass-roots development (Garner 2000, 315; Schlemmer 2008, 9; Bernstein and Rule 2010, 126; Bompani 2010, 313, 2015; Adogame 2016, 7). The inclination is therefore to go beyond hope that the state will deliver and, based on empirical evidence, commend the way in which AICs acting in people-oriented organisational mode generate self-help and self-development initiatives (Bompani 2010, 321; Schlemmer 2008, 7, 83-85; also Adogame 2016, 7; Bompani 2015, 103). This promotes an image of AICs' ability 'to reach where the state cannot' (Bernstein and Rule 2010, 126; cf. Bompani 2015, 104; Öhlmann et al. 2016, 7; Schlemmer 2008, 83-85) by promoting a new sense of agency, ownership, and self-esteem among its members (Bernstein and Rule 2010, 104-105, 126; Bompani 2010, 314-315; Freeman 2015, 117-119).

It is also in relation to this dimension of the development-from-below thesis that a perspective on AICs as being at the centre of a dynamics of slow but independent and steady upward mobility again emerges. For authors from the selected literature, writing in the wake of evident state inability and outright state failure, this dynamic is manifested through numerous examples of smallscale, grass-roots activities that involve different target groups (such as youths and women) and span across the different spheres of social, economic and spiritual life. In terms of an even more concrete identification, it includes activities and initiatives directed at meeting immediate survival and welfare needs, pastoral counselling, HIV and AIDS care, rehabilitation from substance abuse, health services, youth empowerment and recreation, primary, secondary, and tertiary education, entrepreneurship, financial empowerment and skills development, 


\section{Ignatius Swart}

and social housing (Adogame 2016, 7-11; Bernstein and Rule 2010, 102-104, 106, 123-126; Bompani 2010, 309-310, 314-320; 2015, 103; Freeman 2015, 120; Öhlmann et al. 2016, 6-8, 2017, 7).

Finally, a provocative but worthwhile interpretation from the selected literature on AICs' central position in the move away from state dependence to selfreliance is thus that 'religion' could be perceived as surpassing 'politics in the search for the better life' (Schlemmer 2008, 83). For Lawrence Schlemmer, this perception at least seemed real for those persons who were interviewed both in the townships and in the suburbs of South Africa, suggesting 'that religion had achieved far more in improving lives and morale than have the political programmes and promises' they (i.e. the interviewees) encountered (ibid.). Effectively, this finding therefore testifies to a group of people for whom the state and the political dynamics associated with it play a very insignificant role in the way that they strive to live their lives meaningfully:

In the survey results we were surprised at how little impact political disillusionment seemed to have on personal morale among believers as opposed to non-churchgoers.... Religious commitment in general imparts a buoyant mood and spiritual 'capital' seems to be correlated with social capital, confidence, patience and fortitude. Religion seems to insulate people from political and economic stress even without 'other worldly' seclusion or fatalism... [A]ll categories of churchgoers reflected sentiments of selfreliance - a critical finding in view of the mass dependence on state support in the population at large.

(ibid., 84) $)^{1}$

\section{Development from below as a political dynamic}

For at least some proponents of the development-from-below thesis, the reality of religion's superior contribution to the well-being of AIC members does not, however, imply an apolitical stance in AIC conscience and engagement. Thus, in contrast to an interpretation that goes so far as to associate AICs and their members with such a stance or at most with a limited 'influence in public affairs' (Bernstein and Rule 2010, 116), an argument advanced is that a political dimension is indissolubly part of the dynamics of development from below associated with AICs. As a result, what comes to the fore is a clear conceptual overlap suggested by the use of phrases such as 'politics of development from below' (Adogame 2016) and 'politics and development from below' (Bompani and Frahm-Arp 2010a, 2010b), as well as applications of the catchphrases 'development from below' (Bompani 2010) and 'politics from below' (Bompani 2008) to the same empirical research.

In terms of a more specific claim to the political, then, one could start with Adogame and Bompani's rather similar rendering of political meaning according to the way AICs exert themselves as deliverers of social services to their members. With reference to the example of the Redeemed Christian Church of 
God (RCCG) in Nigeria, for Adogame $(2016,7)$ the RCCG's increasing acceptance of 'extra-religious functions such as social welfare programmes' could be taken as an example of a church that engages itself in the 'public sphere' and makes a contribution where other constituencies ${ }^{3}$ are noticeably failing. And for Bompani (2010, 321), based on her research in the suburb of Jabulani in Soweto, South Africa, the engagement of AICs of the African Independent type in the social sphere could likewise be interpreted as 'political in the way they concern themselves pragmatically with local community issues like housing unemployment, health care, and education'. In the context of Bompani's overall argumentation, these are issues that not only expose the neglect and failure of the post-apartheid state, but at the same time highlight the significance of AICs as local actors challenging this neglect and failure through their active concern with the social well-being of their members (ibid., 312-322).

It should be conceded at this point that one effectively remains confined to the contributions of Bompani for a further elaboration of the political perspective in the selected literature. While she largely has to depend on her already mentioned ethnographic research in South Africa to advance her argument, the way in which she uses her empirical findings to challenge conventional apolitical interpretations of the AICs is nevertheless significant. For Bompani, it becomes essential to adopt 'an alternative approach' to 'religion and politics' (Bompani 2008, 674). When considering the case of the AICs in the post-apartheid context in particular, she contends that such an approach should lead one to challenge a number of traditional assumptions: that the political effectiveness of AIC leaders should be measured in the light of their public outspokenness at the national level (ibid., 671); that any visible political inclination among AICs should be related to 'institutionalised components of politics like party organisations' (ibid., 677); and that silence should necessarily be equated with withdrawal from politics (ibid., 669).

It follows that for Bompani, also when reflecting with her fellow author Maria Frahm-Arp on an African reality that goes beyond the South African context, it becomes fundamental to gain a deeper insight into what happens on the local level in order to properly appreciate AICs' political significance (ibid., 666, 671; Bompani 2010, 310, 314, 321; Bompani and Frahm-Arp 2010b, 3; 2010c, 244-246, 248). Based on her own empirical findings, but also on the wider accounts of empirical and theoretical insights that she draws upon with Frahm-Arp, different layers of interpretation emerge.

The first is an interpretation that far from typecasting AICs as depoliticised entities, appreciates them as reservoirs of 'cultural autonomy' and 'moral authority' within a larger and often turbulent societal dynamics (Bompani and FrahmArp 2010c, 245). Accordingly, the implication here is that AICs' apparent withdrawal from formal politics as well as their independent stance vis-à-vis the state, government and mainstream development agencies could be interpreted as a political act in itself. Through such distancing they not only guard their members from the divisive and corruptive influences of political organisations (Bompani 2008, 666-670; Bompani and Frahm-Arp 2010b, 7; 2010c, 246), but 


\section{Ignatius Swart}

shielded from such influences also function as independent spaces, where 'the potentiality of self-development, freedom and self-empowerment' are developed (Bompani 2010, 321; Bompani and Frahm-Arp 2010c, 245; cf. Bompani 2015, 105-106).

From the vantage point of such a position of independence a second layer of interpretation also gives evidence of a more overt critical political conscience and engagement on the ground. Beyond the surface of apparent withdrawal, the picture gained particularly from Bompani's South African research is one where religion and politics meet far more purposefully in the lives of AIC members. In the post-apartheid context of Jabulani in Soweto, she contends, politics remains 'a fundamental component of social interaction and discourse', a reality from which the churches in this township can also not escape, given their members' own experiences of 'the rigours of apartheid' (Bompani 2008, 670).

Key to Bompani's argument, then, is that AICs in Jabulani constitute an indissoluble part of the aforementioned political dynamics. By drawing on her own participatory observation, for her one of the most significant starting points was to visit the different liturgical events of these churches. Since it was at these events that a political conscience was clearly cultivated among church members as part of the religious discourse and performance. In the words of Bompani that recall one case in point of her common experience across events she attended:

In attending churches in Soweto, I perceived that politics emerged spontaneously from everyday religious settings, observances and discourses. Being at the liturgy on Sunday at Jabulani meant also debating the nationbuilding process and discussing corruption, unemployment and government.... On Sunday 9 December 2001, the reading inspired Bishop Ntongana to talk of social justice and urged his listeners to fight for their rights. Referring to the stagnant conditions of poverty in the township ... Ntongana addressed the audience thus: 'Fight for your rights, fight for justice, because there cannot be peace without justice and no reconciliation without peace. How can we forgive for the past if we keep suffering now? Things have to change.'

(ibid., 674-675)

It can be concluded here that the reality presented by Bompani is therefore far from a non-political one. Instead, it is a reality where 'political activism and public roles' (ibid., 671) were enacted from a position of political independence visible at the local level through the way in which AIC leaders, but also other church members, took the lead in instilling and cultivating a critical awareness among their members. Almost a decade after apartheid (i.e. at the time of Bompani's research), such outspokenness was directed at issues of state neglect, such as lack of service delivery, but also at the need for AIC members to claim their rights as citizens in the new democratic dispensation (ibid., 671-677; cf. Bompani 2010, 312-314). This activism, however, significantly extended beyond AIC liturgical events to more overt public action, as for instance 
illustrated by two examples: a march against crime that was organised by local Independent Churches and a report that was drafted by a regional meeting of the Council of African Instituted Churches (CAIC) held in October 2001 in Jabulani for submission to the local authorities. The latter document, Bompani significantly summarises, 'emphasised the unacceptable level of poverty in the communities, citing social injustice and inequitable wealth distribution ... as the major causes' (ibid., 671-672).

\section{Development from below as social change from below invigorated by radical personal transformation and a remaking of the Protestant ethic}

This chapter, in its discussion of a first dimension of the development-frombelow thesis, has already alluded to authors' appreciation of the role of spiritual life and related personal transformation as a most important causal factor in the dynamics of development from below. In terms of what could otherwise be defined as AIC members' devotion to a life of exceptional faith commitment, this element is given further substance and direction in the selected literature to the extent that it could rightfully take its place as a distinguishable fourth dimension of the development-from-below thesis. In particular, this pertains to the way in which a number of authors portray the distinguishable features of personal transformation and high faith commitment - specifically with regard to AICs of the Pentecostal variant - as not only conducive to but in fact also manifesting a remaking of the Protestant ethic famously theorised by sociologist Max Weber (Bernstein and Rule 2010, 95-96; Freeman 2015, 123; Garner 2000, 311, 329; Schlemmer 2008, 22, 86, 81).

This claim of a 'remaking' of the Protestant ethic is directly linked to an appreciation of contemporary Pentecostalism as being at the centre of 'a new wave of Protestantism' (Bernstein and Rule 2010, 95), which in turn also holds new significance for the Weberian thesis. This implies that Protestant Churches of mainline descent have largely lost their social and ethical influence in contemporary society. In contrast to this decline, however, Pentecostal Churches are held in high esteem for their popular appeal and many features that fit Weber's description of the Protestant ethic (Bernstein and Rule 2010, 95-96; Garner 2000, 312-316, 329, 335-337; Schlemmer 2008, 22, 24-25). This is seen by the authors from the selected literature as a development that is as pertinent to the religious landscape of African societies as it is to other parts of the world.

While the aforementioned strongly features as a perspective on African PCCs and development from within the South African context in the selected literature (Bernstein and Rule 2010; Garner 2000; Schlemmer 2008), this perspective is also given a broader framework through Dena Freeman's (2015) important contribution 'Pentecostalism and economic development in subSaharan Africa'. In this part of the world, Freeman $(2015,115)$ asserts, there has been nothing less than a 'Pentecostal explosion' whereby 'millions of people 
... have joined Pentecostal churches'. But beyond such numerical significance, for Freeman, in the context of an argumentation about development, of special significance has been Pentecostalism's ability to resonate with the African worldview more than other forms of Christianity have been able to do.

Pentecostalism shares the basic ontology of good and bad spirits, and embraces supernatural beings (God, Jesus, demons) that can have a direct influence in the world.... In this way Pentecostalism becomes a lot more meaningful and powerful to Africans than earlier forms of Christianity. And in this power we find an astonishing ability to bring about change and transformation - often in the direction of what we usually call 'development'.

(ibid., 116-117)

Having introduced the topic of development in this way, Freeman makes the crucial point that the strength of African PCCs' contribution does not lie in the number of development projects they have been initiated. PCCs in Africa, she observes, have rather been slow 'in setting up "development wings" and joining in with explicitly development-focused activities' (ibid., 116). In contrast to this lack, however, a key point of her argument is that African PCCs' greatest contribution to development is made through what has already been captured in this chapter as the ability to bring about transformations of subjectivity - a remaking of the individual, the whole person. As she elaborates:

By far the greatest impact that Pentecostals have on development in Africa comes ... from the changes instilled in 'believers' by the religious activities of the churches themselves. In these churches 'religion' is not separated from 'development'. Church leaders take a holistic focus on the 'whole person' and try to bring about change socially and economically, as well as spiritually.

(ibid, 116-117)

For Freeman, as for the other authors referenced above, what is at stake in African Pentecostal faith is nothing less than a radical personal transformation of its followers. Of special importance, this is a kind of transformation whereby such individuals experience a new sense of freedom from past captivities (evil spirits, costly traditional practices, mental attitudes of hopelessness, and despair) that in turn leads to a new sense of empowerment, self-worth, confidence, optimism, and agency to grasp opportunities when they come about. What is implicated is not only a radical change in mental attitude, but also a kind of behaviour that is characterised by moral discipline and a particular value orientation. This includes a new devotion on the part of believers to a frugal, disciplined lifestyle characterised by hard work, educational improvement, changed consumption patterns, and abstinence from alcohol, tobacco, and extramarital relationships (Bernstein and Rule 2010, 98-106, 111-117, 122-127; Freeman 2015, 117-119, 121-123; Garner 2000, 325-9; Schlemmer 2008, 45-52, 59-64, 70-72, 75-87). 
Consequently, it is not difficult to grasp why for this specific group of authors contemporary African Pentecostalism displays features that relate favourably to the Weberian thesis. For them, contemporary African Pentecostalism and its associated ecclesial formations fall nothing short of being a new vibrant movement that holds huge potential for large-scale social and economic development from below (Bernstein and Rule 2010, 122-127; Garner 2000, 337; Schlemmer 2008; cf. Freeman 2015, 115-116, 123). Hence, it is a movement driven by the same kind of 'this-worldly asceticism' (Bernstein and Rule 2010, 105; Schlemmer 2008, 61, 81, 86) that Weber identified and, through the aforementioned attributes, is put into service of the desire for material and economic improvement. By implication, it is an orientation founded on the belief that salvation 'can take place in this life' (Freeman 2015, 120), which in turn explains the visible entrepreneurial drive in many PCCs stimulating business behaviour among their members and encouraging them to start businesses (Bernstein and Rule 2010, 98, 102-103, 106, 108-111, 125-126; Freeman 2015, 120; Schlemmer 2008, 33, 76, 78).

In concluding this brief account of how a claim to personal transformation and a closely related remaking of the Protestant ethic stands central to the identification of a fourth dimension of the development-from-below thesis, it seems worthwhile to quote Freeman again, this time her own concluding appreciation of Pentecostalism's contribution to such a dynamic and by implication development from below in African society. Provocative in the way in which a favourable connection is drawn between the Pentecostal contribution and the demands of neoliberal capitalism, Freeman concludes:

In The Protestant Ethic and the Spirit of Capitalism, Weber ... argued that there was an elective affinity between the spread of Protestant Christianity and the growth of capitalism in sixteenth- and seventeenth-century Europe.... While there are many differences between sixteenth-century Calvinism and twenty-first-century Pentecostalism ... there are nonetheless also many parallels, and I have sought to show here how Pentecostalism plays a similar role in Africa today. It is a form of Protestantism that stimulates a transformation of behaviour that can lead to success, or at least upward mobility, in the contemporary neoliberal economy. It motivates new behaviours and renders them moral. It promotes hard work, saving and limitation on certain types of unproductive consumption. Thus it leads people to participate, and succeed, in the capitalist economy. This, at least in present thinking, is what we generally mean by development.

$(2015,123)$

\section{Development from below as an acknowledged capacity to generate social capital}

In the selected literature, not surprisingly one could say, several authors also draw strongly on the notion of social capital to describe AICs' strength as 
actors in the dynamics of development from below. This provides the grounds for the identification of a fifth and last dimension of the development-frombelow thesis, an identification that could begin with Bompani's $(2010,322)$ statement at the end of one of her writings claiming that AICs have an acknowledged capacity to generate social capital and thus to mobilise their adherents' (italics added). By implication, therefore, for Bompani this capacity or ability of AICs is not merely something that was revealed by her own research in Jabulani, Soweto, but it represents a more general or broader acknowledgement of AICs' essential nature and ability that becomes evident in a number of ways:

through the great attention given to trust and community relations; through the important role played by the leadership; through local roots and sources of accountability; through a commitment to values compatible with democratisation, good governance, and other forms of sustainability, as well as participation.

(ibid.)

Clearly, then, Bompani's claim to an acknowledged capacity of AICs to generate social capital also reverberates in several other contributions to the development-from-below thesis forming part of the selected literature in this chapter (Adogame 2016, 4; Bernstein and Rule, 2010, 105, 116, 122; Bompani, 2008, 666; 2015, 106; Öhlmann et al. 2016, 4, 9; Schlemmer 2008, 45, 49, 53-54, 84, 89). The contribution by Adogame, for instance, catches one's attention for the way in which he draws upon the well-known conceptual distinction between 'bonding', 'bridging', and 'linking' social capital. Based on his ethnographic research on the RCCG, Adogame advances the argument that the RCCG generates social capital through its local (Nigerian) and international institutional formations. He explains how this formation of social capital starts in the spaces of worship, where numerous forms of socialisation and relationship building take place, but also how it manifests through many initiatives for the social and economic betterment of church members and other people (noticeably also in diaspora contexts) (Adogame 2016, 7). ${ }^{4}$

Thus, one could derive from Adogame's distinctive social capital claim - but also from similar assertive claims by the other authors referenced above - that it is AICs' ability or capacity to generate social capital that ought to be appreciated as the foremost means that enables them to present themselves as a force for advancing development from below. These churches, it is postulated, 'are networks of mutual support undergirded by strong bonding forces and high degrees of trust' (italics added) (Öhlmann et al. 2016, 4; cf. Adogame 2016, 11; Bernstein and Rule 2010, 105, 116; Bompani 2008, 666; 2010, 317; 2015, 106). Consequently, it is this cooperative and relational quality that not only explains AICs' involvement in many concrete activities related to the needs of their members (Öhlmann et al. 2016, 6-7) but also determines the specific " "developmental" ethos' of those activities. Bompani $(2015,106)$ explains: 
Their 'developmental' ethos is particularly evident with the promotion of communities' initiatives and the sustainment of their own improvement through local techniques like protection from evil spirits ... the promotion of strong networks for community support and the running of traditional financial schemes of assistance in poor economic situations.

In drawing this section of the discussion to a close, it however becomes necessary and important to also point to a more complicated picture in the overarching claim to AICs' capacity to generate social capital. Thus, whereas a common claim has been depicted above that assumes the inclusion of both variants of AICs focused upon in this chapter, this more complicated picture pertains to the differences that could be highlighted when dealing with more concrete issues and examples in the selected literature. This first concerns the identification of savings clubs and burial societies as prominent manifestations of AICs' social capital capacity in the contributions by Bompani (2010, 310, 316-320; 2015, 106) and the Berlin group of Öhlmann et al. (2016, 4), respectively. Whereas it becomes clear in Bompani's case that these two examples pertain to AICs of the African Independent-type variant, this differs in the case of the Berlin group's identification of saving clubs and burial societies as practices that feature in both groups of churches.

Finally, the second difference this chapter finds important to highlight takes on additional significance for relating to the political dimension of the development-from-below thesis. More specifically, it concerns the way in which the contradiction between apolitical and political interpretations of AICs' social involvement alluded to in that section of the discussion comes to the fore in the claims made about the social capital dimension in the contributions particularly of Bompani $(2008,2010)$ and Bernstein and Rule (2010).

In the case of Bompani, her focus is confined to a group of AICs of the African Independent variant in a local South African context. Her appreciation is here indissolubly linked to her political interpretation discussed earlier and basically projects the idea that it is those AICs' capacity to generate social capital that generates their particular dynamics as political actors on the ground. In this respect, she adopts, in social capital mould, the notion of 'a network of solidarity' to describe how those churches are fighting for the proper social rights of their members, 'such as education, health, knowledge about HIV, economic support, and housing' (Bompani 2010, 114; see also Bompani 2008, 666).

Yet, in comparison to Bompani, Bernstein and Rule's contribution can be contrasted not only for its distinctive focus on AICs of the Pentecostal variant, but also for relating the latter's capacity to generate social capital to what they perceive as Pentecostals' (albeit Pentecostals confined to the South African context) limited influence in the public realm. For these two authors, while this lack of political or public involvement may be seen as a prevailing weakness, they nevertheless celebrate the fact that "Pentecostals have "social capital" on their side' (Bernstein and Rule 2010, 116); that is, social capital of the degree 
and quality that will continue to enhance their profile as a social and moral force despite the lack of direct political involvement (Bernstein and Rule 2010, $116,122,126)$.

\section{African Initiated Churches and the development-from-below thesis: promises, challenges, and limitations}

This chapter began by postulating how development from below has come into vogue as a distinctive theoretical claim or thesis in the research focus on AICs and development in the academic literature. Based on closer scrutiny of this postulation, one is left with the impression that this thesis is already giving important direction to the research focus on AICs and development. To the extent that the thesis could even be regarded as a dominant idea emanating from this focus, in this chapter five dimensions (one could also call them five thematic areas) have been identified that can be said to constitute promising avenues for an ongoing systematised research undertaking on AICs and development, both from a theoretical and an empirical point of view. Taken together, the five dimensions cannot represent a complete research agenda, but rather a comprehensive agenda that touches on areas that are all crucial to religion and development as a distinctive subject field, namely:

- development from below as a desecularised catchphrase or idea;

- development from below as a counterpoint to development from above and concomitant state failure;

- development from below as a political dynamic;

- development from below as social change from below invigorated by radical personal transformation and a remaking of the Protestant ethic;

- development from below as an acknowledged capacity to generate social capital.

The undertaking in this chapter has also proved to be meaningful in the way that it has at least partly validated an operational definition that categorises both the familiar African Independent-type Churches and African Pentecostal Churches (PCCs) under the umbrella term African Initiated Churches. This has been shown in the way in which both groups of churches are related to the development-frombelow thesis - in other words, presented as actors in the dynamics of development from below. Within this ambit, while the five dimensions identified could rightly be regarded as cross-cutting essential dimensions that define the development-frombelow thesis in the selected literature, their identification and exploration in this chapter also highlight the need for further in-depth research. In particular, here the author of this chapter has in mind a research undertaking that would from the vantage point of an even more representative African focus, ${ }^{5}$ deepen its exploration along the thematic lines developed in this chapter. As a direct consequence, this undertaking should necessarily incorporate more nuanced subcategorisations of African Initiated Churches taking greater cognisance of the diversities within 
both the African Independent and Pentecostal (PCC) variants, such as urban and rural churches and churches of different sizes. But of no lesser importance, such undertaking should also open new possibilities for empirical testing and verification, not least of the contrasting perspectives or emphases that have surfaced from the analytic undertaking in this chapter. In so far as these contrasting perspectives or emphases reflected specifically in the discussions of the third, fourth, and fifth dimensions of the development-from-below thesis, this could be considered the way in which:

- Development from below as a political dynamic (third dimension) has been associated with AICs of the African Independent type through the work of Barbara Bompani (in some instances also with her fellow author Maria Frahm-Arp), while with the exception of one contribution (Adogame) a similar association did not reflect in discussions of AICs of the Pentecostal variant (PCCs).

- Development from below as social change from below invigorated by radical personal transformation and a remaking of the Protestant ethic (fourth dimension) has been associated by the relevant authors as a feature of Charismatic Pentecostalism, while a similar association did not reflect in any discussion of AICs of the African Independent type.

- Development from below as an acknowledged capacity to generate social capital (fifth dimension) has been described as functional within the political inclinations of AICs of the African Independent type (Bompani), while PCCs' capacity to generate social capital has been juxtaposed with their apolitical inclinations in at least one contribution from the selected literature.

In its final conclusion, this chapter importantly finds a need to also go beyond its statement on promises and challenges by arguing that there may be important limitations in a research focus on AICs and development that is directed exclusively by the development-from-below thesis. This stance has relevance especially when one becomes willing to take account of and learn from the development studies literature in which scholars also engage more critically with the development-from-below idea, including work dealing more pointedly with the notion of social capital. In a nutshell, in this sphere of theorising the argument advanced is that in as much as problems of development cannot be solved by top-down strategies of development, it is equally unrealistic to think that they can be solved by a bottom-up approach to development (see e.g. Brohman 1996, 270-276, ch. 11; Friedmann 1995, ch. 7; Sanyal 1998; Stöhr 1980; Woolcock 1998; Woolcock and Narayan 2000). To quote Sanyal (1998, $8,11)$ at some length again, as he captures this theoretical position's counterargument for adopting a synergistic approach (cf. Woolcock 1998; Woolcock and Narayan 2000, 235-239) particularly well:

What is the record of NGO-led, bottom-up development efforts? Nearly twenty-five years and thousands of projects later, the economic impact of 


\section{Ignatius Swart}

bottom-up efforts seems rather small and insignificant.... Although the bottom-up approach was distinctly anti-state in orientation, and was based on the premise that as agents of development from below NGOs should avoid working with the state and other dominant institutions at the top, in reality the experience of relatively successful NGOs indicates that they had worked fairly closely with the government and market institutions.... This finding suggests a reconsideration of development strategy from its preoccupation with either 'trickle down' or 'bottom-up' development. It indicates that, just as development does not trickle down from the top, neither does it effervesce from the bottom. Development requires a synergy between institutions at the top and the bottom, a collaborative effort involving the state, market, and civil society. Action in any one domain alone, however well intended, is not adequate for broad-based development.

This chapter finally concludes by upholding the synergistic approach as an important, if not crucial, pointer for ongoing theory building not only in the research focus on AICs and development, but in fact the field of religion and development as a whole. Clearly, without doing so, there is the real danger of succumbing to what Jones and Petersen $(2011,1296-1300)$ have so importantly highlighted as the tendency to become overtly instrumental, narrow and normative by assigning strengths and qualities to religious organisations that are overstated if not misplaced in situations of great developmental complexity. But to this one could also add the dangers of isolation, essentialism, and absolutism, whereby the wider landscape or architecture of development is basically ignored, including other actors whose ideas and practical worlds are similarly shaped by normative frameworks for development.

\section{Notes}

1 The limitation of confinement to a South African perspective for drawing more generic conclusions is recognised here. Nevertheless, favourable comparisons can be drawn between Schlemmer's description of AIC mental outlook in the South African context and descriptions elsewhere in the selected literature, such as by Adogame (2016, 7), of members of the Redeemed Christian Church of God's social and spiritual inclinations in Nigeria, and by Freeman (2015, 117-120) of Pentecostal subjectivity across different African locations.

2 Adogame continues to discuss in greater detail the RCCG's establishment of structures (programmes) to combat HIV and drug use/abuse among young people (2016, 7-10).

3 In a more generalised manner, with reference to the larger African context and African diaspora, Adogame $(2016,7)$ alludes to the deterioration of 'constituencies such as governments, trade unions ... [and] blue-collar workplaces'.

4 Cf. n. 3 above and the corresponding main text in this chapter.

5 Here one may recall this chapter's early acknowledgement about its reliance on a corpus of material strongly dominated by contributions from the South African context and the consequent need to expand the present exploration towards a more representative African focus. 


\section{References}

Adogame, Afe. 2016. 'African Christianities and the Politics of Development from Below.' HTS Theological Studies 72, no. 4: 1-11. http://dx.doi. org/10.4102/hts. v72i4.4065

Bernstein, Ann, and Stephen Rule. 2010. 'Flying under South Africa's Radar: The Growth and Impact of Pentecostals in a Developing Country.' In The Hidden Form of Capital: Spiritual Influences in Societal Progress, edited by Peter L. Berger, and Gordon Redding, 91-131. London: Anthem Press.

Bompani, Barbara. 2008. 'African Independent Churches in Post-Apartheid South Africa: New Political Interpretations.' Journal of Southern African Studies 34 (3): 665-677.

Bompani, Barbara. 2010. 'Religion and Development from Below: Independent Christianity in South Africa.' Journal of Religion in Africa 40, no. 3: 307-330.

Bompani, Barbara. 2015. 'Religion and Development in Sub-Saharan Africa.' In The Routledge Handbook of Religions and Global Development, edited by Emma Tomalin, 101-113, London: Routledge.

Bompani, Barbara, and Maria Frahm-Arp, eds. 2010a. Development and Politics from Below: Exploring Religious Spaces in the African State. Basingstoke: Palgrave Macmillan.

Bompani, Barbara, and Maria Frahm-Arp. 2010b. 'Introduction: Development and Politics from Below: New Conceptual Interpretations.' In Development and Politics from Below: Exploring Religious Spaces in the African State, edited by Barbara Bompani and Maria Frahm-Arp, 1-19, Basingstoke: Palgrave Macmillan.

Bompani, Barbara, and Maria Frahm-Arp. 2010c. 'Conclusion: Reflections on Modernization without Secularization.' In Development and Politics from Below: Exploring Religious Spaces in the African State, edited by Barbara Bompani and Maria Frahm-Arp, 240-251, Basingstoke: Palgrave Macmillan.

Brohman, John. 1996. Popular Development: Rethinking the Theory $\mathcal{B}$ Practice of Development. Oxford: Blackwell.

Carmen, Raff. 1996. Autonomous Development. Humanizing the Landscape: An Excursion into Radical Thinking and Practice. London: Zed Books.

Freeman, Dena. 2015. 'Pentecostalism and Economic Development in Sub-Saharan Africa.' In The Routledge Handbook of Religions and Global Development, edited by Emma Tomalin, 114-126, London: Routledge.

Friedmann, John. 1995. Empowerment: The Politics of Alternative Development. Cambridge, MA: Blackwell.

Garner, Robert C. 2000. 'Religion as a Source of Social Change in the New South Africa.' Journal of Religion in Africa 30, no. 3: 310-343.

Jones, Ben, and Marie Juul Petersen. 2011. 'Instrumental, Narrow, Normative? Reviewing Recent Work on Religion and Development.' Third World Quarterly 32, no. 7: 1291-1306. http://dx.doi.org/10.1080/01436597.2011.596747

Korten, David C. 1990. Getting to the 21st Century: Voluntary Action and the Global Agenda. West Hartford: Kumarian Press.

Meyer, Birgit. 2004. 'Christianity in Africa: From African Independent to PentecostalCharismatic Churches.' Annual Review of Anthropology 33 (2004): 447-474. https:// doi.org/10.1146/annurev.anthro.33.070203.143835

Öhlmann, Philipp, Marie-Luise Frost, and Wilhelm Gräb. 2016. 'African Initiated Churches' Potential as Development Actors.' HTS Theological Studies 72, no. 4: 1-12. http://dx.doi. org/10.4102/hts.v72i4.3825 


\section{Ignatius Swart}

Öhlmann, Philipp, Marie-Luise Frost, and Wilhelm Gräb. 2017. 'African Initiated Churches and Sustainable Development in South Africa - Potentials and Perspectives.' Religion \& Development 01/2017. Discussion Paper Series of the Research Programme on Religious Communities and Sustainable Development. Berlin: Humboldt-Universität zu Berlin.

Rahman, Md. Anisur. 1993. People's Self-Development: Perspectives on Participatory Action Research. London: Zed Books.

Sanyal, Bishwapriya. 1998. 'The Myth of Development from Below.' Paper presented at the Association of Collegiate Schools of Planning, Annual Conference, Pasadena, CA, November 1998.

Schlemmer, Lawrence. 2008. Dormant Capital: Pentecostalism in South Africa and its Potential Social and Economic Role. Johannesburg: Centre for Development and Enterprise.

Stöhr, Walter. 1980. 'Development from Below: The Bottom-Up and Periphery-Inward Development Paradigm.' IIR-Discussion Papers 6. WU Vienna University of Economics and Business, Vienna.

Woolcock, Michael. 1998. 'Social Capital and Economic Development: Towards a Theoretical Synthesis and Policy Framework.' Theory and Society 27 (2): 151-208.

Woolcock, Michael, and Deepa Narayan. 2000. 'Social Capital: Implications for Development Theory, Research, and Policy.' The World Bank Research Observer 15, no. 2: 225-249. 


\section{Distinguished church leader essay \\ Theology in African Initiated \\ Churches - reflections from an East \\ African perspective}

John Njeru Gichimu

\section{Worship}

Unique styles of worship are characteristic for many African Initiated Churches. ${ }^{1}$ Generally, worship is lively, vigorous (enthusiastic), contextual and lengthy. Some worship will begin at 9 a.m. and end late in the evening. Quite a number of Spiritual Churches, e.g. from Western Kenya, hold their worship service on Saturday, but still meet on Sunday for various church activities not limited to a brief worship service, while Nationalist and African Pentecostals hold their worship service on Sunday. ${ }^{2}$ Worship in some AICs begins with repentance and cleansing of the place of worship by casting out demons from the venue for Roho Churches (Roho is the Swahili word for spirit). Nationalist Churches on the other hand use a customised liturgical order of worship adopted from the churches they seceded from. In Spiritual Churches singing precedes every action in a worship service. Songs act as liturgical pause cords and order of service. While the singing is going on, the leaders consult on the next item in the worship service. Consequently, worship songs are sung to prepare the congregation for self-prayers, speaking in tongues (glossolalia), inspiration of the Holy Spirit for prophecy, visions and dreams sharing. In some churches, visions are pronounced to have happened during enthusiastic singing. Dreams and visions interpretations usually form the theme of the sermon. AICs do not pay much attention to sacraments. They do not have a common position on the number of sacraments. The commonest AIC sacraments are baptism, marriage and the Lord's Supper. The Lord's Supper is rarely celebrated in most AICs and if it is, only the founder or successor is qualified to administer it. This expresses a replication of African culture where only the elder holds the powers to bless. The Roho/Spiritual Churches celebrate agape meal in place of Holy Communion. Some Akurinu/Aroti (dreamers) celebrate the communion for seven days though, following the children of Israel commemoration of Passover as stated in Exodus 13:6 'For seven days eat bread made without yeast and on the seventh day hold a festival to the lord' (New International Version). The Nationalist Churches have sacraments similar to the Mission Churches they seceded from. This confirms how the seceding churches carried on with practices experienced from Mission Churches, albeit with local additions to authenticate their belonging to the African context. 
Many AICs have high regards for dress codes. In Nigeria, the Spiritual Churches are called 'white garment churches' because of their emphasis on wearing white gowns. Often the dress codes are established on the basis of biblical scripture. In some Roho Churches turbans are worn in line with Zachariah 3:3-6. Some of the most common symbols African Independent Churches use are white garments, prayer gowns, water, gowns/cassocks and certain colours, e.g. white as symbol of righteousness. Also flags, turbans, sashes, crucifixes, iron rods, wooden rods, incense, candles, rings and many others are common. Taboos among AICs differ from one context to another, but AICs cherish observing marital taboos, menstrual taboos, holiness codes, dietary taboos and other taboos stated in Leviticus. They do not see anything wrong in observing the taboos, as long as the taboos are stated in the Bible.

\section{Spirit and leadership}

The constant advice and presence of the Holy Spirit through dreams, visions and prophecies guides church members in AICs communally while assuring them of God's personal interest in their lives. Evil in the church and in individual lives is confronted, repented of and the evil spirits that lead people to sin are cast out. Jesus is encountered at the point of repentance. Laws of purity establish boundaries between believers and non-believers - those 'of the spirit' and those 'without' the spirit. Frequent repentance ensures a heart cleansed of sin, the dwelling place of the Holy Spirit.

Key to the teaching of these churches is the passage from the prophet Joel 2:28-29, 'And afterwards, I will pour out my spirit on all people. Your sons and daughters will prophesy, your old men will dream dreams, your young men will see visions. Even on my servants, both men and women, I will pour out my Spirit in those days' (New International Version). The Spirit of the Lord will be poured out on all groups of people, women and men, old and young, alike. Hence one of the key themes of Roho Churches has been every member ministry, or in other words, 'what the prophet can do, you can do also'. Exercising the gifts of the Spirit is not restricted to those who are approved by the church hierarchy (cf. the concept of the priesthood of all believers outlined in 1 Peter 2:5). This has created churches that are genuinely popular and owned by the grassroots.

The churches being grassroots movements does not mean though that no leadership is developed in the AICs. Instead, over time the traditional leadership forms of collective leadership as a movement that had roles assigned to everyone changed and formed a new model of leadership that focuses more on individual leaders and removed collective responsibility. The new and the traditional models of leadership need to be mitigated especially when events of succession arise or when the role of women in traditionally patriarchal church structures is challenged by modern forms of leadership. In this leadership situation, the Organization of African Instituted Churches (OAIC) developed a theological training for the leadership of AICs. 


\section{Historical methods of theological training in AICs}

In the African Initiated Churches, the act of worship and faith required of most to be seen and perceived within the local context. Leaders therefore needed to be trained, through learning how to use traditional stories, proverbs and rituals. The first method through which training was done in AICs and even in some up to the present is apprenticeship/mentorship. The variance in the contemporary is the usage of terminologies, e.g. training for ordination, in-service training or in-house training. In this method, the leader of the church automatically becomes the tutor or trainer of the personnel. Although there was no understanding how such a leader got trained, it is obvious that it was through the oral tradition method, which at its best required listening and doing. In this method, knowledge is handed down by word and not by documents or reference books. It also implies that, if one got a chance to serve a church leader in any capacity, that was an opportunity to learn. The other method of training was by occasional meetings-cum-seminars. These were arranged for any person who demonstrated mastery in mass communication and acceptance by the congregation. In this understanding charisma was preferred as a qualification for training. For example, someone who was well versed in the mastery of traditional stories and proverbs was qualified for leadership and preaching. Such a person could use the many stories and proverbs to illustrate the biblical text.

Historically, AICs did not have institutions of theological training to train their personnel and even those that were able and willing to train in conventional theological institutions found themselves in contexts they did not feel they belonged to. Moreover, in many cases candidates were refused by institutions sponsored by the Mission Churches the AIC had seceded from, because of suspicion against these younger churches. ${ }^{3}$ Since the 1970s a number of AICs have trained and continue to train a few candidates in theological institutions sponsored by the established churches. The candidates, however, experience difficulties in connecting the training from conventional institutions with their experience and practice in AICs, as churches of belonging. Also, the clergy of these churches are involved in other employment as a way of support for the ministry work, which denied them training formally even if an opportunity for such training arose. AICs personnel supported managing the ministry by engaging in extra occupation because there was no systematic remuneration. In this regard, they objected to the notion of being referred to as part-time clergy as the work they did outside of the churches also always contributed to their ministries.

\section{The Organization of African Instituted Churches}

In 1978 the OAIC was founded in Cairo as an association of African Initiated Churches. The international headquarters of the OAIC are located in Nairobi, Kenya, where OAIC is registered under the Societies Act. The vision of OAIC is to facilitate those who are building on their African cultures and values and 
who are transformed by the Good News of Jesus Christ and are blessed by the Spirit of God to create an abundant life in community for their children and the world. OAIC's mission is to bring African Initiated Churches together in fellowship and to equip and enable them to preach the Good News of Jesus Christ in word and deed. The organisation works in seven regions: East Africa, Southern Africa, Madagascar, the Democratic Republic of Congo, West Africa Francophone, West Africa Anglophone and Nigeria. These regions are represented on the governing body, the General Assembly and on the Executive Committee. At country level, the OAIC works through chapters. OAIC has programmes in theology and ministerial formation, livelihoods and food security, just communities and health. The latter developed from HIV/AIDS work conducted by the organisation since the mid-1990s. The programmes are conducted with an emphasis towards women empowerment and youth issues. OAIC is an associate member of the All Africa Conference of Churches, participates in programmes of the World Council of Churches and in its central committee (in adviser role). Moreover, OAIC participates in the Global Christian Forum leadership and activities. The organisation also works in partnership with the Programme for Christian Muslim Relations in Africa (PROCMURA) on interfaith issues. More information can be found on OAIC's website (www.oaic.org).

\section{Theological education in OAIC}

At the formation of OAIC, the founding leaders identified theological education as one of the most important issues the African Initiated Churches (AICs) had to address. As outlined above, theological education among AICs had been largely based on apprenticeship and mentorship within the churches. OAIC consulted the World Council of Churches with an aim of starting a seminary for training AICs. The advice from the World Council of Churches was that using the Theological Education by Extension (TEE) methodology would be most beneficial to the AICs at that time. Hence, OAIC started a TEE programme in 1982. It was at a time when AICs were still very suspicious of theological education, as it was offered by seminaries established by Mission Churches. The 1980s became the founding phase of the programme. Students were brought to Nairobi and were taken through a training process that the OAIC was doing. This earlier TEE programme succeeded in engaging AICs and enabled them to acquire skills in facilitating TEE classes. It had a profound impact on churches in nearly all of subSaharan Africa.

The mid-1990s was a period of reflection and questioning the work of leaders in Bible studies and development of training materials based on the values of the various churches which participated in the training. In particular, questions arose whether the training done by the Theology Programme of OAIC was appropriate to AICs considering their identity, mission and context. OAIC recognised the fact that the church leaders were looking 
for an enriched training that would contribute towards ministerial formation. An evaluation was carried out and a pastoral training curriculum was developed. This moved the OAIC training programme from group trainings in churches to training pastors. In the new millennium, reflections on what is the appropriate theological education for AICs based on their founding visons (identity, mission and context) occasioned the OAIC Theology Programme to embark on developing a master plan for training theological education in AICs. The master plan has four major components: 1. curriculum, 2. production of training material, 3. resourcing for theological education and 4. quality control. The working definition of theology within the AIC setting leading the work of their trainings today is: 'Theology is people making sense of God in the midst of their histories, cultures, worldviews and contemporary struggles for survival' (OAIC 2005).

\section{Founding visions become theologies}

The idea of the 'founding vision' as a way of explaining AIC faith and theologies was first introduced at an OAIC workshop in Johannesburg in 1996. As its name suggests, the founding vision is created during the struggles of the founders to hear God's calling, and to obey it in the particular circumstances and communities in which they live. In subsequent generations or in different cultures, the community of faith faces new challenges. The founders themselves pass on, a new generation of leaders emerges, society changes, people have new expectations of the church. Moreover, in the process of handing on the founding vision from one generation to the next, it is often subject to change. Such changes are not always easily observable, since at the same time the cultures of church and society are also changing. Sometimes there is a shift in the dominant language or cultures of the church. For example, the church may have crossed political borders from one country to another, or the majority of church members may now live in multicultural urban settings instead of in rural areas.

Changes like these in the external environment often lead to divisions or disagreements in the church. It is at this stage that the leaders will normally begin a second process of reflection that is intended to do two things: first, recover and record the original teachings and vision of the founders. Second, elaborate or explain these teachings in a way that communicates them within the new social or cultural settings. This dual process looks to the past, and then uses what it has learnt from the past to engage with the challenges of the present and future. In this process of recovery and reflection, theology - the result of reflection on faith and its history amidst the challenges of the present - gains a distinct existence from religion or faith. Part of this process is to objectify the founding vision - i.e. to distance ourselves from the vision so that we can make it the object of our description and analysis. The purpose of the process is to develop a coherent description and explanation of our faith in the new circumstances - in fact, a theology. 


\section{Practical methodology of recovering, documenting and updating AIC theology}

OAIC has understood AICs' faith and traditions in terms of 'founding visions' the values, teachings and understanding of the world passed down from the generation of the church founders through the life, worship and ministry of the church. Much AIC teaching or theology is embedded in its founding vision and is rarely fully articulated or even properly recorded. The task of recovering a theology from prayers, songs, sermons, church rites, services, customs and history (the ways in which the founding vision is transmitted) has often seemed challenging. From an academic perspective, it seems to require a variety of technical skills drawn from disciplines such as history, ethnology, sociolinguistics and cultural studies. Unfortunately, asking for such elaborate and esoteric methodologies in practice disempowers AIC members lacking such skills or the resources to obtain them.

A simpler approach was used in a workshop of documenting a theological handbook of the Holy Spirit Church of East Africa (HSCEA) in 2016 that is currently in its final stages. The purpose of the handbook is to recover, document and update founding visions and sieve theological experiences that would be useful in training various theological topics. Retaining the concept of the founding vision as the source of AIC theologies, and building on recent developments in the study of local theologies (Bevans 2002; Lonergan 1990) and of orality, we began by recognising the fundamental nature of AICs as oral communities. This meant valuing the primacy of the lived text (the oral text) over the printed text as the raw data for our theologising (Lubaale 2017). We accepted that the church had already been using an oral theology in its life and ministry for several generations, and that our task was not to create a theology, but first of all to write it down. Respecting the orality of AICs was liberating. We learned that the form and content of an AIC theology must be appropriate to the faith community that owns it, and that the process of theologising (in this case, the group dynamics of the workshop) should respect the way HSCEA members actually worship and practise their life and ministry.

AICs are of different types. The HSCEA is a Spiritual Church, and specifically a member of a group of such churches with their origins in Western Kenya known as Roho Churches. We thus agreed that the Roho Churches' vision and orientation should influence the form, content and process of the workshop. Working this out in practice was both challenging and exciting. As facilitators, we made mistakes, but the end result was a workshop experienced by all participants as a time of particular blessing from the Holy Spirit. The workshop also provided a good foundation for developing a handbook on theology for the HSCEA.

\section{Notes}

1 To keep the terminology coherent throughout the volume, the term Initiated is used here. 
2 See the introduction to this volume for an outline of the different strands of African Initiated Christianity.

3 See Chapter 15 in this volume for the example of Good News Theological Seminary in Ghana, which managed to bridge the gap between Independent Churches and Mission Churches in theological education.

\section{References}

Bevans, Stephen B. 2002. Models of Contextual Theology. Maryknoll: Orbis.

Lonergan, Bernard. 1990. Method in Theology. Toronto: University of Toronto Press.

Lubaale, Nicta. 2017. 'Independents.' In Christianity in Sub-Saharan Africa, edited by Kenneth R. Ross, J. Kwabena Asamoah-Gyadu, and Todd M. Johnson, 252-263. Edinburgh: Edinburgh University Press.

OAIC. 2005. Facilitating AICs to articulate their theologies in the global context. A concept paper for the OAIC Department of Theology. Nairobi: Organization of African Instituted Churches. 
$\Longrightarrow$ Taylor \& Francis Taylor \& Francis Group http://taylorandfrancis.com 


\section{Part II}

Nigerian perspectives 
$\Longrightarrow$ Taylor \& Francis Taylor \& Francis Group http://taylorandfrancis.com 


\title{
6 Distinguished church leader essay \\ Roles of women in African Independent and Pentecostal Churches in Nigeria
}

\author{
Atinuke Abdulsalami
}

\section{Introduction}

African Initiated Christianity came into being in Africa through the initiatives of the concerned Africans who felt that Christianity should better be expressed in the African perception and worldview. This initiative was deployed to wipe out factionalism and bring together African Christians with their African feelings and passions towards generating African thoughts in Christianity. This strategy was necessary to connect the gulf created by the 'foreign evangelists' who came to 'pioneer' a Christianity that was incompatible with the sociocultural and sociopolitical worldview of the continent.

\section{Distinction of Pentecostal and African Independent Churches}

The Pentecostal Churches in Nigeria were virtually all founded by Nigerians. This as it may, it is difficult to separate the Pentecostal from the African Independent Churches. They can all be considered different branches of African Initiated Christianity. But the Pentecostal Churches in Nigeria can be described as churches modelled around the modern American churches because the founder had been in theological schools in the country or chosen to follow the style in worship, music, sermons etc. In this way, they are able to relate to a class of people in society, e.g. the elites, middle-class, foreign-educated Nigerians who needed spirituality but in a form that they are comfortable with. The founders are usually theologically trained.

On the other hand, the African Independent Churches in West Africa - for example 'the white garment churches' - are more indigenous in their approach to Christianity. It brings Christianity to the grass roots in language, music, dance, spirituality and much more with which they are familiar and comfortable with. The founders of these Indigenous Churches are rarely students of theology. They are more often than not of a highly spiritual nature.

The precepts of the two types of churches are similar, as they believe in the Trinity and the word of God. The likely explanation of the existence of both types of churches is that they both reach different strata using different approaches. This however is not the focus of this chapter: the roles women are 
playing in these two churches in present-day Nigeria being the object of this discussion. Being in a privileged position as the founder of Divine Salvation Bible Church (an African Independent Church), I believe my position in this discussion will not be undermined.

\section{Women's roles in the early African Independent Church and Pentecostal Churches in Nigeria}

\section{African Independent Churches}

The African Independent Churches as earlier described as Indigenous Churches, seemed to have had parallel roles for the male and female leaders from the start. Maybe this is because before the advent of Christianity, women had led in spiritual rites and worship in the native and traditional beliefs as priestesses, for which reason in African Independent Churches female leaders became readily acceptable, and became instrumental in the welcoming of the faith of our Lord Jesus Christ in Nigeria. So, one can say the traditional roles of women in the African Independent Churches were not hindered by the doctrine of Paul as such but were acceptable as a norm in the Nigerian society of old. The women could minister, pray with and for men, they taught the Bible and did not have to sit in silence when men were talking. There was no gender inequality to stop them from being the Prophetess Deborah (in the Old Testament) and the Samaritan woman (in the New Testament) of their time.

\section{Pentecostal Churches}

The advent of Pentecostal Christianity in Nigeria would naturally have been expected to address gender inequality (being a more modern and imported approach to Christianity) and be different from the Mission Churches' style, whereby 'women are seen, not heard'. However, contrary to that expectation, women were still marginalised in active participation of any spiritual or religious aspect of ministry in the church. Women were not welcome on the pulpit in a congregation that sits both sexes.

Rather, women were often behind the scenes. They were expected to teach at the children's Sunday school, join the choir, be in the welfare section, do administrative work or just sit at the altar with the 'husband/pastor', nodding and cheering in support of his sermons and much more. A school of thought holds that the Apostle Paul had unequivocally stated 'women should remain silent in the churches. They are not allowed to speak, but must be in submission, as the law says' (1 Corinthians 14:34). In another scripture, he states 'I do not permit a woman to teach or to assume authority over a man; she must be quiet' (1 Timothy 2:12). With the obvious fact that most of the Pentecostal Churches were styled around the Apostle's ministry, most have held on to that doctrine that a woman cannot teach, let alone preach in church. Therefore, the traditional role of women according to the scriptures à la Paul the Apostle was the practice in Nigerian 
society. It limited the potential of women to minister the word of God with passion like Prophetess Deborah and the Samaritan woman at the well.

\section{Roles of women in modern-day African Independent and Pentecostal Churches}

\section{Women in African Independent Churches}

Although we have it on record that African Independent Churches had always encouraged women's participation in ministry and have enjoyed equal opportunities with men to serve in leadership roles, the elevated positions of these women in their churches have allowed steady growth, so much so that about 70 per cent of membership is female.

The spiritual care and growth of faith in the ministry of the Lord Jesus is well impacted. Although the African Independent Churches may not have too much of a financial base because their churches are local and not usually found in highbrow and elitist areas unlike their counterpart churches, they are closer to the grass roots and the underprivileged. More often than not they are unable to give financial support but have excellent ministry of welfare and spiritual care for both genders.

African Independent Church women have been able to nurture souls through the spiritual gifts that accompany their ministries vis-à-vis visions, prophecy, trancing and sermons. They usually have an efficient welfare group ministering to the needs of widows, miscreants, homeless, etc. and are playing beneficial roles in the community by providing basic needs like water pumps, schools for the less privileged, health visits, meagre financial support, spiritual support to the elderly and much more. These are some of the ways in which they are able to serve their communities, especially because they are within that neighbourhood. Such areas are usually in the suburbs and these women see the need more regularly than the people, such as charity organisations, who only go there at Christmas or Easter. They are their brothers' keepers.

\section{Pentecostal Churches}

Looking back at the roles of women at the advent of Pentecostalism in Nigeria, there seems to be little or no shift from the 'siddon look' (sit and watch) syndrome even in spite of modernisation of churching in Nigeria in the last 30 or so years. There is still the laidback style of not much involvement of females in the Mission Churches; they still play virtually the same roles. In recent times however there seems to be a visible emancipation of Pentecostal women leaders prominently heading fellowships. It is obvious that they have tactically taken 'church out of church' by catering for the needs of more faithful women that are gathered in groups now identified as fellowships. Women are coming to the realisation that there is a 'not too hidden scripture' that puts them on the same pedestal as men in ministry: 'there is neither Jew nor Gentile, neither slave nor 
free, nor is there male and female, for you are all one in Christ Jesus' (Galatians 3:28). They now know and accept equal rights to minister the gospel of Jesus Christ, though subtly.

For such reasons listed above, opportunities to gather women and focus on socio-religious matters which the churches were not able to address began to grow, such as Married and Singles Fellowship, Praying Mothers Fellowship, Daughters of Abraham Fellowship, Women of Prayers in Nigeria Fellowship (of which I am the initiator/president), Sisters Fellowship International and many more. An upsurge of fellowships began to be the approach of the modern female Pentecostal leaders to break loose from the shackles of the puppet in a box. Since the advent of women fellowships, the groups have in their own way impacted the lives of women in and outside of the churches. They have taught them scriptures to suit their particular situations and also given the necessary support financially, politically, medically, emotionally, even academically and in many more beneficial ways. They have been able to minister to the needs of the underprivileged and even become relevant in society.

Unfortunately, the Pentecostal women leaders have almost virtually restricted themselves to the middle-class females; most of these fellowships became a gathering of the elitist and the learned. They are more philanthropic towards and are usually only seen at the grass roots as charity organisations. 'They provided bread not the bread of life' (Matthew 4:4). They almost limited their words and works to their fellowship meeting days. Most of the initiators of these female Pentecostal fellowships are not heads of churches. They are usually the wives of the head of their church, so their groups are funded by their mother church. They are still branches of their main church excepting a few women who per chance took over after the demise of their husband/founder, for example Bishop Mrs Margaret Idahosa, Rev. Mrs Roseline Oduyemi, to mention a few. Be that as it may, these fellowships have been a feeder source for the mother churches, so the women have impacted growth through that subtle approach.

\section{Hindrances and recommendations to effective and impactful roles of women in the African Independent and Pentecostal Churches}

\section{African Independent Churches}

1 Due to its African disposition, Christendom has continued to underestimate the abilities of these African Independent Churches, especially the perceived 'white garment churches' to be worthy of association, forgetting that Jesus Christ has said 'He came that we may all be one' (John 17:21).

Recommendation: lines of segregation should be removed in African Christianity. Every church should be seen as working for Team Jesus, to achieve a common goal of winning souls and keeping them for the Kingdom of God. All should work together not as strongest or weakest link, not as male or female but as a force to be reckoned with in the communities and society at large. 
2 African Independent Churches' women leaders face huge financial insecurity to sustain their passion for evangelism, through outreach, crusades, welfare etc., because the membership of such churches due to its locations, language, social status and more are the receivers not the givers.

Recommendations: the government should have in addition to their rural development plans consideration for the growth and sustenance of the local churches by financially supporting them in the provision of good-quality neighbourhood schools, hospitals at affordable prices, etc. NGOs should work closely with these local churches because they are within the community and know what is needed by the people on the ground. Bigger, urban churches should adopt these women-led African Independent Churches without interfering with their theological stands but through them support the social and welfare of the community in which they serve.

3 Most women in the African Independent Churches are not educated but could do with educational opportunities in theology.

Recommendation: theological schools should encourage women to come and learn at affordable prices. Confidence should be built and assurance given that they will not be sidelined.

\section{Pentecostal Churches}

1 Basically, non-recognition of women as equals in the Pentecostal ministry has hidden their God-given ability to win and keep souls.

Recommendation: the Pentecostal Churches should allow women gifted in ministry to exhibit the grace upon their lives. They should be equipped and empowered and set for success in ministry by the church authorities.

2 In Pentecostal Churches, their ministries have been undermined and limited to socio-charity organisations. They do not have adequate connection with the real needs of those that are less privileged in society.

Recommendation: women should not remain in the tag of charity alone; they should be allowed equal rights in ministry so they can also expound on other arms of the complete church.

3 They have been denied quality leadership roles which would have put them in the advantage role of bearing good fruits and keeping them. The charisma associated with women of God, which is exhibited when they minister passionately, is also hidden.

Recommendation: women have soul-winning abilities; the church should recognise that. This is evident in the growth and impact of the fellowship meetings they have initiated.

\section{A personal testimonial}

Born 'Adijat Ajala' as a Muslim to fairly staunch Muslim parents and married as Hadiza Abdulsalami to a Muslim man, I would say before my salvation, my real vivid knowledge of any other Prophet other than Mohammed (S.A.W. - Peace 
be upon him) was at the age of nine years, when I watched on television in those days the late great tele-evangelist Billy Graham (Hour of Decision). He talked about Jesus with so much energy and tenacity and above all passion. I saw people come to the altar to accept Jesus Christ as Lord. Maybe I was just fascinated, but I stole the 30 minutes every Sunday to watch and listen to him. Many years after, I attended a mission school because of the quality of the education. I remember my father warned me sternly not to get involved in any religious activities and he came to school with me quite a few times to remind the authority that I was a Muslim. I was an all-round student in virtually all activities but Christian-related curricula.

One day about two years out of college, I was barely 18 years old, after I had gone to bed, something unusual was happening among the other members of the family that were 'merry-making' during the New Year festivities. Two of them began to speak in tongues. It was unusual and so it looked funny, I was awakened to join in the fun, but lo and behold, I began to speak in tongues and translated everything that was uttered. As strange as it was, my parents who were present were shocked at the utterances because it spoke of things they never mentioned to us as children and also about their past and present. After that day, there was never another visitation. It could not be explained in Islam, so we pretended it never happened.

About 10 years after this experience, I went to have my baby. My pregnancy progressed and was easy until the day of the delivery. The doctor checked and concluded I needed surgery. That was the beginning of my story. Within an hour of his visit, I became an entirely different person. I saw things no one saw, I heard things no one heard! The family that were with me were confused; they did not understand. They began to make contact with Muslim clerics and others to pray for me.

I began to reveal and repeat what I was seeing and hearing. I saw four strange apparitions and asked them who they were. They told me they had come to help me have my baby in transition. No one else saw or heard them. I was at peace all through, I had no fear or anxiety. This went on for a while. Finally, I asked my husband for a pen, that I had been instructed to write something, which I inscribed on my palm and my fist was clenched and could not be opened by anyone. I was taken to the theatre for the surgery, with all others panicking and hoping with all my show I would come back alive. Alas, at the surgical table my body was dead; 'I' was out of it. I saw the doctors make frantic efforts to revive me and I noticed that the anaesthetist was the only one praying in Jesus' name for a miracle. I said, 'He does not know, that "it" [my body] is dead, and only God can revive it.' They gave up on me and covered 'it' (my lifeless body). I saw my baby taken away. At that moment, the real transition began.

Out-of-body experience, science calls it. For me it was the great encounter. I found myself on an entirely different plane. I could see people burning in a fiery furnace, wailing, crying and gnashing their teeth, no one was guarding the entrance but they could not escape! Second phase, I looked down from above and saw people weeping. The fat and the slim, the rich and the poor, the young 
and the old, the pregnant and the barren, everyone was crying. I asked, 'Why is everyone crying?' The answer was that, 'The whole world will weep until they come to the knowledge of God.' At the third phase, I was taken to another sphere where there was void, no crying, no wailing, no hunger, no sickness, I wanted to remain there, but I was told, 'You have to work to be here.' Moving from these three planes, we arrived at a place they told me was the judgment seat! I had never heard of such a thing! And a mighty book was opened, I was curious at its size and I asked what it was about. I was told it was the book of life, where a record is kept of all my deeds. And a loud voice read aloud, 'On this date [mentioned] and this time [mentioned] you said to this person [name mentioned] that you will never forgive him.' It was true! But no one was there with us, it was a reaction, how did it get here? My mind flashed and began to race back to the hellfire I saw earlier; I am doomed! 'True?' the voice firmly asked awaiting my response. I said 'Yes'. I was awaiting further reading, none came, it was time to face the judge! But I was curious, I needed to know so I asked, 'Is there no record of even one good deed I had done?' I got an instant answer, 'Good deeds are not recorded, your purpose in life is only to do good. Anything contrary is recorded and will be judged.' And that was it. So many other incidences transpired but I will fast forward to how I was saved from hell.

Where I stood, I felt the presence of something or someone extraordinary, please do not ask if it had a face or not. I could feel the presence, I was trembling and realised there was no escaping judgment, a gentle voice said to me, 'I am the advocate, I can set you free.' It was hard to believe who could save me from here. And I retorted, 'I do not even know you,' he answered, 'I knew you before you knew me.' 'If you believe in me, I will speak to Him [judge] and your records will be clean.' At that point in time, I desperately needed the offer of a new lease of life. I said, with every strength in me, 'I believe'. He said, 'Now that you have accepted that I can save you, what will you give in return?' Without much ado, I stuttered 'I will go and witness all over the world, that you are Lord and no one else.' 'I will fulfil my side of the covenant, if you fail your side, I will be back in four days,' he said. And, in a jiffy, I was back where my body was laid; I had been saved! I entered the body and requested, 'Let my right foot move, so they know I live.' And so it was. I could hear the nurse calling my name like from afar. 'Hadiza [my Muslim name, which was the name of the wife of the Prophet Muhammad], are you here, can you hear me?' All I could mumble through it all was 'Jesus is Lord', repeatedly.

Later in the room that night, the surgeon and anaesthetist came to visit me. The first question I was asked was 'Are you a Muslim or a Christian?' I confirmed myself as a Muslim but they told me how I had confessed Jesus as Lord during my surprising revival. At that time, the doctor said 'give me her chart, nurse, time of resuscitation please?' And she answered, '7.19 p.m.'. Suddenly my palm opened and that was the exact time I had written in my palm four hours earlier. Everybody at that moment was a witness, even my husband was shocked. I enjoyed his support throughout. In spite of not converting, he believed in the Lord Jesus with that experience. 


\section{Atinuke Abdulsalami}

That is my witness. I have a mandate to proclaim the saving grace of our Lord Jesus Christ to the world. How could this be achieved if I were a Pentecostal woman in ministry? Would I have had the opportunity to win souls and touch lives as much as I have today, if I were under a man's authority and control? No one else experienced what I experienced and so they can never tell it the way I would. It was my testimony, like the Samaritan woman, and it is for me to run with the vision and share with the whole world.

\section{My role as an African Independent Church leader}

I did not come into Christianity by personal evangelism, theological studies or exposure. Neither was it by choice. I became a Christian from the above testimony by grace through a personal encounter and the salvation of my soul through the Lord Jesus Christ. For this I am eternally grateful. During the period of my search on how to impact my testimony, the only place where I found acceptance was in an African Independent 'white garment' Church - New Temple Spiritual Church, Banire, Lagos. I was taught about Christianity, I was accepted the way I was and was baptised through the church. I grew in ministry and was ordained as an evangelist and, later, a prophetess.

When it was time to begin the work of an evangelist my testimony birthed the Evangelical Church of Divine Salvation Bible Church (a.k.a. Divine Salvation Bible Church) some 23 years ago at 5 Adewusi Street, Fadeyi, Lagos, Nigeria, which is duly registered and identified by the Nigerian government as an African Initiated Church. The church did not start overnight; it began with sharing this testimony to one, and then two and more in my living room. People urged, 'Teach us about this Jesus.' I shared my knowledge not from the word because I knew next to nothing then, but through the encounter. More people came and were encouraged; they also went about sharing this testimony until we reached the den of thieves and drug addicts. They welcomed us and were anxious to know about Jesus. They refused to let us leave until we promised we would visit them every Sunday. The rest is history because in that same lion's den, the lion of Judah became king. This eventually led to the building of a meeting place, the church. This became another home for all in the community. Today, encouraging both males and females ready to serve and carry out the five arms of the church (apostolic, evangelical, pastoral, prophetic and teaching) and my personal roles and functions as the Leader of Divine Salvation Bible Church has led to impacting individuals, the community and a steady growth and development of the church in the last 23 years.

\section{The sustainable approach to church growth through theology and development: my methods}

Credited with the above achievements the following are some, but not all, of the activities that have sustained the growth of the church in the community. In addition to the five arms of the church these regular interaction and support 
activities which are essential to the spiritual growth of the individual members have in no small measure impacted the expected expansion both spiritually and physically.

1 Sunday worship;

2 open-air crusades;

3 ordination of other ministers including women;

4 welfare and visits;

5 performance of marriages, funerals, baptisms and christening ceremonies;

6 Bible study and prayer meetings;

7 monthly seminars for the youth church;

8 prayer ministration for pregnant women;

9 care of widows and the elderly;

10 free health programmes and check-ups;

11 evangelism;

12 empowerment of widows and youths;

13 community development and much more;

14 trancing;

15 literacy initiatives; and

16 social activities such as Easter picnicking, Christmas carol singing.

\section{Achievements as an African Independent Church woman leader}

Ministry: in the church I have been able to dispel the mindset that women are not visionaries. Men and women alike have sat under my ministration and have been positively impacted. Several have been converted through my outreach and crusades, and have become very active members of the church and useful hands in ministry. I have personally through ministry bridged class distinction by making all welcome to church the way they are. Moreover, with my background in Islam, I have been bold enough to preach against and mediate in religious intolerance, not only locally but even on national television. I have resolved communal conflicts that erstwhile elders in the community had been unable to resolve. I have through the bible school of my ministry trained, mentored and ordained more women than men for ministry. Many of them have gone ahead to found their own churches and continue to proclaim the good news of salvation. I have also initiated the Women of Prayers in Nigeria Fellowship, to bring women into the limelight by being vocal in the country and praying for our government, community and family regularly.

Christendom: it is my considered opinion that through my ministry more men of God have come to the realisation that women if given the necessary support can equally move mountains through the word of God. I have received awards too numerous to mention for community service and ministry, the most recent being an invitation to be the Secretary of the Board of Trustees of the Fellowship of Christian Ministers Nigeria, the very first indigenous gathering of 


\section{Atinuke Abdulsalami}

Nigerian ministers. The greatest privilege is my being the very first female office holder in its 106 years of existence. By now our church sits among male church founders in many Christian associations, e.g. Fellowship of Christian Ministers Nigeria, Organization of African Instituted Churches, Bible Society of Nigeria and many more, where I am accorded due respect.

Society: my ministry has been able to impact on the larger society by being contributory to the development of the community vis-à-vis social welfare, provision of potable drinking water, regular health check-ups for all, health education in times of epidemics or breakout of diseases, mentoring and empowering widows and much more. These services are given regardless of background, class or religion. Most of this I have single-handedly financed and occasionally solicited for assistance from well-to-do friends and family. I would have explored the possibility of founding a good-quality primary school and hospital in the neighbourhood, but I have been financially constrained after becoming a widow three years ago and burdened with the further responsibility of single-handedly taking care of my children.

\section{Conclusion}

Women when allowed to exhibit their leadership skills have never failed to be crowd-pullers. They have the charisma to attract attention, they are natural teachers. Women have been limited by some men's limited imagination. The native intelligence our mothers used in the African settings of old to raise today's world leaders is being undermined. Women are home builders, so why would they now fail as ministry builders? If women can be allowed on the sociopolitical scenes all over the world, what is wrong in allowing them to have impactful roles in ministry, especially women who have visions and missions? Women need to be prepared, equipped, empowered and positioned for success in ministry. We have a lot to offer. It is time for a paradigm shift. There is space for all in the ministry of salvation. Jesus did not undermine women, He fulfilled ministry through every available vessel, both male and female. Personally, I would want to opine that Paul the Apostle's idea of women keeping quiet was directed at the type of women that were present there (maybe they literally had no value at that gathering). Maybe in different circumstances he would have said, 'Men, be quiet, let us listen to the Prophetess Hannah.'

I would like to close with a quote by Christina Lee, the first KoreanAmerican female pastor in the Episcopal Church, who said, 'If the church followed the example of Jesus in how he treated women, it could heal the world.' I could not agree more. 


\title{
7 'A starving man cannot shout halleluyah'
}

\author{
African Pentecostal Churches and the \\ challenge of promoting sustainable \\ development
}

\author{
Olufunke Adeboye
}

\section{Introduction}

The subject of poverty and underdevelopment in Africa has been the focus of several publications, global summits, academic conferences and numerous research efforts within and outside the continent. The governments of various African states have also had to contend with these issues from time to time. While scholars (such as Addo Fenning 2003; Anyanwu 2003; Bornstein 2001, 2002) have devoted much effort to the activities of foreign sponsored Christianity in addressing these issues, not much has been written about the response of the African Pentecostal community. Again, in Oladipo (2000) Pentecostal activity is subsumed within general discussions of the 'African Church'. This chapter departs from this general treatment and focuses exclusively on African Pentecostalism. Again, the idea of starvation mooted in the title of this chapter is presented at a generic level. Starvation here represents not only deprivation of food, but also of basic social amenities, of security, and of a good livelihood. Any person caught in this web of lack can hardly be expected to jump in typical Pentecostal ecstasy with no hope of improvement in his/her material condition. The challenge before the Pentecostal community is thus to find solutions to material as well as spiritual needs in their social environment. How have African Pentecostals responded to these social needs? How much of the social space is taken up by Pentecostals and what networks do they exploit as they strive to meet these needs? And, most importantly, what ideological, theological, relational and material hurdles do they have to scale as they continue to grapple with issues of sustainable development?

This chapter is divided into five sections. The first section provides a general background by historicising Christian social work in Africa. It provides an overview of missionary activities in the nineteenth and twentieth centuries. It also examines the entry of Christian NGOs in Africa into social work in the late twentieth century. The second section examines the origins of African Pentecostalism and how much of social work featured in their initial activities. The third section attempts to situate the global idea of sustainable development within local paradigms. Is there a point of convergence between global discourse 
on sustainable development and Christian thought on the same issue? What exactly is being 'sustained' in the idea of sustainable development? The fourth section presents a case study of the social work of the Redeemed Christian Church of God, Nigeria, through their Christian Social Responsibility (CSR) platform. How does Christian Social Responsibility differ from corporate social responsibility practised by the business community? What theologies underpin CSR? What attempts were made to institutionalise these interventions and make them sustainable? The final section examines the key challenges confronting African Pentecostal Churches involved with sustainable development.

\section{Historicising Christian social work in Africa}

Social work promoted by foreign missionaries from Europe and America in subSaharan Africa in the nineteenth and twentieth centuries was multifaceted. It covered education, health, agriculture, trade and campaign for the emancipation of slaves and pawns within their message of egalitarianism. Barthel (1985, 140) argued that first the schools in Senegal were established in 1816 by Catholic Sisters of St. Joseph de Cluny, a teaching order, in the Island of Goree, and the coastal city of St Louis while the first school in Gambia was established by the Methodist Church in 1826 in Bathurst, now called Banjul. Similarly, the first primary schools in Nigeria were founded in the 1840s by Methodist and Church Missionary Society (CMS) missionaries. In Sierra-Leone, apart from several elementary schools, the popular Fourah Bay College, founded in 1819 was originally meant to train men for the CMS ministry, but later expanded into a liberal arts college. In all these and other parts of Africa, the primary concern of the missions was the planting and nurturing of Christianity. Jordan $(1949,82)$ observed that one of the missionaries, Bishop Joseph Shanahan who served in Igboland, Nigeria (1902-1932) opined that:

The school is becoming more and more a providential instrument of incalculable good in our hands. If we go from town to town talking only about God, we know from experience that much of our effort brings no result. But no one is opposed to the school.

Elsewhere, in the Gold Coast, it was noted that public street preaching by missionaries to win adult souls yielded marginal results. Addo-Fennings's (2003, 197-198) description of these exertions is graphic:

In 1877, for example, the Rev David Asante of the Basel Mission at Kyebi, between himself and his Catechists, travelled 190 days preaching in 50 towns and villages in Akyem Abuakwa. The results of such exertions, however, remained incommensurately small up to the late 1870s. Street preaching was little patronized. An audience of 10 people was a good attendance. Not frequently, there were no listeners at all. Most free-born adults showed little interest in Christianity and often demanded pecuniary inducement as a condition of becoming Christians. 
However, the highest numbers of converts were won among pupils in the various mission schools. A majority of them ended up being baptised. The pupils were also used as 'part-time' evangelists to reach out to their communities. From the above, it is clear that schools provided an avenue from which Christian converts could easily be raised.

In addition to education, missionaries made giant strides in the field of public health. In the twentieth century, many of them had big hospitals in different parts of Africa. But the beginnings of their health endeavours were very humble. They started with clinics and dispensaries attached to schools and mission homes, where they treated wounds and other ailments for free. They also popularised scientific medicine and improved sanitation in their communities. In fact, many nineteenth-century African church leaders were expected by their local communities to respond to medical emergencies with the white-man's medicine as indicated in the experience of an Ibadan-based Yoruba CMS local agent narrated below:

Early this morning, there was a great noise not far from my house. I stood out and saw people running. On inquiring, I was told that two brothers fought together and the younger stabbed the elder with knife and forced his bowels open. Immediately, I was sent for, and met the young man half dead. I told them I am not a doctor, but however, I shall try. It may be the Lord will save him alive. I sent for needle and thread, carefully pushed the bowels in and sewed it up and sprinkled vinegar on it and covered it with plaster. The fourth day, I opened it and dressed it. Within three weeks, the wound was healed. I was since then looked upon as a Surgeon. This man promised that if he should get better from his wound, he shall regularly attend the house of God. Oh, how soon did he forget!

(CMS, 1877)

A good illustration of missionary efforts in the area of agriculture is that of Wesleyan and Basel Missions in nineteenth- and early-twentieth-century Gold Coast, later Ghana. These missions encouraged their converts to become economically self-reliant by engaging in agricultural activity. Apart from providing practical agricultural training for pupils in school farms, they also had special agricultural training centres for Christian farmers. They introduced a new range of cash and food crops to their converts. These included mangoes, pears, oranges and cocoyam for the food crops, while the new cash crops included tobacco, coffee, cotton, rubber and cocoa. A Basel Trading Factory at Christiansborg in 1855 bought agricultural produce from Christian farmers and arranged shipment to Liverpool and elsewhere. An interesting view was expressed by AddoFenning (2003) who articulated that this act not only encouraged Christian farmers, it also inspired other converts to 'take to private trade as retailers or brokers for Accra-based European firms' (197). By the beginning of the twentieth century, cocoa had already become a major income earner for Christian farmers in Ghana. 
Early missionaries also campaigned against the practice of slavery and pawning in various places in Africa through their message that all men were equal before God. The Basel Mission in the Gold Coast had an Emancipation Fund from where willing slaves and pawns were given loans to purchase their freedom. Such beneficiaries almost invariably became Christians (AddoFenning 2003, 198). This was not without attendant social complications as 'indiscriminate conversion' of royal slaves provoked the hostility of traditional political authorities (Addo-Fenning 2003, 198). A second source of complication was the non-compliance of some members of the Christian community with the egalitarian message. A case in point is that of Mrs. Allen, wife of one of the Yoruba CMS Pastors serving in Ibadan. CMS (1879) and McIntosh $(2009,96)$ shed light on a fellow missionary and complained in 1879 of her use of personal slaves to run her business located in another town, far from her husband's station. Such defiance from highly placed leaders, when discovered within their local community, discredited the Christian message.

In any case, the social work of the church continued throughout the colonial period. In fact, the missions remained a dominant influence in the growth of educational institutions. After independence, many African governments in the 1970s took over these educational institutions from churches, in addition to establishing many more. The explanation often given was the need to maintain uniform standards, as many mission schools appeared starved of their previous foreign assistance. This was especially the case in Nigeria, Ghana, and a few other African nations (Anyanwu 2003, 72-73). Moreover, the logic of independence meant that postcolonial governments had to assume more responsibilities for education, public health and other social services. However, the economic crisis experienced by African states in the 1980s left its mark on the educational sector. As various African governments sought the assistance of the World Bank and the International Monetary Fund, the Structural Adjustment Programmes they were made to implement, among other things, prescribed acute budgetary cuts. This affected the funding of education, even as user fees were paid by students from the primary to tertiary level. Schools consequently became underfunded, ill-equipped and poorly maintained. This also affected hospitals and other welfare services under the purview of the state. On the whole, all these translated to daily economic hardship for the populace (Bourne 2015, 160-168; Campbell 2010, 11-22). This was the background to the rise of NGOs, both Christian and secular, to fill the service void created by the state.

Christian NGOs are particularly significant because they continued the tradition of missionaries who promoted social and economic development in various parts of Africa. Woolnough (2011, 195-205) has traced the rise of Christian NGOs globally to the 1960s. Since then, they have assumed a direct responsibility for relief and development to tackle the needs of the poor around the world. Many of them operate in Africa and are funded by external charities, foundations, churches and individuals. Their pursuit of economic development is done within a Christian context that emphasises salvation in all its 
ramifications. Commenting on the activities of two Christian NGOs: World Vision and Christian Care in Zimbabwe, Bornstein $(2002,9)$ notes:

by presenting Christ with boreholes and irrigation schemes, World Vision provides a moral, and Christian, interpretation of economic transformation. Economic development serves a dual purpose; to introduce Christian beliefs to individuals, and to 'redeem' the earth to its 'God-given potential'.

\section{African Pentecostalism: origin and initial focus}

Ogbu Kalu has identified the Pentecostal movement as the 'third response' of Africans to mission Christianity. African Pentecostalism embraced the 'spiritual ecology' of Africa as mapped out in its traditional worldview (Kalu 2002, 110-137).

Asamoah-Gyadu (2007, 340) was of the opinion that the precursors of the Pentecostal movement in Africa were 'indigenous prophet figures' whose uncommon spirituality had earned them immediate expulsion from their respective Mission Churches. These men included William Wade Harris of the Gold Coast, Garrick Sokari Braide of the Niger Delta in Nigeria, Simon Kimbangu of the Congo and other such itinerant prophets who preached the Christian message with unusual authority; challenging witchcraft, sorcery and the powers of traditional religion, and healing various categories of sicknesses. These prophets never directly founded churches but were hounded by colonial authorities in their respective countries because their rising fame and large followership threatened the state.

There were also external connections and rapport between African and global Pentecostalism. This did not necessarily produce increasing homogeneity between both sides but rather provided a platform for Africans to domesticate and adapt various foreign ideas and practices to their own culture. Thus, by the end of the twentieth century, African Pentecostalism had greatly diverged from what it was in the 1930s when it started.

This brings us to the task of classifying various Pentecostal ministries in Africa. While the classification offered below may not adequately reflect Pentecostal diversification in the whole of sub-Saharan Africa, it is nonetheless true of West Africa. Two broad categories can be easily identified, each with its own further subdivisions. The first is the group of classical Pentecostals while the other comprises Neo-Pentecostals. Classical Pentecostals can be subdivided into two: indigenous and foreign. Examples of indigenous Pentecostal Churches are the Christ Apostolic Church in Ghana and Nigeria, the Church of Pentecost in Ghana (treated in depth in Onyinah, Chapter 12, and Anim, Chapter 13, both in this volume), and the Deeper Life Bible Church, Nigeria. Examples of foreign Pentecostals include Assemblies of God, the Apostolic Church and the Foursquare Gospel Church, all having branches in various parts of sub-Saharan Africa. Furthermore, the rise of various indigenous classical Pentecostal Churches cannot be located within the same temporal milieu. While churches 
like the Christ Apostolic Church and the Church of Pentecost emerged during the colonial period, others such as the Deeper Life Bible Church and the Mountain of Fire and Miracles Ministries emerged in the 1980s and 1990s. Different socioeconomic circumstances aided their rise and later popularity.

Classical Pentecostal Churches emphasise the Christian experience of the new birth and personal holiness exhibited in a moderate lifestyle with strict social ethics. These churches promote conservatism in dressing and physical appearance of women: no excessive jewellery, no make-up and no exposure of hair during services. It is only recently that some of these rules have been relaxed in order to attract more youth into the churches.

The second category of Pentecostals in Africa comprises Neo-Pentecostals. This cluster is made up of: trans-denominational charismatic fellowships mostly found on school campuses, renewal movements in historic mission denomination such as the Catholic Charismatic Renewal, and Charismatic Churches. Neo-Pentecostal Charismatic Churches have become very prominent in Africa since the 1970s and 1980s. Examples of such churches include: The Church of God Missions International founded by the late Benson Idahosa, Winners' Chapel founded by David Oyedepo, Christ Embassy International led by Chris Oyakhilome and Daystar Christian Centre founded by Sam Adeyemi, all in Nigeria. Ghanaian examples include the International Central Gospel Church founded by Mensah Otabil, and Lighthouse Chapel International led by Dag Heward Mills (Aiyegboyin 2018; Aiyegboyin and Ishola 1997; Aiyegboyin and Ukah 2002; Anderson 2001).

Other African examples include: Family of God Church led by Andrew Wutawunashe and Jabula New Life Covenant Church led by Tudor Bismark, both from Harare, Zimbabwe; Abundant Life Faith Center, Kampala, Uganda led by Handel Leslie, and the Redeemed Gospel Church, Huruma, Kenya founded by Arthur Kitonga. South African examples include the multiracial Rhema Bible Church, Johannesburg, founded by Ray McCauley, and Grace Bible Church led by Mosa Sono.

The RCCG straddles both the Classical and the Neo-Pentecostal divide. At its foundation in 1952 during the colonial period, it exhibited characteristics of Classical Pentecostals. But with the rise of its 'model' parishes in the 1990s and their rapid proliferation thereafter, it has taken on the features of a NeoPentecostal organisation with its urbane outlook and continuous engagement with developmental issues. However, some parishes retain the old outlook, and are in fact called 'classical parishes' within the larger organisation.

No doubt, all these churches - both Classical and Neo-Pentecostal - are fully committed to evangelism and soul winning. They are also concerned with the material well-being of their members though this is expressed in diverse ways. In many of these churches, concern for the health of members is shown in the healing ministry of the lead pastors. There was the case of Joseph Ayo Babalola, one of the founding prophets of the Christ Apostolic Church in Nigeria. The Pentecostal revival that he pioneered in Northeastern Yorubaland in the late 1920s drew large crowds for healing. Because of the size of the crowds, open 
fields were used for the meetings and nearby streams and rivers were consecrated for use as holy water for healing purposes (Olayiwola 1995, 137-149). The ministry of Benson Idahosa in the 1980s and 1990s also witnessed spectacular healing miracles as he went across Nigeria and travelled to other African nations to conduct large Pentecostal meetings (Garlock, 1981). Many observers considered the demonstration of Pentecostal charismata within this period as unprecedented, and therefore interpreted it as representing a special move of God. Within this context, other social intervention schemes were very minimal. African Pentecostalism already generated immense spiritual capital in the form of healings and other types of miraculous manifestations.

African Pentecostal leaders also demonstrated concern for the poor social conditions of their members through the propagation of the 'prosperity doctrine'. This doctrine can be situated within the Faith Gospel or message of Abundant Life which focuses not only on the bliss of the 'hereafter' but also propagates the flourishing of the believer while on earth. Maxwell $(1998,350)$ argued that the prosperity gospel gave people a template for coming to terms with and benefiting from modernity's dominant values and institutions. In a study on Pentecostalism in Kenya, Parsitau and Mwaura (2010,95-112) argue that one of the reasons Pentecostalism became popular in urban Kenya was because of its capacity for social transformation and change. Pentecostalism empowered marginalised classes and facilitated upward social mobility for several individuals through the instrumentality of the prosperity gospel preached by Kenya televangelists such as Bishop Mark Kariuki, Bishop J. B. Masinde, Margaret Wanjiru and Wilfred Lai. The urban poor are attracted to this message because Pentecostalism claims to have an answer for poverty. When this is juxtaposed with the failure of the state as an agent of modernisation, it thus makes sense that numerous people turned to Pentecostalism not only for solutions to individual problems, but also for spiritual prescriptions for national economic and social woes (Adeboye 2003/2004, 136-159). However, it seemed that some African Pentecostal Churches also augmented their spiritual prescriptions for social and community prosperity with motivational seminars and other practical interventions meant to promote sustainable development. At what point did this occur and what circumstances made this additional effort necessary? Before we explore this with the case study of RCCG, let us now clarify the concept of sustainable development and how global perspectives on it intersect with Christian and local ideas on development.

\section{Sustainable development: global discourse, Christian thought and local perspectives}

The global discourse on sustainable development attracted significant attention after 1987 when the World Commission on Environment and Development $(1987,41)$ underscored its significance thus pushing it to the top of the agenda of the United Nations and of multilateral development banks. Its famous definition of sustainable development as 'the development that meets the needs of 
the present without compromising the ability of future generations to meet their own needs' has been endorsed, debated, criticised and challenged by various scholars and practitioners. This concept of sustainable development is seen as addressing the relationship between three major components, namely, the economy, environment and society. In today's world, these three are not usually placed on the same pedestal. Giddings et al. (2002, 187-196) argued that the economy more often than not gets more attention than the others because societal progress is often measured by its economic growth. Meanwhile, this has little to do with the quality of human life, nor with inequalities in various societies. The prevailing reality is that the economy is dependent on both society and the environment. Without society, there can be no economy.

Before the 1980s, global development discourse was focused on rapid industrialisation and measurements of economic growth. This, among other things, birthed the dichotomy between developed and underdeveloped countries. The resulting quantifications of development often overlooked important sociopolitical factors and deeply entrenched inequalities among various groups of people. The persistence of mass poverty and the need for environmental justice thus triggered the debate on sustainable development (Ajulu 2010, 163-166; Giddings et al. 2002, 187-196).

Some scholars have called for a rethinking of the concept of sustainable development, particularly in the interrelationship among its component units. Hardi and Zdau (1997, 194) contended that modern theories of sustainable development now emphasise the need to adopt a 'whole system' approach that takes note of emergent properties, complexity and interactions. Bob Giddings et al. (2002, 187-196) have recommended an integrated view of the concept. According to them, 'defining its aim as human well being would encourage seeing discrimination in any form as contrary to sustainable development, rather than as present, as undesirable but justified as gains elsewhere'. They further suggested that 'instead of having a priority on the economy, which is a means to an end, the focus [of sustainable development] should be on human provisioning and satisfying needs which may be done in many ways than those prescribed within economy' (Giddings et al. 2002, 187-196).

In all, sustainable development is now about a holistic and integrated way of looking at the world; concentrating on sustainable livelihoods and well-being and long-term environmental sustainability (Hopwood et al. 2005, 38-52). The idea is to give development a broad base and create room for moral and equity dimensions hitherto suppressed. In other words, development interventions are to 'wear a human face'.

Christian thought on development also emphasises the human factor. Central to it is the concept of stewardship, which emphasises responsibility and accountability. This perspective according to (Oladipo, 2000) 'decries the unbridled quest for economic gains where no one cares about who and what are being hurt in the process' (147). The biblical support for this is taken from Gen. 2:15 where God placed mankind in the Garden of Eden to work it and care for it. The church is the true steward and it is charged with 'responsibility by God 
through Jesus and is empowered by the Holy Spirit to effectively deliver holistic development for the transformation of individuals and their communities, by alleviating poverty and other social and environmental problems' (Ajulu 2010, 160). The end of development is to improve the total man: 'true development' is that which improves the total person in a holistic manner. This is summed up in shalom; meaning peace, completeness and well-being. Oladipo (2000,147) affirmed that such is the goal of development from the Christian perspective.

Scholars have pointed out the need for Christians to engage in development work (Bornstein 2002, 7; Brandt 1995, 260). Each man created in the 'image of God' is entitled to a decent and dignified living. While the church is to bring the good news to the poor (Lk.4:18-19) as was the mandate of Jesus Christ, the individual Christian is also expected to demonstrate his faith in good works. 'Hence, socio-economic development is an imperative sphere of engagement for the church' (Oladipo 2000, 147). Even for Christian NGOs where economic development is often a primary objective, development is still conceived in an overall manner i.e. of the whole person, the full human - material and spiritual. The theology of holistic development is thus deployed to address spiritual and material deprivations to enable a Christian to access abundant life.

Yoruba thought on development is here presented as an example of a local perspective on the subject. The Yoruba of Southwestern Nigeria conceive of development as ilosiwaju. This describes improvement of existing social conditions. Development is not conceived only in material terms as found in western theories; it incorporates all aspects of life in a holistic manner and also connects the past with the present and future. Central to this is the idea of the development of human character, which determines competence in the management of human affairs (Oluwole 1997, 139-150). This is the propeller that drives overall societal development. Individual character development is encapsulated in the local concept of omoluabi.

The omoluabi is an epitome of moral rectitude. Such an individual is dignified and guided by culturally approved standards of behaviour. To become an omoluabi, emphasis is laid on the cultivation of virtues such as patience, respect for others, teachability, self-control, hardwork, diligence. The moral import of being a person imbued with character is evident in the fact that personhood, within the Yoruba moral universe, is earned. This transformation, according to Afolayan $(2017,886)$, 'is a positive ontological progression, a moral maturation in time, from a mere individual, to a dignified omoluabi'. The traditional ideals that promote community development are thus derived from omoluabi traits.

It is important to point out here that the dualism of western thought, which tends to consider different aspects of life as being distinct does not apply to Yoruba thought, which conceives of life holistically. A similar claim has been made for other non-western cultures by Brian Woolnough. According to him, knowledge in such contexts inevitably includes both spiritual and physical dimensions. 'There is no need to bring together, to integrate different distinct components into a single whole: they already exist in holistic unity' (Woolnough 2011, 5). 


\section{Olufunke Adeboye}

It is thus clear from the above discussion that development is concerned with the holistic integration of different strands of human life. Moreover, the element of sustainability varies from one perspective to the other. In the global secular discourse, the emphasis is on renewable environmental resources, human livelihoods and economic growth. In Christian theology, sustainability consists in integrating God's ethical agenda into development prescriptions. In the African Yoruba worldview, sustainability relates to maintaining the centrality of human character cultivation at the heart of community development initiatives. Common to all approaches is a growing concern for human, and by extension, community well-being.

\section{The Redeemed Christian Church of God and CSR}

The RCCG was founded in 1952 by Josiah Akindayomi, formerly a prophet in the Cherubim and Seraphim Church (Adeboye 2003/2004, 23-56). Josiah had no formal education but after receiving the 'call' to ministry, it was widely believed that he demonstrated great powers of miracles and healing. For much of the period that he led the church (1952-1980), the membership was drawn mainly from the low-income class. This presupposes that various material needs were represented in the church. While reminiscences by early members emphasise acts of kindness among individuals, there are no indications of centrally organised interventions from the church to its immediate environment (Akindayomi 2010; Mulero 2012; Olateru 2007). The church was equally poor. Most of its history in this phase was taken up with hinterland preaching tours by the founder. The 1970s also saw the institution of another outreach programme called the 'Congress'. Many converts were won with accompanying 'testimonies' of miracles (Mulero 2012, 80-123). The only centrally planned social service of the church that touched others outside its walls was the operation of its maternity centres. These centres, located within bigger branches of the church, had no doctors or nurses but were manned by 'midwives' - the church's equivalent of traditional birth attendants, who were seen as invoking the power of prayers to deliver pregnant women safely. In the church narratives, one of the celebrated testimonies in the Headquarters Maternity Centre was that of a woman who had previously had three caesarean sections in government hospitals. After joining the RCCG at conversion, with her husband, her next pregnancy was safely delivered in the maternity through prayers without any need for surgical intervention. This experience encouraged her to have one more baby at the maternity. Her husband, Enoch Adejare Adeboye later ordained pastor in the church, succeeded Rev. Josiah Akindayomi as the General Overseer in 1981 (Odesola and Olubiyi 2017, 55).

Under the leadership of Pastor Adeboye, the RCCG made unprecedented expansion. Apart from widening its social base to attract middle-income members through its 'model' parishes, it also spread into different parts of the country and even beyond. From 31 parishes in 1980, it grew to 37,320 in 2017 within Nigeria (RCCG 2016, 5). Beyond the country, it has established its 
presence in 190 nations of the world. Its educational programmes started in 1981 on a very small scale with the establishment of its first elementary school within the premises of the headquarters church at Ebute-Metta in Lagos. Since then, the number of schools (both primary and secondary) owned by the church has grown to 258 (227 primary and 31 secondary schools).

The inability of government in the 1980s and 1990s to meet the growing need of the nation for social services created a vacuum for NGOs and churches such as the RCCG to fill. Within Nigeria, 'model' parishes were the arrowheads of the social work of the RCCG. Between 1991 when the model parishes were becoming consolidated and 2011, there were sporadic responses from various RCCG parishes to needs in their immediate locations. RCCG $(2016,5)$ reported that by 2011, the church took a first step towards harmonising its social intervention by creating the office of an Assistant Provincial Pastor in each of its 210 administrative provinces to oversee its social welfare interventions, now dubbed corporate social responsibility (CSR). Early in 2018, a second step was taken in the harmonisation project. The office of a Special Assistant to the General Overseer was created to coordinate the church's CSR activities nationwide.

The driving motivation behind the CSR moves of the RCCG has been articulated by its leaders in various ways. Adeboye $(2015,8)$ notes that:

People want to hear not just about what is going to happen to them when they get to heaven. They also want to see the blessings they can have while they are still here on earth.... If you want people to come to know Christ, then you must also be willing to assist them in every way possible to alleviate their suffering physically, to alleviate their suffering materially by empowering them and to alleviate their suffering spiritually by casting out demons and so on and so forth.

This means that the church is not only to respond to the spiritual needs (spiritual suffering) of people but should also take care of their physical and material needs. This is a strategy to get people 'to come to know Christ'. Perhaps, a more robust justification of the CSR moves of the RCCG is that provided by Pastor Idowu Iluyomade, the head of the church's CSR department and Special Assistant to the General Overseer. Iluyomade, a lawyer by training, is the pastor-in-charge of Region 20 (presently comprising 15 provinces and over 1,500 parishes), also known as the 'Apapa Family' of model parishes. Among other groups of model parishes, Apapa Family has been the most proactive, productive, resourceful and committed to social work. It, therefore, did not come as a surprise to other members of the RCCG when the leader of that unit was given the mandate to head and coordinate the church's overall CSR activities.

The first thing that Iluyomade did was to change the caption of RCCG social intervention from corporate social responsibility to Christian Social Responsibility. In a treatise entitled Christian Social Responsibility: A Matter of Life and Death?, Iluyomade (2018) distinguishes between the corporate orientation of 
the business world to social work and that of the Christian community. Business organisations are required by society to be ethical in their operations, not focusing mainly on profits but considering the immediate and long-term social and environmental needs of the community where they operate (Amaeshi et al. 2006). Christian communities, on the other hand, are required by God to be socially responsive. CSR is therefore defined as a 'faith-based obligation to meet societal needs through the demonstration of love that positively impacts communities and individuals' (Iluyomade 2018). Iluyomade cites various biblical injunctions to support his claims (Lev. 25:35; James 1:25; Matt. 22:36-40) but the defining passage for him is Matt. 25:31-46. Iluyomade's (2018) exegesis of the passage presents CSR as a 'matter of life and death':

If truly our end goal is to make it to heaven, a wise person will investigate what conditions must be fulfilled to be able to make it to heaven and possibly receive a reward. Jesus also gave us a pre-view of the final judgment day in Matthew 25:31-46, that on that day all nations will be gathered before God and His holy angels and God will separate the sheep on His right and the goats on His left, and He would use Christian Social Responsibility as the litmus test and parameter to judge them, not how big their church is or how many missions they have or how many people fell under their anointing but Christian Social Responsibility. We all have a responsibility to be our brother's keeper.... When we get to heaven, God would ask simple questions like: 'Did you feed the poor? Did you give the thirsty drink and shelter the stranger? Did you take care of the sick? Did you visit and take care of prisoners?' ... Surprisingly, all those that ignored these needs were cursed and sent to everlasting hell fire meant for the devil and his angels whilst those that heeded the call for Christian Social Responsibility where [sic] ushered into life eternal.

CSR is thus Christian love in action, systematically packaged by the church to reach out to society. It is also driven by the sheer need in contemporary times and ultimately becomes an evangelical tool.

It is important to add here that the concept of CSR came up in 1974 during the Lausanne Conference of the world evangelical community led by Billy Graham. At the end of the conference attended by 2,300 evangelical leaders from 150 countries, a Lausanne Covenant was produced, which made social concern a compulsory element in mission work. Under a heading they termed 'Christian Social Responsibility' they repented of their 'neglect of social responsibility and for having sometimes regarded evangelism and social concern as mutually exclusive'. They equally noted that 'evangelism and socio-political involvement are both part of Christian duty' (Woolnough 2011, 4). It is not clear whether Iluyomade read this conference report, but his CSR ideas correspond to the ideals of the Lausanne Covenant.

Iluyomade $(2018,23)$ also offers some clarification on the importance of 'sustainability' in CSR initiatives in the church. The secret for 'sustainable and 
improved CSR outcomes is by studying emerging trends and global best practices and putting structures in place to remain relevant and to achieve maximum impact'. He believes churches find it difficult to attract support from institutional partners for their CSR activities because they lack proper structures, transparency, and accountability. The way out is for faith-based CSR initiatives to comply with global best practices and institutionalise their interventions. These could be done by articulating a clear vision for CSR (i.e. long-term objectives); carrying out proper needs assessment that would inform CSR interventions; designing a strategy (policy) and institutionalising a corresponding structure that delivers the interventions. Other imperatives include innovation, documentation, publicity, impact assessment and quality assurance. All these would engender transparency, accountability, and acceptability of CSR by the larger society. These would make it relatively easy for the church to attract other corporate partners not only for direct funding but also for technical support for their projects. Ultimately, they would ensure sustainability in CSR outcomes.

To illustrate this, we now turn to the CSR activities of the 'Apapa Family', an administrative unit of the RCCG, which planted its mother parish at Apapa in Lagos. Of the 15 administrative 'provinces' under the unit, 13 are located in Lagos while two are in Ibadan. The 'family' also networks effectively with its diaspora chapters in other parts of Africa, and in Europe, North America, South America, Oceania and Asia. Its main CSR platform is the Excel Charity Foundation set up in 2008 and headed by a Chief Executive Officer with a board made of seasoned technocrats to ensure corporate governance. The eight areas of intervention identified by the Foundation are designated as: social, healthcare, education, media, business/economy, arts/culture/entertainment, government/politics, and sports (often called by the acronym SHEMBAGS in the church's terminology). To effectively execute related projects, the Apapa Family mobilises all its parishes (over 1,500) with the arrowhead being its headquarters parish called the City of David (CSR Chronicles 2018; Iluyomade 2018; RCCG 2018; RCCG Apapa Family 2018). Their activities are summarised below.

\section{Social}

- The street feeding programme 'A Can Can Make a Difference' (ACCMAD) started around 2008. About 60,000 people are fed weekly. Over $\$ 2.5$ billion (about $€ 6$ million) have been spent on this in five years.

- Since 2006, two rehabilitation centres have been successfully operated, Stepping Forth Halfway House (to rehabilitate substance abusers) and Virtuous Women Home (to rehabilitate former commercial sex workers).

- In the framework of prison ministry, they have installed solar-powered streetlights in the prison environment in Lagos, have refurbished and equipped the medical centre at Kirikiri (Federal) Maximum Security Prison, and donated generators, ambulances, pharmaceutical drugs to Agodi, Ikoyi, Badagry and Kirikiri Prisons. Moreover, they have equipped the learning 


\section{Olufunke Adeboye}

centres for inmates and enrolled 130 for the General Certificate of Education O-level exams in 2010.

- A charity shop was established in 2008, and rebranded in 2015 as 'It's New to Me'. The shop offers clothing, shoes, babywear, furniture, home accessories and appliances at affordable prices.

- Other social interventions include the donations of public toilets, boreholes, streetlights, refurbishing various police stations in Lagos and donating computers to the Lagos Police Command.

\section{Health}

- In 2010, Healing Stripes Diagnostic Centre and Pharmacy was set up. The renal centre with 10 dialysis machines, offers 30 free dialysis sessions monthly (total: 3,277). Others are highly subsidised (total: 7,433). The centre partners with medical institutions in the USA and India for kidney transplants (12 transplants done already). A cancer-screening centre was established in 2011, and by 2018 it had screened over 100,000 people free and had treated 20,000 at subsidised rates.

- RCCG Apapa family has equipped government hospitals such as Massey Clinic, Yaba, and donated dialysis machines to Gbagada General Hospital, Lagos. They refurbished and equipped the intensive care unit of the Lagos State University Teaching Hospital.

- $\quad$ RCCG Apapa family has partnered with Mercy Ship International Floating Hospital, which docked at Cotonou, Republic of Benin in 2009. Patients were taken there for treatment and critical surgical intervention.

- They acquired three mobile medical clinics (at the cost of $\$ 21$ million, or $€ 50,000$ each) for monthly medical outreaches to rural areas. Over 10,000 people have been treated so far.

\section{Education}

- $\quad$ RCCG Apapa family has established River Bank Nursery and Primary School (in addition to its existing 30 schools); and Hope Centre (a primary school) at Makoko.

- They equipped 500 public primary school libraries in Lagos State, while partnering with other churches to equip additional 250 schools.

- The provide scholarship opportunities for the youth, e.g. the so-called Wisdom Group Scholarship (from Secondary to University). Fifty-one students have benefited so far.

- Adult literacy programmes, summer volunteer programmes and youth empowerment programme are offered.

- They endowed four professorial chairs of mathematics (in honour of Pastor E. A. Adeboye) at the universities of Lagos, Ibadan, Ife and Nsukka (at $\$ 50$ million each, equalling about $€ 120,000$ ). 


\section{Media}

- The RCCG Apapa family sponsored the production of two soap operas (Heaven's Gate and Oasis) on terrestrial and satellite television stations.

\section{Business and economy}

- They established the City of David Business Networks to encourage and train entrepreneurs and the Excel City of David Cooperative Society.

\section{Arts, culture and entertainment}

- God's Children Great Talent, a talent competition described as a 'faithbased social development initiative with a vision to build a global brand using talents for God's glory' started in 2011. Season 7 was held in 2017. Over $\$ 300$ million (about $€ 712,000$ ) have been spent on this and more than 10,000 children registered.

- There is a leadership programme which runs parallel to the competition.

- The Incubator is an event place, which hosts corporate meetings, social gatherings, conferences and seminars. It maintains a green environment and has a no-smoking and no-alcohol rule within its premises.

\section{Governance and politics}

- RCCG Apapa family has been organising town-hall meetings to encourage Christians to participate in politics.

\section{Sports}

- A professional football club, City of David United, was founded in 2007. It is owned by the City of David Parish. It engages about 15,000 youth under the Club quarterly. The vision is to use football as a tool for social impact and regeneration.

- Football is used as a platform for youth development through the following programmes:

- Omodelig: a grass-roots football competition for young boys and girls between the age of 9 and 15 . Over 5,000 players have featured in the competition since 2009.

- League of Champions: comprises mini-tournaments and inspiring talk sessions. In nine years, there have been over 100 sessions in two centres in Lagos (Ajah and Surulere) with over 1,500 boys each week and 40,000 boys impacted annually through it.

- Ambassador's Cup: the Club Ambassador, Super Eagles and Reading FC Forward, Sone Aluko interacts with young players through football clinics, media interviews, seminars and a tournament. Over 500 players are impacted through this week-long event every year. 
- City of David Football Academy trains young footballers in five cadres: U10, U12, U14, U16 and U18. Creating opportunity for education and exposure for professional football locally and internationally.

- City of David United Soccer Camp offers intensive soccer training in partnership with foreign football clubs.

- City of David United Soccer School is designed for children aged 5-16. It offers classes every Saturday at two centres in Lagos plus additional 12 weeks of intensive coaching during summer holidays. Over 300 students enrol each year.

- Other activities include the schools' partnership programme; an international football partnership with English Premier League football clubs Bolton Wanderers FC and AFC Bournemouth to organise soccer camps in Lagos with over 70 young players each year, the City of David United Scholarship Scheme, players vocational training, girls football development and national team call-up.

- Two landmarks are particularly worth highlighting. In 2013, the male team won the Lagos FA Cup and represented Lagos State at the national federation cup. In 2015, the female team won the Lagos FA Cup.

\section{Challenges of promoting sustainable development}

African Pentecostal Churches face a number of challenges in their bid to promote sustainable development. First is the challenge of funding. From the example of the RCCG Apapa Family provided above, it is clear that many social problems are systemic and require the fixing of social infrastructure, which is often capital intensive - road repairs, hospital equipment, etc. Where do these funds come from? A lot of churches collect freewill donations for special projects. Where such is not enough, external help is usually sought from corporate donors who are often reluctant to assist churches with their CSR funds. This brings up the second challenge of lack of appreciation and or recognition for the social work done by Pentecostal Churches by the wider society. This is due to the lack of transparency, accountability and corporate governance of such churches. No regulatory agency audits church accounts and prospective donors are not sure of what will become of their funds. Thus, even where there are lofty social intervention schemes, they are starved of funds. However, the RCCG Apapa Family example has shown that when churches adopt global best practices in the packaging of their social intervention programmes, they are likely to attract corporate sponsorship. The Excel Charity Foundation has enjoyed at various times the support of top institutions in the Nigerian banking industry such as First Bank of Nigeria, Stanbic IBTC Bank, Access Bank; Telecommunications firms like MTN, food manufacturing giants like Cadbury Nigeria and Unilever; and even the Shell Oil exploration company donated $\$ 10$ million (c.€25,000) to its cancer-screening centre (Iluyomade 2018, 123). 
A critical element missing in the policy structure of RCCG's CSR is a commitment to social justice and social action. Jakonda (1996, 26-33) remarks that the approach would have targeted the roots of social problems and aimed at transforming prevailing socioeconomic and political systems that nurture injustice with a view to achieving sustainable development. This implies that the church has to be more preventive than curative in its approach to social issues. The history of the Nigerian Church as a whole shows that even in the face of past oppressive military regimes, mainline churches have been more vocal than their Pentecostal counterparts in calling for social justice and criticising unjust rulers. Catholic priests have often led popular protests against objectionable government policies. Pentecostal leaders, on the other hand, periodically mobilise their congregations to pray for the nation. The impression often created is that 'Pentecostals would rather seek to nurse and rehabilitate the victims of a predatory socio-political system than to directly challenge the oppressive structures of such a society' (Adeboye 2003/2004, 136-159). A notable Pentecostal exception has been Pastor Tunde Bakare of the Latter Rain Assembly in Lagos, who openly denounces social injustice during his television programmes. What will therefore become of the capital-intensive social interventions of the RCCG when the social environment continues to reinforce and perpetuate inequalities and politically induced oppression? After all, even the Bible enjoins advocacy for justice and peace (Micah 6:8).

There is also the challenge of partnership. Who do Pentecostal Churches involved in developmental projects partner with? Some prospective development partners may be interested in supporting particular social projects but may have other views with which Pentecostals do not agree. Woolnough (2011, 201) has described this as the challenge of 'unequal yoke'. This is what happens in a case where African Pentecostal Churches are not willing to receive aid or other support from international secular partners who campaign for tolerance and non-discrimination of people with unpopular sexual preferences. Such organisations may have ample funds available for development aid, but Pentecostals are wary of such an 'unequal yoke'. This also applies in cases where Pentecostal Churches are reluctant to receive assistance from local manufacturers of tobacco, alcohol, etc. even when those companies are interested in supporting particular social interventions.

Furthermore, too many of the social intervention projects are urban based. The example of the RCCG given above shows that very little attention is devoted to the rural areas. A way out of this could be for churches to network with other local development-focused bodies. A number of them are also faith-based and have acquired considerable experience on the field. To illustrate, Jakonda $(1996,31)$ pointed to the Christian Rural Development Association of Nigeria (sponsored by the Evangelical Churches from Northern Nigeria). Such collaboration would facilitate exchange of information, experience, resource and joint advocacy on issues of social justice and empowerment of poor communities. Development efforts yield more results if tackled from the grassroots. It must be truly comprehensive: not mostly urban-centred but well spread out to incorporate rural areas too. 


\section{Olufunke Adeboye}

Pentecostal Churches also face the moral danger of engineering their social work solely for evangelism. This presents a delicate situation in which the likelihood of discrimination in acts of service is high. Other moral concerns according to Miles and Villiers $(2010,151)$ include the making of what has been called 'rice Christians' (those who convert in order to access material assistance), and the potential of spiritual abuse of vulnerable people (especially children). While Christian NGOs are more susceptible to this challenge than churches whose holistic mandate already integrates the spiritual with the material, there is nonetheless a need for churches to be seen as nondiscriminatory and non-coercive in their social campaigns. This is particularly crucial given the power asymmetries that characterise relationship between the church and the poor to whom it ministers. Good development is to be balanced by a Christian understanding of people as created with dignity, in God's image, irrespective of their status in life.

Finally, there are a number of development possibilities yet to be fully explored by Pentecostal Churches. The most striking is in the area of the environment and renewable natural resources. Others include intervention in the area of food security. Pentecostal Churches should lead their congregations in the mass cultivation of food crops and assist with irrigation technology in arid areas. They could also support members' cooperative societies to market and even export their produce. Beyond this, scholars have also suggested that churches should mediate in community disputes, emphasise preventive healthcare, not just curative, advocate against gender marginalisation, and for purposes of accountability clearly distinguish between projects made to earn profit for running the church and those set up to serve people (Oladipo 2000, 148-150).

\section{Conclusion}

The church generally has a lot of features that position it effectively to deliver development projects. According to Oladipo (2000, 148-150), these include its non-partisan nature, rootedness in the community, stability, concern for the poor and deprived, and a strong tradition of altruism. But more importantly, modern Pentecostal Churches with transnational branches enjoy global institutional linkages, which they can exploit for resource transfers, trainings and technical aid (Adeboye 2005, 439-465). The RCCG, for instance, has branches in 190 nations of the world. In North America alone, it has over 900 parishes. These represent ample social and material capital from which it can draw to aid its social projects.

To foster greater appreciation of the holistic dimension in development traditions and allay the fears identified above, there is a need for deeper cooperation across secular and sacred divides. Mega Pentecostal Churches like the RCCG are now adopting global best practices in their social interventions. Sustainability to such churches consists in the erection of viable structures and policies as part of their overall developmental strategy. This situates them as 
legitimate actors within the global space of development work. It is thus clear that to effectively address the various deprivations that have kept indigent souls from shouting hallelujah, Pentecostals should not just rush to them with material provisions and the Bible, but also take time to effectively package such interventions. Properly institutionalised interventions by Pentecostals will go a long way to promote sustainable development.

\section{References}

Addo-Fenning, Robert. 2003. 'Christian Missions and Nation-Building in Ghana: A Historical Evaluation.' In Uniquely African? African Christian Identity from Cultural and Historical Perspectives, edited by James L. Cox, and Gerrie Ter Haar. Trenton: Africa World Press.

Adeboye, E. A. 2015. 'Why We Focus on Corporate Social Responsibility.' The Good Samaritan. A Publication of the CSR Department of the RCCG 1: 8.

Adeboye, Olufunke. 2003/2004. 'Pentecostal Challenges in Africa and Latin America: A Comparative Focus on Nigeria and Brazil.' Afrika Zamani 11 \& 12: 136-159.

Adeboye, Olufunke. 2005. 'Transnational Pentecostalism in Africa: The Redeemed Christian Church of God in Nigeria.' In Entreprises Religieuses Transnationales en Afrique de l'Ouest, edited by André Mary, René Otayek, and Laurent Fourchard. Ibadan: IFRA, and Paris: Karthala.

Adeboye, Olufunke.2007. “'Arrowhead” of Nigerian Pentecostalism: The Redeemed Christian Church of God, 1952-2005.' Pneuma 29: 23-56.

Afolayan, Adeshina. 2017. 'From the Cosmos to the Society: Worldview as/and Philosophy.' In Culture and Customs of the Yoruba, edited by Toyin Falola, and Akintunde Akinyemi. Austin: Pan African University Press.

Aiyegboyin, Deji, and S. Ademola Ishola. 1997. African Indigenous Churches: An Historical Perspective. Lagos: Greater Height Publication.

Aiyegboyin, Deji, and Asonzeh F. K. Ukah. 2002. 'Taxonomy of Churches in Nigeria: A Historical Perspective.' Orita: Ibadan Journal of Religious Studies 24, nos. 1 \& 2 (June and December 2002): 68-86.

Aiyegboyin, Deji. 2018. 'Resonance of African Initiated Churches' Beliefs and Practices in Nigerian Pentecostal Praxis.' In The Changing Faces of African Pentecostalism, edited by Babatunde A. Adedibu, and Benson Ohihon Igboin, 63-87. Akungba: Adekunle Ajasin University Press.

Ajulu, Deborah. 2010. 'Development as Holistic Mission.' In Holistic Mission: God's Plan for God's People, edited by Brian Woolnough, and Wonsuk Ma. Oxford: Regnum Books International.

Akindayomi, Josiah O. 2010. This Is My Story. Dallas: One Hour Books.

Amaeshi, Kenneth M., Bongo C. Adi, Chris Ogbechie, and Olufemi O. Amao. 2006. 'Corporate Social Responsibility in Nigeria: Western Mimicry or Indigenous Influences?' http://dx.doi.org/10.2139/ssrn.896500.

Anderson, Allan. 2001. African Reformation: African Initiated Christianity in the Twentieth Century. Trenton: Africa World Press.

Anyanwu, U. D. 2003. 'Educational Institutions and Christian Engagement with Societal Challenges.' In Uniquely African? African Christian Identity from Cultural and Historical Perspectives, edited by James L. Cox, and Gerrie Ter Haar. Trenton: Africa World Press. 


\section{Olufunke Adeboye}

Asamoah-Gyadu, J. Kwabena. 2007. 'Born of Water and the Spirit: Pentecostal Charismatic Christianity in Africa.' In African Christianity: An African Story, edited by Ogbu U. Kalu. Trenton: Africa World Press.

Barthel, Diane. 1985. 'Women's Educational Experience under Colonialism: Towards a Diachronic Model.' Signs 2, no. 1: 140.

Bornstein, Erica. 2001. 'The Verge of Good and Evil: Christian NGOs and Economic Development in Zimbabwe.' Political and Legal Anthropology Review 24, no. 1: 59-77.

Bornstein, Erica. 2002. 'Developing Faith: Theologies of Economic Development in Zimbabwe.' Journal of Religion in Africa 32, no. 1: 4-31.

Bourne, Richard. 2015. Nigeria: A New History of a Turbulent Century. London: Zed Books. Brandt, Donald. 1995. 'The Poor and the Lost: A Holistic View of Poverty.' Missiology 13, no. 3: 260-266.

Campbell, John. 2010. Nigeria: Dancing on the Brink. Ibadan: Bookcraft.

CMS Papers. 1877. University of Birmingham, UK. CA2/019. W. S. Allen, journal extract, 24 June 1877.

CMS Papers. 1879. University of Birmingham, UK. CA2/056. James Johnson, journal extract, 18 September 1879 .

CSR Chronicles, ed. 2018. CSR Chronicles: A Compendium of Christian Social Responsibility Interventions of the RCCG 1, no. 1.

Garlock, Ruthanne. 1981. Benson Idahosa: Fire in His Bones. Tulsa: Praise Books.

Giddings, Bob, Bill Hopwood, and Geoff O'Brien. 2002. 'Environment, Economy and Society: Fitting Them Together into Sustainable Development.' Sustainable Development 10: 187-196.

Hardi, Peter, and Terrence J. Zdan. 1997. Assessing Sustainable Development: Principles in Practice. Winnipeg: International Institute for Sustainable Development.

Hopwood, Bill, Mary Mellor, and Geoff O'Brien. 2005. 'Sustainable Development: Mapping Different Approaches.' Sustainable Development 13: 38-52.

Iluyomade, Idowu. 2018. Christian Social Responsibility: A Matter of Life and Death? Lagos: RCCG.

Jakonda, Sulaiman Z. 1996. 'The African Development Scene and the Church.' Transformation 13, no. 4: 26-33.

Jordan, J. D. 1949. Bishop Shanahan of Southern Nigeria. Dublin: Clonemore \& Reynolds.

Kalu, Ogbu U. 2008. African Pentecostalism: An Introduction. Oxford: Oxford University Press.

Maxwell, David. 1998. 'Delivered from the Spirit of Poverty? Pentecostalism, Prosperity and Modernity in Zimbabwe.' Journal of Religion in Africa 28, no. 3: 350.

McIntosh, Marjorie Keniston. 2009. Yoruba Women, Work, and Social Change. Bloomington: Indiana University Press.

Miles, Glenn and Villiers, Ian de. 2010. 'Christian NGOs and their Role in Holistic Mission.' In Holistic Mission: God's Plan for God's People, edited by Brian Woolnough, and Wonsuk Ma. Oxford: Regnum Books International.

Mulero, Z. A. 2012. My Life with Two Prophets. Ibadan: LTL Publications.

Odesola, J. F., and Olaitan Olubiyi. 2017. 'Courtship, Marriage and Home-Building.' In Pastor E. A. Adeboye: His Life and Calling, edited by Michael Omolewa, Johnson Odesola, Olaitan Olubiyi, and Akinjide Osuntokun. Ibadan: Bookcraft.

Oladipo, Julius. 2000. 'The Role of the Church in Poverty Alleviation in Africa.' Transformation 17, no. 4 (October/December): 147.

Olateru, Olanike. 2007. The Seed in the Ground: The Story of the Founding of the Redeemed Christian Church of God. Lagos: FOL. 
Olayiwola, David O. 1995. 'Joseph Ayo Babalola 1904-1959.' In Makers of the Church of Nigeria, edited by Joseph A. Omoyajowo. Lagos: CSS Books.

Oluwole, Sophie. 1997. 'The Labyrinth Concept of Time as Basis for Yoruba View of Development.' Studies in Intercultural Philosophy 8: 139-150.

Parsitau, Damaris Seleina, and Philomena Njeri Mwaura. 2010. 'God in the City: Pentecostalism as an Urban Phenomenon in Kenya'. Studia Historiae Ecclesiasticae 36, no. 2: 95-112.

Redeemed Christian Church of God (RCCG). 2016. Annual Report.

Redeemed Christian Church of God (RCCG). 2018. 'Christian Social Responsibility.' Policy Document.

Redeemed Christian Church of God (RCCG), Apapa Family. 'Lasting Change.' Programme Pamphlet for EXCEL 2018.

Woolnough, Brian E. 2011. 'Christian NGOs in Relief and Development: One of the Church's Arms for Holistic Mission.' Transformation 28, no. 3: 195-205.

World Commission on Environment. 1987. Our Common Future: Report of the World Commission on Environment and Development 41. 


\title{
8 Approaches to transformation and development
}

\author{
The case of the Redeemed Christian \\ Church of God, Nigeria
}

\author{
Babatunde A. Adedibu
}

\section{Introduction}

The proliferation of Pentecostal Churches across sub-Saharan Africa is described by Gifford $(2016,16)$ as 'perhaps the most salient social force in sub-Saharan Africa'. The changes within the Christian landscape are not only peculiar to Nigeria, but these churches have defied the forces of territorialisation and are perhaps one of the non-commodity exports from the African continent to North America, Europe and Asia. Indeed, African Pentecostalism is now globalised. Interestingly, the growth of Pentecostal Churches in Africa is taking place at a time when researchers are increasingly interested in the nexus between development and religion (Adedibu 2018, 1-9; Adogame 2016, 1-11; Bompani 2012, 307-330; Deneulin and Rakodi 2010, 45-46; Probasco 2016, 233-249; Schnable 2016, 216-232). While acknowledging the complex nature of those two mysterious phenomena as observed by Adogame $(2016,2)$, it behoves us to note that they are linked to one another. Religious institutions like the Redeemed Christian Church of God (RCCG) are one of several examples of African Pentecostalism that are thriving and actively involved in the personal transformation of their adherents and development of the Nigerian state. Until recently, social scientists have not considered religion as a factor to reckon with in modern development theories. According to Adogame (2013), development was primarily conceived as an economic growth model. However, Adogame $(2016,2)$ argues that 'it is expedient that scholars explore religion as development and development as religion; just as further problematising the concept of "development as religious discourse" and "religion as development discourse"'. This highlights the complexity of the nexus between religion and development. Adogame's perspective highlighted above further led to his advocacy of the concept of development from below which does not

foist definitions and concepts on religious peoples and institutions, it is imperative on scholars and development actors and agencies to auscultate how and to what extent religious actors and their institutions may define, critique, conceptualise and theologise development, human progress and 
flourishing not only through abstract, metaphysical and canonical expressions, but also in concrete, prosaic, lived experiences.

Development paves way for maximisation of human dignity, fulfilment, equity and quality of life through the appropriation of right choices devoid of social, economic and political discountinuties (Ellis and Ter Haar 2006, 351-367). Tarimo $(2005,12)$ affirms this perspective as he posits that:

Development must be (ought to be) understood regarding a liberation process in which the whole person and the entire community are involved. Such a basic definition calls us to approach development as an ongoing transformation of society which not only ensures that everybody has the necessities of life, but that the decision-making process in society is genuinely participatory. Development then, is a multidimensional revolution, economic, social and cultural, to release and mobilize the energies and potentialities of the people.

The above asserts that development is not synonymous only with the economic growth model. It is quite intriguing that in over 27 years of extensive research and publications by the United Nations Development Programme (UNDP) of Human Development Reports (HDRs), religion is yet to be considered a major factor in development. In the $2015 \mathrm{HDR}$, it was stated in the foreword by Clark (2015, iii) that:

Twenty-five years ago the first Human Development Report in 1990 began with a simple notion: that development is about enlarging people's choices - focusing broadly on the richness of human lives rather than narrowly on the richness of economies.

Applauding the founding objective of this annual publication by the UNDP and the production of over 700 reports which claim to give more opportunities for people to make more choices, has repeatedly failed to consider religion as a correlate of human development (Commission for Africa 2005, 127-129; Ellis and Ter Haar 2004, 352; Marshall and Keough 2004). As understandable as it might seem with religious fanaticism and terrorism on the upsurge, particularly in the West and Africa, many do not have a firm grasp of what religion entails. As such, the importance of religion in human development has been grossly understated. Interestingly, some international agencies are appropriating the role of religion in development such as the Department for International Development, World Bank and International Monetary Fund (Belshaw et al. 2001, 7-16). In the year 2000, the World Bank and Anglican provinces in Africa jointly organised a conference on the theme of religion and development, seeking ways to partner with the churches as agents of development in their contexts. Nevertheless, sceptics of religion claim it is synonymous with poverty, 


\section{Babatunde A. Adedibu}

as observed by Crabtree (2010). A typical argument to support the previous assertion is the fact that most nations where religion is thriving are either classified as underdeveloped or Third World countries due to low median per-capita income while secularised countries in the West where religion is domiciled in the private space have higher average per-capita income (Crabtree 2010). However, religion plays a functional role in development in sub-Saharan African and among Africans in diaspora in addressing their existential challenges and family life.

Given these emerging trends within development circles, Offutt et al. (2016, 207-215) have called on sociologists to explore the link between religion and development due to the changing pattern of funding challenges and the competitiveness among faith-based organisations and secular groups. Adogame $(2016,12)$ opines that most of the previous scholarships failed to consider the impact of colonialism and imperialism on the development of the African continent, leading to labels such as underdeveloped or developing nations or at best Third World economies. He further argues that despite the end of colonialism and imperialism the continent still suffers 'from the deleterious effects of Western Colonialism and neo-colonialism'. Adogame $(2016,4)$ berates the hegemony of the West for the economic subjugation, tyrannical as well as a bigoted disposition on the imposition of western knowledge that

collided with indigenous knowledge systems in a spate of bricolage of knowledge. The knowledge funnelled through the colonial process took centre stage, assuming a dominant epistemology that marginalized and almost silenced alternative worldviews and conceptualizations of the universe.

Despite the paucity of Adogame's assertion, he fails to acknowledge the postcolonial era of the financial and moral corruption of African leaders, and the continued exploitation of their states by being tied to the aprons of Swiss banks as the safe financial haven of their loot. However, Adogame $(2016,12)$ has berated the impact of the massive imperialistic notions by missionaries and colonialists as it heralded an era of superimposition of western ideals espoused through the lens of enlightenment that normalises a form of 'otherliness and binaries of differences adopted as tradition versus modernity, modernity, primitive versus civilised, superiority versus inferiority complex, developed versus undeveloped'. In light of the above assertions, Adogame $(2016,2)$ calls for a reappraisal of the western definition of development as he claims 'we need to re-interrogate and reinterpret the definitions of development from above against the backdrop of colonialism and the economics of unequal exchange'. Ellis and Ter Haar $(2006,362)$ have worked out a call for a paradigm shift on the definition of development through the religious lens with respect to developing countries:

if poor countries are to develop, it is not so much new policy instruments that are needed, but rather a new vision of what development means, and 
how it should be implemented. People's full range of resources should provide the foundation for any development strategy.

Ter Haar and Ellis further noted that a holistic perspective of development should include people's religious or spiritual resources, fiscal or material resources in the pursuit of tranquillity and safety, the value of governance, finance, health and education which are pivotal to development. The historical credibility of religious institutions and communal life in sub-Saharan Africa validates these institutions to be major development actors in their contexts (Frost et al. 2018; Öhlmann et al. 2016).

However, in Paul Gifford's (2016) recent volume Christianity, Development, and Modernity in Africa Gifford presents the role of African Pentecostalism in development in a different perspective. ${ }^{1}$ Gifford was apologetic in the opening pages of the book that criticism is expected as a matter of misconception or broad generalisations. Adedibu (2017, 94) noted that Gifford 'observed significance about Africa, Christian denominations, colonial emergence in Africa and the predatory disposition in the division of Africa' by the colonialists. However, from the front flap of the book, Adedibu (2017, 94) observed that:

Gifford set forth his views on observable theological and religious idiosyncrasies between African Christianity and historic denominations. The author describes the enchanted Christianity [and copiously] associates [it] with African Christianity and [describes] the disenchanted nature of historic denominations on human development.

Furthermore, Adedibu (2017, 94) identified Gifford's polemics on enchanted Christianity as he alluded to 'enchanted imagination, prosperity Gospel, and emphasis on the pastor's "anointing"', as defining characteristics of African Pentecostalism. Gifford's assertion is a misrepresentation of the hallmarks of African Pentecostalism.

Moreover, Gifford's perspective lacks contextual realities of the lived experiences of Africans negating the multifaceted nature of African Christianity and is trapped in broad oversimplifications of his assertion. Although it is expedient to appraise the role of Christianity and religion in sustainable development of Africa as posited by Gifford but to discountenance the contributions of religion to development in sub-Saharan Africa is wishful thinking. While Gifford applauds the role of religious organisations as development actors Adedibu $(2017,94)$ posits that

inadvertently [Gifford] seems trapped in essentialism as he [fails] to appreciate the heterogeneous and the uniqueness of African Christianities. Gifford's disposition implies the denial of the lived realities within the African context to address their existential realities as African Christianities, particularly [a] Pentecostal ethos which resonates in the traditional 
African [worldview] such as malevolent forces, curses, demons, witchcraft and exorcism.

The absurdity and flagrant denial of the spiritual realm raises further queries with respect to Gifford's claim of being well versed in the traditions of African Christianities. Although, Gifford's prescription of abandonment of enchanted Christianity which are major features of this Christian tradition, is a denial of the relevance of the theological and cultural sensibilities to Africans in Africa and diaspora as it addresses their existential realities. Adedibu (2017, 95) berated the isolationist orientation of Gifford's claim 'to condemn the Catholic Church, with its somewhat secularised development approach, of its insignificance for and ineffectiveness to offer an alternative solution to the enchanted religious needs of African Catholics is surprising'.

Furthermore, Gifford in this book failed to acknowledge that enchanted Christianity is a future of Charismatic Christianity which is fast becoming a major feature of Catholicism. The rabid claim to discountenance enchanted Christianity might suffice in a relativised society like the western world due to the effects of secularisation and enlightenment age but not in African Pentecostalism in Africa or the diaspora. Gifford's bloated perception of the contributions of the Catholic Church to the development of Africa is incomparable to other Christian traditions. The author's claim might have been correct during the colonial era in Africa (Adedibu 2017, 95), but in the last six decades, Pentecostal Churches have responded to some of the criticism of their tradition and have made an impressive impact on socioeconomic, political and educational initiatives in Africa and diaspora. It was quite evident that Gifford's treatise failed to critically examine the changing social, healthcare, economic and educational landscape of Africa which has the footprints of many Pentecostal Churches. Thus, African Christianity is redefining the concept of development from below and as such it is pertinent to interrogate the concept of development from below to demonstrate the contributions of religion using one of Africa's fastest-growing Pentecostal denominations as a case study. This work aims to contribute to the call for a paradigm shift by critically examining the role of RCCG in the transformation and development of Nigeria. My approach is at variance with normative economic growth models of development but within the remit of lived experiences of the Nigerian people. The import of such an approach is to defray scepticism about the contributions of religion to development from below as their 'narrative falls outside the radar of global, human development reports (HDRs) and indices' (Adogame 2016, 2). RCCG, Nigeria, is used as a case study.

\section{The RCCG's contributions to transformation and development of the Nigerian state}

RCCG is a Pentecostal Church that evolved in 1952 as an offshoot of an African Independent Church - Cherubim and Seraphim Church - started by the late Reverend Josiah Olufemi Akindayomi, who was unlettered, as a prayer 
band (Egbe Ogo-Oluwa (Glory of God)). Scholars in the mould of Adeboye $(2005,2007 b)$ and Bolarinwa (2005) have published the call and ministry of the founder of the denomination in Africa and the diaspora. Akindayomi led RCCG until his demise on 2 November 1980 at the age of 72 . He was noted for his ascetic and Puritan disposition to wealth and profound prophetic ministry. The demise of Akindayomi heralded a new phase in the history of the denomination as Enoch Adejare Adeboye was chosen by 'divine fiat' as the next general superintendent of the denomination on 21 January 1981. Previous scholarship has researched extensively the transformation of RCCG to a world missionary player by Adeboye (Adogame 2007; Burgess et al. 2010; Ukah 2008). The current transnational status of RCCG is one of several examples of the globalisation of African Pentecostalism from Africa characterised by its idiosyncrasies. The appointment of Adeboye as RCCG General Overseer and his commitment to religious creativity through various programmes have led to a shift in the founding disposition of the church from world-rejecting notions to worldaccommodating ones. The repositioning initiatives as posited by Adedibu (2016) and doctrinal changes initiated by Adeboye have endeared the denomination to the upwardly mobile professionals across the entire social strata of Nigerian society, Africa and the diaspora.

\section{RCCG and civic engagement}

Various scholars, since the 1990s, have chronicled the dynamics of civil engagement of Pentecostalism in various countries in the global South and in the diaspora about the Pentecostal tradition as observed by Freeman (2012), Miller and Yamamori (2007), Gifford (1998) and others. Civic engagement, in the context of this study, is synonymous to the approaches and methodologies through which Pentecostal Churches influence and contribute to the development of their communities. Various approaches are utilised by faith-based organisations including the Pentecostal tradition based on the contextual analysis of the prevailing socioeconomic and cultural challenges of their communities. A Pentecostal denomination like RCCG has tremendous influence within its membership and as an agent of social transformation on wider civic culture. RCCG has succeeded not only regarding its missionising aspirations, but also contributing to the development of various communities where these churches are situated. The public visibility of RCCG is not limited to Nigeria, but also found in the diaspora.

The participatory model of the RCCG might be classified as the salt and light of its community. Various civic engagements of the denomination to ameliorate the socioeconomic life of its members and diverse communities where parishes are situated are in operation. RCCG, in different cities in Nigeria, undertakes charitable activities. Such initiatives include promotion of microfinance banks, youth camps, poverty alleviation initiatives, empowerment programmes, healthcare delivery to the less privileged and contributions to their communities through a wide range of social, spiritual and empowerment 


\section{Babatunde A. Adedibu}

programmes as well as educational activities to minimise the effects of the nation's dysfunctional educational system. For instance, when the late President Musa Yar'Adua authorised the amnesty for militants of the Niger Delta on 25 June 2009, Redeemer's University, Ede, owned by the RCCG was actively involved in providing support, counselling, mentoring and resettlement of some members of the militant group into society.

Burgess (2011, 160), in his research on Nigerian Pentecostal Churches, argued that 'religion had re-emerged as a potent political force and dominant feature in the national and political culture'. On the international scene, on 21 June 2016:

the General Overseer of RCCG, Pastor Enoch Adeboye, paid a courtesy visit to the United Nations Secretary General, Mr Ban Ki-Moon, in order to explore opportunities provided in the UN system to leverage on the influence of the church and its leadership in facilitating interfaith harmony and peace, creating a conducive environment for action towards attainment of the Sustainable Development Goals (SDGs).

(OnoBello.com 2016)

Adeboye, in his meeting with Mr Ban Ki-Moon, also stated 'that the Redeemed Christian Church of God is focused on impacting the entire global community positively through the platform of its Christian faith and values'. It was emphasised that the church 'remains acutely aware of the need to go beyond business as usual to reach (and continue to engage) the youth population' (OnoBello.com 2016).

\section{Social capital}

The concept of social capital has been noted to be multifaceted as well as potentially ambiguous. The idea of social capital illustrates the significance and effects of social affability and 'connectedness and their relations to the individual and social structure' (Tzanakis 2013, 2). Social capital in different forms has come under the scrutiny of scholars like Durkheim, Marx, Weber and Tönnies as noted by Quibria (2003, 1). Coleman's (1988) and Putnam's (2000) 'definitions, each based on extensive empirical research, are among the most widely cited. A qualification added by [some] writers, including Putnam, is that the networks and norms are capable of being used for mutual or collective benefit' (Kilpatrick et al. 2003, 419). RCCG contributes significantly to community cohesion and development through the social capital of its members by being socially rooted and having shared values (Adedibu 2010, 199). Social capital has been identified by policymakers and politicians alike as a potential source of economic and social benefits due to its maximisation in civic engagement. Interestingly, RCCG parishes in Nigeria, through the shared vision of the denomination, have risen to the challenges within their host communities through their corporate social responsibility initiatives. The effectiveness of most social action is 
rooted in the in situ local knowledge of the church about its context in Nigeria as well as in the diaspora. RCCG provides elements of social capital through bonding, bridging and linking; it presents a formidable front to confront various factors that militate against development. The sacred spaces for worship in these churches do not only foster socialisation, rituals and religious practices, but also serve as social and business areas which provide bridge-building and linkbuilding among members. RCCG is thereby leading to a local and global flow of information and generation of interest and trust based on shared values.

I have previously observed that some scholars such as Bourdieu and Wacquant $(1992,119)$ have identified religious capital as part of social capital in faith-based organisations like RCCG and it 'is, therefore, the effects of religious and spiritual practices, beliefs, networks and institutions that have a measurable impact on individuals, communities, and societies'. Also, social capital refers to the various opportunities appropriated by a person such as influence, power and knowledge in a group. Likewise, spiritual capital has been appropriated by RCCG leadership largely through their authority, sway and dispositions in encouraging volunteering, philanthropy and social services. Significant numbers of volunteers are utilised during most programmes of the church, such as the Holy Ghost Congress. Volunteering enhances the bridging of social capital, creating links with people outside their immediate circles. Volunteering is an avenue for the development of 'a well-connected network that includes people from across a range of professions. Embedded in a well-connected network is workplace information which volunteers can use to help choose career paths, find work or find a new job' (Polidano et al. 2007, 4).

Asamoah-Gyadu $(2013,181)$ was quite succinct in his argument on the contributions of African Pentecostal Churches through human flourishing which he posited as the transformation of members of these faith communities into the likeness of Jesus Christ. The various testimonies of many adherents who were transformed as a result of their commitment to the Christian faith as well as its moral and religious codes inevitably leads to good citizenship and human development. At the RCCG 2016 Holy Ghost Congress, a young man, an undergraduate at one of the universities in the country, testified that he was a former cultist and engaged in occult practices but after he became born again, he was completely transformed. The impact of the aforementioned narrative is that apparent ethical personality is to be perceived by the civic community in respect of the born-again social life.

\section{RCCG as an agent of social transformation}

In light of the mission and vision statements of RCCG, its missionary ethos is evident. The religious creativity and innovations through the routinisation of charisma by Enoch Adeboye are synonymous with his aspiration to reach out to the unchurched. The multiplicities of programmes for virtually every social strata of society are reflective of the fact that RCCG is an agent of social transformation. Farinto $(2010,2)$ posits that: 


\section{Babatunde A. Adedibu}

the church in mission [as] an agent of change[s], indicates the spiritual impact of the presence of God in His creation. When a man first experiences the divine transformation of God, it is spiritual and physical, and then the human society, both the sacred and secular, feels its impact.

Farinto's assertion is not only prescriptive, but also revealing that the liturgical practices of RCCG, rituals and religious practices ultimately should produce citizens who intensely manifest purity and divine consciousness leading to reconciliation in relationships with God and men. The impact includes personal transformation and character development which is reflected in moral consciousness and good citizenship thereby leading to reduction of social ills as well as biblical standards as a yardstick for social, economic and public life. This is achieved through the evangelistic programmes like the Holy Ghost Services, Holy Ghost Congress, Campus Holy Ghost Service and Divine Encounter. The Campus Holy Ghost Services (CHGS) is the name given to the Holy Ghost Services that are conducted on the campuses of tertiary institutions in Nigeria. CHGS came into existence against the backdrop of increasing violence among campus gangs, popularly called campus secret cults (CSCs).

Ukah $(2003,231)$ noted that:

On 10 July, 1999, some students at the Obafemi Awolowo University (OAU), who professed to belong to a gang, murdered fellow students in cold blood. In one night, about seven students were killed and several injured. Following this event, students took laws into their hands, and in their uncontrolled attempts to extirpate CSCs from OAU, Ife-Ife, hunted down and killed some identified members of CSCs, increasing the number of those killed and adding to the flurry of lawlessness and violence. Before this period, CSCs' activities in different Nigerian universities had claimed the lives of no fewer than twenty-five students.... Consequently, Adeboye was consulted, mandated and mobilised by the [former] President of the Federal Republic of Nigeria, Olusegun Obasanjo, and some university administrators to help in the sanitisation of the social and moral life of students. According to the President Obasanjo as '[w] e were considering this problem (of students' cultism) and as I was looking for ways and means of dealing with it, I rubbed minds with Pastor Adeboye and he took the responsibility to go to the institutions of higher learning'.

RCCG provides a model for the contemporary Nigerian Church with respect to its holistic ministry approaches. Since its establishment, RCCG has 'engaged in missions as an agent of transformation in individuals, groups and corporate entities, in the sense of seeking positive change in the whole of human life, spiritually, materially and socially' (Agbiji 2012, 156). CHGS first took place at OAU, on 17 November, 1999. Ukah $(2003,231)$ stated that 
Two months after, it [CHGS] was hosted by the University of Ibadan on 14 January 2000; and the following month [sic] it was the turn of Lagos State University (LASU) to play host to the divine guest on 11 February 2001. The University of Ilorin, where Adeboye once taught, played host to the event on 11 October 2002.

The impact of this initiative has complemented various universities' stance on zero tolerance to student cultism as well as veritable opportunity for campus evangelism and recruitment of new members into the Redeemer's Christian Fellowship (RCF), which is the campus fellowship of RCCG.

\section{Responding to social and health challenges}

RCCG, over the years, has been actively involved in various social, health and educational initiatives to ameliorate not only the challenges of its members, but also complement existing healthcare delivery in Nigeria and the diaspora. Riding on the crest of holistic philosophy, RCCG is creatively involved in the rehabilitation of drug-ridden youth as well as resettlement initiatives for a broad range of women involved in sex trafficking repatriated from Europe to Nigeria. To present an integrated approach to human and community development, the denomination over the years has developed a network of collaborative partners through its transnational network of churches with faith-based organisations in the diaspora to address some of the cogent health challenges. RCCG established various para-church organisations to address these social and health concerns. In a previously published article (Akhazemea and Adedibu 2011), the author chronicled the contributions of RCCG to healthcare delivery in Nigeria which are explored in detail below.

One paramount concern in Nigeria, as in many other African countries, is the HIV/AIDS pandemic. Akhazemea and Adedibu $(2011,58)$ noted that RCCG's perspective on HIV/AIDS is receptive of medical approaches embraced preventative approaches to curb the spread of HIV/AIDS. This is antithetical to Tiendrebeogo and Buykx's (2005, 15-16), who argued that:

HIV/AIDS juxtapose the interwoven issues of religious doctrines, ethics, morality and the official positions of religious hierarchies' perspectives.... In many countries, HIV/AIDS strategies, such as condom promotion, faced tremendous obstacles from faith-based organizations.... Religious leaders often reach a deadlock with other stakeholders over condom use and mandatory testing before marriage. They may also have contributed to selfstigmatization which is common among followers who find themselves HIV positive.

Akhazemea and Adedibu $(2011,58)$ succinctly capture the positive appropriation of medical science as well as religious capital in ameliorating the challenges of Nigerians infected with HIV/AIDS and creating awareness of the 
associated health risks and social stigma of infection with HIV/AIDS. According to Adogame (2007), the Redeemed AIDS Programme Action Committee (RAPAC) is the para-church ministry of RCCG responsible for using multiple approaches including education, production of behavioural communication resources on HIV/AIDS, advocacy of moral restraint, creating awareness and offering medical assistants to members of the church and the larger communities. Due to the transnational status of RCCG, RAPAC collaborates with various non-governmental organisations and multilateral agencies across borders to meet its founding objectives. For instance, Akhazemea and Adedibu (2011, 58) noted that

RAPAC initiatives were given impetus in 2005 with the selection of the organisation as one of the agencies in Nigeria to implement the HIV/ Counselling and Testing (HCT) project as part of the Global HIV/AIDS (GHAIN) initiative in Lagos state, with the support of the United States Agency for International Development (USAID)/Family Health International.

\section{Campaign against Drug Abuse Ministry}

Substance abuse and its associated challenges is fast becoming a major social ill across the globe, Nigeria inclusive. Campaign against Drug Abuse Ministry (CADAM) is the social arm of the RCCG charged with addressing the challenge of substance abuse within and outside the church providing succour to those who are involved in the abuse of substances. Akhazemea and Adedibu (2011, 61) noted that, 'CADAM is a well-structured unit of the church that recognises the holistic care delivery to drug addicts and ex-drug addicts. The understanding is reflective of their integrative approach to the delivery of health and spiritual care to drug users.' CADAM makes use of holistic healthcare delivery for her clients including medical and religious approaches with varying level of success over the years. At the dedication of its new facilities on 4 October 2017, the then Lagos State Governor, Mr Akinwunmi Ambode stated that:

CADAM has, on its own, with it[s] own resources, picked up, fed, sheltered, treated and rehabilitated many people who have been addicted to drugs, and given them a new life. I am optimistic that many lives that had been compromised as a result of drug addiction will be redeemed, stabilised and given a new hope for a better and meaningful future.

(Flashnews.com.ng 2017)

Since its inception, CADAM has 'treated about 2000 people with $70 \%$ of them living drug free, independent and productive lives in various professions' (Folu Adeboye, quoted in Odesola 2017, 15). The case of Ilimezekhe Salvage, who was rehabilitated from substance abuse and eventually graduated from university 
(Adeboye 2007a, 37; Odesola 2017, 16) says much about what the denomination is doing through CADAM. Some of the rehabilitated drug users are well integrated into society and gainfully employed. For instance, Victor Edo, a former drug peddler stated that

I sold my blood just to satisfy my urge ... I was the kingpin of Ikeja Cocaine Triangle. The media beamed its search light aggressively on us in 1987 . The NDLEA [National Drug Law Enforcement Agency] eventually arrested me. My father and my relatives rejected me, but eventually I came to CADAM in 1998. Here I was healed. And today, I am an ordained Pastor.

(CSR Chronicles 2018, 13)

\section{RCCG educational approaches to development}

In the last three decades RCCG has succeeded in redefining herself as a forwardlooking and educationally minded church. The flourishing school movement of RCCG started from a humble beginning at Ebute Meta in 1981, where Folu and Enoch Adeboye pioneered the first primary school. This led to the formation of Christ Redeemers School Movement (CRSM) which is part of the Children and Teens Department of the RCCG under the leadership of Folu Adeboye as director and chairperson. The commencement of RCCG's educational agenda has been linked with the vision of Enoch Adeboye of looking forward to a future when an education including distinctive Christian philosophy from elementary education to tertiary institutions would be a reality. The first secondary school established by the CRSM was Christ Redeemer College, Sagamu, Ogun State which was dedicated on 1 October 1996. CRSM has registered its presence in almost all the communities where RCCG parishes are situated. In furtherance of the founding ideals of the school movement of RCCG, the denomination's university known as the Redeemer's University, Ede (RUN) which took off in 2005. In 2018, RCCGestablished Redeemer's College of Technology and Management was approved by the Nigeria's National Board for Technical Education. Apart from these institutions, RCCG established its foremost theological college, the Redeemed Christian Bible College in 1980 which is now an affiliate of the department of Christian Religious Studies, University of Ibadan, and Redeemer's University, Ede. The institution is saddled with the responsibility of training the ministerial manpower needs of RCCG. These institutions established by RCCG contribute significantly to human capacity and national development.

\section{Conclusion}

In this chapter, I have demonstrated the nexus between religion and development. The evolving new concepts of human and sustainable developments give the opportunity to re-examine the lived religious experiences using the RCCG, Nigeria, as a point of reference. RCCG makes use of a multifaceted approach which includes the use of socio and religious capital and the appropriation of the 
public space for various socioeconomic and community development initiatives. The use of a case study has enabled this work to explain the nexus between religion and development through a descriptive approach, by observation, and through an analysis of the contributions of RCCG to development in Nigeria.

\section{Note}

1 The following paragraphs largely follow the author's review of Gifford's (2016) book in African Studies Quarterly (Adedibu 2017).

\section{References}

Adeboye, Olofunke. 2005. 'Pentecostal Challenges in Africa, and Latin America: A Comparative Focus on Nigeria and Brazil.' Afrika Zamani 11 and 12 (2003/2004): 136-159.

Adeboye, Olofunke. 2007a. Dispensing Spiritual Capital: Faith-Based Response to the HIV/ AIDS Epidemic in Nigeria. Lagos: University of Lagos, Faculty of Arts.

Adeboye, Olofunke. 2007b. “"Arrowhead” of Nigerian Pentecostalism: The Redeemed Christian Church of God, 1952-2005.' Pneuma 29, no. 1: 24-58.

Adedibu, Babatunde. 2010. 'The Urban Explosion of Black Majority Churches: Their Origin, Growth, Distinctives and Contribution to British Christianity.' Doctoral thesis, North-West University, Potchefstroom.

Adedibu, Babatunde. 2016. 'Redemption Camp, Mowe, Ogun State, Nigeria: A Sacred Space of Religious Innovations and Creativity.' Journal of Religion and African Culture 4, no. 1: 6-21.

Adedibu, Babatunde. 2017. 'Paul Gifford. 2016. Christianity, Development, and Modernity in Africa. New York: Oxford University Press. 187 pp'. Book review. African Studies Quarterly 17, no. 2: 94-95.

Adedibu, Babatunde. 2018. 'The Changing Faces of African Independent Churches as Development Actors Across Borders.' HTS Teologiese Studies/Theological Studies 74, no. 1. https://doi.org/10.4102/hts.v74i1.4740.

Adogame, Afe. 2007. 'HIV/AIDS Support and African Pentecostalism: The Case of the Redeemed Christian Church of God (RCCG).' Journal of Health Psychology 12, no. 3: $475-484$.

Adogame, Afe. 2013. 'Reconfiguring the Global Religious Economy: The Role of African Pentecostalism.' In Spirit and Power: The Growth and Global Impact of Pentecostalism, edited by Donald E. Miller, Kimon H. Sargeant, and Richard Flory. Oxford: Oxford University Press.

Adogame, Afe. 2016. 'African Christianities and the Politics of Development from Below.' HTS Teologiese Studies/Theological Studies 72, no. 4.

Agbiji, Obaji Mbeh. 2012. 'Development-Oriented Church Leadership in Postmilitary Nigeria: A Sustainable Transformational Approach.' Doctoral dissertation, Stellenbosch University.

Akhazemea, Daniel, and Babatunde Adedibu. 2011. 'Global Missionary Player: The Redeemed Christian Church of God: Her Message of Human Development.' In Encounter Beyond Routine. Cultural Roots, Cultural Transition, Understanding of Faith and Cooperation in Development, edited by EMW (Evangelisches Missionswerk in Deutschland e.V.), 53-64. Hamburg: EMW. 
Asamoah-Gyadu, Kwabena. 2013. Contemporary Pentecostal Christianity, Interpretations from an African Context. Eugene, OR: Wipf and Stock Publishers.

Belshaw, Deryke, Robert Calderisi, and Chris Sugden, eds. 2001. Faith in Development: Partnership between the World Bank and the Churches of Africa. Washington, DC: World Bank and Oxford: Regnum Books International.

Bolarinwa, J. 2005. The Redeemed Christian Church of God: Beliefs and Practices. Lagos: Somerset Ventures.

Bompani, Barbara. 2012. 'Religion and Development from Below: Independent Christianity in South Africa.' Journal of Religion in Africa 40, no. 3: 307-330. http://dx.doi. org/10. 1163/157006610X525435.

Bourdieu, Pierre, and Loïc J. D. Wacquant. 1992. An Invitation to Reflective Sociology. Chicago: University of Chicago Press.

Burgess, Richard, Kim Knibbe, and Anna Quaas. 2010. 'Nigerian-Initiated Pentecostal Churches as a Social Force in Europe: The Case of the Redeemed Christian Church of God.' PentecoStudies 9, no. 1.

Burgess, Richard. 2011. 'Practical Christianity and Public Faith: Nigerian Pentecostal Contributions to Intercultural Theology.' In Intercultural Theology: Approaches and Themes, edited by Mark J. Cartledge, and David Cheetham. London: SCM Press.

Clark, Helen. 2015. 'Foreword' in: Human Development Report 2015. Work for Human Development. New York: United Nations Development Programme, iii-iv.

Commission for Africa. 2005. Our Common Interest: Report of the Commission for Africa. London: Penguin Books.

Coleman, James S. 1988. 'Social Capital in the Creation of Human Capital.' American Journal of Sociology 94: 95-120.

Crabtree, Steve. 2010. 'Religiosity Highest in World's Poorest Nations.' 31 August 2010. https://news.gallup.com/poll/142727/religiosity-highest-world-poorest-nations.aspx.

CSR Chronicles, The. 2018. The CSR Chronicles, August 2018. Lagos: Redeemed Christian Church of God.

Deneulin, Séverine, and Carole Rakodi. 2010. 'Revisiting Religion: Development Studies Thirty Years on.' World Development 39, no. 1: 45-54.

Ellis, Stephen, and Gerrie Ter Haar. 2004. Worlds of Power. Religious Thought and Political Practice in Africa. London: Hurst.

Farinto, A. O. 2010. 'Church in Mission: An Agent for Transformation.' Paper presented at the National Conference for Christian Leaders, Christian Association of Nigeria, Abuja.

Flashnews.com.ng. 2017. 'RCCG Opens Drug Abuse Rehabilitation Centre'. 4 October 2017. www.flashnews.com.ng/2017/10/04/rccg-opens-drug-abuse-rehabilitation-centre/.

Freeman, Dena, ed. 2012. Pentecostalism and Development: Churches, NGOs and Social Change in Africa. London: Palgrave Macmillan.

Frost, Marie-Luise, Philipp Öhlmann, and Wilhelm Gräb. 2018. 'Avoiding "White Elephants" - Fruitful Development Cooperation from the Perspective of African Initiated Churches in South Africa and Beyond.' In The Changing Faces of African Pentecostalism, edited by Babatunde Adedibu, and Benson Igboin, 103-118. Akungba-Akoko: Adekunle Ajasin University Press.

Gifford, Paul. 1998. African Christianity: Its Public Role. London: Hurst \& Co.

Gifford, Paul. 2016. Christianity, Development, and Modernity in Africa. New York: Oxford University Press.

Kilpatrick, Sue, John Field, and Ian Falk. 2003. 'Social Capital: An Analytical Tool for Exploring Lifelong Learning and Community Development.' British Educational Research Journal 29, no. 3: 417-432. 
Marshall, Katherine, and Lucy Keough. 2004. Mind, Heart, and Soul in the Fight Against Poverty. Washington, DC: World Bank.

Miller, Donald E., and Tetsunao Yamamori. 2007. Global Pentecostalism, The New Face of Christian Social Engagement. Berkeley: University of California Press.

Odesola, Johnson, ed. 2017. The Good Samaritan 1 (8). Lagos: Redeemed Christian Church of God, Lagos.

Offutt, Stephen, LiErin Probasco, and Brandon Vaidyanathan. 2016. 'Religion, Poverty and Development.' Journal for the Scientific Study of Religion 55, no. 2: 207-215. http:// dx.doi.org/10. 1111/jssr.12270.

Öhlmann, Philipp, Marie-Luise Frost, and Wilhelm Gräb. 2016. 'African Initiated Churches' potential as development actors.' HTS Teologiese Studies/Theological Studies 72, no. 4. a3825. http://dx.doi.org/10.4102/hts.v72i4.3825.

OnoBello.com. 2016. 'Pastor Enoch Adeboye Meets with UN Secretary General, Ban Ki-Moon.' 22 June, 2016. http://onobello.com/pastor-enoch-adeboye-meets-with-unsecretary-general-ban-ki-moon/.

Polidano, Cain, Mark Harris, and Xueyan Zhao. 2019. 'Volunteering for Work and Pleasure?' Department of Econometrics and Business Statistics, Monash University. https://melbourneinstitute.unimelb.edu.au/assets/documents/hilda-bibliography/ conference-papers-lectures/2007/Polidano_ESAM.pdf.

Probasco, LiErin. 2016. 'Prayer, Patronage, and Personal Agency in Nicaraguan Accounts of Receiving International Aid.' Journal for the Scientific Study of Religion 55, no. 2: 233-249. http://dx.doi.org/10.1111/jssr.12263.

Putnam, Robert D. 2000. Bowling Alone: The Collapse and Revival of American Community. New York: Simon \& Schuster.

Quibria, M.G. 2003. 'The Puzzle of Social Capital: A Critical Review.' ERD Working Paper no. 40, Asian Development Bank.

Schnable, Allison. 2016. 'What Religion Affords Grassroots NGOs: Frames, Networks, Modes of Action.' Journal for the Scientific Study of Religion 55, no. 2: 216-232. http:// dx.doi. org/10.1111/jssr.12272.

Tarimo, Aquiline. 2005. Applied Ethics and Africa's Social Reconstruction. Nairobi: Acton Publishers.

Tiendrebeogo, G., and M. Buykx. 2005. Faith-Based Organisations and HIV/AIDS Prevention and Impact Mitigation in Africa. Amsterdam: KIT Publishers.

Tzanakis, Michael. 2013. 'Social Capital in Bourdieu's, Coleman's and Putnam's Theory: Empirical Evidence and Emergent Measurement Issues.' Educate 13, no. 2: 2-23.

Ukah, Asonzeh. 2003. 'The Redeemed Christian Church of God (RCCG), Nigeria. Local Identities and Global Processes in African Pentecostalism.' Doctoral dissertation, Universität Bayreuth.

Ukah, Asonzeh. 2008. A New Paradigm of Pentecostal Power: A Study of the Redeemed Christian Church of God. New Jersey: Africa World Press. 


\title{
9 The role of Pentecostalism in sustainable development in Nigeria
}

\author{
Mobolaji Oyebisi Ajibade
}

\section{Introduction}

The role occupied by the Pentecostal Churches in Nigeria for development cannot be underestimated. ${ }^{1}$ Gaiya (2015) identifies two responses to social challenges by Charismatic Pentecostal Churches in Nigeria. One, he opines that churches taking a centripetal position are either socially passive or they collude with corrupt leaders and groups who undermine efforts towards political, social and human improvement; yet, in their engagement with society they offer spiritual solutions to myriad social and political problems. Two, he shows that churches taking a centrifugal approach try to confront political and social problems, but these churches are relatively few and located primarily in Lagos, although they are growing in influence. He concludes that charismatic Pentecostalism in Nigeria is shifting from strictly spiritual solutions for sociopolitical problems to an emphasis on meeting social needs in practical ways. Further to the observation of Gaiya above, in this work we observe the centrifugal aspect of Pentecostalism in Nigeria. This portends that our main concern is the role of Pentecostalism in sustainable development.

Certain works exist on the role of Pentecostalism in national development. For example, research has been carried out on a comparative analysis of social network in Yorùbá Culture and Nigerian Pentecostalism: Evidence from the Christ Way Church (CWC), Nigeria (Ajibade 2006); Christ Way Church and Politics of Cultural Identity (Ajibade 2010); A Study of Pentecostal Spirituality in Christian Home Video Films in Southwestern Nigeria (Ajibade 2013); the Role of Pentecostal Churches in Curbing Social Ills in Ife Central Local Government, Osun State (Ajibade 2014); and Filmic Construction of Pentecostal's Roles in Sustainable Democracy (Ajibade 2016). In these previous works, it is crystal clear that the roles of Pentecostal Churches in social networks and how Pentecostal spirituality is contributing to the well-being of their members cannot be underestimated. The current chapter, however, is in furtherance of research into the role of Pentecostal Churches in sustainable development in Nigeria, mainly in the south-west.

The methodology adopted is the historical survey research design and descriptive analytical approach employing oral interviews and questionnaires as 
tools for eliciting information. Specifically, the study involved the triangulation process, which consists of the field investigative method, interviews and content analysis. Oral interviews were conducted with nine purposively selected church leaders, three each from Redeemed Christian Church of God (RCCG), Ile-Ife; Winners Chapel, Ile-Ife and Christ Way Ministries International, Ile-Ife between 2016 and 2017. The RCCG was chosen to represent another brand of African Pentecostal Churches that stemmed from the Aladura movement. The Winners' Chapel (also known as Living Faith Church) represents another brand of Pentecostalism in Nigeria with prosperity and healing as their main emphasis. This church represents the urban Pentecostal Churches in south-western Nigeria. In other words, they represent urban-driven and rural-driven Pentecostal Churches. Christ Way Ministries International was chosen due to its ruraldriven attributes as a Pentecostal movement. In addition, questionnaires were administered to 45 members, 15 from each church. The research questions focus on information concerning Pentecostal's roles in sustainable development, the roles of the church leaders in sociopolitical matters, socioeconomic issues and on family and marriage issues that are topical in sustainable development of the society.

\section{Pentecostalism and the gospel of prosperity}

Truly, money is indispensable and vitally important for organic existence entailing the growth process. There is even a witty saying that, 'God made man, man made money, money made man'. That is an age-long saying that articulates the negative influence of crass materialism on the sublime values of humanity. Significantly, this saying holds true in the secular world as it does in the religious community comprised by churches, mosques, temples and shrines among others, where values would ordinarily be expected to be dominantly influenced spiritually. Critics have argued that the modern wave of Pentecostalism in Nigeria is so grossly materialistic in form and content that only a very thin line of distinction is left between churches and business enterprises (Corten and Marshall-Fratani 2001; Ukah 2006).

These new-wave Pentecostals put forward the idea that God wants believers to get rich. They preach, in essence, a gospel of Christian consumer capitalism. For the common worshipper, the promise of financial prosperity through a direct relationship with Jesus is a major pull factor, while membership of a church opens access to social and business networks within the church community. Hope of wealth and of positive change is what Pentecostal and Charismatic Churches offer their followers. In many instances, the Pentecostals make references to John the Apostle, who wrote, 'Beloved, I pray that you may prosper in all things and be in health, just as your souls prosper' (3 John: 2 ) and 'the Lord takes pleasure in the prosperity of his servant' (Psalm 35:27). They maintain that poverty-stricken people are not good ambassadors of the gospel. This kind of teaching shapes and transforms the philosophy and mentality of the congregants and the struggle to make the teachings work in their lives. Martin 
Lindhardt $(2010,258)$ opines that the Pentecostals have specialised in a preaching style that 'contributes to the production of a sophisticated, successful, urbanist image with a cosmopolitan fervor'. Nigerian Pentecostalism is a dynamic movement, with subtle changes of emphasis, beliefs and strategies. Within the modern Nigerian Pentecostal movement, there is an ongoing broadening of emphasis - from just saving souls to saving the society; from signs and wonders in the church, to service and influence in the society (McCain 2013, 160). Most of their teachings are appealing to the masses, especially those who have been battered by poor economy and bad governance. The churches have embraced secular values although they express them in religious language. They have succeeded in incorporating essentially secular elements, giving them a religious garb (Togarasei 2015, 65). Their impact on preaching morality cannot be underestimated either; Miller and Yamamori $(2007,33)$ posit that the 'incremental impact on people's social welfare' due to the social uplift associated with Pentecostalism's moral prescriptions against alcohol, gambling and womanising gives them a 'competitive economic advantage over their neighbours'.

In other words, the perception of Pentecostals in Africa about prosperity is that prosperity comprises spiritual, mental and physical areas of life. The underlying principle of their teachings and practices in regard to prosperity is that God will reward faithful Christians with good health, financial success and material wealth 'according to his glorious riches in Christ Jesus' (Philippians 4:19). Although some scholars opine that teachings of prosperity among the African Pentecostals take its root from America, Ojo $(1995,106)$ holds an opposing view that, 'the prosperity message is original to African Pentecostal churches'. The message of prosperity among the African Pentecostals also reflects their belief that the 'blessings of Abraham' have been willed to believers as beneficiaries of the new covenant through their acceptance of Christ Jesus as their Lord and Saviour (Galatians 3). The 'blessing of Abraham' is thus interpreted by the Pentecostals to include success in life's endeavours such as social, economic, political, religious and physical well-being. Corten and MarshallFratani $(2001,1)$ say, "believers no longer retreat among themselves in order to maintain the purity of their beliefs and their moral rigor. Their understanding of salvation is highly existential focusing on God's ability to deliver the believer from material things of this life'. This shapes the mentality of their members and eventually spurs them into actions of taking steps that will improve their condition of living.

The gospel of prosperity is believed to offer a doctrine of morally controlled materialism, in which personal wealth and success is interpreted as the evidence of God's blessing on those who lead a 'true' life in Christ. Many Pentecostals believe that prosperity gospel is probably an answer to the situation. The prosperity preachers believed that poverty is a sign of sickness that must be wiped out of the society. The vogue in the teachings of the majority of these churches is based on prosperity teaching. Positive confession is encouraged and sowing of seed of faith is the hallmark of such churches. Besides teaching of faith on prosperity, there are many programmes organised by many among the Pentecostals 


\section{Mobolaji Oyebisi Ajibade}

to educate their followers on how to make money. Workshops are organised where certain handiworks are taught to the applicants. This is very common in Living Faith Ministries, the RCCG, Deeper Christian Life Ministries, Christ Way Ministries International among others. These could be regarded as capacity building and empowerment programmes.

It must be pointed out, however, that another characteristic of the new Pentecostalism is the advent of truly anointed clergymen and women, who opted for flamboyant lifestyles to prove the point of the compatibility of godliness and prosperity. It is not that such lifestyles detracted from the divine unction and authenticity of God's calling upon their lives. Such revered spiritual leaders proved the point of compatibility with their lives and ministry. Late Archbishop Benson Idahosa, founder of the Church of God Mission International headquarters in Benin, Edo State, was an example of such a leader. It has even been remarked that the late clergyman was widely reputed as having been among the greatest proponents of the holiness doctrine and fiery evangelism of the world. Nevertheless, he was so materially endowed that his complete worth each time he stood to minister was estimated to be among the choicest and costliest that money could buy. It is indeed on record that he literally redefined pastoral ministry in Nigeria by breaking new grounds of service and rewards, including pioneering private Christian university ownership. As a mark of divine unction upon his life, his ministry was accompanied with miracles, signs and wonders. His ministry happened to be an example of Pentecostal Churches that has positively affected the masses.

Besides Idahosa, the majority of Pentecostal Churches in Nigeria today are investing in education. Many Pentecostal Churches have nurseries, primary and secondary schools and private universities. Although the idea is being criticised as too expensive and beyond the reach of the common man, even for the members of the churches who own these schools, these institutions no doubt have given many Nigerian applicants the opportunity of accomplishing their life dream of attending university in Nigeria. Also, many Nigerians are provided desired education and employment opportunities through these institutions. It is observed that there is an uninterrupted academic calendar in such schools as we have with most of the federal and state-owned universities. Christian moral principles are emphasised in these schools as well. The manpower being provided contributes in no small way to the nation's sustainable development in the political, social, religious and economic spheres (Omotoye 2010). As earlier said, education is one of the pillars and thrusts of sustainable development in any nation; then this is a commendable act on the part of Pentecostal movements in the nation.

Many of the Pentecostal Church founders are the 'alpha and omega' of such churches. They are worshipped like gods with bodyguards and are difficult to be seen by the members of the church. Following the radically laissez-faire stance that the new Pentecostal movement has assumed, there has been an obvious shift of the doctrinal emphasis from 'holy living' to earthly mastery of the prosperity gospel. Most programmes by many Pentecostal Churches and messages from their pulpits are now designed to teach the prosperity principle, without as 
much as teaching the stewardship principle by which prosperity can be channelled strictly to divinely ordained purposes. In this regard, it is difficult to exempt any type of Pentecostal or Charismatic Church, especially in this milieu. This, however, appears to have bred fortune hunters in the church, whose spiritual goal terminates at applying the prosperity doctrine to make their millions, without much concern for how to make heaven (that is, eternal rest that is assumed to be in a place called heaven or paradise) while making the millions. In effect, critics insist, much of the rat races in the secular world have rubbed off on the church. Indeed, if a census were to be taken, perhaps as high as three quarters of the programmes and messages in most of the new-wave churches are inspirational and material prosperity oriented (Ukah 2006). The prevailing culture of affluence seems to be putting some church members under pressure to also meet certain standards of wealth. This could be regarded as a negative influence of Pentecostals' praxis among the people. Benjamin and Nkechinyere $(2014,319)$ maintain that the pursuit of material prosperity appears to be the greatest factor that contributes to the promotion of Pentecostalism today, especially in Nigeria. Many who throng to Pentecostal Churches are people looking for prosperity, and being conscious of this fact, many of their ministers have turned prosperity preachers.

It must also be pointed out that unbridled emphasis on miracle ministrations is to the detriment of discipleship orientation of the adherents. The consequence of this is that many professing born-again Christians are in reality not disciples in the Christian lifestyle but are merely sign-seekers with ephemeral commitment to the faith they profess (Omotoye Williams 2010). However, this is not to deny the fact that faith healings and signs and wonders have their own space in sustainable development, most especially in a country where the political leaders including the president and his cabinet members go abroad for treatment of their illnesses - because they can afford it with government money. The beggar of the poor populace might not have a choice other than resigning to faith healing. Consequentially, we can assert that Pentecostals occupy an indelible space in giving hope to the hopeless in the society. This was even attested to by John Magbadelo $(2004,15)$, who wrote that:

The expansion of the reach of Pentecostalism was facilitated by the economic and political crises of the 1980s, which naturally and psychologically created adherents who were drawn from the pool of frustrated and marginalised people in the larger Nigerian society. The claim to 'power' by Pentecostal outreaches across the country was attested to by the numerous reports of instant miracles and wonder turnarounds experienced by several attendees, devotees and testifiers.

Miller and Yamamori $(2007,33)$ posit that the 'incremental impact on people's social welfare' due to the social uplift associated with Pentecostalism's moral prescriptions against alcohol, gambling and womanising gives them a 'competitive economic advantage over their neighbours'. 
In addition, many of the Pentecostal Churches in Nigeria built their own hospitals and clinics where they not only attend to their members but to other patients who seek healing. Providing health therapies to the people is one of the roles of the Pentecostals in sustainable development in the nation. Many Pentecostal Churches such as RCCG, the Living Faith (aka Winner Chapel), Deeper Christian Life Bible Church and many more provide employment opportunities to people through the establishment of banks, printing presses and lots more (Omotoye Williams 2010).

\section{Pentecostalism, marriage and family issues}

To Pentecostal Christians, social questions are essentially spiritual issues. The thriving story of Pentecostal Churches confirms their attitude to the institution of marriage and family issues.

It is the contention of the Pentecostal Christians that the curses on the land can be combated and removed only by fervent charismatic prayers, worship and exorcism, usually led by a faithful pastor. Pentecostals argue that all current problems stem from what they call demonic practices; anyone who has participated in traditional rituals is seen as someone who has been contaminated by demons and needs deliverance as depicted in many of the Christian home videos. Through their teachings, the Pentecostals teach that happy marriage is possible, and that divorce is not a good thing to do. It has been observed that the majority of the Pentecostal Churches we studied in southwestern Nigeria take the issue of blissful marriage as a serious matter. For example, Christ Way Ministries International, which has its headquarters in Ile-Ife, has designated every third Sunday as a family Sunday. In all their churches, on this third Sunday, the sermon and Bible studies must focus on family issues. They allow contributions from members of the congregation. It is like a workshop where the pastor or the invited pastor will just give a short message on a particular area relating to family. After the sermon, the members will have the opportunity to contribute to the debate. This has been the practice in this ministry for more than a decade. They usually have testimony along this line that most of them have stable and happy families. This is one of the factors that attract people who want a happy home to join this church.

The Pentecostals view marriage as a social and spiritual phenomenon. This is in tandem with David Maxwell's studies of Pentecostal Churches in Zimbabwe in the book entitled African Gifts of the Spirit (2006). Maxwell discusses ways in which Pentecostal movements influence husbands to be oriented to improving the lives of their wives and children and thereby uplifting their lives and the society at large in the process. The Pentecostals see marriage as a spiritual matter as well and they preach deliverance from the power of sin, forgiveness and restitution among others, which are considered as hindrances to a happy and stable family.

The Pentecostals maintain in their teachings that the ideal matrimonial love between man and woman is realised in monogamy and they equally sermonise against divorce. It has been duly observed that based on their teachings on 
marriage many Pentecostals have more stable families and homes than the nonmembers (Ajibade 2006, 2010 and 2013). In Nigeria, especially among the Yorùbá of the south-west, the issue of childbearing is taken seriously while everything is done to oppose barrenness. Importance placed on childbearing in many instances is one of what make Pentecostals attractive to women especially those who are looking to God for childbearing. Belief and faith in God's word that, 'With God nothing shall be impossible' (Luke 1:37) is helping many women to rely on God for provision of children for them. However, many critics of Pentecostal Churches opine that it is a trick. In fact, these critics maintain that one of the most attractive marketing tricks being employed by Pentecostal Churches nowadays is a promise of children to the barren. They opine that Pentecostals are taking advantage of the gullible state of the barren using posters, radio and TV to target this group of people. Many observers accuse the Pentecostal Churches of playing on the desperation of the women to lure them into the church. On the other hand, there are many women who have testified and are still testifying that they have received miracle babies.

\section{Pentecostalism and sociopolitical criticism}

As African Pentecostalism grows in popularity, a critical engagement with its social and political consequences is unavoidable. In Nigeria, Pentecostals are beginning to participate actively in civil society, embracing forms of political participation and social action they had formerly rejected. The activity of Pentecostals in social and political issues in the nation is becoming more apparent at the moment. They are involved in prayers for the nation and all sorts of political debates in diverse forms. This is concomitant with Ayuk $(2002,197)$ that

The Pentecostals are vigorously involved with the political life of Nigeria. They pray for the country and are involved in some government activities. Their preaching is not devoid of political innuendoes and a call for appropriate actions to be taken... Nigerians generally believe that it is God that has intervened in the changes that have taken place in the country politically. They think that God has answered their prayers. God has therefore acted in a political situation.

The rapid multiplication of new religious groups with charismatic tendencies cannot be explained merely by a favourable social environment. The Pentecostal groups also generate social change, albeit indirectly, exerting their influence from within the social structure and the political ideologies. Currently, the Christian Association of Nigeria, which is the overall umbrella for all Christians in Nigeria, is clamouring for the restructuring of Nigeria. It was reported by Friday Olokor (2018) that:

A coalition of elderly Christians under the aegis of the Christian Social Movement of Nigeria has said that towards moving Nigeria forward from its 
stagnant position, the restructuring of the country should be the major focus of the 2019 elections. The conference insisted that the foundation of Nigeria needed redressing in the form of a restructuring of the country, which should be a major agenda of the 2019 elections.

In contemporary Nigeria, Pentecostals have achieved a new level of maturity based on their activities and preaching on civil rights, political and social engagements. Increasingly, they desire to become the subjects of their own history and are casting their lot with the new forces that are emerging in the societies. Whenever social chaos reigns, there is room for religious explosions of the Pentecostal group. Their religious principles have a direct effect on poverty and economic behaviour, and they lend religious and ideological legitimacy to new motivations, activities and institutions. It is obvious in the Nigerian society that the Pentecostals are sensitising their members to the need to be politically aware in order to be well positioned to influence the way things are done in national politics and governance. This goes beyond the former regular practice of praying for the government. Likewise, the establishment of the Justice, Peace and Development Commission (JDPC) and National Christians Elders Forum (NCEF) for instance was one way the church thought it could mobilise its membership to play a more assertive role in the way the people are governed. They encourage and support their members to take active roles in polity at all levels. Members are encouraged to register in parties and to also enrol for voting by obtaining voters' cards.

It is not in doubt, therefore, that there has been tremendous improvement in the quality of governance the people get since the JDPC was established. At least, the politicians are conscious of the enormous powers the church wields. From my observation, it is cheering to note that in the past 15 years, the church has been in the vanguard of the agitation for the establishment of good governance, rule of law, constitutionality, social justice and equality in the country. For example, at the end of the National Christian Elders Forum of 18 June 2018 the following were the resolutions of the Body:

a Christians must speak with one voice and have one common agenda for 2019 Elections and subsequent years.

b The Church should agree on Christian Political Leadership. A body should be recognized to provide direction and harmonize all the various Christian resources into one formidable asset for Christianity to pursue the entrenchment of Democracy as the indisputable National Ideology of Nigeria. This body shall coordinate screening political parties as well as Christian political candidates. Without proper Christian Political Leadership, harmonization and coordination would be impossible. A house that is divided cannot stand.

c Promote the doctrines of Truth, Righteousness and Repentance in all Christian assemblies because 'righteousness exalts a nation but sin is a reproach to any people'. 
d The Church should be in vanguard of demand for a New Constitution to replace the one in use that has Sharia inclined military decrees grafted into it. There is need for proper understanding of the nature of Sharia by non-Islamist Nigerians in order to keep Nigeria Sharia free.

e Discard Sharia compliant Finance and Banking Acts (this includes Islamic Banking and SUKKUK).

f The Church should also demand the establishment a Truth and Reconciliation Commission as the basis for healing, reconciliation and forgiveness in the country.

g Establish a Law Review Commission to isolate Sharia in our statute books.

Supports CAN Trust Fund to mobilize critical funding to make Christianity in Nigeria financially independent.

(NCEF 2018)

The above came up as a result of the feelings of Christians that they are seriously marginalised in Nigeria.

Also, the setting up of the Christian Association of Nigeria (CAN) was borne out of exigency, geared towards protecting the integrity of the Christian religion in the nation's complex sociopolitical life. The Pentecostals strive to act as the conscience of the nation by watching over the politicians who have manipulated the gullibility of the electorates for their own self-aggrandisement. The church is embarking and fighting for the emergence of a more just and equitable society, where corruption will be banished, human rights promoted and peace and tranquillity well established.

The Pentecostals are even agitating that some of their members should take up political appointments to avoid being governed by corrupt politicians who have no good intentions and plan for the nation. Due to the Christians' view of being marginalised they are even regarded as the most critical of government policies and ideologies that are regarded as inimical to their existence in the nation (Olokor 2018). It is not only Christian groups that are rising up against different forms of social injustice in Nigeria; the overwhelming upsurge of militant and resistant groups in Nigeria these days such as the Niger Delta Militancy, OPC, Bakassi vigilantes, the Boko Haram episode and other similar movements are commonly interpreted as demonstrations against the state resulting from the strains of injustice in the system and as signalling the level of discontent among the citizenry (Uchegbue 2013, 142).

In order to participate actively in governance and embark on the process of sociopolitical and economic liberation for the realisation of justice, the church is expected to be seen as both a religious and viable social institution. Christians are to take positive actions to destroy all forms of oppressions and injustice wherever they are found (Hastings 1976, 91). But this is not to say that the church as a body should be expected to leave the word of God to serve tables by getting itself involved in a violent revolutionary overthrowing of 
governments or even in partisan political activism. The liberating role of the church should be such that will enhance its influence on the sociopolitical and economic order without jeopardising its more spiritual and evangelistic vision and mission. This will involve it confronting and challenging every unjust, oppressive and exploitative structure with Christian values and ideals (Uchegbue 2013, 149). However, this must be done without involving violence and violation of fundamental human rights.

\section{Sharing and caring in Pentecostalism}

In many Pentecostal Churches where there exists a social network, whenever any member is in a terrible social and economic mess, his/her Pentecostal group becomes his/her succour. They will not only give financial assistance to the person but will also organise intercessory prayers to support the family. This is a way of showing that when the political authority fails in any given state like that of Nigeria, the Pentecostal groups identify with their group members. Christian ethics also go a long way in helping Christians to cultivate sustainable lifestyles. This is in tandem with the Yorùbá indigenous social networking of caring for the needy in various dimensions.

Many Pentecostal Churches have established philanthropic organisations to help widows, the fatherless, orphans and the less-privileged people in the community. It is the contention of the Pentecostals that they should get involved in the social and political issues in their various communities and that they should choose to become active players in civil society and politics. It is within the civil society - that is, participating at the grass roots - that Pentecostalism will make a key contribution to deciding the prospect of the nation's social system not only through their teachings but also through their involvement in the welfare of their members. In other words, active involvement in the newly emerging civil society is a historic opportunity that must not be wasted. The transforming power of Pentecostalism resides not only in the coherence of its doctrine, but in its flexibility and its capacity to give expression to new social practices in the defining moments of a society in transition.

This practice and ideas of institutionalised giving by establishing a common purse for money and material things to be given to those that are in need is supported by the life of the early Christians (Acts, 2:44-46) where it was said:

All the believers were together and had everything in common. Selling their possessions and goods, they gave to anyone as he had need.... They broke bread in their homes and ate together with glad and sincere hearts.

For example, a committee of five is usually chosen to control the 'basket' in many Christ Way Churches. Any member of the church who is in need could approach any of the members of the committee. When the need of a particular person goes beyond the capacity of the purse of the welfare committee, then the case will be transferred to the pastor of the local assembly. In this period of 
economic recession (mainly from 2012 to date), especially in a situation when many states of the federation cannot pay the salaries of their workers for many months, the Pentecostals play prominent roles in serving as succour for the people in this category. Most of the Pentecostal Churches distribute food items to those who are in need, especially their church members. Even if all Christians in a community cannot be in a single place, the idea of giving support to their members who are in need is a practice that enhances their sustainability.

The Yorùbá people believe that one needs to exhibit the virtue of liberality and generosity in order to be vital in life. The Yorùbá people are hospitable; you don't need a formal invitation before you can visit somebody among them. To them, spiritual and material blessings accompany a liberal person and a giver never lacks as s/he continues to have abundance as encapsulated in the axiom, 'Òkè ni ôwọ afúnni ńgbé' - the hand of a giver is always on the top. Being on the top in this context means that such a giver will always prosper. It is the belief of the Yorùbá that the Supreme God watches over the people and he knows the givers and he is the only one that can pay them back by sending help to them in diverse ways. At the same time what one does for somebody today could be remembered by the recipient who would in turn pay it back in the future. Hence the saying, 'Oore loore ń wọ́ lê' - one good turn deserves another. It is also a possibility for giving to take the dimension of commensalism and complementarities. The above is the principle of interrelation and interdependency among the Yorùbá. It means that whatever one lacks the other person might have, and concerted efforts benefit the community people. Their belief is that, 'Láníhuntán kan kil niwo esin' - no person in the world possesses everything needed for vitality'. Hence, seeing the practice of giving moral, material and financial support to those who are in need could be seen as a way through which the Pentecostals in Yorubaland are deploying the Yorùbá principle of caring and sharing.

\section{Conclusion}

Pentecostalism has grown in Nigeria because of its cultural fit into certain indigenous worldviews and its response to the questions that are raised within the interior of the worldviews. It asserts that the indigenous worldview still dominates the contemporary African experience and shapes the character of African Pentecostalism. Pentecostalism becomes a solace from the harsh realities of the collapse of economies, prowling poverty, lapses of the state, and failed leadership. It has been observed that various social networks established by the Pentecostal Churches in southwestern Nigeria enhance meeting various needs of their members.

It is observed that many Pentecostals have contributed and are still contributing significantly to the needed religious, political and socioeconomic infrastructure for the sustainable development of Nigeria in the twenty-first century. Mention must be made that regardless of the important role that the Pentecostals are playing in the sustainability of the country there is a lot of criticism against them. However, the Pentecostal Churches have contributed to 
sustainable development in the following areas: humanitarian services, educational development, employment provision, spiritual and moral development, and social and ethical development.

\section{Note}

1 Ayegboyin and Ishola $(1997,16)$ classify Pentecostalism as 'a general term used to describe the groups and sects which have traditionally placed emphasis on the speaking and receiving of certain gifts of the Spirit, such as, speaking in tongues, prophesying and healing as a sign of the baptism of the Holy Spirit'.

\section{References}

Ajibade, Mobolaji Oyebisi. 2006. 'A Comparative Analysis of Social Network in Yoruba Culture and Nigerian Pentecostalism: Evidence from the Christ Way Church (CWC), Nigeria.' M.A. diss., Universität Bayreuth.

Ajibade, Mobolaji Oyebisi. 2010. 'Christ Way Church and Politics of Cultural Identity.' Ife Journal of Religions 6, no. 1: 20-41.

Ajibade, Mobolaji Oyebisi. 2013. 'A Study of Pentecostal Spirituality in Christian Home Video Films in South-Western Nigeria.' Ph.D. diss., Obafemi Awolowo University, Ile-Ife.

Ajibade, Mobolaji Oyebisi. 2014. 'The Role of Pentecostal Churches in Curbing Social Ills in Ife Central Local Government, Osun State.' Journal of National Association of Women in Colleges of Education (JOWICE) 18: 238-241.

Ajibade, Mobolaji Oyebisi. 2016. 'Filmic Construction of Pentecostal's Roles in Sustainable Democracy.' Journal of Nigeria Association for the Study of Religions 25, no. 2: 233-245.

Ayegboyin, Deji, and S. Ademola Ishola, eds. 1997. African Indigenous Churches: An Historical Perspective. Lagos: Greater Heights Publication.

Ayuk, Ausaji Ayuk. 2002. 'The Pentecostal Transformation of Nigerian Church Life.' Asian Journal of Pentecostal Studies 5, no. 2: 189-204.

Benjamin, C. D. Diara, and G. Onah Nkechinyere. 2014. 'The Phenomenal Growth of Pentecostalism in Contemporary Nigerian Society: A Challenge to Mainline Churches.' Mediterranean Journal of Social Sciences 5, no. 6: 395-402.

Corten, Andrew, and Ruth Marshall-Fratani, eds. 2001. Between Babel and Pentecost Transnational Pentecostalism in Africa and Latin America. Indiana University Press.

Gaiya, Musa A. B. 2015. 'Charismatic and Pentecostal orientations in Nigeria.' Nova Religio: The Journal of Alternative and Emergent Religions 18, no. 3: 63-79.

Hastings, Adrian. 1976. African Christianity. London: Geoffrey Chapman.

Lindhardt, Martin. 2010. 'Charismatic/Pentecostal Appropriation of Media Technologies in Nigeria and Ghana.' Journal of Religion in Africa, 28, no 3: 258-277.

McCain, Danny. 2013. 'The Metamorphosis of Nigerian Pentecostalism. From Signs and Wonders in the Church to Service and Influence in Society.' In Spirit and Power: The Growth and Global Impact of Pentecostalism, edited by Donald E. Miller, Kimont H. Sargeant, and Richard Flory, 160-184. New York: Oxford University Press.

Magbadelo, John Olusola. 2004. 'Pentecostalism in Nigeria: Exploiting or Edifying the Masses?' African Sociological Review/Revue Africaine de Sociologie 8, no. 2: 15-29. 
Maxwell, David. 2006. African Gifts of the Spirit: Pentecostalism and the Rise of a Zimbabwean Transnational Religious Movement. Oxford: James Currey.

Miller, Donald E., and Tetsunao Yamamori. 2007. Global Pentecostalism: The New Face of Christian Social Engagement. Berkeley: University of California Press.

NCEF (National Christian Elders Forum). 2018. 'The Imperative of Christian Participation in Governance.' 19 June 2018. www.proshareng.com/news/POLITICS/TheImperative-of-Christian-Participation-in-Governance-/40420.

Ojo, Mathews A. 1995. 'The Charismatic Movement in Nigeria Today.' International Bulletin of Missionary Research 19, no. 3: 114-118.

Olokor, Friday. 2018. 'Restructuring Should Dominate 2019 Polls - Christian Elders, Others.' 4 September 2018. https://punchng.com/restructuring-should-dominate-2019polls-christian-elders-others/.

Omotoye, Rotimi Williams. 2010. 'A Critical Examination of the Activities of Pentecostal Churches in National Development in Nigeria.' CESNUR: Centro Studi sulle Nuove Religioni. www.cesnur.org/2010/omotoye.htm.

Togarasei, Lovemore. 2015. 'Modern/Charismatic Pentecostalism as a form of Religious Secularisation in Africa.' Studia Historiae Ecclessiastica 41, no. 1: 56-66.

Uchegbue, Christian Onyenaucheya. 2013. 'The Place of the Church in the SocioPolitical and Economic Liberation of Nigeria.' Proceedings of the 1st Annual International Interdisciplinary Conference (AIIC): 141-154. Azores, Portugal.

Ukah, Asonzeh. 2006. 'Branding God: Advertising and the Pentecostal industry in Nigeria.' Liwuram: Journal of Humanities 13: 83-106. 


\title{
10 Aladura Churches as agents of social transformation in South-West Nigeria
}

\author{
Akinwumi Akindolie
}

\section{Introduction}

Religious organisations are one of the workable factors that make lives meaningful through their social transformative activities, which change people and communities in general. Corroborating Nabofa's theory of religion $(1988,54)$, Scharf remarks that religion always permeates, mediates and pervades the lives of persons, relationships, institutions, processes and structures which by implication serve as social functions $(1970,21)$. Religion is not all about spirituality, it is also a social phenomenon (Akindolie 2012, 6). Apart from spiritual experience inherent in religious practices and beliefs, there are lots of physical manifestations of religious events that transform the social life of people. This is supported by the functionalist perspective, which considers religion to be needed by society to function well (Haralambos and Holborn 2008, 396). This is contrary to some western social thinkers who stress that religion is a mere illusion and that the phenomenon will disappear or become progressively attenuated when there is an expansion in modern globalisation (Borowik 2002, 239-252). However, religion has disappeared nowhere but transformed everywhere (Akindolie 2012, 6).

Several scholars, for example Oyewole (2004, 21), Akindolie (2012, 1), Tachin (2019, 393), Familusi (2010, 158-160), Familusi and Oke (2011, 90-91) and Johnstone (2001, 181-182) among others, have written extensively on religion as a tool for social transformation. However, the literature has concentrated on the social contributions of Mission Churches and Pentecostal Churches and their social transformation activities, while little attention has been paid to African Initiated Churches. 'While it has been acknowledged that many [African Initiated Churches] provide coping mechanisms in adverse environments, support in social transformation and social capital, little information is available on their role as development actors' (Öhlmann et al. 2016, 1). In line with this, there is a need to look at the social contributions of Aladura Churches in South-West Nigeria, a West African expression of African Initiated Christianity. Hence this chapter traces how Aladura Churches' social activities help to transform the people and communities around them. In addition to existing literature, the chapter relies on interview material from the 
Nigeria field study of the Research Programme on Religious Communities and Sustainable Development headed by Marie-Luise Frost in the framework of the research project 'Potentials of Cooperation with African Initiated Churches for Sustainable Development'. ${ }^{1}$

\section{The social transformational role of religion in Nigeria}

Writing on the subject of education as a means of transformation, Oyewole stresses that there is no gainsaying about the fact that the coming of Christianity and Islam to African countries brought about transformation in their educational systems. He affirms that before the advent of the white Europeans and Arabs to African countries the system of education was an informal one. According to Oyewole, Nigerians exposed to western education developed a sense of transformation, thereby leading to improved educational standards of the African leaders and members of the entire society (Oyewole 2004, 21).

In addition, Ositelu describes missionaries' contribution as a factor in the growth of national consciousness through the establishment of newspapers. One example is the newspaper Iwe Iroyin founded by an Anglican missionary in Nigeria, Henry Townsend of the Church Missionaries' Society (CMS), in 1859 (Ositelu 2010, 106). Moreover, Europeans missionaries contributed to the linguistic unification of African languages. According to Adeoba (2012, 57), missionaries did not only spread the use of English as a lingua franca, but also standardised Nigerian languages through the translation of the Holy Bible. Local dialects were unified into common language for several ethnic groups. This standardisation of languages promoted the functioning of administration, politics and commercial activities (Adeoba 2012, 48-49).

Oyewole furthermore observes that Islamic education served as a tool for educational change by the teaching of converts to read the Holy Quran - the sacred text of Islam. Today, there are many primary and secondary schools as well as colleges that were established by Islamic missionaries (Oyewole 2004, 21).

Bourdillon further investigates the spiritual level of health where he stated that religious organisations have contributed greatly to the improvement of people's health. In this situation, Independent and Pentecostal Churches and some Islamic organisations, especially those advocating prophetic healing, are easily accessible and often render free healing services based largely on spiritual means faith, prayer and fasting. They also use consecrated water, olive oil and the support of the believing community in their healing services (Bourdillon 1991, 146). This has been attested to by many beneficiaries of these spiritual healings otherwise known as cura divina (divine healing) which constitute a reality in the African experience (Ayegboyin and Ishola 1997, 29).

Familusi opines that religion has a strong influence on politics in various aspects such as style of governance, policy formation and electoral processes. Again, he admits that religious ethical teaching influences the adherents positively and such impact thus provides good leadership and obedient followership. 
In relation to this, Familusi points out that religion as an agent of social control helps to keep people within the norm of the society, which is the real basis of politics. Thus, religion as an agent of transformation prepares the mind of man to be a good politician and citizen who will always fall back upon his religion to guide him in his social activities (Familusi 2010, 158-160).

Similarly, Dzurgba submits that religion has a pervading and powerful influence on political institution and process. He asserts that it is an agent of political socialisation, directly or indirectly. He establishes that religion has a significant influence on party affiliation, campaign hustling, voting behaviour and pressure group formation. In his words, the religious influence that brings about change in these aforementioned political exercises may be overt or covert, depending on the nature of such a political process (Dzurgba 1991, 54). He asserts that in a dominant Christian community, campaign hustling may give emphasis to Christian' interests such as the return of schools established by missionaries to churches, a better policy on pilgrimage to Israel and favourable government policy on Christian hospitals and clinics.

Corroborating these claims in a pluralistic society like Nigeria, Dzurgba puts forward that any political party that wants to succeed must take into consideration the involvement of different religious adherents, notably Christians and Muslims. For instance, in the 2011 Nigerian elections, a majority of the political parties' leaders were either from Christian or Muslim communities. However, in a system like this, people get assurance from the party for which they will vote for to represent their interests at local, state and national levels. Thus, Dzurgba $(1991,54)$ states that politicians rarely ignore or make mistakes about religion during campaign hustling; it is at this time that some politicians become born again. Voting behaviour is transformed by the religious faith of voters and by implication a religious consideration plays an important part in a voter's decision as to whom to vote for in a particular election. Furthermore, he adds that political pressure groups might be formed on the basis of the various religious institutions of Christianity, Islam and African traditional religion.

Dzurgba is also of the opinion that religious thought and behaviour inspire honesty in business as it is said that 'honesty is the best policy'. It does not allow traders to be associated with fraudsters. By implication, religion helps good reputation and this in turn paves the way for societal transformation. Similarly, Johnstone (2001, 181-182) states that, along with honesty, dedication and commitment, religious faith inspires initiative, diligence and efficiency of labour. All these bring about increased productivity in business. With work ethics, business could flourish well, hence, the transformational role of religion in the economy. In conclusion, from the literature reviewed above, we know that scholars expatiated on religion and transformation from different perspectives, but no adequate works have been done on the contribution of Aladura Churches and their social transformation activities.

On Mission and Pentecostal Churches' current contributions towards social transformation in Nigeria, Familusi and Oke, for example, discuss Christian organisations' engagement in poverty alleviation. According to them, the Catholic 
Church for instance, through the Justice Development and Peace Commission (JDPC), has multifarious poverty reduction mechanisms in various Nigerian dioceses. Members and non-members alike benefit from vocational training, microcredit schemes and charity offered by the church. Associated with this, the Owerri Archdiocese, for example, runs a massive farm with animal husbandry and crop production on over 80 hectares of land irrigated with water from the Onumurukwa River (Familusi and Oke 2011, 90). Furthermore, the Methodist Church in Nigeria under the auspices of the United Methodist Committee on Relief inter alia contributes to poverty alleviation through agricultural activities, microcredit schemes and microenterprise development (Familusi and Oke 2011, 91). The Anglican Church has been equally proactive in poverty alleviation, as has the Baptist Church (Nigerian Baptist Convention 2009, 6-11). With respect to Pentecostal Churches, Oguntoyinbo-Atere provides an exhaustive description of the Redeemed Christian Church of God's programmes for the poor in Lagos. Among other things, the church engages in a God's provision programme, which takes care of the old and the handicapped, single mothers, the jobless, helpless orphans and the sick. The Christian Association of Nigeria (CAN), according to Atere, makes a difference in feeding prison inmates and the destitute, and runs a scholarship scheme for poor students (Oguntoyinbo-Atere 2005, 188-197). Akindolie (2012) has described the social work of the Chapel of Resurrection, a joint Methodist and Anglican campus congregation at the University of Ibadan. This church implements social transformation programmes for indigent people. Widows, widowers, students and others who solicit financial and other assistance are being taken care of. Apart from welfare, the church organises a 'Resurrection Youth Education Centre' for extramural classes for candidates preparing for various examinations (Akindolie 2012, 68).

From the above, we appreciate the contributions of Familusi and Oke (2011), Oguntoyinbo-Atere (2005) and Akindolie (2012) among others towards Mission and Pentecostal Churches' social transformation programmes. This chapter intends to complement the existing literature by providing a case study focusing on Aladura Churches in South-West Nigeria.

\section{Aladura churches}

In the Nigerian context, the churches emerging from the second wave of African Initiated Christianity (Spiritual/Indigenous Churches, as outlined in the Introduction to the volume) are commonly known as the Aladura (Praying Churches) or Ijo Elemi (Spiritual Churches). According to Ayegboyin, they are referred to as Aladura because of their intense fervour for energetic prayer. They are called Ijo Elemi (Yoruba) and Ishoshierrhi (Urhobo) because of their emphasis on the spirit while their interest in faith healing and exorcism has earned them the name prophetic and healing ministries (Ayegboyin 2017, 18).

Four churches designated by Ayegboyin as belonging to this group are: the Cherubim and Seraphim Movement (C \& S), the Christ Apostolic Church (CAC), the Church of the Lord (Prayer Fellowship) Worldwide ${ }^{2}$ and the Celestial 
Church of Christ (CCC) (Ayegboyin 2017, 18). All four of these churches started within the South-West zone of Nigeria among the Yoruba-speaking population and are known as Aladura Churches. The term 'Aladura' means 'owner of prayers'. The churches were so named because of the high premium which they placed on prayer, which is one indication of their high level of spirituality. This distinctive form of spirituality which some scholars have aptly referred to as Ijo Elemi 'Aladura spirituality' has in many ways labelled the churches as more aligned with spiritual activities than involvement with social transformation activities (Ayegboyin 2017, 18; Pobee and Ositelu 1988, 27-330). The Aladura Churches rapidly expanded throughout Yorubaland during a revival movement in the 1930s, becoming an important feature of western Nigerian society. Joseph Ayo Babalola (1959), a Yoruba Anglican and public works employee, had a series of visions that brought him to the Precious Stone Society. He went on to become a General Evangelist in the CAC, which would become Nigeria's largest Aladura Church. He emphasised using 'water of life' (blessed water) in healing rituals. Other important church leaders in that period were Josiah Olunowo Ositelu of Church of the Lord Aladura, Moses Orimolade Tunolase of Cherubim and Seraphim Church and Samuel Bilewu Oshoffa of Celestial Church of Christ.

\section{Aladura Churches as agents of social transformation}

Aladura Churches in Nigeria are known to be Spiritual Churches. It is believed by Africans that Mission Churches created a spiritual vacuum. Mission Churches failed to attend to certain spiritual challenges and needs. Aladura Churches are able to meet them. This can be corroborated in the words of Ayegboyin and Ishola $(1997,29)$ :

In West African nations where there are very few hospitals, and costly medicine is beyond the reach of the majority, one would reasonably expect that the promise of cura divina (divine healing) would attract a number of people. Indeed, sickness is by far the most common reason which people give for attending AICs. Testimonies of healings, soundness and miracles are heard from many about their answered prayers. In quite a number of cases those concerned claim that they first went to the hospitals, and or consulted traditional healers. Then, they resorted to an indigenous church when the foreign physicians and herbalist failed them.

However, Aladura Churches are not only about spirituality. They have contributed immensely to social transformation and human development and continue to do so. Some of these transformation activities are discussed below.

\section{Educational services}

Aladura Churches have improved educational standards in various ways in South-West Nigeria (Oyewole 2004, 22). This is evident in their establishment 
of elementary and secondary schools. Some of the leaders of Aladura Churches have been founders of these schools. For instance, some elementary schools that were founded by Aladura Churches are: Aladura Comprehensive High School, Anthony Lagos, the Church of the Lord Nursery and Primary School, Ogere Remo, Ogun State, Saint John Primary School, Orimolade, Ondo, Orimolade Community Grammar School, Ondo, Cherubim and Seraphim College, Surulere, Lagos; and Celestial Church of Christ High School, Oke Ado, Ibadan, to mention but a few.

Unlike the Pentecostal Churches or the Mission Churches in Nigeria (Adedibu 2018, 5), Aladura churches in Nigeria presently have limited investment in university education. The observable disparity in investment in private tertiary education might be due to a lack of forward planning and financial means. The leading university is Joseph Ayo Babalola University, founded in 2006 by the CAC, in Ikeji-Arakeji, Osun State. The second university is the proposed and almost complete Moses Orimolade University in Omu Aran, Osun State, under the auspices of the Cherubim and Seraphim Church.

However, in the past some of the primary and secondary schools established by Aladura Churches have been taken over by the Nigerian government in SouthWest Nigeria due to financial constraints and lack of manpower (interview Adebayo Kehinde 2017). Apart from this, Aladura Churches in their educational capacity organise extramural classes for candidates preparing for examinations such as the Senior Secondary Certificate Examination and the University and Tertiary Matriculation Examination (interview Israel Akinadewo 2017). This programme is also open to children and wards of members and non-members after registration with a token fee. The churches are responsible for the payment of teachers' salaries, while some members volunteer to teach without remuneration. Some of the Aladura Churches in Nigeria organise other educational training and seminars for church members and non-members. The churches engage in educating their young members by organising seminars on sex education, marriage, and job opportunities, and workshops on security and other themes. Youth empowerment is another social involvement, whereby youths are trained in different crafts such as arts, hair barbing and hairdressing, netting, soap making, shoe making and tailoring (interview Solomon Alao 2017).

Vocational and technological training is one of the ways in which individuals are empowered and become self-reliant in our contemporary society. The import of this development has seen the proliferation of various entrepreneurships through vocational training by many AICs. Some of these ventures are sole proprietorship requiring minimal financial outlay such as interior decoration, soap making, the use of pottery and traditional cloth weaving using contemporary approaches. This training has contributed to economic independence and the survival of traditional African culture through the production of hybrid African attires as well as indigenous cosmetics and jewellery by these mediumscale entrepreneurs.

The uniqueness of the multifaceted interventionist approaches of AICs is evident within the social strata of most of these churches. Participants are 
encouraged to develop various streams of income and be self-employed to contribute to their emancipation from poverty and social vices, which are noted to be a by-product of a lack of gainful employment opportunities, economic dependency on the state and the challenge of moral and fiscal corruption of the ruling class in Africa. The results of this vocational and technological training have in different ways transformed life within and outside the community (Oyewole 2004, 21).

\section{Health services}

The World Health Organization (WHO) defined health in its broader sense in 1948 as a state of complete physical, medical and social well-being and not merely the absence of infirmity (Jakab 2011, 3). Attempts are being made by Aladura Churches to improve people's health in various communities (interview Bisi Ademosun 2017).

My impression on the basis of the field study mentioned above was that some of the health services provided by Aladura Churches have contributed in immense ways to members' and non-members' health status. For instance, women's societies and men's societies of some Aladura Churches organise healthcare services during their annual anniversary. Notable health services organised by a women's society include keep fit exercises, first-child medical advice and medical check-ups while the men's societies consult medical doctors for free eye treatments, blood pressure tests, blood sugar tests, diagnoses, genotype tests, urine tests, HIV/AIDS tests among others. Apart from the payment of hospital bills of the people that need medical assistance, such as those affected by motor accidents, fires, protracted illness, to mention but a few, it is reported that much money is spent on health services every year by the Salem Evangelical Church of Christ (interview Magnus Atilade 2017). Under this scheme, the church pays for the drugs and medical treatment of people needing medical assistance and their progress monitored.

Salem Welfare Outreach of Nigeria, a ministry of Salem Evangelical Church of Christ, has also been proactive in health issues in society. This is carried out by organising free medical services such as health talks lectures on breast cancer and the prescribing of drugs by medical practitioners. The Hospital Visitation Committee of some churches embarks on visiting the sick in the hospital and at home. This visitation is sometimes accompanied by the provision of some basic needs like food items. This committee also encourages blood donation, usually for their fellow members who are in need of blood whenever medical practitioners visit from the hospital. The committee also sees to the payment of hospital bills after the verification of the person in question (interview Abdulralman 2017).

\section{Political activities}

In Nigeria, many people believe that politics is a dirty game and therefore decide not to participate in politics. However, as I have argued elsewhere, if it is 
a dirty game, then people who are clean are needed to clean up the mess (Akindolie 2012, 56). This seems to be what Aladura Churches have been trying to do. Aladura Churches have, over the years, encouraged their members to participate actively in politics. Many church leaders encourage their members to participate in elections (Akindolie 2012, 56). As Bompani observes with reference to the South African context, AICs might be less involved in national political debates than Mission Churches, while being active at a local level (Bompani 2008, 665-677). This resonates with the Nigerian context. For instance, part of the social work of the Church of the Lord (Prayer Fellowship) Worldwide is to participate in elections, monitor and sensitise people by encouraging them to vote and telling them what and what not to do with the help of radio and television adverts, posters and handbills. The church also conducts public political sensitisation programmes for their surrounding communities during local, state and presidential elections. These go a long way in helping to change the political orientation of the members and non-members towards involvement in free and fair elections from the grass roots to the national level (interview Babatunde Gbogboade 2017).

An example of international political involvement is the Church of the Lord (Prayer Fellowship) Worldwide's advocacy on nuclear disarmament. Its Primate, the Most Rev. Dr Rufus Ositelu, is a strong advocate for peace at the international level and has on numerous occasions condemned nuclear weapons. Speaking at the Second Annual Interfaith Meeting commemorating the 71st anniversary of the bombing of Hiroshima and Nagasaki organised by the Peace, Justice and Empowerment Movement in London on Friday 16 September 2016 he said: we believe that using the energy of the atom in ways that threaten and destroy life is a sinful misuse of the fundamental building blocks of God's creation (interview Adebayo Kehinde 2017).

\section{Challenges and prospects}

\section{Insufficient funds}

It is established that one of the major social problems facing almost every organisation in Nigeria is insufficient funding (Akindolie 2012, 94). This is no different for Aladura Churches in Nigeria, since these are self-funding organisations. As a result, it is impossible for the religious bodies to improve upon their social welfare packages, payment of hospital bills, provision of recreation centres and provision of scholarship funds for the indigent. Thus, insufficient funding limits the achievements of the church in its social responsibility. Insufficient funds lead to a cut in the many social transformation aids given to beneficiaries. The provision of many social services is abandoned because of inadequate funds.

Restriction is another implication of inadequate funds. It manifests itself in many cases where conditions are set for the beneficiaries that are seeking assistance mostly among indigent students. In other words, beneficiaries are expected to meet more stringent conditions before they can be financially assisted. This 


\section{Akinwumi Akindolie}

restricts others who might need such assistance as only a few out of many people can be supported. In many cases this screening method is a result of limited resources. The fact remains that, due to the local intensive way of generating funds in the religious bodies in Nigeria, especially in African Initiated Churches, it is evident that the Aladura Churches do find it difficult to embark on large social transformational projects (interview Magnus Atilade 2017).

\section{Shortage of personnel}

It is quite clear that a lack of personnel has seriously reduced the quality of social transformation activities among religious bodies in Nigeria and prevented them from achieving their goals (Akindolie 2012, 96).

Due to the stress inherent in the organisation and administration of social services, it is evident that people find it difficult to participate in the long process of serious verification, counselling, training and monitoring of beneficiaries whenever they apply for social aid. This is underscored by the fact that these activities do not have monetary value attachment. Therefore, with all these shortcomings, people find it inconvenient to join the organisation because they cannot cope with the conditions of attending meetings, close monitoring, visitation, planning and risk taking/management. Moreover, from the field study during this research, it was noted that due to the associated challenges of development in a country like Nigeria as a Third World country, a lack of technical know-how in terms of management, administration and project management exists in comparison to the developed world. The multiplier effect of this development might be responsible for the inadequacies in various social service initiatives of AICs. Information gathered from the field studies showed that many of the personnel were not always available to diligently discharge their duties for the progress of these social services. However, this may be connected with the volunteer nature of the Aladura Churches' social transformational services (Akindolie 2012, 99).

\section{Conclusion}

From the above, it is evident that, Aladura Churches have contributed and are still actively contributing to social transformation in the areas of education, politics and health services to members and non-members. Therefore, Aladura Churches are not only about spirituality, as tagged by some scholars in the existing literature. Despite the challenges faced by the religious organisations in terms of insufficient funds and shortage of personnel due to the fact that the churches were said to have been almost exclusively patronised by the poor, the illiterate and the sick at its inception, these days we find among the members persons occupying social and economic positions in society. Among them are engineers, lawyers, senior police and army officers, professors, medical personnel and business tycoons. Thus, this positive change has enhanced the various innovations initiated by the Aladura Churches in their social transformation 
activities being carried out in different ways. Therefore, as much as the Aladura Churches will continue in their provision of social services by tailoring their operations to meet the social needs as well as the spiritual needs of society, there is still the prospect of further growth and development of the Aladura Churches in Nigeria and Africa as a whole.

\section{Notes}

1 The research project was awarded to Humboldt University Berlin by the German Federal Ministry of Economic Cooperation and Development. The author of this chapter took part in the Nigeria field study as a junior researcher.

2 Previously called the Church of the Lord (Aladura).

\section{References}

Adedibu, Babatunde A. 2018. 'The Changing Faces of African Independent Churches as Development Actors across Borders.' HTS Teologiese Studies/Theological Studies 74 (1). https://doi.org/10.4102/hts.v74i1.4740.

Adeoba, A. O. 2012. Religious Organization and Social Transformation. Dynamic Publishers, Lagos.

Akindolie, Akinwumi Ambrose. 2012. 'Religious Organisation as Tools for Social Transformation of University of Ibadan Community.' Master's thesis, Department of Religious Studies, University of Ibadan, Nigeria.

Ayegboyin, Deji Isaac. 2017. 'Taxonomy and Revolution in African Christianity: The Nigerian Experience.' Inaugural lecture for the 2016/2017 academic session, 9 November, 2017, University of Ibadan.

Ayegboyin Deji Isaac, and S. Ademola Ishola. 1997. African Indigenous Churches: An Historical Perspective. Lagos: Greater Height Publications.

Bompani, Barbara. 2008. 'African Independent Churches in Post-Apartheid South Africa: New political interpretations.' Journal of Southern African Studies 34, no. 3: 665-677. http://dx.doi.org/10.1080/03057070802259928.

Borowik, Irena. 2002. 'The Roman Catholic Church in the Process of Democratic Transformation: The Case of Poland.' Social Compass 49, no. 2: 239-252.

Bourdillon M. F. C. 1991. 'Religion, Medicine and Healing.' In Religion and Society in Nigeria. Historical and Sociological Perspectives, edited by Jacob K. Olupona, and Toyin Falola, 146. Ibadan: Spectrum Books.

Dzurgba, Akpenpuun. 1991. An Introduction to Sociology of Religion. 2nd edn. Ibadan: Centre for External Studies, University of Ibadan.

Familusi, Olumuyiwa Olusesan. 2010. 'Religious Politics and Its Implication for Sustainable Development in the Post Independence Nigeria.' In Journal of Sustainable Development in Africa 12, no. 5: 158-600.

Familusi, Olumuyiwa Olusesan and Oke, Olusegun P. 2011. 'A Christian Dimension to Poverty Discourse in Nigeria.' Orita: Ibadan Journal of Religious Studies 43, no. 2: 75-94.

Jakab, Zsuzsanna. 2011. 'Health 2020: A New Policy for a New Era.' Presentation held at the 14th European Health Forum Gastein at Bad Hofgastein, Austria, 6 October 2011. www. euro.who.int/_data/assets/pdf_file/0003/152175/RD_Gastein_pres_06Oct.pdf?ua=1.

Johnstone, Ronald L. 2001. Religion in Society. Upper Saddle River, NJ: Nancy Roberts.

Haralambos, Michael, Martin Holborn, and Robin Heald. 2008. Sociology Themes and Perspectives. 7th edn. London: Harper Collins. 


\section{Akinwumi Akindolie}

Nabofa, M. Y. 1988. General Introduction to the Study of Religion. Ibadan: Department of Adult Education, University of Ibadan.

Nigerian Baptist Convention. 2009. 'Kingdom Expansion: Our Coast through Social Ministry.' In Annual Convention Handbook 96: 6-11.

Öhlmann, Philipp, Marie-Luise Frost, and Wilhelm Gräb. 2016. 'African Initiated Churches' Potential as Development Actors.' HTS Teologiese Studies/Theological Studies 72, no. 4. https://doi.org/10.4102/hts.v72i4.3825.

Oguntoyinbo-Atere, M. I. 2005. 'The Redeemed Christian Church of God Programme for the Poor in the Context of Lucan Teaching.' Ph.D. thesis, Department of Religious Studies, University of Ibadan, Nigeria.

Ositelu, Gideon Adebandele. 2010. Christianity in West Africa up to 1914. Ibadan: Hope Publishers.

Oyewole, Yahya. 2004. 'Religious Organizations and Progressive Social Change: A Case Study of Ansar-ud-Deen Society of Nigeria.' Islamic Studies 43, no. 4: 631-651.

Pobee, John S., and Gabriel Ositelu. 1988. African Initiatives in Christianity: The Growth, Gifts and Diversities of Indigenous African Churches: A Challenge to the Ecumenical Movement. Geneva: WCC.

Scharf, Betty R. 1970. The Sociological Study of Religion. London: Hutchinson and Company.

Tachin, P. 2019. 'The Nigerian Church in Its Social Context in African Christianity in Local and Global Contexts.' In A Festschrift in Honour of Rev. Professor Isaac Deji Ayegboyin at 70, edited by S. A. Fatokun, J. K. Ayantayo, O. O. Familusi, S. M. Mepaiyeda, and S. O. Okanlawon, 393.

\section{List of interviews}

Abdulralman. 2017. Prophet Salem Evangelical Church of Christ Ikorodu Road, Ilupeju, Lagos.

Adebayo Anthony Kehinde. 2017. Deacon Ecumenical Officer, Church of the Lord Aladura in Ogere, Ogun State.

Akinadewo Israel. 2017. Baba Aladura, Mutailatu Church Worldwide, Mayfair Ajah, Lagos.

Alao Solomon. 2017. Most Elder Apostle Dr Church Leader of the Sacred C\&S Church Holy Mountain of Salvation, Aguda Surulere, Lagos.

Bisi Ademosun. 2017. Baba Aladura, Prophet, Mount Jieawowrrar All Saint Church of Christ Aladura Worldwide, Odogbolu, Ogun State.

Emmanuel Gbogboade. 2017. Bishop, Principal Aladura Theological Institute and the Bishop of Ogere Diocese, Church of the Lord Aladura in Ogere.

Magnus Atilade. 2017. Archbishop Prof. Leader of Gospel Baptist Conference of Nigeria. 


\title{
11 Distinguished church leader essay
}

\author{
Aladura theology - the case of the \\ Church of the Lord (Prayer \\ Fellowship) Worldwide
}

\author{
Rufus Okikiola Ositelu
}

\section{Introduction}

The theology of the Church of the Lord (Prayer Fellowship) Worldwide (a.k.a. Aladura) is based on the Scriptures, natural law, and Divine Revelation - 'The LORD says', as interpreted authoritatively by the Supreme Council of Prelates (SCP), which is also known as the Council of Bishops. The Church of the Lord's (Prayer Fellowship) Worldwide (TCLPFW) is manifested in its six tenets.

\section{The tenets of the Church of the Lord (Prayer Fellowship) Worldwide}

TCLPFW is conscious of its mission to spread the good news of our Lord Jesus Christ to every nook and corner of the world. The cross of Christ Jesus is our guide. TCLPFW is a revealed covenant church from above. The solid foundation of the church is laid on love, faith and hope. Every adherent of the church is enjoined to abide and practise these virtues.

The six tenets of the church can be described as:

1 Pentecostal in power;

2 biblical in pattern;

3 evangelical in mission;

4 prophetic in ministry;

5 social in responsibility; and

6 ecumenical in outlook.

\section{Brief introduction of Aladura tenets}

Biblical in pattern in the sense that in all matters of faith, conduct, doctrine, rituals, character and discussions, our supreme court of appeal is the Holy Bible. Thus, the Holy Bible is our spiritual constitution.

Pentecostal in power in the sense that the Spirit of our Lord Jesus Christ is the administrator of the church through which the church is guided, directed, 
filled, influenced, administered and managed. Our power of attorney is: 'In Jesus's name'.

Evangelical in mission in the sense that we carry the Gospel to the nooks and corners of the world, and we preach the good news to all, irrespective of background, race or gender. Matthew says:

Therefore, go and make disciple of all nations, baptizing them in the name of the Father and of the Son and of the Holy Spirit, and teaching them to obey everything I have commanded you. And surely I am with you always to the very end of age.

Prophetic in ministry in the sense that God endowed the founder of the church and promised to endow all that will follow him with prophetic virtue for the benefit of mankind. This is the genesis and the pillar on which TCLPFW is anchored. The gifts of prophecy, dream, vision, revelation, speaking in tongues, healing, signs and wonder, teaching and administration, and so on are bestowed on the church. On outpouring of the Spirit, the Lord said in Joel:

And afterward, I will pour out my Spirit on all people. Your sons and daughters will prophesy, your old men will dream dreams, your young men will see visions. Even on my servants, both men and women, I will pour out my spirit in those days.

Social in responsibility in the sense that the church believes it should be a blessing to the community where the church is situated and the inhabitants of the state in general. We therefore endeavour to provide social amenities through the NGO of the church - the Justice, Equity, Peace and Empowerment Foundation (JEPEF).

Ecumenical in outlook in the sense that we embrace and encourage brotherly and sisterly love among the believers, and we do not forsake the saints, for the prayer of the High Priest - our Lord Jesus Christ - for the church is, 'That they may be one' (John 17:21). We believe in 'unity in diversity' and share in fellowship, unity in the bond of peace with all believers who worship and serve Jesus Christ as Lord, Saviour and Redeemer. We are told that:

The body is a unit, though it is made up of many parts; and though its parts are many, they form one body. So it is with Christ. For we were all baptized by one Spirit into one body - whether Jews or Greeks, slave or free - and we were all given the one Spirit to drink.

And our Lord Christ Jesus in John said: 
My prayer is not for them alone, I pray also for those who will believe in me through their message, that all of them may be one, Father, just as you are in me and I am in you. May they also be in us so that the world may believe that you have sent me.

\section{Sacraments and festivals}

Formal Aladura worship is ordered by means of the liturgy, which is regulated by the authority of the church. The Aladura Church celebrates all the major Christian sacraments and festivals, including baptism by immersion, confirmation, holy communion, penance, reconciliation, anointing, holy orders, observation of Easter and Christmas seasons. Aladura believes that man comes from God and will eventually go back to God. 'For it is appointed for men to die once, but after this judgment' (Hebrews 9:27).

\section{Apostles' Creed}

We believe in the Apostles' Creed (Nicene Creed), and it is thus recited every Sunday as a form of reminder during the Worship Service. We believe in the African tradition and thus feel free to practise Christianity within our cultural context as long as such practice agrees with the teachings of the Holy Bible. According to 2. Corinthians 3:17; we are told: 'Now the Lord is the Spirit; and where the Spirit of the Lord is, there is liberty'.

\section{The Holy Trinity}

We believe in the triune God (the Holy Trinity) - God the Father, Son and Holy Spirit - the God-Head, one God in essence, but three personalities - the Father decrees, the Son carries out the instruction, through the power of the Holy Spirit (Matthew 29:19).

\section{Salvation (soteriology)}

We believe that salvation comes through Jesus Christ alone. Jesus Christ is the Saviour of humankind (John 1:29). In fact, the whole sacrificial system established by God in the Old Testament set the stage for the coming of Jesus Christ, who is the perfect sacrifice God would provide as atonement for the sins of His people (Romans 8:3; Hebrews 10). The sacrifice of lambs played a very important role in the Jewish religious life and sacrificial system. When John the Baptist referred to Jesus as the 'Lamb of God who takes away the sin of the world' (John 1:29):

For the grace of God that brings salvation hath appeared to all men, Teaching us that, denying ungodliness and worldly lusts, we should live soberly, 
righteously, and godly, in this present world; Looking for that blessed hope, and the glorious appearing of the great God and our Saviour Jesus Christ; Who gave himself for us, that he might redeem us from all iniquity, and purify unto himself a peculiar people, zealous of good works.

(Titus 2:11-14)

\section{Ten Commandments}

We believe in the Ten Commandments and the commandments of Jesus Christ (2. Timothy $3: 16$; 1 . Timothy 1:8; Exodus 20:1-17; Deuteronomy 5:1-21; Matthew 5:17-19; 22:37-40; Romans 3:31; Mark 12:28-34).

\section{Priesthood of All Believers}

We believe in the ordination of men and women as priests for the work of God in the Vineyard (ministry). 'But ye are a chosen generation, a royal priesthood, an holy nation, a peculiar people; that you may proclaim the praises of Him who called you out of darkness into His marvellous light; his marvellous light' (1. Peter 2:9). The primate, cardinals, archbishops and bishops are all members of the SCP, with special responsibilities as stated in the constitution of the church, including the church provinces, dioceses, aones and the local church overseers.

\section{Succession}

The succession of the primate (the administrative and spiritual leader of the church) is regulated in the constitution of the church. The incumbent primate may proclaim his successor as directed by the Holy Spirit. In the absence of any proclamation, and after the demise of the primate, the board of trustees of the church will summon the SCP to the Holy Mount Tabieorar to fast and pray for seven days during which they will inquire of the Lord God who should be the next primate (Exodus 18:15; 1. King 22:5, 7; 2. Chronicles 18:6; Genesis 25:22; Judges 18:5; Acts 6:3-6).

\section{Contemporary issues}

Every religion has always been practised within the cultural context of its believers. For no religion ever existed in a cultural vacuum - Hinduism, Jainism, Buddhism, Confucianism, Taoism, Shintoism, Zoroastrianism, Judaism, Christianity, Islam, etc., they all came into being in a cultural existence. African Initiated Churches, therefore, should feel free to practise Christianity within their cultural context as long as such practice agrees with the teachings of the Scriptures (2. Corinthians 3:17). They are therefore not apologetic of having a culture which respects the elders and accords much more respect to a Supreme Being (Creator). Christian ethics recognise the cultural differences and do not demand that one gives up his/her own culture in order to keep God's commands. The Christian ethic is anchored ultimately and firmly in the unchanging nature of a 
God of perfect love and justice. The Christian view of ethics has a superior source (God), a superior manifestation (Jesus Christ), as well as a superior declaration (Holy Bible), and superior motivation (the love of Christ Jesus).

\section{Practices and observances}

1 Efficacy of prayer and fasting - TCLPFW believes in the efficacy of prayer and fasting (Matthew 17:21; Mark 9:29). Jesus Christ said: 'So He said to them, "This kind can come out by nothing but prayer and fasting"' (Mark 9:29; NKJV).

2 Mode of worship - TCLPFW and other African Initiated Churches have changed the mode of Christian worship, observances and practices dramatically in Nigeria, Africa and other parts of the world.

3 Recognition of lack of life in Mission Churches - a commentary in one of the publications of the Christian Council of Nigeria (CCN) in the year 1960 about the Aladura Churches: 'The Aladura Church movement had risen out of dissatisfaction with the life of the Mission Churches (or its lack of life)'. This recognition and adoption of the Aladura practices by the European/American mission is visible in Africa and other parts of world.

4 Pacesetters in using local lyrics - the African Initiated Churches are pacesetters in the use of local lyrics during worship services.

5 Ordination of women-TCLPFW is the pacesetter in the ordination of women. The church believes in the Royal Priesthood of all believers. 1. Peter 2:9; says: 'But you are a chosen generation, a royal priesthood, a holy nation, His own special people, that you may proclaim the praises of Him who called you out of darkness into His marvelous light' (1. Peter 2:9; NKJV).

6 Speaking in tongues - speaking in tongues is a gift of the Holy Spirit, which God has immeasurably endowed on the African Initiated Churches. As a matter of fact, some Christians of other denominations and Christian families are afraid to attend the worship service of the Aladura Churches as their past, present and future may be exposed by the Holy Spirit. Paul the Apostle told the Corinthians and in extension all Christians: 'Therefore, brethren, desire earnestly to prophesy, and do not forbid to speak with (in) tongues' (1. Corinthians 14:39).

7 Prophecy - is a gift from the Holy Spirit and it is the foundation and one of the tenets of TCLPFW. We are told in 1. Corinthians 14:24-25:

But if all prophesy, and an unbeliever or an uninformed person comes in, he is convinced by all, he is convicted by all. And thus the secrets of his heart are revealed; and so, falling down on his face, he will worship God and report that God is truly among you.

(1. Corinthians 14:24-25; NKJV)

We are therefore to: 'Pursue love, and desire spiritual gifts, but especially that you may prophesy' (1. Corinthians 14:1; NKJV). 
8 Respect for the Lord God and removal of shoes in the temple - the white garment (a.k.a. Aladura) church members remove their shoes when about to step into the Temple of God. They do this out of the African tradition of respect for elders and people in authority and moreover as a sign of reverence for the Supreme Being (the Lord God Almighty).

9 White garment - white is the symbol of purity and righteousness. For TCLPFW, the wearing of white garment serves as a reminder to our members and followers that we should be holy for our heavenly Father is holy. 'And you shall be holy to Me, for I the Lord am holy, and have separated you from the peoples, that you should be Mine' (Leviticus 20:26; NKJV). '[B]ecause it is written, "Be holy, for I am holy"' (1. Peter 1:16; NKJV). The white garment also serves as a 'leveller', thus freeing individuals from the worry of 'What am I going to wear to church? What will people think about me if they see me wearing the same clothing or hat which I wore last week?' These types of worries do not exist in the Aladura Churches.

10 Extempore (impromptu) prayers - African Initiated Churches are pacesetters in extempore (impromptu) prayers, compared to read prayers in the Mission Churches.

\section{Bibliography}

Ositelu, Rufus. 2000a. Leadership. Ogere: TCLAW Publications.

Ositelu, Rufus. 2000b. Practices and Observances of the Church of the Lord (Aladura) in the Light of the Old and New Testaments. Ogere: TCLAW Publications.

Ositelu, Rufus. 2002. African Instituted Churches: Diversities, Growth, Gifts, Spirituality and Ecumenical Understanding of African Initiated Churches. Hamburg: LIT.

Ositelu, Rufus. 2016. CHRISTIANITY: Inside Story from an African Perspective. Ogere: TCLAW Publications. 


\section{Part III}

Ghanaian perspectives 
$\Longrightarrow$ Taylor \& Francis Taylor \& Francis Group http://taylorandfrancis.com 


\title{
12 Distinguished church leader essay The Church of Pentecost and its role in Ghanaian society
}

\author{
Opoku Onyinah
}

\section{Introduction}

The emergence of the African Initiated Churches (AICs) signalled the new form of Christianity that was to take place on the continent of Africa. These churches attempted to operate independently, without any reference to the churches in the West. Those churches emerged alongside the classical Pentecostal Churches. While activities of the early AICs attracted much research in the mid-twentieth century onwards, very little was said about the contributions that these churches were making to their societies (Baëta 1962; Beckmann 1975; Parrinder 1953; Peel 1968; Turner 1967a, 1967b; Wyllie 1980).

However, until recently, little research had been done about the Pentecostals and the contributions that they were making in society. Current research, nevertheless, shows how Pentecostalism is growing and contributing in diverse ways to the development on the continent of Africa (Anderson 2004; Kalu 2008). One such church which is growing and respected is the Church of Pentecost $(\mathrm{CoP})$, with its headquarters in Ghana. While Kwabena Asamoah Gyadu, a Ghanaian theologian, argued that the $\mathrm{CoP}$ was a 'more respectable option in indigenous Pentecostalism' (Asamoah-Gyadu 2005, 89) in his study about independent indigenous Pentecostalism. Gerrie Ter Haar, a Dutch professor of religion, remarked that the CoP was one of the most successful of the African-led churches in Europe in her research about the relationship between African-led churches in Europe and churches in the home countries of Africa $(1998,174)$. Thus, I consider the invitation to the Church of Pentecost and some of the AICs to share some best practices and the roles they are playing in their societies as very important and relevant.

Consequently, this article will throw light on the role that the Church of Pentecost plays in Ghanaian society. It does this against the background of the Church of Pentecost in Ghana and its spread throughout the world. It continues by discussing the characteristics, structure and governance of the church. Then, it ends with the church's contribution to social services, development and its public role in the Ghanaian society. 


\section{The emergence of the Church of Pentecost}

The CoP traces its beginning to the activities of Pastor James and Mrs Sophia McKeown, both of Northern Ireland, who arrived in the then Gold Coast (now Ghana) in 1937, on the ticket of the Apostolic Church of the UK. The Apostolic Church had its origin in the Welsh revival and later rekindled by the Pentecostal faith after the Azusa Street revival. Peter Anim, who had heard of the Pentecostal faith, and his movement, the then Faith Tabernacle Church invited McKeown to assist them in Ghana. However, McKeown and Anim parted company in 1939 due to some theological differences.

Working in partnership with the indigenous converts and personnel, McKeown worked tirelessly to bring the Gospel of Jesus Christ to the country through his emphasis on the word of God, the transforming power of the Holy Spirit, and holy living. In 1953 McKeown was compelled to leave the Apostolic Church of the UK and get along with the indigenous people, under the name 'Ghana Apostolic Church', which was renamed the Church of Pentecost, in 1962. The church has become an indigenous church, with a good blend of Christianity and African cultural features. In the late 1950s, McKeown increasingly spent more time in Britain, spending only six months a year in Ghana. Thus, in 1982, when he retired, and handed over the chairmanship of the CoP to a Ghanaian, Apostle Fred Stephen Safo (1982-7), he knew that the church could run smoothly without him. The transition was very smooth. There have been four other African leaders after Safo. These are Prophet M. K. Yeboah (1988-98), Apostle Dr M. K. Ntumy (1998-2008), Apostle Prof. Opoku Onyinah (2008-18) and Apostle Eric Kwabena Nyamekye (elected in 2018); all followed smoothly without a conflict.

Giving credit to the role that James McKeown played in the CoP, E. Kinsley Larbi, a Ghanaian pioneer Pentecostal theologian observed

These principles [McKeown principles] helped to place the organisation on a sound footing morally, financially, and in terms of its strong and uncompromising evangelistic drive. These principles have since defined the ethos of the church. McKeown played the role of a facilitator par excellence.

$(2004,143)$

Allan Anderson argues that, 'To all intents and purposes this was an autochthonous Ghanaian church' $(2004,117)$. Thus, these scholars including Anderson, Teer Haar, Larbi and Asamoah-Gyadu set the $\mathrm{CoP}$ in place as an example of an African Pentecostal Church with respect; an African church that is selfsupporting, self-governing, self-propagating and self-theologising (Anderson 2004; Asamoah-Gyadu 2005; Larbi 2004; Teer Haar 1998).

The CoP has moved beyond the shores of Ghana to become a worldwide Christian denomination, now in 99 other countries. The spread of the CoP to other parts of Africa and the rest of the world in the beginning was not organised. As CoP members migrated along the coast of West Africa, they shared 
their faith with others and, before long, small groups of new converts were formed. These migrants sent information to the church's headquarters about the existence of the new churches they had established. The leadership responded quickly, by sending pastors as 'missionaries' to those foreign lands to care for them.

In a similar manner, when the Ghanaians immigrated to the West, they began to worship and contribute to the growth of western churches. Yet they could not find their identity. Consequently, some members of CoP among the migrants established churches in their places of abode. Thus, Roswith Gerloff, writing about the African-Americans rightly says that 'the religion of the slaves [Africans] and the religion of the slave master [whites] were never identical, even when both referred to the same Bible' $(1995,91)$. These churches established by immigrants who had not been trained as ministers show the effectiveness of oral culture. Hollenweger observes that 'all the elements of oral theology function as a logic system for passing on theological and social value information in oral society' (1985, 413-414).

At the end of 2017, the chairman of the CoP reported having 20,863 churches across the globe, with overall membership at 3,037,068. In 2017 alone, the church made inroads into eight new nations (Onyinah 2018, 28). While in most of the western countries the membership is mostly constituted of Ghanaians, in the other continents the membership is mostly indigenous. As of December 2017, the overall membership of the church in Ghana stood at $2,566,818$. This is approximately 9 per cent of the total estimated Ghanaian population of $29,088,849$ as of 31 December 2017 . This literally means that out of every 11 Ghanaians you meet, one would be a member of the CoP (Onyinah 2018, 32).

The overall growth analysis showed that $72 \%$ of CoP membership in Ghana was made up of children and youth (up to 35yrs). This is a healthy sign and an indication that The Church of Pentecost is a thriving church with a bright future. The gender analysis of the adult membership of the church indicated that females constituted the largest proportion of $62 \%$. It is interesting however, to note that whereas the female population in the church grew by $8 \%$ over the 2016 figure, the male population grew by an impressive $10 \%$.

(Onyinah 2018, 34, 45-46)

This was an indication that males were being attracted to the church.

\section{Characteristics of the Church of Pentecost}

\section{Doctrine and practices}

The CoP subscribes to almost all the fundamental doctrines of faith of the Apostolic Church and other classical Pentecostals. These are written in the 
constitution of the church and most of its documents such as baptismal certificates and the Ministers' Manual. The articles include the Bible, the one true God, human beings' depraved nature, the Saviour, repentance, justification and sanctification. Others are the ordinances of baptism and the Lord's Supper, baptism, gifts and fruit of the Holy Spirit, afterlife, tithes and offering and divine healing ((Church of Pentecost 2016, 7-9) Hollenweger 1972, 291-456; Worsfold 1991, 96-102).

The Apostolic Church was a church that displayed all the spectrum of classical Pentecostalism. The Dean of Pentecostal studies Walter Hollenweger describes the Apostolic Church as a church that 'gives greater play to the gifts of the Spirit' $(1972,192)$. In the CoP, as with the Apostolic Church, men are called to be apostles, prophets, evangelists, pastors and teachers. Others are called to the offices of elders and deacons. Women are called as deaconesses and not ordained into the full-time pastoral ministry. Besides, the Apostolic Church held to an ethical rigorism, the prohibition of things such as drinking alcohol and smoking. Members who were found making a practice of going to places which were considered questionable, such as to the cinema and concert shows and falling into open sin were to be disciplined (Apostolic Church 1937, 35-44, 238-239; Hollenweger 1972). The CoP followed similar practices.

The CoP places emphasis on the role of the Holy Spirit in one's life and encourages all its members to experience what the Pentecostals call the baptism of the Holy Spirit. The role of the Holy Spirit and power in the CoP go beyond what Cyril Eastwood attempts to identify as the priesthood of all believers (1960, 260-262). The role of the Holy Spirit is associated with what Roger Stronstad explains as the prophethood of all believers (1999, 115-114), where all could become powerful and confront witchcraft and fetishism in their evangelistic activities. This sort of 'prophethood' of all believers appeals to the peasants and downtrodden who constitute a majority of the Ghanaian population. They help to propagate the gospel. The rapid growth of the CoP is evidence of this.

\section{Structure and government}

The church's headquarters is in Ghana. The church has a centralised structure that is similar to the Apostolic Church in the UK (Apostolic Church 1937; Church of Pentecost 2016).

At the top of the church's structure is the General Council which consists of all confirmed ministers of the church, area executive committee members, chairmen of boards and committees and ministries directors. Below the General Council is the 15-man Executive Council that sees to the administration of the church. The area (and national) presbyteries, chaired by apostles and prophets, come below the Executive Council. Under the area presbyteries, are the district presbyteries. The district presbyteries are headed by pastors. At the bottom of the administrative structure of the church are the local presbyteries, headed by presiding elders. 
Besides the local churches, districts and areas are the ministries and boards, which are headed by directors who report to the General Council through the Executive Council. These ministries are women, evangelism, children, men and youth. Some major boards and committees in the CoP are the finance board, Pentecost social services board, ministerial committee, pension board, estate committee and the missions board. The missions board falls under the international missions' director, who is directly accountable to the chairman of the church, on the same level as the church's general secretary. The structure may have its weaknesses, as with all structures. However, on the whole, it seems to fit in with the Ghanaian culture, especially that of the Akan with its various military organs (Busia 1951, 1-22; Nukunya 1992, 67-74). Thus, it makes the members feel secure in its formality, accountability and disciplinary measures.

\section{Worship}

Worship in the church is similar to other classical Pentecostals (Hollenweger 1972, 140, 149), with some cultural diversities. These diversities are portrayed in activities such as the giving of testimonies, praises, special times of prayer called worship, and preaching. There is the opportunity to express oneself before God in diverse ways - prayer, dancing, testimonies and local theologisation. An example of such local theologisation is the example of Afua Kuma whose application of the appellations of chiefs to God has become a classical example of local theologising within African theology (Bediako 1995, 59-60; Kumah 1981). Eventually the church developed a form of worship, especially its songs that have had an impact on Ghanaian society (Larbi 2001; Leonard 1989; Hackett 1998). Often as preaching and prayer go on, a member would receive through the inspiration of the Holy Spirit a song that would be sung spontaneously, without having to write it. Professor Emmanuel Larbi observes that the CoP 'has bequeathed to Ghanaian Christianity more locally brewed Christian songs than any other Church in the country' $(2004,143)$.

\section{Training}

Until 1971 there was no formal training for any of the church's officers. Retreats for teaching and prayer were held from time to time by an area head for pastors, their wives, deacons and deaconesses in the area. It was Pastor David Mills, the Elim missionary who was adjoined to the CoP, who reintroduced Bible school to the CoP in 1972. The Bible school concept had been introduced to the church in 1953 when the Latter Rain visited Ghana, but it was abandoned in 1957 (McKeown 1957). The Bible school headed by Pastor Mills was also closed down in 1975 and reopened in 1981. It is clear from the closing down of the schools that, in time past, the CoP shared with other Pentecostals, as Hollenweger points out, that 'modern academic theology is a tragedy, whose fruit is empty churches' $(1972,194)$. As with other Pentecostals, the situation has changed significantly. Currently the CoP has established a University College 
which has three faculties: theology and missions; business administration and information technology. The infrastructure of the Pentecost University College was provided by the CoP. It also has a theological seminary which trains its ministers. Full-time ministers spend at least one academic year, training at the Pentecost Theological Seminary, and one other year by extension. Some continue to bachelor's-degree level, others to master's level and still others go as far as to doctoral level.

\section{Finance}

On finance, it is the policy of the $\mathrm{CoP}$ to be self-supporting. The main sources of income are tithes and offerings contributed willingly by the members. The church believes that God will meet the church's financial needs in season and out of season. From this viewpoint, the church uses whatever local resources are available for its projects. Church members have been supporting the church financially by faithfully paying their tithes and giving generously in several areas, including the putting up of church buildings, mission houses, clinics, school building, and purchasing of vehicles and evangelism equipment.

In terms of structure, there is a finance board which administers the central fund of the church. Among other things the board prepares and submits annual budget and financial reports to the General Council through the Executive Council. Furthermore, it also ensures that an effective audit system is maintained at the head office and other branch offices of the church and submits its annual financial reports to external auditors before the General Council meetings. There is also an auditing, monitoring and evaluation department which conducts an annual full-scale auditing, monitoring and evaluation of church finances, projects and activities which go on within the year. The department also audits pastors who go on transfer or retirement. The focus for the exercise is to check the extent of compliance with the church's guidelines and financial policies and ascertain whether the church's funds have been judiciously applied. The department reports to the chairman of the church, who together with the Executive Council will discipline people who flout the policies. This instils discipline and order in the church, and gives church members the assurance that the money given to the church is used for the right purposes and encourages members to give more.

\section{Social services}

Right from the beginning, McKeown wanted the church to be indigenous with Ghanaian culture, ministry and finance. He realised that

it would be difficult to grow an 'English oak' in Ghana. A local 'species', at home in its culture, should grow, reproduce and spread: a church with foreign roots was more likely to struggle. 
His aim was to sow what he called the 'local species' to produce an indigenous church. To achieve this goal of indigenisation, McKeown's philosophy was 'just to evangelize' (Debrunner 1967, 325) and make the people know God. He said, 'once we have a strong church of people who really know Jesus and the Holy Spirit, then everything else will follow' (Leonard 1989, 72). The implication of this was that he was not going to concern himself and the church with the provision of social services. The people who knew God were going to provide finance, build schools, hospitals and serve their nation in diverse ways. On the face value, this was quite strange. A church is supposed not only to serve the spiritual needs of people, but also attend to their social needs. Nevertheless, the philosophy behind McKeown's policy was that he could not offer the people what he did not have. At the time, he did not have money. He would give them what he had. Once he got the right people, they would serve their own people with other needs. History was to judge him.

In 1982, during the chairmanship of Safo, the church set up a department, called Pentecost Social Services (PENTSOS). Its vision was to serve the spiritual and physical needs of people through a holistic approach to development on a sustainable basis. PENTSOS has been progressive in its vision. The chairman of the church reported in the 2018 State of Church Address that by the close of December 2017, the church had eight health institutions, one hospital and seven clinics. The total outpatients' department attendance in the church's eight health institutions in 2017 alone was 194,995. Altogether, a total of 17,682 admissions and 4,987 deliveries were recorded during 2017. The church currently runs 84 basic schools, three vocational schools, two senior high schools and a university college. The head office and the areas continue to sponsor needy student members at the tertiary level under the Pentecost Educational Scholarship Scheme. The church also operates a credit union called Pentecost Co-operative Mutual Support and Social Service Society Ltd (PENCO). The objective of these microcredit schemes is to provide financial empowerment to people to operate viable and productive businesses. A total of 40 credit unions which operated in 34 church areas were supervised by PENCO Apex in 2017.

Some of the church's social activities are done in collaboration with various institutions. One such institution is the Widows Ministry at Bolgatanga; a ministry which seeks to assist widows to get petty jobs to enhance their livelihood in the less endowed areas in the Upper East Region of Ghana. Others include a mental health authority, orphanages such as Countryside Children Welfare Home, Ghana Health Foundation and Physically Challenged Action Foundation, Royal Sparrows Ministry of Blind People and Kwame Nkrumah University of Science and Technology Chaplaincy Council. The humanitarian interventions done by the church (also by the districts and areas) include donations to hospitals, prisons, provision of relief items to individuals affected by natural disasters, registering the aged and other needy people on the National Health Insurance Scheme. Furthermore, the church runs a convention centre called Pentecost Convention Centre, which is opened to the public for its usage. 
In 2017, a total of 75,163 guests made up of churches, Christian organisations, private organisations, government agencies, banks, and individuals lodged at the centre during various programmes. Out of the 75,163 guests, the church's programmes comprised 50.1 per cent while the others comprised 49.9 per cent.

\section{Fellowships/fraternities/para-church organisations}

The CoP shares fellowship and support the activities of para-church organisations both within and outside the country. The church has maintained the status as the highest financial contributor to the Ghana Pentecostal and Charismatic Council (GPCC), Ghana Institute of Linguistics, Literacy and Bible Translation, Bible Society of Ghana and the Ghana Evangelism Committee (GEC) for several years (Onyinah 2018). Many other para-church, state and some non-governmental organisations also receive appreciable financial and logistical support from the church. These include the Scripture Union (SU) and Child Evangelism Fellowship. Other organisations include Ghana Prisons Service Chaplaincy Unit, African Forum on Religion and Government, Theovision International, Gideon International, African Enterprise, and Reach the People Ministries. Others include the Lausanne Movement, Pentecostal World Fellowship and Bible League.

\section{Public roles}

The impact of the $\mathrm{CoP}$ in the socioeconomic development of the nation can also be felt in other areas as follows: The church, through its social services outfit provides employment for many people to complement government's efforts. The church has five ministers serving commendably well in the Ghana armed forces and the prisons service. The church has also put up a police barracks for the government. The church, on its own, and through its active involvement in the activities of institutions, such as Ghana National Peace Council, GEC, GPCC and its collaboration with the Christian Council of Ghana plays a significant role in seeking the peace and stability of the nation. This is done through advocacy, prayers and the provision of godly counsel to the members and others whenever called upon or the need arises. For example, the church in Ghana has been involved in HIV and AIDS education through its collaborative efforts with the Ghana AIDS Commission. Others include educating people on succession and drafting of wills. In many cases, widows have been robbed of or denied their inheritance in society due to lack of knowledge.

The government in Ghana as well as some civil society organisations have been tapping the potentials of some members and put them in places of important leadership positions such as Bank of Ghana, the Public Interest and Accountability Committee (PIAC) and large state publications. For example, Mrs Angela Peasah served meritoriously for two terms on the PIAC; this is the committee that regulates the use of proceeds from Ghana's petroleum revenues. 
Elder Professor Kwame Boasiako Omane-Antwi, current Vice Rector of the Pentecost University College (PUC) was appointed as Board Chairman of the New Times Corporation. His two-year tenure saw the turning around of the fortunes of the newspaper. At the end of his term, he was personally invited by the President, John Dramani Mahama to be congratulated and asked to be appointed to the largest state publication the Daily Graphic, a position he still occupies.

The chieftaincy institution is still the custodian of Ghanaian cultures. The church occasionally organises conferences for Christian royals, chiefs and queens, with the aim to influence the traditional worldview of the chieftaincy institution to do away with archaic practices, get involved in the development of their communities and ultimately make Christ the Lord over their respective rulership. Similarly, periodic conferences are organised for Christian politicians and chief executives with the aim to help them put in place good and godly governance practices and administration.

The Youth Christian Political chamber has been established to train young people who are interested in politics to get into it with the motive to serve the Lord and the nation with integrity. They are encouraged to join any political party of their interest and impact them. Taking into consideration the best practices of the developments within the CoP, the government of Ghana has begun a dialogue with some selected churches as a pilot to begin partnership with churches under the government's 'One District One Factory' initiative. This initiative is a government programme aimed at establishing at least one medium-to-large-scale factory in each of the 216 administrative districts in the country. These medium-to-large-scale enterprises are expected to have the potential to significantly enhance the economies of the districts including creation of jobs, stable income for the residents and improved livelihoods.

\section{Social needs in the external branches}

On the international level, the church responds to the social needs of the people. Both van Dijk and Ter Haar rightly observe that members automatically become part of 'a supportive socio-religious network', which helps them to define their roles in their various respective societies (Ter Haar 1995, 17; van Dijk 1992, 1-25). The meeting places become places of providing information on some issues such as jobs and accommodation. Professionals among members, including council workers, educationists, teachers and solicitors, become consultants in their areas of speciality and render services to their clients on voluntary basis. For example, those without resident permits are advised to apply for permits or go home rather than to live in a country without legal documents. Thus, here the church provides conditions for migrants of insecure states, often with no jobs, no houses, no money and no legal documents to find their right places in society.

Concern for the social needs of the members is also apparent, in seeking the general welfare of the members, such as in marriages and funerals. Those whose 
spouses are not with them are counselled. In many instances the conditions that brought such immigrants, did not permit them to bring their dependants. Most marriages have broken down because of the long separations of spouses in search of greener pastures. For those who want to get married, the church helps them through its international network. In line with the various Ghanaian cultures, the church officers in Ghana as well as those abroad make investigations into the prospective spouse. The purpose is to find out and ensure that the potential spouse is not a noted criminal, not given to quarrelling, and is hard working with good morals and reputation. After both parties are satisfied, they communicate to each other, and then those at home eventually help to perform the customary rites. Thus, here the church takes over the role of the traditional abusua (family). By these services, the church creates conditions which help the immigrants to get well established in their family lives, and by so doing help to arrest unforeseeable marital problems and their repercussions, including separation and divorce.

Regarding funerals, donations are collected for the bereaved. Thus, here the church helps to alleviate the possibility of incurring debt, pressure and 'guilt and shame' from its members. For Ghanaians, funerals are very important. Although the church discourages expensive funerals, immigrants may fly home for the funerals of their parents, uncles, nephews or siblings and thus incur debt. Those who fail to go usually send money for this purpose. Whether a bereaved person is able to attend a funeral at home or not, the church allows another funeral to be celebrated abroad. Donations are made to the individuals concerned towards their funeral expenses.

The church's emphasis on the concept of holiness (Ter Haar 1998, 225), which may be considered by some as fundamentalism (Hollenweger 1972, 50-52), helps to protect vulnerable immigrants from falling victim to social problems. Members are encouraged not to be addicted to smoking, alcohol or drugs. Instead their bodies should be given to the Holy Spirit as the Temple of God. Accordingly, the church prevents its members from falling victim to crimes, such as drug abuse, drug trafficking, excessive use of alcohol and other petty crimes.

The missionaries provide counselling for members especially in areas of marital problems, employment, need for legal papers, finance and dreams believed to have been influenced by demons. That some of these counselling sessions have been very beneficial and helpful to the immigrants is indicated in the ways and manners in which many people seek the attention of pastors.

\section{Conclusion}

The emergence, growth and development of the $\mathrm{CoP}$ in Ghana and elsewhere is a reminiscence of a new era of African Christianity, where African Initiated Churches contribute to national development through their self-supporting efforts. Although much had been said about this aspect of the AICs, this chapter has shown that some meaningful contributions are being made to enhance not 
only the spiritual needs of the people but holistic aspects of both personal and societal development including empowerment, good governance, poverty alleviation and accountability. The overseas churches have been shown to help to create the necessary conditions for their members to acquire a sustainable position in the various societies where they find themselves, assisting their social responsibilities and by that, link them to families at home as well as satisfying their spiritual needs. This is part of what the power of Pentecost has done on the soil of Africa and all over the world.

\section{References}

Anderson, Allan. 2004. An Introduction to Pentecostalism. Cambridge University Press.

Apostolic Church. 1937. The Apostolic Church: Its Principles and Practices. Bradford: Apostolic Publications.

Asamoah-Gyadu, J. Kwabena. 2005. African Charismatics: Current Development within Independent Indigenous Pentecostalism in Ghana. Leiden: Brill.

Baëta, C. G. Kwami. 1962. Prophetism in Ghana: A Study of 'Spiritual' Churches. SCM Press Ltd.

Beckmann, David M. 1975. Eden Revival: Spiritual Churches in Ghana. London: Concordia Publishing House.

Bediako, Kwame. 1995. Christianity in Ghana: The Renewal of a Non-Western Religion. Edinburgh: Orbis Book.

Busia, Kofi Abrefa. 1951. The Position of the Chief in Modern Asante. Oxford University Press.

Church of Pentecost. 2016. The Constitution of the Church of Pentecost. Accra: The Church of Pentecost.

Debrunner, Hans Werner. 1967. A History of Christianity in Ghana. Waterville Pub. House.

Eastwood, Cyril. 1960. The Priesthood of All Believers: An Examination of the Doctrine from the Reformation to the Present Day. London: The Epworth Press.

Gerloff, Roswith I. H. 1995. 'The Holy Spirit and the African Diaspora: Spiritual, Cultural and Social Roots of Black Pentecostal Churches.' EPTA Bulletin 14, no. 1:85-100.

Hackett, Rosalind I. J. 1998. 'Charismatic/Pentecostal Appropriation of Media Technologies in Nigeria and Ghana.' Journal of Religion in Africa 27, no. 3. (August): 258-277.

Hollenweger, Walter J. 1972. The Pentecostals. London: SCM Press Ltd.

Hollenweger, Walter J. 1985, 'After Twenty Years Research on Pentecostalism,' Inter Notional Review of Mission LXXV, no. 297:10-11.

Kalu, Ogbu. 2008. African Pentecostalism. Oxford University Press.

Kumah, Afua. 1981. Jesus of the Deep Forest. Translated by J. Kirby. Accra: Asempa Publishers.

Larbi, E. Kingsley. 2001. Pentecostalism. The Eddies of Ghanaian Christianity. Accra: CPCS.

Larbi, E. Kingsley. 2004. 'Sustaining the Growth.' In James McKeown Memorial Lectures: 50 Years of the Church of Pentecost, edited by Opoku Onyinah. Accra: The Church of Pentecost.

Leonard, Christine. 1989. A Giant in Ghana: 3000 Churches in 50 Years - The Story of James McKeown and the Church of Pentecost. Chichester: New Wine Press.

McKeown, James. Circular letter, 29 November, 1957.

Nukunya, G. K. 1992. Tradition and Change in Ghana. Accra: Ghana Universities Press. 


\section{Opoku Onyinah}

Onyinah, Opoku. 2018. 'The State of the Church Address.' In The Church of Pentecost: 43rd General Council Meetings. Accra: Pentecost Press Ltd.

Parrinder, Geoffrey. 1953. Religion in an African City. Oxford University Press.

Peel, J. D. Y. 1968. Aladura: A Religious Movement Among the Yoruba. Oxford University Press.

Stronstad, Roger. 1999. The Prophethood of All Believers: A Study in Luke's Charismatic Theology. Sheffield Academic Press.

Ter Haar, Gerrie. 1995. 'Strangers in the Promised Land: African Christians in Europe.' Exchange 24, no. 1: 1-24.

Ter Haar, Gerrie. 1998. Halfway to Paradise: African Christians in Europe. Cardiff Academic Press.

Turner, Harold W. 1967a. History of an African Independent Church II: The Life and Faith of the Church of the Lord (Aladura). Oxford: Clarendon Press.

Turner, Harold W. 1967b. History of an African Independent Church I: The Church of the Lord (Aladura). Oxford: Clarendon Press.

van Dijk, Rijk A. 1992. 'From Camp to Encompassment: Discourses of Transsubjectivity in the Ghanaian Pentecostal Diaspora.' Journal of Religion in Africa 26, no. 4. (January): 1-25.

Worsfold, James Evans. 1991. The Origins of the Apostolic Church in Great Britain: With a Breviate of its Early Missionary Endeavours. Wellington: Julian Literature Trust.

Wyllie, Robert W. 1980. Spiritism in Ghana: A Study of New Religious Movements. Missoula, MT: Scholars Press. 


\title{
13 An evaluation of Pentecostal Churches as agents of sustainable development in Africa
}

\author{
The case of the Church of Pentecost
}

\author{
Emmanuel Kwesi Anim
}

\section{Introduction}

The term development comes with some nuances, it is sometimes loaded with past meanings, some of which are not positive. Some think of development as material change or social change in the material world. Others understand the term to mean westernisation or modernisation and the underlying factor is associated with having more things (Myers 1999, 3). Myers talks of transformational development to mean an action or process whereby one seeks positive change in the whole of human life materially, socially and spiritually, while the adjective transformational is a reminder that human progress is not inevitable but requires hard work and depends on the choices that we make. It is against this background that I see that sustainable development provides us with a more detailed and comprehensive framework for addressing the human condition. We understand sustainable development as economic development that is conducted without depletion of the natural resources. In other words when we talk of sustainable development, we mean transformational and responsible development. It is a situation where development meets the needs of the present without compromising or limiting the ability of future generations to meet their own needs.

Recent discussions have focused on the Sustainable Development Goals (SDGs). At the core of the SDGs is a fight against extreme poverty, inequality and injustice and to address the challenge of climate change. That the set goals are interconnected is a stark reminder that we live in a global village where artificial boundaries no longer define our sense of identity and common destiny. The success of one goal often requires tackling issues more commonly associated with another. This understanding inspires a sense of collective responsibility, the spirit of partnership and pragmatism in the working together of all stakeholders. Recent developments in science and technology and frequent movements of information, people and other resources across boarders means that new emphasis should be placed on our common and shared humanity

\section{Values-based development and religious communities}

It is said that over 80 per cent of the global population has some affiliation with religious communities (BMZ 2016, 8). Religious communities have often 
contributed to the provision of services such as medical, education, agriculture and other essential services like water to people across the world and particularly in Africa. Many NGOs such as the World Vision and Tear Fund make considerable contributions to the individual and community in relief and development, as do other faith-based institutions and organisations. It has been observed that in some countries in sub-Saharan Africa, religious communities provide more than 50 per cent of all social services (BMZ 2016, 8). Religion brings people together; however, it has the potential to disrupt the peace and stability of society. Therefore, the need to strengthen the potential that religion can bring to society cannot be overemphasised. Similarly, creating appropriate awareness and tolerance among religious groups can strengthen the potential that religion can offer for development, particularly in Africa.

In his introduction to Religious Communities as Partners for Development Cooperation (BMZ 2016) Gerd Müller, German Federal Minister for Economic Cooperation and Development, highlights some important virtues that flow out of religious communities. Faith communities have often played significant roles in helping the poor and vulnerable and the marginalised in society. The act of compassion in many cases defines religious communities. As we hear of Mother Theresa of Calcutta so we can also talk of Rev. Fr Andrew Campbell, the Irish Catholic priest who has been working in Ghana for many years and founder of the Weija Leprosarium in Accra, where many lepers, some of whom have been abandoned by their families, are given a home, food and medical care. 'A values-based development policy means that we take the contribution of religion seriously, engage with religious actors and seek to find common answers to hunger, misery and injustice' (BMZ 2016, 5). It is an admissible fact that it would be nearly impossible to achieve the Agenda 2030 unless the religious communities are active partners in this process. This is also the case knowing that 'religion is a defining factor for most people's view of the world, their lifestyles and their civic engagements. It continues to have a strong influence on political and social life' (BMZ 2016, 11-12).

In many developing countries, people have more confidence in religious leaders than in their political leaders. As a result, religious institutions are often the first place people turn to in an emergency. Religion can strengthen the resilience of individuals and entire societies because it offers explanations and rituals that help people deal with loss, suffering, failure and disaster.

Religion can give people a sense of identity and bring people together in the same way that it can also be used to exclude people. Religion can also be exploited in order to safeguard one's position of power, suppress critical voices and avoid democratic reforms.

(BMZ 2016, 12)

\section{The myth of development in Africa}

The pursuits of independence for Africa were marked by two assumptions. First, that the land was endowed with abundant natural resources to sustain its people; 
and, second, the leaders were capable of managing their own resources for the benefit of the African people. This may be argued against the backdrop of enormous natural and mineral resources available on the continent. But such hope and aspiration soon disappeared as African states came to be described as 'vampire states' where the state, which was meant to be the 'mechanism for the pursuit of public benefit' became 'an instrument of exploitation, managed purely in the interest of those who held power' (Gifford 1998, 12). This analysis, however, does not lend itself to other external factors such as imbalances in international trade often in favour of western nations.

Most African independence coincided with the period of the Cold War - the battle of ideologies of politics and development. Many African leaders such as Kwame Nkrumah of Ghana, Kenneth Kaunda of Zambia, Jomo Kenyatta of Kenya, Haile Sellassie of Ethiopia, Julius Nyereyere of Tanzania and Ahmed Sékou Touré of Guinea among others, sought to fashion an African unity, which would consolidate Africa's resources and compete with the rest of the world. Thus, Kwame Nkrumah, the first prime minister of Ghana, on 6 March 1957 when Ghana attained independence remarked that 'the independence of Ghana is meaningless unless it is linked to the total liberation of the whole African continent'. However, the lack of national unity, social controls and organisational capacities on the part of most African states undermined sustainable growth of their development.

Many post-independence African countries tied their politics and economies to their colonial roots mainly in the West in different variations, while others looked to the communist East for political and economic ideologies. This orientation meant that independent African states indirectly joined the battle of the Cold War. Between the 1970s and early 1980s, African leaders who looked to the East and were inspired by Marxist ideology advocated a revolution to overthrow both the imperial apparatus and the African elite in government who were considered parasitic and corrupt. Military coups and dictatorship became the order of the day and it turned out to be the means by which the poor enriched themselves. For example, the most popular Nkrumah government in Ghana was overthrown in a military coup in 1966, since it was authoritarian, corrupt and had no regard for the rule of law. Nkrumah was seen to have embraced socialist ideals and a personality cult was built around him. This situation became enough justification for his removal from office by the military. Gifford observes that, 'the military handed over to Kofi Busia's Second Republic (1969-1972), which ended with another coup. During the ensuing years of rule by a corrupt Military Council, particularly under General Ignatius Acheampong (1972-1978), Ghana bordered on collapse' (2004, 2). It is disturbing to note that the Acheampong's military government was also toppled in yet another military coup on 4 June 1979, led by Flight-Lieutenant John Jerry Rawlings who also claimed corruption of the military elite as justification for his actions. Upon assumption of power, Armed Forces Revolutionary Council led by Jerry Rawlings executed in public eight senior military officers including three former heads of state on 16 and 26 of June 1979. It was observed that 'the popular 
mood included a good deal of envy and anger against those who were thought to have enriched themselves at the expense of the masses' (Gifford 2004, 1).

By the close of the 1980s, and after the fall of communism, most African leaders were beginning to change their perspective and turned to the West. Here, the International Monetary Fund (IMF) and the World Bank became significant. Various attempts were made to address Africa's development needs through different economic models or theories.

Gifford (1998) aptly explains that around the time of Africa's independence in the 1960s, modernisation theory was thought to hold the answer to Africa's economic needs as it would transform Third World countries into participative, pluralist and democratic regimes. The state and the ruling elite were considered to be the primary agent of political and economic development and the principal bearers of modernisation. Development was conceived as centre-outward and top downwards process. This model was inspired by a similar one which had been experimented in Latin America in the 1950s. The euphoria of modernisation theory was short-lived when it was observed that modernising elites were parasitic and serving their own and foreign interests and not that of their people (Gifford 1998). World trade was perpetuating structures of underdevelopment and not removing them. Modernisation is used to explain the socioeconomic and political process that a nation goes through when it transforms from a traditional society to a modern one. The theory works on the assumption that as nations develop, economic development and social change would lead to democracy. This theory is often attributed to American social scientists in the 1950s based upon Rostow's stages of development. Here it is believed that social mobilisation would cause individuals and societal groups to change their aspirations which would eventually lead to economic development (Rostow 1990). The modernisation model was subsequently replaced by the dependency model in the 1970s. Dependency theory, which became popular in the 1960s is based on a Marxists analysis of the world, which sees globalisation in its manifestation of market capitalism as perpetuating exploitation of cheap labour and resources in the developing countries in return for obsolete technologies of the West. The dependency theory argues for an 'inward-looking' approach to development and an increased role for the state in terms of imposing restrictions to trade and promoting nationalisation of key industries. However, the inability of African states to properly manage the economic affairs of the nations as a result of endemic corruption, had made this economic model unsuccessful.

The 1980s saw the introduction of the Economic Recovery Programme (ERP) which aimed at resuscitating Africa's economy by reducing inflation to achieve equilibrium. The process sought to promote economic growth and export recovery through a realignment of incentives towards productive activities. However, the dependency model was seen as even more disruptive than the modernisation model. It was believed that at the time of independence, power had been given to the wrong people. Africa's corrupt elite and their selfseeking policies were responsible for the problems in Africa. 
The new realism model was introduced in the latter part of the 1990s. The theory behind this model was a call for structural adjustment in the economies of the Third World countries. The idea was promoted mainly by the World Bank, the IMF and American policy-oriented academics. It was the theory behind the New Realism that introduced the Structural Adjustment Programme (SAP). The SAP required cuts in government expenditure, and this meant in practice, the withdrawal of government subsidies from health services, agriculture, education and utility services such as electricity and water supply (Gifford 1998).

The government of Ghana in 1995 prepared a long-term national development framework with the view of accelerating social and economic development within a reasonable period of 25 years. This was known as 'Vision 2020', and would be rolled out in phases of five years.

The basic assumption underlying the preparation of this plan was that a partial foundation had been established by the ERP for the long-term economic and social development; but the foundation needed to be strengthened to ensure more rapid growth in the future to enable Ghana to join the ranks of middle-income countries.

(Asante and Owusu 2013, 3)

In all these theories and related programmes, the assumption was that productivity would increase through capacity building of human resources. Agriculture and industry would generate wealth which would eventually trickle down to the masses. But these laudable ideas were only to remain a dream. In 2002, Ghana had to apply for the Heavily Indebted Poor Countries (HIPC) initiative in order to survive rather difficult macroeconomic conditions. The inflation rate was 'about 40.5 per cent (instead of the 8 per cent anticipated in 2000), and exchange rate depreciation of about 49.8 per cent [against the US dollar] (instead of the 6 per cent targeted in 2000)' (Asante and Owusu 2013, 6). The HIPC initiative, although humiliating for a sovereign nation, as its credit rating was downgraded, was also an attempt by government to reduce its debt burden and have easy access to more external resources for accelerated poverty reduction. HIPC was administered by the World Bank and the IMF. For a good analysis of post-independence Africa's social, economic and political development, see Gifford (1998, 1-56), also Asante and Owusu (2013, 1-24).

Various reasons may account for the reason why development models fail in Africa, and some of these tend to be ignored by local governments and western policymakers on Africa's economic development. Here, I would like to consider the key ones. The first is the primal worldview and mentalities towards wealth acquisition. Our best analysis comes from G. M. Foster. In his book, Traditional Societies and Technological Change, Foster argues that 'animistic $^{11}$ worldview, determines that resources are limited just like a piece of cake. Therefore, by implication, the size of one's wealth is at the expense of another who may have very little or nothing. Foster explains this as 'the concept of the limited good'. In response, the rich sometimes conceal their wealth for 
fear of being accused of selfishness and using malicious means such as witchcraft in acquiring wealth. As a result, those who are wealthy or have the money to start projects become reluctant to do so particularly within their immediate communities or hometowns.

The next factor is ritual taboos and land tenure systems. Sometimes development projects are put on hold because local people believe that the gods may not be happy with them. For example, there have been cases where road constructions to important places for economic reasons had to be abandoned. Some days are classified as 'Sabbath' and would be a taboo if people went to the farm, sea or rivers on such days for economic activity. In some situations, a six-week traditional ban on noise making by the local chiefs prior to major annual festivals such as Odwira and Homowo celebrated by some Akan groups and the Gas, respectively, could mean that no social or economic activity which involves noise making could go on. These traditional customs have brought conflicts between social groups such as the church and local chiefs and their people leading to adverse effect on economic activities and development. For example, in the last two decades there have been several confrontations between the Ga traditional council and some Pentecostal and Charismatic Churches in the Greater Accra Region, leading to the destruction of church musical instruments and injuring some church members. In seeking a lasting solution, the Accra Metropolitan Assemblies issued the following directives:

During the period of the ban, the usual form of worship should be confined to the premises of churches/mosques and noise levels be minimized to the barest limits possible ... the positioning of loudspeakers outside the premises of churches, mosques and pubs are banned. Roadside evangelists are to cease their activities during this period. Apart from an identifiable task force which consists of AMA personnel, the Police Service and Representatives from the Traditional Councils with tags, no other person or group of persons should be seen or found enforcing the abatement of noise in the metropolis. ${ }^{2}$

\section{Frequent military coups and dictatorship}

Frequent military interventions have proved more of a liability than anything else in dealing with Africa's development problems. Very often, the military has been more corrupt and had to spend a great deal of state money in arms to keep its position in power. Ghana, for example, from the time of independence from the British in 1957 to 1992, had witnessed not less than five military interventions in government and many other failed ones. The situation is not particularly different in Nigeria, Liberia, Sierra Leone and Burkina Faso to name but a few. Once a country slides into military regime, many investors particularly those from the West withdraw their funding and so much of state funds are used to acquire arms at the expense of productive economic ventures and social infrastructure such as schools and hospitals. 


\section{Nepotism, bribery and corruption}

It is observed that African states were from the beginning essentially an agency for control and extraction of resources (Gifford 1998, 4). The partitioning of Africa into numerous states along colonial lines was perceived as an instrument of the West to take control of African resources for the benefit of the western nations (Davidson 2005). Africans therefore saw the statement machinery as a tool of the colonial master and therefore saw no reason to be committed to the public institutions. The local parlance in Ghana is that, 'you don't carry the government work on your shoulders, you drag it on the floor' meaning one should not toil for the work of the government or the state. This makes African states quite different from the western states in terms of shared values between state and society. Gifford argues that

colonial administrations were both centralized and authoritarian. Just as important, the rulers manifested a sense of superiority over those they ruled, and power was experienced as coming from above rather than below. Thus the ruled developed a sense of the state as an alien institution, to be feared but also to be deceived and exploited, since it existed on a plane above the people whom it governed, beyond any change of control.

In western societies, power is exercised through legally defined structures for a publicly acknowledged aim. Officials who exercise the powers of office treat other individuals impersonally, according to the criteria which the structures demand. Successive officials would act the same, and respect the rules of the office. This has been the way of running complex modern state. In many respects, one may argue that African states have performed badly in adopting this rational-legal mode of organising a state and shared resources. African governments and other public leaders tend to run the state on a system of kinship and loyalty, which encourages cronyism and nepotism (Gifford 1998, 5). This is the means by which leaders consolidate their grip on power and the loyal subordinates feel secure and protected and resources are channelled between these lines.

Following Max Weber (1976), Gifford aptly observes that this system is based on the kind of authority a father has over his children. Those on the lower ranks of business are not subordinate officials with well-defined powers and functions but retainers whose position depends on a leader to whom they owe allegiance (Gifford 1998, 5). For many Africans, having the privilege to serve in a public office is also a privilege to maximise one's personal fortunes at the expense of the shared resources of the state.

If corruption is defined as the use of public office to achieve private goals, then corruption simply does not make sense in many societies in Africa where there is no separation between public and private lives in peoples' minds, and personal and official lines of duty. Public office is often seen as the route to 
personal wealth and power as the popular African maxim goes, 'the goat eats where it is tethered'. This is the reality that confronts many African states and any credible analysis of African development cannot ignore these unfortunate situations.

\section{Ghana in context}

Ghana has enjoyed a relatively stable society since the country returned to constitutional rule in 1992. However, persistent trade imbalance, high inflation and corruption have bedevilled the nation in recent years. The hold-up of the results of the 2012 general elections which was contested in court by the main opposition party the National Patriotic Party (NPP), went on for the best part of eight months (December 2012-August 2013). The situation contributed to a major depreciation of the cedi against major trading currencies as investors began to move their investment to other neighbouring countries. The economic situation was also aggravated by a prolonged shortage of electrical power to feed the industries and other businesses. This also meant that there were less resources available to government to undertake development projects and to support education and health services. The National Health Insurance, introduced by the previous government led by Mr John Agyekum Kuffour was at risk of collapsing. Inadequate medicine in the hospitals forced government to withdraw allowances for teachers and nurses in training which had existed for several years.

It has recently been reported that malaria is the leading cause of deaths in Ghana and on average three children die every day as a result of malaria, while $\$ 6.6$ million is lost to loss of productive hours as a result of malaria and related illnesses. The recent illegal mining known as 'galamsey' continues to destroy the nation's major rivers which provide drinking water as well as support aquatic life and maintain balance in the ecology. A recent report indicated over $\$ 6$ million was lost to the government in the year 2017 as a result of illegal mining which is now being championed by Chinese immigrants in the country. The government's decision to ban all forms of small scale and illegal mining has not been easy to implement as pockets of persons and companies continue with the practice underground. However, there is every reason to hope for the better and the recent change in government with an unprecedented majority in favour of the NPP government opens new opportunities for development as the new government has activated its manifesto to provide free education to all citizens up to the secondary level. Allowances for trainee nurses ${ }^{3}$ have been restored and attempts are ongoing to revive the National Health Insurance Scheme which is meant to make basic healthcare affordable to all citizens. ${ }^{4}$

There has been relative stability in the value of the cedi and interest rates from the Central Bank have also reduced but this has not translated to the benefit of the ordinary citizen as the commercial banks continue to charge exorbitant interest on loans, making it difficult for local businesses to thrive. There is the attempt on the part of government to implement a policy of one factory 
for each of the 254 administrative districts in the country and provision of dams for rural areas whose main economic activity is agriculture. The appointment of the President of Ghana, Nana Addo Danquah Akuffo-Addo, together with the Prime Minister, Erna Solberg of Norway, as co-chair of the Sustainable Development Goals Advocates in April 2017 is an added inspiration to the new government in its attempt to achieve both political and economic success.

\section{Pentecostals and social action}

Early Christian thinking on mission and development was of a divisive nature. Some Evangelical Christians and particularly Pentecostals did not support the view that the church should put time and resources into development programmes or social action but rather focus on its primary task of evangelism and soul winning. It becomes obvious that 'the modern assumption that the spiritual and the material were unrelated areas of life had infected Christian mission thinking' (Myers 1999, 2). Myers argues that this idea goes back to a western worldview:

I will struggle to overcome problems presented by the persistent and insistent belief in the West that the spiritual and physical domains of life are separate and unrelated. This assumption has invaded and controlled almost every area of intellectual inquiry, including development theory and practice as well as much Christian theology. I will seek an understanding of development in which physical, social and spiritual developments are seamlessly interrelated.

$(1999,1)$

Over the past three decades, Pentecostalism has become the focus of considerable historical and sociological research with scholars writing on a wide range of themes in the development of the Pentecostal/Charismatic movement. Pentecostalism is a renewal movement within Protestant Christianity that places emphasis on a direct personal experience of God through baptism with the Holy Spirit, with evidence of speaking in tongues or glossolalia. Many scholars trace the origins of Classical Pentecostalism to the early part of the twentieth century in 1901, with Charles Parham as the leader. The initial experience was recorded at the Bethel Bible School in Topeka, Kansas in the United States of America. However, it was the ministry of Joseph Seymour, a student of Parham, and the revival that took place in 1906 at Azuza Street, which brought classical Pentecostalism to global prominence (Hollenweger 1972). A similar movement known as Neo-Pentecostals or Charismatics emerged in the 1950s where tongues speaking was not always regarded as essential evidence of baptism with the Holy Spirit. In both movements there is a strong link between baptism in the Spirit and evangelisation.

In 1970, David Barrett boldly predicted that the number of Christians in Africa would reach 350 million by the year 2000. This was from a mere 
10 million in 1910 (Barrett 1970, 39-54). In 2001, Barrett published the second edition of his seminal World Christian Encyclopedia, and estimates the actual Christian population to be 360 million, which was more than he had previously predicted. His classic reference book further illuminates the changing demography of modern Christianity and the massive shift of the faith's centre of gravity from the West to the southern continents of Asia, Africa and Latin America (Barrett et al. 2001). And for the first time in Christian history, we were told that at the beginning of 2018, there are about 631 million Christians in Africa ahead of Latin America, Asia and Europe. This makes Africa the continent with the majority of Christians in the world (Johnson et al. 2018, 4). What is significant for this study is Jenkins's observation that the stupendous growth of the church in Africa, Asia and Latin America lies principally in the Pentecostal/Charismatic strand of Christianity, which are far more traditional, morally conservative, evangelical and apocalyptic than their northern counterparts (Jenkins 2007, 7-8).

In spite of the impressive statistics about the growth of the church in Africa and particularly among the Pentecostals, there remain a number of issues that need to be explored and answers found to the question such as why the church in Africa does not have a corresponding positive effect on the social and economic lives of the people? It is estimated that Africa continues to have a high number of its citizens fleeing the continent as refugees to seek greener pastures in the West.

The office of the United Nations High Commissioner for Refugees (UNHCR) report 'Global Trends: Forced Displacement in 2016' indicates that nearly 66 million people have been displaced around the world as refugees (UNHCR 2017, 2). Nearly one-quarter of the refugees are in Africa. Conflicts in South Sudan, Sudan, Central African Republic, Somalia and Nigeria have driven nearly 15 million Africans from their homes (UNHCR 2017, 6).

African refugees move in all directions. Some venture to neighbouring African countries where economic and political lives are deemed to be better. According to the UNHCR report, the African countries with the highest number of refugees include Uganda $(940,835)$, Ethiopia $(791,681)$ Kenya $(451,099)$, Chad $(391,251)$, Cameroon $(375,415)$ and South Sudan $(262,560)$ (2016, 60-63).

Other refugees and migrants risk the treacherous routes to North Africa en route to Europe and Asia. In the process many lose their lives, while others are taken into forced labour by their captors. Many Ghanaian women who journeyed to Saudi Arabia in search of a better life ended up as sex slaves and suffered horribly. As refugees and illegal immigrants, such persons are vulnerable and barely have any access to judicial processes and human rights protection. In Ghana, the Ministry of Foreign Affairs recently issued a ban on the travel of Ghanaian women to Saudi Arabia in search of jobs (Daily Graphic 2017, 20).

\section{A new era of Pentecostal missiology and development}

The last decade has seen a new development in the missionary thinking of many Pentecostal and Charismatic Churches in Africa. About two decades ago, these 
churches were principally associated with the American Faith Gospel and prosperity teaching (Anim 2003; Gifford 1998). It has become abundantly clear that Pentecostals are not only making their mark in the social and economic space of the nations but also becoming politically influential. The current President of the Republic of Ghana, Nana Akufo-Addo, openly declared that the immediatepast Chairman of the Church of Pentecost, Apostle Professor Opoku Onyinah, is his spiritual adviser. Bishop Charles Agyin-Asare of the Perez Chapel International was known to be the spiritual adviser to the late President Atta-Mills, while Archbishop Nicholas Duncan-Williams of the Christian Action Faith Ministries was known to have a close association with the ex-President Jerry John Rawlings of the PNDC government. It is without doubt that the Pentecostal and Charismatic Churches have a very large following in Ghana.

\section{The Church of Pentecost and sustainable development}

The Church of Pentecost (CoP) was founded in 1962 by an Irish missionary, Rev. James McKeown. McKeown's history in Ghana stretches all the way back to 1937, when he first arrived in the Gold Coast at the invitation of the Faith Tabernacle Church, led by Peter Newman Anim. For a good study of the history of the CoP, see Leonard (1989) and Onyinah (2016, 12-35). By the time James McKeown retired from active service as a missionary-pastor and returned home to Northern Ireland in 1984, the CoP was well established in Ghana with additional branches in Côte d'Ivoire, Togo, Benin, Burkina Faso, Sierra Leone, Benin, Nigeria and Liberia.

The CoP currently has a worldwide membership of about 3,037,068 represented in 99 countries across the globe. The CoP, with the current membership of about 2,566,818, constitutes about 9 per cent of the total population of Ghana.

The significance of the $\mathrm{CoP}$ in the social and economic development of Ghana is best summed up in the words of the Vice President of the Republic of Ghana, Mahamudu Bawumia, who hailed the church as a model and inspiration for Ghana's quest for social and economic development. Bawumia's point was that the CoP has proved through its effective organisational structure and infrastructure that it was possible for Ghana to develop without relying on external aid. The $\mathrm{CoP}$ is on record as having used indigenous resources to impact their communities without reliance on foreign aid. In a paper presented by the General Secretary of the CoP, Apostle Nana Yaw Kumi-Larbi, at a function organised by the government, Kumi-Larbi made the point that 'with the right kind of leadership and prudent management of resources, the vision of Ghana beyond aid is not only realistic but achievable'. The CoP has established 84 basic schools, eight health institutions, two senior high schools, three vocational institutes, a university college and a theological seminary all from its own internal resources.

The modern Pentecostal Convention Centre (PCC), which has the capacity of a 5,000-seater auditorium, a 3,000-seater auditorium as well as a 500-and 
200-seater auditorium and facility for 2,500 en suite accommodation for various conferences were constructed within the record time of about four years. The Pentecost Theological Seminary and a modern police station with staff accommodation were all constructed by the church within a six-year period at a total cost of about GHS169.2 million or approximately US $\$ 37.6$ million. The PCC which is situated on a 250-acre land has played an important role in the regeneration of the Gomoa Fetteh community which has since seen significant improvement in the immediate local economy.

\section{'Pentecost model' and value for money conference}

The CoP has been noted as a leading player in the construction of progressive Pentecostalism. Following James Forbes's analysis of 'Progressive Pentecostalism', David Daniels observes that since 1979, the CoP has 'widened its scope of social ministry as it improves the lives of the marginalised in society, expanded its theology of social engagement, embraced the four traditions of philanthropy, and played a pivotal role in the strengthening of civil society as it has promoted social development and fostered civic trust within Ghana' (Daniels III 2018, 50). Daniels's assertion is underscored by the invitation of the government of Ghana for the CoP to explain the nature and approach of its social and economic projects. Presenting a paper entitled 'Value for Money in the Construction of School: A Case Study of the Church of Pentecost', the General Secretary of the church, Apostle Alexander Nana Yaw Kumi-Larbi, outlines some cost-effective means adopted by the church in constructing educational facilities.

Apostle Kumi-Larbi explains that the $\mathrm{CoP}$ follows five policy guidelines, namely: procurement-related factors, design value/engineering and technical post-contract supervision, cost management factors, audit monitoring and evaluation of projects and strong internal organisational culture. Kumi-Larbi who is also a civil engineer by profession explains that with the exception of minor maintenance works, all new works are subjected to competitive tendering with the high potential of cost savings. By procuring construction materials and paying for labour together with strict adherence to policies on procurement procedures during tendering and by ensuring promptness in the procurement process for the delivery of infrastructural projects, the church is able to reduce the overall cost of its infrastructural project by 15 to 25 per cent. The CoP also has other control measures in place such as the audit, monitoring and evaluation (AME) unit at the headquarters, which provide checks and balances for works supervised by the consultants and also provide controls for projects executed. The audit division reviews financial submission, the monitoring division provides quality control services, while the evaluation division is responsible for providing value engineering services.

The Value for Money Conference was held in Accra on 25 June 2018, and chaired by the vice president of Ghana. The conference was attended by government officials and leaders from the private business sector including Hon. 
Yaw Osafo Maafo (Senior Minister), Hon. Ken Ofori-Atta (Minister of Finance), Tony Debre (Head of Projects, Ghana Education Trust Fund), Mr Rajiv Aggarwal (World Bank) and Robert Kuzoe (MTN Ghana).

\section{Evaluation}

Kwame Bediako draws attention to a framework which can better help to evaluate understanding of the mission of the church and particularly in reference to both its spiritual and moral impacts. In his article, 'What Is the Gospel' (1970), Bediako makes it clear that the church has often misunderstood its mandate of the Great Commission. He observes, the Gospel of salvation which comes through Jesus Christ has more to do with the nations and the things which make nations, than it has often assumed. He explains that the Great Commission, therefore

is about the disciplining of the nations, the conversion of the things that make people into nations - the shared process of thinking, the shared and common attitudes, worldviews, perspectives, languages, cultural and social and economic habits of thought and behaviour and practice - all those things and the lives of the people in whom those things find expression.

(Bediako 1997, 3)

Thus, Bediako goes on to explain that we have often become so used to regarding the Gospel as concerned with individuals that we are much less alert to its

fundamental relationship to those elements and dimensions of our human existence which designate as culture - language, social values, cultural norms, religion, political organization, ethnic identity, technology, arts and craft and economic activity.

In this regard, the tendency has been to reduce the Gospel to a category we regard as purely spiritual and has no reference to our culture or way of life. The danger here, Bediako observes, is that Christianity at best becomes an overlay of already existing worldview and mentalities, 'our old habits and attitudes and fears, of some regulations and traditions and solutions which do not answer to our needs' (1997, 3). Thus, mission and evangelisation is about transformation of people and cultures in the light of God's word. While in the past most Pentecostals have frowned at social action and development issues, it is the case that this tendency is fast changing in favour of a more comprehensive and holistic approach to Christian mission. In 1980, the CoP established the Pentecost Welfare Association (PENTWAS), which subsequently became the Pentecost Social Services (PENSOS) in 2000. PENSOS was given a directorate and a mandate to provide education, health facilities, relief services and address social needs among its members and the communities in which the church operates. 
The CoP also provides funding for the Ghana AIDS Commission and is actively involved in the campaign to forestall environmental degradation and to keep the communities clean. On 22 November 2018, the CoP launched a major environmental campaign in collaboration with the Zoomline waste management company in Accra. The ceremony, which received extensive media attention was attended by Ministers of State and a cross section of the Ghanaian public and church members. The theme for the environmental care campaign was 'My Environment, My Responsibility'. In this campaign, attention was given to sanitation and environmental cleanliness, land and water pollution, air pollution and waste management. As a church initiative, the Church of Pentecost has called on all its members and particularly the ministers throughout the country and in all other nations where the church has branches to spearhead this vision. The church also uses its private television network, the Pent TV, to discuss relevant issues on environmental care and educate the wider public on the need for environmental preservation as a divine responsibility to be stewards of God's creation. However, a lot more needs to be done as what can be said of the Church of Pentecost cannot be said of many other Pentecostal and Charismatic Churches in Ghana, some of whose activities have recently been called into question. There are several accusations of some African Initiated Churches (AICs) such as the prophetic ministries or churches whose leaders are known to take undue advantage of their congregation and extort monies from them without any accountability. This situation has necessitated a debate as to whether the churches in Ghana should be made to pay taxes to the state in view of the perception that the churches have now become business ventures and avenues for economic exploitation and abuse of power.

\section{Conclusion}

During his official visit to Ghana in July 2009, President Obama of the United States of America made the point in his address to Parliament that 'Africa doesn't need strong men, it needs strong institutions' that work. This was part of his speech made to the Parliament. Sustainable development should always take into consideration the socioeconomic structure of the community. In the same vein, development models in Africa should be bottom-up rather than topbottom. It should seek to empower the masses through education, healthcare and small-scale enterprises and the religious community has an important part to play.

We have looked at two distinct but related issues in African experience. The conflicts in Africa also have socioeconomic consequences which impact negatively on national and individual development. Our analysis has shown that the situation is quite complex. The legacy of colonialism continues to be felt even in modern African states. The traditional African worldview and mentality hold sway when it comes to work ethics.

The issue of kinship ties, nepotism, ritual taboos and corruption are critical to Africa's development and need to be addressed. Here, the Christian mission 
can make a contribution by helping people to see beyond specific ties to the family and personal interest. The late Professor Kofi Abrefa Busia, a sociologist and lay preacher of the Methodist Church Ghana, and former Prime Minister of the Republic of Ghana, observes thus:

For the conversion to the Christian faith to be more than superficial, the Christian church must come to grips with traditional beliefs and practices, and with the worldview that these beliefs and practices imply. It would be unreal not to recognize the fact that many church members are influenced in their conduct by traditional beliefs and practices, and by the traditional interpretation of the universe. The new convert is poised between two worlds: the old traditions and customs he is striving to leave behind, the new beliefs and practices to which he is still a stranger. The Church would help him better, if she understood the former, while she spoke with authority about the latter.

(Busia 1955, 4)

It is gratifying to note that in the last two decades, the CoP has sought to engage the worldview and culture of the people and confront the ills of society while addressing the spiritual needs of its members. As Pentecostals debate globally whether social ministry may complement evangelism or undermine it, the $\mathrm{CoP}$ has wholeheartedly embraced an understanding of holistic ministry that combines evangelism and social action or intervention without apology (Daniels III 2018, 51). Peace and development may not necessarily be the absence of war but the presence of Christ who fulfils the dreams of the poor and the destitute (Luke 4:16-18) and calls into account the rich and the powerful. This message should not be told only in the church but to the wider society. We maintain that this is the path some Pentecostal Churches in Africa have chosen and the CoP remains one of the best models worthy of investigation.

\section{Notes}

1 I prefer the term, 'primal' to primitive as the latter carries a derogative impression.

2 Accra Metropolitan Assembly, press release, Thursday 10 May 2018; Ref. A.025/6/25, 'Ban on Drumming and Noise Making'. Signed by Gilbert Nii Ankrah, Head of Public Relations for the Metropolitan Chief Executive. Further information available at www.ghanaweb.com. Dailyguideafrica.com

3 'Nurses Training Allowances Restored', www.ghana.gov.gh/imdex.php/news/4064restoration-of-nursing-training-allwances-have-come-true-president. Accessed 7 April 2019. About 58,000 health training nurses and midwives whose monthly allowance of about $\$ 80$ was stopped by the previous administration were restored in 2018 by the Akuffo-Addo government.

4 See 'GHC1.2bn NHIS debt inherited from NDC fully paid off', https://mobile.ghanaweb. com/GhanaHope Page/NewsArchives/GHC1-2bn-NHIS-debt-inherited-from-NDCfully-paid-off-Bawumia-699436. GhanaWeb, Health News of Fri, 9 November 2018, The amount is an equivalent of about $\$ 300$ million. Also reported on Myjoyonlne.com, 21 April 2018.

5 Barack Obama, reported on www.sundaytimes.lk/090712/International. Accessed 7 April 2019. 


\section{References}

Anim, Emmanuel. 2003. 'Who Wants to be a Millionaire? An Analysis of Prosperity Teaching in the Charismatic Ministries (Churches) of Ghana and Its Wider Impact.' Ph.D. thesis, All Nations Christian College, The Open University, UK.

Asante, Felix A., and Kenneth Owusu. 2013. 'Overview of Ghana's Development: Policies and Options.' In Policies and Options for Ghana's Economic Development, edited by Kodwo Ewusi. Accra: Institute of Statistical, Social and Economic Research, University of Ghana.

Barrett, David B. 1970. 'AD 2000: 350 Million Christians in Africa.' International Review of Mission 59: 39-54.

Barrett, David B., George Thomas Kurian, and Todd M. Johnson, eds. 2001. World Christian Encyclopedia. 2nd edition. New York: Oxford University Press.

Bediako, Kwame. 1997. 'What is the Gospel?', Transformation 14, no. 1: 1-4.

BMZ. 2016. Religious Communities as Partners for Development Cooperation. Berlin: Bundesministerium für wirtschaftliche Zusammenarbeit und Entwicklung.

Busia, K. A. 1955. 'The African World View.' In Christianity and African Culture: The Proceedings of a Conference Held at Accra, Gold Coast, May 2nd-6th, 1955. Accra: Christian Council of the Gold Coast.

Daniels III, David D. 2018. 'Progressive Pentecostalism, Pentecostal Philanthropy: The Church of Pentecost.' In African Pentecostal Missions Maturing: Essays in Honor of Apostle Opoku Onyinah, edited by Elorm Donkor, and Clifton R. Clarke. Eugene, OR: Pickwick Publications.

Davidson, Basil. 2005. The Black Man's Burden: Africa and the Curse of the Nation-State. Ibadan: Spectrum Books Ltd.

Foster, George McClelland. 1973. Traditional Societies and Technological Change. New York: Harper \& Row.

Gifford, Paul. 1998. African Christianity: Its Public Role. London: Hurst \& Co.

Gifford, Paul. 2004. Ghana's New Christianity: Pentecostalism in a Globalizing African Economy. Bloomington \& Indianapolis: Indiana University Press.

Hollenweger, Walter J. 1972. The Pentecostals. London: SCM Press.

Jenkins, Philip. 2007. The Next Christendom: The Coming of Global Christianity. Oxford: Oxford University Press.

Johnson, Todd M., Gina A. Zurlo, Albert W. Hickman, and Peter F. Crossing. 2018. 'Christianity 2018: More African Christians and Counting Martyrs.' International Bulletin of Missionary Research 42, no. 1: 20-28.

Leonard, Christine. 1989. A Giant in Ghana. Chichester: New Wine Ministry.

Myers, Bryant L. 1999. Walking with the Poor: Principles and Practices of Transformational Development. Maryknoll, NY: Orbis Books.

Myers, Bryant L., ed. 2011. Working with the Poor: New Insights and Learnings from Development Practices. Monrovia, CA: World Vision.

Onyinah, Opoku. 2016. 'Pentecostal Transformation in Africa: The Rise and Growth of the Church of Pentecost.' Pentecost Journal of Theology and Mission 1, no. 1: 12-35.

Rostow, Walt Whitman. 1990. The Stages of Economic Growth: A Non-Communist Manifesto. 3rd edition. Cambridge: Cambridge University Press.

Weber, Max. 1976. Protestant Ethic and the Spirit of Capitalism. Sydney \& Boston: George Allen \& Unwin. 


\section{Internet and newspaper sources}

Daily Graphic. 'Recruitment of domestic servants to work in Gulf States suspended.' Thursday 1 June, 2017.

UNHCR. 2017. 'Global Trends: Forced Displacement in 2016.' www.unhcr.org/5943e8a34. www.globalissues.org/Geopolitics/Africa

www.globalissues.org/issue/83/conflicts-in-africa

www.cfr.org/africa/africas-conflict-zones/p14543

www.moibrahimfoundation.org/en 


\title{
14 Pentecostalism and sustainable development
}

\author{
The case of Perez Chapel International
}

\author{
Sylvia Owusu-Ansah and Philip Adjei-Acquah
}

\section{Pentecostalism and sustainable development}

Ideas about sustainable development emerged in the 1960s when ecologists raised concerns about preserving the environment and ecosystems, overcoming the impact of economic growth on the environment. Sustainable development has been defined by many people and organisations. The most widely accepted definition was published in the Brundtland Report, released by the World Commission on Environment and Development (United Nations General Assembly 1987), which states that sustainable development is 'development that meets the needs of the present without compromising the ability of future generations to meet their own needs' (United Nations General Assembly 1987). Diesendorf $(2000,3)$ opines that 'the context in which the definition is embedded indicates that "needs" include a sound environment, a just society and a healthy economy'. The definition stipulates that sustainable development encompasses the interconnection of three major elements: economic growth, social cohesion/ inclusion and environmental protection. Sustainable development is a goal by all humans for all humans. It demands determination in building a comprehensive and resilient viable future for all (Environmental Bureau 2017). Bob Giddings et al. $(2002,187)$ argue that even though the three concepts that define sustainable development are interconnected, they can be viewed 'as separate although connected entities'. Since 'economy is dependent on society and the environment while human existence and society are dependent on, and within the environment, efforts toward achieving sustainable development must look at issues holistically' (187). Environmental degradation and mismanagement/mishandling of natural resources can cause economic hardship leading to famine. An example can be cited of the 1983 hunger in Ghana because of bushfires and deforestation and mismanagement of Ghana's economy (AsamoahGyadu 2013, 63).

Sustainable development and holistic development therefore go together. By definition, holistic development is a development that takes into consideration the totality of human needs. That includes the physical, spiritual, moral, psychological, mental and the emotional needs of people. Holistic development can provide the rationale for achieving sustainable development. Building a 
viable economy, an inclusive society and an enabling environment all depend on the people who live in the society. The path of sustainable development must lead to the building of lives of the human beings in the society who would then build the economy and enhance the environment. Human resource development within society is therefore crucial to the development of every community. Education then becomes the bedrock for building the capacity of the individual which reflects on the economy and the society as well as the environment.

This study takes cognisance of various debates about the meaning of sustainable development. Some argue that the Brundtland definition is not adequate as it puts more emphasis on the human species (Giddings et al. 2002, 188) than on the environment. Sustainable development is a balanced interconnection of the economy, the environment and the society. In the words of Emas, " $[\mathrm{t}]$ he overall goal of sustainable development (SD) is the long term stability of the economy and environment; this is only achievable through the integration and acknowledgement of economic, environmental, and social concerns throughout the decision making process' $(2015,2)$.

The study sought not to contest meanings but to highlight the contribution of Pentecostalism to the development of human resource and the society. The Brundtland definition is therefore still essential and a good foundation for a relevant conceptual framework to build upon. Sustainability defines the global development agenda 2030 with the Sustainable Development Goals (SDGs) set up for international collaboration (United Nations 2018). The goals have 17 universal targets which apply to all countries of the world. These targets are to be achieved by 2030. All hands are expected to be on deck if these goals are to be achieved. Corporate bodies, institutions, businesses and governments and non-governmental organisations (NGOs) are all responsible for the implementation of these goals. Goal number four of the target list is quality education, which has many implications for sustainable development (United Nations 2017). The church is therefore not left out as it has a significant responsibility towards humanity and the universe. Koegelenberg (2016) underscores the role of churches and NGOs in development in South Africa. This study examines the role of the churches in Ghana using Perez Chapel International as a case study.

Paul Gifford, a visiting lecturer to Central University College (now Central University) in the year 2000, led a discussion centred on Pentecostalism and development. The insignificant contribution Ghanaian Pentecostal/Charismatic Churches had made towards social and environmental development was noted with regret. Comparing Pentecostals with the Missionary Churches in Ghana, one could notice at a glance the difference in the impact made by each regarding development. While the Missionary Churches like Catholic, Presbyterian, Methodist, Anglican and Evangelical Presbyterians in Ghana could count so many educational schools, clinics and other projects, few of these projects could be attributable to the Pentecostal/Charismatic Churches (OwusuAnsah 2016, 597). However, in the span of 18 years after that discussion, a lot 


\section{Sylvia Owusu-Ansah and Philip Adjei-Acquah}

has happened. The Pentecostal/Charismatic Churches have taken the issue of social responsibility seriously and become partners in Ghana's socioeconomic development.

\section{Emergence of Pentecostalism in Ghana}

Pentecostalism has shifted the centre of Christianity from the western world to the southern hemisphere (Barrett and Johnson 2000, 24-25). Its emergence has changed the dynamics so much that it has become a subject of research by academics and scholars. West Africa in general and Ghana in particular is no exception (Anderson 2004; Larbi 2000). In Ghana, Peter Newman Anim is credited as being the father of Ghanaian Pentecostalism. This is because there are four major older classical Pentecostal Churches; out of these, three of them - namely Christ Apostolic Church, Apostolic Church of Ghana and the Church of Pentecost - all have their roots in the work of Apostle Peter Newman Anim. Over time, there emerged another brand of Pentecostal Churches from the late 1970s and early 1980s. These churches are known as Charismatic or Neo-Pentecostal Churches and ministries. The Neo-Pentecostal Churches developed from the para-church (fellowships) movements in Ghana in the mid1970s and 1980s. The charismatic ministries share the fundamental doctrines that the classical Pentecostal Churches believe in. The added emphasis is on healing, prosperity, faith and practical experience. Asamoah-Gyadu $(2005,97)$ notes that the term 'Charismatic Churches' has both historical and theological implications. He declares:

Historically, it refers to independent churches emerging from neoPentecostal movements since the 1970s. Theologically, the expression defines the ecclesiology of these new independent churches in which every believer is considered a potential recipient of a charisma(s) or ministry gift(s) of the Holy Spirit.

(Asamoah-Gyadu 2005, 97)

Charismatic Churches have become very vibrant and have occupied the public space due to their use of the media and modern technology (de Witte 2003). Again, the newer Pentecostal/Charismatic Churches have become partners in the development of the various nations in which they are found (Asamoah-Gyadu 2005). They have provided educational facilities, healthcare, infrastructure, potable water and social amenities for deprived communities and the vulnerable in the country (Asamoah-Kumi 2013). The purpose of these churches being partners in development is to ensure that both the members and those outside the church enjoy holistic salvation. This includes spirit, soul and body. To ensure that there is holistic salvation for total development, education is a key factor. Owusu-Ansah highlights some of the achievements of Ghanaian Pentecostal Charismatic Churches in socioeconomic development: 
On the wider socio-economic front, the CMs (Charismatic Ministries) have developed social programs including the awarding of educational scholarships to 'brilliant but needy' members. ${ }^{1}$ Pastor Otabil's ICGC runs a borehole water project in selected rural areas and as part of its 'Christ to the Rural Word' evangelistic campaigns, the Charismatic Evangelistic Ministry headed by Pastor Steve Mensah distributes items of clothing and other logistics in Ghana's rural communities.

$(2018,182)$

One of the Pentecostal Churches that has become very conscious of its responsibility and partnering the state in development is Perez Chapel International. This church is led by Bishop Charles Agyinasare (formerly Agyin-Asare).

\section{Brief history of Perez Chapel International}

Some of the sources for this part of the research were gathered through personal conversation with the presiding bishop of the church, the assistant presiding bishop, the administrative bishop, the chief accountant and other relevant persons in the organisation. ${ }^{2}$ Perez Chapel International, a Charismatic or NeoPentecostal Church, began in Tamale, the Northern Region of Ghana in 1987 by Bishop Charles Agyinasare. In 1994, the headquarters was moved from Tamale to Accra, the capital city of Ghana. Over the years, it has expanded to many communities in Ghana and beyond. The Perez Dome (the meeting place at the headquarters in Accra) has an estimated full seating capacity of 16,000. In June 2013, the name of the church was changed from the Word Miracle Church International to Perez Chapel International. Perez Chapel International operates both as a classical Pentecostal and a Charismatic Church. Its founder, Bishop Charles Agyinasare, was groomed in the Church of Pentecost after his conversion in Tamale. He received the call into ministry while in the Church of Pentecost. Even though from a classical Pentecostal background, he believes in the ordination of women, which is a Charismatic Church practice (Agyinasare, personal conversation 2018).

The lifestyle of Charles Agyinasare and other Perez Chapel pastors is worthy of emulation. This is because he has set a standard of integrity and accountability that has trickled down to the pastors in the church. As a policy, all the financial transactions of the church are handled by qualified accounting staff. Moreover, all the pastors and bishops are on salary, and spend only as authorised by a church board (Tackie, personal conversation 2018). ${ }^{3}$ Accountability to the church is an integral part of the processes. It ensures transparency in all aspects of financial transactions, thereby preventing pastoral staff from directly accessing church funds for personal gain (Tackie, personal conversation 2018). In all branches of Perez Chapel, there is a statutory handbook that ensures all follow the policy. In the church, there are both internal and external auditors that audit the accounts periodically (Tackie, personal conversation 2018). This ensures that the standards of accountability are strictly adhered to. Again, the 
presiding bishop has set a good example as a man of transparency and integrity. $\mathrm{He}$ is also one of the top 10 givers of the church in terms of financial support (Acquah, personal conversation 2018). ${ }^{4}$

Perez Chapel has a television station called Precious TV which features Bishop Agyinasare. Francis Agyin-Asare (personal conversation 2018) believes the station has an audience of millions of people all over the world. ${ }^{5}$ The emphasis of Perez Chapel International is to bring total transformation to humankind based on the word of God (Acquah, personal conversation 2018). However, the church does not offer only spiritual solutions to the problems of humanity, but also believes in the development of the whole person. It is based on this premise that Perez Chapel undertakes many developmental projects. One key project that is aimed at bringing total and sustainable development to the people especially the youth is education. This is done through two programmes named 'Formal Education' and 'Youth Explosion' (Acquah, personal conversation 2018). Scholars like Peterson have a strong view about the indifference and uncaring attitudes of Pentecostals. He emphasises, "[t]hey use their divine empowering and faith building messages for self-serving purposes and neglect the social responsibilities that should accompany this phenomenon' (Peterson 1996, 299). In the case of Agyinasare, this is not true since he stopped taking a salary from the church when he reached the age of 50 and channelled it into taking care of the less privileged in society with beneficiaries in and outside the church (Agyinasare, personal conversation 2018). Additionally, the bishop has instituted a scholarship scheme for the needy but brilliant students known as the Agyinasare Foundation. Perez Chapel as an organisation also has a scholarship known as the Kenneth Narh Scholarship scheme. These scholarship schemes fit well into Perez Chapel's theology of development which aims at the total development of church and society, by meeting the physical, psychological and social needs of beneficiaries. This is because education is pivotal to the development of every individual or nation (Acquah, personal conversation 2018). The above shows that some Charismatic Churches have been very active in contributing to the socioeconomic development of the nation (Kalu 2008). Unemployed youth who otherwise would have been engaged in some form of vices in society are able to find viable ways of earning income. This agrees with the assertion of Asamoah-Gyadu (2005, 152) that 'the transformed lifestyle of believers translates into economic upliftment when resources that are spent (wasted) on unproductive activities are channelled into other economic gainful ventures'. Thus, Agyinasare's book How Anybody Can Become Somebody aims at motivating his readers to work hard and be determined to succeed through hard work and education. The book is part of Agyinasare's educational agenda in helping to transform the lives of the youths to become productive citizens. This agrees with the call by the World Bank and other agencies for collaboration between the international partners and faithbased organisations, so as to ensure sustainable development (Box 2009). The role of education in attaining sustainable development cannot be overemphasised. Sustainable development cannot take place without human development that comes as the result of education. It is an important tool for achieving 
global development. Education at whatever level is a key contributor to human development. Human development on the other hand becomes complete when it affects the 'whole being'. As defined by UNDP, Human Development Report:

Human development is about much more than rise or fall of national incomes. It is about creating an environment in which people can develop their full potential and lead productive, creative lives in accord with their needs and interests. People are the real wealth of nations. Development is thus about expanding the choices people have to lead lives that they value. And it is thus about more than economic growth, which is only a means if a very important one - of enlarging people's choices.

$(2001,9)$

For example, an educated farmer will better understand the challenge of global warming and its effect on the quality of yield from his/her farm. This will help in appreciating the need to ensure that the environment is protected from harmful activities. No wonder emphasis was placed on education at the UN World Summit in Johannesburg (United Nations 2002). It was accepted that any direction of current and future education systems will be key to sustainable development. In the words of Nevin (2008, 50), '[e]ducation for sustainable development (ESD) promotes the development of the knowledge, skills, understanding, values and actions required to create a sustainable world, which ensures environmental protection and conservation, promotes social equity and encourages economic sustainability'. Even though the dominant theme in ESD is the environment, it addresses issues like poverty alleviation, citizenship, democracy and governance, corporate social responsibility, gender equality (Owusu-Ansah 2016). A Department of Economic and Social Affairs document by Le Blanc (2015) identified a link between education and sustainable development. It is therefore not surprising that to ensure holistic development, Perez Chapel International has made education a major priority in its quest to fulfil the Mission of God (missio Dei).

\section{Educational and development projects of Perez Chapel International}

The theology of development in Perez Chapel focuses on the total well-being of the individual (Acquah, personal conversation 2018). It has the biblical basis in 3 John 2 'Beloved, I pray that you may prosper in all things and be in health, just as your soul prospers' (NKJV, 2013). The whole being must prosper and enjoy good health. In the words of Agyinasare (personal conversation 2018), 'this theology ensures that there is a constant cycle of development of both individual and society'. The leadership under Agyinasare has established some basic schools (junior high school level) known as Perez Academy. As a church, 'we aspire to have every branch that is ten years and above to have at least a basic school unit attached to the church. This will go a long way to meeting the educational needs in the communities where the 


\section{Sylvia Owusu-Ansah and Philip Adjei-Acquah}

churches are established, especially the deprived communities' (Acquah, personal conversation 2018). Among them is the Perez Academy in Yeji, in Northern Region of Ghana, which is registered with the Ghana Education Service. The understanding of Perez Chapel and Agyinasare is that, through formal education, sustainable development can be achieved. This is evident by the provision of a six-classroom block unit to meet the infrastructural needs of the school in 2012 sponsored by the presiding bishop (Tackie, personal conversation 2018).

Currently, the school has offered employment for 17 teaching and nonteaching staff. The school has a population of 507 pupils (Yeji Pastor, personal conversation 2018). Perez Chapel International has another basic school which was purchased in 2010 by the La Branch of the church. Currently a 21-classroom block is ongoing to help admit the growing number of students (head teacher, personal conversation 2018). The passion to contribute to the sustainable development through quality graduate education received a great boost when the church purchased the Pan-African Christian University College formerly owned by the Church of God, now Perez University College. This gives credence to Burgess' $(2015,40)$ observation on current developmental and response to societal needs including education by Pentecostal/Charismatic Churches. A personal conversation with the former rector of Perez University College indicates that currently the institution has three programmes: the Department of Business, School of Theology and Communication Studies (Sekyere, personal conversation 2018). He added that plans were far advanced to develop the infrastructure for the college to meet international standards so that it can be a channel for meeting the developmental needs of Ghanaians in particular and West Africa at large. Additional courses to be taught at the college include engineering, agricultural business with emphasis on mechanised farming, applied sciences, mathematics and statistics (Sekyere, personal conversation 2018). Acquah (2018) notes in a personal conversation that 'the college aims at turning out graduates that will contribute to sustainable development to ensure that no one is left behind as the world strives to meet the Sustainable Development Goals'.

\section{Holistic development: agents of change}

As stated earlier, holistic development is a development that takes into account the total growth needs of the individual or community (physical, mental, psychological, social and moral). Speckman $(2016,1087)$ defines it as 'a process of releasing an individual's potential so as to enable him/her to contribute to the welfare of the politeia/city'. Thus, the individual becomes an agent of positive change after he/she has been transformed. The change may come by various means and at different levels in a person's life, yet the youths are more likely to cause the changes the world is expecting if they are positively affected. The concept of holistic youth development includes activities that strengthen the whole young person (Fletcher 2014). This idea of holistic development as 
expressed agrees with Freeman's (2013) holistic development term 'transformational development'. It is the development that seeks to transform the material, social and spiritual life of an individual. Thus, one of Agyinasare's approaches is to help empower the youths who are the future leaders through a programme dubbed 'Youth Explosion'. Perez Chapel seeks to provide the youths with the necessary tools - spiritual, social and physical - for sustainable development that is holistic. This is the aim of the Youth Explosion programme. Frederick Kakwata (2017) describes progressive Pentecostals as 'Christians who, inspired by the Holy Spirit and the life of Jesus, seek to address holistically the spiritual, physical, and social needs of people in their community'.

\section{The Youth Explosion programme}

Youth Explosion is a non-denominational youth empowerment platform organised annually by Charles Agyinasare. The nature of the programme is such that everybody can participate irrespective of their religious background or persuasion. It was started on 24 July 2006 as Perez Chapel's contribution to youth empowerment in Ghana (Acquah, personal conversation 2018). Themes for the programme are carefully selected to meet the needs of the youths. Issues that are addressed span across moral, educational, physical, psychological and political concerns. The first conference was held at the International Conference Centre in Accra, Ghana, under the theme 'Breaking the power of bad addiction'. Some of the subsequent themes of the programme were as follows: 2007, 'Breaking the power of indiscipline'; 2008, 'Breaking the power of apathy'; 2009, 'Building an unshakable character for success'. Examining carefully the three examples mentioned, it is evident that the themes are reflective of the challenges confronting youths.

Addiction has become a global issue that is affecting humanity. The rate at which the youths, who are easily carried away by peer pressure, succumb to drug or substance abuse that leads to addiction has become a serious challenge (Gowing et al. 2015, 14). The reason for the 2016 theme of Youth Explosion was to assist the youths in overcoming the menace of substance abuse (Agyinasare, personal conversation 2018). The programme was aimed at helping them to contribute effectively to sustainable and holistic development. A participant attested to the positive influence the programme has had on his life: 'The programme has helped me to understand the danger of drug abuse and addiction, I am more than determined not to allow myself to be entangled with any sort of addiction whatsoever' (participant 6, Youth Explosion 2006). The underlying motif behind the organisation of Youth Explosion is addressing the vices, concerns and challenges of the youth in Ghanaian society in order to prepare them for future leadership (Acquah, personal conversation 2018).

Through the programme, the young people are informed, highly motivated and encouraged as the speakers inculcate in them the impetus for excellence to be able to contribute to socioeconomic development. A participant confessed after the 2009 edition, 'I have never seen myself as anyone who can become 
successful but after this conference, I am so sure that no matter what comes my way, I will succeed and help my nation Ghana to develop' (participant 7, Youth Explosion 2009). Another participant also testifies how he has been set free from marijuana (substance abuse) due to his participation in Youth Explosion (participant 1, Youth Explosion 2010). Youth Explosion grew tremendously after the first two editions. The initial venue, the International Conference Centre, could no longer contain the number of participants. The conference venue was therefore moved to the Trade Fair Centre, La, Accra in 2008. In 2009, Youth Explosion was also held in Kumasi, the second biggest city in Ghana, the capital of the Ashanti Region. Due to its success and influence, the Youth Explosion programme is currently held in Accra, Takoradi, Kumasi and Tamale (these are the four biggest cities in Ghana). The long-term vision of Agyinasare is to hold the programme in each of the 10 regions of Ghana. $\mathrm{He}$ also wants to institutionalise the programme into a club to function in junior high schools, senior high schools and tertiary institutions throughout the country (Agyinasare, personal conversation 2018).

Motivation and encouragement are keys in moving people from one level of understanding to the other. The youths are usually influenced when they are motivated by people they consider as role models (Bush et al. 2001). Pleiss and Feldhusen (1995) suggest that a role model is a person who is perceived by others as worthy of imitation and who may or may not have personal contact with the people who perceive him/her as a role model. Leadership experts like John Maxwell (1993), Sam Chand and Murphey Cecil (2003), Myles Munroe (2005) and Brian Tracy (2014) all agree that influence is one of the major elements in leadership and this of course must be positive influence. The youths are influenced when they meet their role models in seminars and programmes. The idea of Agyinasare is to give the youths an opportunity to interact with people who have been successful in their various fields of endeavour (personal conversation 2018). The Youth Explosion programme therefore draws resource persons from different sectors of life to talk about issues of national interest. These are people of experience and expertise who will have a positive influence on the youths. The subjects of interest include career counselling and moral, relationship, educational, political and career issues. Organisations that have played important roles in youth development and nurturing have been involved in Youth Explosion since its inception. Such organisations include: Ghana AIDS Commission, Child's Right International, the National Youth Council and the Scripture Unions. Moreover, education is essential in the development of youths. As stated earlier, sustainable development cannot take place without education. Based on this assertion, some educational institutions have also been represented to give the youths an opportunity to interact with academics and fellow students. As part of the activities, an educational fair is organised for institutions that are both academic and vocational to exhibit their products, services and activities to the youths. The youths and participants are guided on the enrolment processes and procedures. Some of the educational institutions which have participated in Youth Explosion between 2006 and 2016 include 
Central University, Regent University College, Data Link University College, Tropical Haven, Sikkim Municipal University College, Wisconsin University College, 2nd Image and Beauty School and Cake Techniks (Acquah, personal conversation 2018).

The Presiding Bishop of Perez Chapel International is one of the key Pentecostal/Charismatic leaders in Ghana. Consequently, some of his colleagues have been resource persons for the Youth Explosion programme. This gives the programme the 'non-denominational and multidimensional' status. Churches that have been participating in the programmes are Perez Chapel International, Victory Bible Church, Global Revival Ministries, Methodist Church of Ghana, Anglican Church of Ghana, Presbyterian Church of Ghana and many others. The programmes are structured to be exciting and educational. The activities include lectures and entertainment with issues on health, entrepreneurship and politics and are designed to encourage socialisation. Some notable resource persons from different walks of life who were invited to address the participants at the Youth Explosion programme in 2008 include Rev. Dr Mensa Otabil; Mr Yussif Ibrahim, Drug Abuse Counsellor; Prof. Mike Aquaye; Bishop Tackie Yarboi; Mr Kofi Addison, CEO, Mature Leadership Consultant; Bishop E. A. Sackey; His Excellency the late former Vice President of Ghana, Alihu Mahama; His Excellency John Dramani Mahama; the former President of Ghana, Rev. Dr Robert Ampiah Kofi; Rev. Dr Ebenezer Markwei; Rev. Kyre Searcy (USA); Rev. Robert Andoh; Dr Paa Kwesi Ndoum and Ms Peggy Addo, Human Resource Manager, Graphic Communications Group. These are people of immense experience and expertise in their various fields of endeavour. Their experiences are shared in lectures and symposia with the opportunity for questions and answers. Available information shows that the programme has grown from year to year in terms of attendance and the content (Acquah, personal conversation 2018). The resource persons have influenced the youths so much that, as one participant puts it, 'my life since the attendance of Youth Explosion has never been the same' (participant 5, Youth Explosion 2015). In order to ascertain the positive influence of the Youth Explosion, interviews were conducted with some of the participants.

\section{Interviews on the influence of Youth Explosion}

Youth Explosion attracts young people from all religious persuasions (Christians, non-Christians and Muslims) alike. The youth in Ghana who are aware of the programme look forward to it, as one participant attests: 'I am always looking for Youth Explosion, I wish it will be held here in every month, God bless Bishop Agyinasare for the great foresight' (participant 4, Youth Explosion 2010). Participants of the programme have benefited in diverse ways. After the programme in Kumasi in 2014, one of the participants testified how she had learned to structure her daily activities, and the orderliness that has come to her life due to lessons learned in one of the sessions. She opined, 'these days, I write down my activities in a scheduled format, and try as much as possible to follow it. At the 


\section{Sylvia Owusu-Ansah and Philip Adjei-Acquah}

end of every day, I go through my checklist to see whether I have been able to fulfil my plans for the day' (participant 3, Youth Explosion 2014). The greatest joy of another participant was the fact that he has been able to speak to a public figure in Ghana. He stressed: 'In Ghana if you don't know anybody you cannot get access to talk to the big men, but Youth Explosion has made it possible for me to talk to a former Vice President; I am excited' (participant 8, Youth Explosion 2010). Life principles and effective skills development are some of the things the youth learn during the programme. Another participant in the 2013 edition confessed, 'they have taught on some life principles which will help everyone especially the youth, so I would encourage everyone to make it to this programme, and truly, whoever makes it to this programme would be a blessing' (participant 2, Youth Explosion 2013). Self-identity and confidence are keys in reaching one's purpose in life. At Youth Explosion, experience counsellors have the opportunity to interact with and counsel young people who have low selfesteem due to their family backgrounds and the environments in which they are nurtured. Baumeister et al. (2003) emphasise that self-image (self-concept) comprises a value for one's self and respect; made up of which is the feeling of one's own value and the belief to have the right to happiness and success. A participant affirms that through the programme his self-confidence has been built up, ready to face the challenges in this life for success. A lady who has been part of Youth Explosion since its inception in Kumasi testified that:

I think it's been so much a blessing because it has impacted my life and changed my way of thinking. I think that I can do something no matter my age. And especially today, I have been motivated primarily by Nana Bediako's speech. If at the age of 21 years, he was a millionaire in pounds, I don't know what I can't do with the help of God, so I'm sure I'm going on for the best and am on course.

(participant 9, Youth Explosion 2010)

The resource persons have served as role models for the youths. A participant in Tamale explained how she has been impacted by the programme. She stressed:

Youth Explosion has been very impactful. It has given me the opportunity to learn a lot of things about life, and how the big men like the pastors that we see around, the bishops, how they were able to go through the odds and to come out and to make it big. So, they've impacted us, and inspired us, to be able to go on and to move on despite all the hindrances and the challenges that we go through. If we hold on and we move on as they did, we'll also get to where they got to. So, it has been very impactful.

(participant 10, Youth Explosion 2010)

Activities like music, choreography, praise and worship, entertainment, talent hunts and reality shows help to unearth the talents of participants. ${ }^{6}$ The youths play important roles in the activities of the programme, serving as 
encouragement to others who are school dropouts. A participant testified how through Youth Explosion she has gathered the courage to go back to school after dropping out due to pregnancy and childbirth (participant 11, Youth Explosion 2016). With the purchase of the university college in 2015, Perez Chapel International could not organise Youth Explosion in 2017 and 2018. The reasons given by the presiding bishop and initiator of the programme is that much finance from the church is being channelled into infrastructure development at the college, which puts much constraint on the finances of the church. Attention is now focused on human resource development and youth empowerment at the university college.

\section{Conclusion}

Sustainable development is critical to every country. Over the years, organisations and institutions have contributed to the success of programmes and policies of development in their various countries. SDGs hold the future for the entire world to eradicate extreme poverty. It is expected that all hands will be on deck in contributing to efforts that focus on sustainable development. Religious organisations (church and para-church organisations) need to work in diverse ways towards social development. The history of Christianity in Ghana records many development initiatives by the Mission Churches such as the building of schools, hospitals and clinics. Records suggests that much work has been done by the Christian community in Ghana in terms of human resource development, capacity building and assisting the less privileged to secure a means of income.

In recent years, Ghanaian Pentecostal and Charismatic Churches have been involved in social development, which was not the case some years back. Mention can be made of churches like International Central Gospel Church, which has one of the top private universities in Ghana, Lighthouse Chapel International, which has built a hospital, Action Faith Chapel International, which has a university college, and Perez Chapel International, which has acquired a university college and some elementary schools. This study has looked at the contribution of Perez Chapel International to sustainable development. Apart from the Perez University College, which serves as a training and educational institution in Ghana, and other primary schools, the founder of Perez Chapel International, Charles Agyinasare, embarks on an annual capacity building programme which empowers the Ghanaian youth, Christians and non-Christians alike, to unleash their potential for productive activities. The Youth Explosion programme has had a tremendous influence on Ghanaian youth. Development is a critical issue which needs the attention and contribution of all. The Pentecostal Churches are therefore not exempted from this important task. 


\section{Sylvia Owusu-Ansah and Philip Adjei-Acquah}

\section{Notes}

1 Our own explanation in brackets.

2 Detailed information about the interviews including dates can be found at the end of the chapter.

3 Robert Tackie, a qualified and renowned chartered accountant who works with the State Judiciary Service, is chief accountant of Perez Chapel International.

4 Rev. Raymond Acquah is the Bishop Elect in charge of the church's administration, known as the Administrative Bishop.

5 Francis Agyin-Asare is the Director of Precious TV.

6 Even though the programme is Christian in nature, youth from other religious persuasions participate. Muslims who attend the programme sing along with the other participants and dance to the Christian music as well.

\section{References}

Anderson, A. 2004. Introduction to Pentecostalism. Cambridge: University Press.

Asamoah-Gyadu, J. K. 2005. African Charismatics: Current Development Within Independent Indigenous Pentecostalism in Ghana. Leiden: African Christian Press.

Asamoah-Gyadu, J. K. 2013. Contemporary Pentecostal Christianity - Interpretations from an African Context. Oxford: Regnum Books Int.

Asamoah-Kumi, Moses. 2013. 'The Execution of Social Responsibility as an Image Building Strategy: The Case of International Central Gospel Church.' European Journal of Business and Social Sciences 2, no. 7: 180-191.

Barrett, David B., and Todd M. Johnson. 2000. 'Annual Statistical Table on Global Missions.' International Bulleting of Mission Research 24, no. 1: 24-25.

Baumeister, Roy F., Jennifer D. Campbell, Joachim I. Krueger, and Kathleen D. Vohs. 2003. 'Does High Self-Esteem Cause Better Performance, Interpersonal Success, Happiness, or Healthier Lifestyles?' Psychological Science in the Public Interest 4, no. 1 (May 2003): 1-44.

Box, Louk. 2009. 'Religion and Development: What's in Two Names.' In Symposium on the 10th Anniversary of the Chair of Religion and Development, 11 June 2009, edited by Gerrie ter Haar, xvii-xviii. The Hague, Netherlands: Institute of Social Studies ISS.

Burgess, Richard. 2015. 'Pentecostals and Development in Nigeria and Zambia: Community Organizing as a Response to Poverty and Violence.' PentecoStudies 14, no. 2: 176-204.

Bush, Alan J., Craig A. Martin, and Paul W. Clark. 2001. 'The Effect of Role Model Influence on Adolescents' Materialism and Marketplace Knowledge.' Journal of Marketing Theory and Practice 9, no. 4: 27-36.

Chand, Samuel R., and Cecil Murphey. 2003. Who's Holding Your Ladder?: Selecting your leaders - leadership most critical decision. Stockbridge CA: Dream Release Publishing.

de Witte, Marleen. 2003. 'Altar Media's Living Word: Televised Charismatic Christianity in Ghana.' Journal of Religion in Africa 33, no. 2.

Diesendorf, Mark. 2000. 'Sustainability and Sustainable Development.' In Sustainability: The Corporate Challenge of the 21st Century, edited by Dexter Dunphy, Jodie Benveniste, Andrew Griffiths, and Philip Sutton, 19-37. Sydney: Allen \& Unwin.

Emas, Rachel. 2015. 'The Concept of Sustainable Development: Definition and Defining Principles.' Brief for GSDR, The Florida International University.

Fletcher, Adam. 2014. A Short Guide to Holistic Youth Development. Olympia, WA: The Freechild Project, 2014. 
Freeman, Dena. 2013. 'Pentecostalism in a Rural Context: Dynamics of Religion and Development in Southwest Ethiopia.' PentecoStudies 12, no. 2: 1871-7691.

Giddings, Bob, Bill Hopwood, and Geoff O'Brien. 2002. 'Environment, Economy and Society: Fitting Them Together into Sustainable Development.' Sustainable Development 10: 187-196.

Gowing, Linda R., Robert L. Ali, Steve Allsop, John Marsden, Elizabeth E. Turf, Robert West, and John Witton. 2015. 'Global Statistics on Addictive Behaviours: 2014 Status Report.' Addiction 110: 904-919.

Kakwata, Frederick. 2017. 'The Progressive Pentecostal Conception of Development within an African Context of Poverty.' Stellenbosch Theological Journal (STJ) 3, no. 1: 159-183.

Kalu, Ogbu. 2008. African Pentecostalism: An Introduction. New York: Oxford University Press.

Koegelenberg, R. A. 2016. 'The Role of Churches and NGOs in Civil Society - A South African Case Study.' In Anthology of African Christianity, edited by Isabel Apawo Phiri, Kennedy Owino, Dietrich Werner, and Chammah J. Kaunda, 1164-1179. Oxford: Regnum Books Int.

Larbi, Kingsley. 2000. Pentecostalism: The Eddies of Ghanaian Christianity. Accra: SAPC.

Le Blanc, David. 2015. 'Towards Integration at Last? The Sustainable Development Goals as a Network of Targets.' DESA Working Paper No. 141, United Nations Department of Economics and Social Affairs.

Maxwell, John C. 1993. Developing the Leader within You. Nashville: Thomas Nelson Inc.

Munroe, Myles. 2005. The Spirit of Leadership - Cultivating the Attitudes that Influence Human Action. New Kensington, PA: Whitaker House.

Nevin, Elaine. 2008. 'Education and Sustainable Development.' Policy and Practice: Education for Sustainable Development 6 (Spring 2008): 49-62.

Owusu-Ansah, Sylvia. 2016. 'Christianity in Ghana.' In Anthology of African Christianity, edited by Isabel Apawo Phiri, Kennedy Owino, Dietrich Werner, and Chammah J. Kaunda, 594-599. Oxford: Regnum Books.

Owusu-Ansah, Sylvia. 2018. Christianity in Ghana: A Post Colonial History. Accra: SubSaharan Publishers.

Owusu-Ansah, Sylvia, and J. Kwabena Asamoah-Gyadu. 2013. 'Exporting Charismatic Anointing: Power-Packed Evangelistic Crusades and Ministry in African Diasporas.' In Babel is Everywhere! Migrant Readings from Africa, Europe, and Asia, edited by J. Kwabena Asamoah-Gyadu, Andrea Fröchtling, and Andreas Kunz-Lübcke, 131-141. Frankfurt: Peter Lang.

Peterson, Douglas. 1996. Not by Power nor by Might: A Pentecostal Theology of Social Concern in Latin America. Carlisle: Regnum/Paternoster.

Pleiss, Mary K., and John F. Feldhusen. 1995. 'Mentors, Role Models and Heroes in the Lives of Gifted Children.' Educational Psychologist 30, no. 3: 159-169.

Speckman, McGlory. 2016. 'Development, the Bible and the Role of the African Church.' In Anthology of African Christianity, edited by Isabel Apawo Phiri, Kennedy Owino, Dietrich Werner, and Chammah J. Kaunda, 1085-1091. Oxford: Regnum Books Int.

Tracy, Brian. 2014. Leadership. New York: American Management Association.

UNDP. 2001. Making New Technologies Work for Human Development. Human Development Report. New York: Oxford University Press.

United Nations General Assembly. 1987. 'Report of the World Commission on Environment and Development: Our Common Future.' Oslo: United Nations General Assembly. 


\section{Sylvia Owusu-Ansah and Philip Adjei-Acquah}

United Nations. 2002. 'Report of the World Summit of Sustainable Development.' New York: United Nations.

United Nations. 2017. 'The Sustainable Development Goals Report 2017.' New York: United Nations.

United Nations. 2018. 'The Sustainable Development Goals Report 2018.' New York: United Nations.

\section{List of interviews}

Acquah, Raymond, interview by Sylvia Owusu-Ansah, 18 September 2018.

Agyinasare, Charles, interview by Sylvia Owusu-Ansah, 27 October 2018.

Agyin-Asare, Francis (head of Precious TV, Accra), in conversation with Sylvia OwusuAnsah, 20 May 2018.

Agyin-Asare, Francis (head of Precious TV, Accra), interview by Sylvia Owusu-Ansah, 12 October 2018.

Head Teacher, interview by Sylvia Owusu-Ansah, 30 August 2018.

Sekyere, Owusu, interview by Sylvia Owusu-Ansah, 12 January 2018.

Tackie, Robert, interview by Sylvia Owusu-Ansah, 10 October 2018.

Yeji Pastor, interview by Sylvia Owusu-Ansah, 12 January 2018.

Participant 1, Youth Explosion, interview by Precious TV Crew. 27 August 2010.

Participant 2, Youth Explosion, interview by Precious TV Crew. 28 July 2013.

Participant 3, Youth Explosion, interview by Precious TV Crew. 25 August 2014.

Participant 4, Youth Explosion, interview by Precious TV Crew. 27 August 2010.

Participant 5, Youth Explosion, interview by Precious TV Crew. 5 August 2015.

Participant 6, Youth Explosion, interview by Precious TV Crew. 25 July 2006.

Participant 7, Youth Explosion, interview by Precious TV Crew. 27 July 2009.

Participant 8, Youth Explosion, interview by Precious TV Crew. 27 August 2010.

Participant 9, Youth Explosion, interview by Precious TV Crew. 27 August 2010.

Participant 10, Youth Explosion, interview by Precious TV Crew. 15 September 2010.

Participant 11, Youth Explosion, interview by Precious TV Crew. 28 August 2016. 


\title{
15 Distinguished church leader essay
}

\author{
Healing a strained relationship between \\ African Independent Churches and western \\ Mission-founded Churches in Ghana \\ (1967-2017) - the role of Good News \\ Theological Seminary, Accra, Ghana
}

Thomas A. Oduro

\section{Introduction}

African Independent Churches (AICs) have been defined as 'congregations and or denominations planted, led, administered, supported, propagated, motivated and funded by Africans for the purpose of proclaiming the Gospel of Jesus Christ and worshipping the Triune God in the context and worldview of Africa and Africans' (Oduro 2007, 17). Ghana is noted to have recorded the emergence of the first African Independent Church in Africa, south of the Sahara, in 1862 (Opoku 1990, 12-21). In Ghana, they are popularly known and called Spiritual Churches. C. G. Baëta $(2004,1)$ elucidates on the term 'Spiritual Churches':

In Ghana, however, the leaders of these bodies, on the whole, appear to dislike the designation of 'separatist churches' and much prefer to be known as 'spiritual churches'. What is meant is doubtless more correctly described as 'spiritist' than as 'spiritual', but common usage has adopted the latter adjective. In this context the word 'spiritual' has a very special connotation which must be explained. It is intended to signify that, in their worship, the groups concerned engage in various activities which (by their own assertion) are either meant to invoke the Holy Spirit of God, or are to be interpreted as signs of his descent upon the worshippers.

The first three decades of the twentieth century recorded the appearance of precursors of AICs such as the movements led by William Wade Harris and his disciples and admirers which included Grace Tanne, John Nackabah, Kojo Mornor and John Kojoe Baidoe (Debrunner 1967, 269-275). Some AICs were established during that period; most of their leaders were excommunicated from western Mission-founded Churches, while others left them quietly. How the existing churches initially perceived and reacted to the AICs - which was a new breed of Christianity - strained the relationship between the AICs and the 
Mission Churches. How some leaders of the mission used the Good News Training Institute, a theological seminary founded for the training of AICs, to heal the wounded relationship is the focus of this essay.

\section{The relationship between the AICs and western Mission- founded Churches in Ghana}

The prominence of the AICs came to the fore from the 1950s. The causes of their growth and popularity have been observed by two scholars. According to Opoku

To a large extent, the occurrence of the independent churches is an attempt by African Christians to find 'a place to feel at home', not only in terms of worship but also in the whole expression of religion. In the independent churches one sees an attempt to Africanise Christianity, and in this exercise there is evidence of a fusion of elements of both traditional culture and Christianity, which removes the feeling of strangeness many an African feels at the missionary-led churches.... These new religious movements can be seen as attempts to create or establish 'new societies', which may be substitute for the old life, but which at least provide fellowship, security, and some sanctions and guidance for living in modern Africa.

To James Anquandah, 'independency is really an extension of orthodoxy, the result of orthodox failure to test the spirit of gifted members of their flock and to utilize these gifts to edify the church' $(1990,24)$.

Concerning the growth and influence of the AICs, David Beckmann, who wrote about Eden Revival Church, a Ghanaian African Independent Church, notes, '[b]y 1970 there were at least 100 such churches in Accra, and about 200 others scattered throughout the country. Probably 300,000 or 400,000 Ghanaians have firmly committed themselves to Independent Churches, and at least twice as many again have in some way been influenced by the movement' $(1975,11)$. Hudsen and Mertens, Roman Catholic researchers, comment on growth of the AICs in Accra in the 1970s:

In a town like Accra the number of such places of worship may well be close to a thousand. This estimate is based on the known addresses of 2-300 Spiritual Churches in Accra, many of which have several churches. With an average of 40-50 attendants, the total may reach 50,000, which is probably more than or as much as that of the established Churches combined.

(n.d., 260)

Leaders and members of the Mission Churches became perturbed about the growth and popularity of the AICs when their members left in droves to become members of these new movements. Some of the prominent members of the Mission Churches patronised their ministries surreptitiously, as stated by Anquandah: 
Before the independent churches began expanding and gaining recognition, many people including members of the older churches flocked to independency, often under cover of darkness, in Nicodemus fashion, seeking solutions to their problems. Since the attainment of political independence in Ghana, independency has grown out of its prayer-group and temporary nature and assumed fully-fledged church status.

Commenting on the eight-point findings of a Commission set up by E. M. L. Odjidja, ex-moderator of the Presbyterian Church of Ghana, on why Spiritual Churches grew rapidly in Ghana during the 1970s, L. S. G. Agyemfra states, 'whether the established churches [i.e. the mission churches] like it or not their adherents desert them to worship in churches which satisfy their spiritual demands' (n.d., 28). Regarding the defection of Roman Catholic members to the AICs, Hudsen and Mertens conclude that, 'Spiritual Churches draw an increasing number of Catholics, among them educated and young people' (n.d., 40). As a result, many leaders and members of the Mission Churches accused the AICs as 'sheep stealers'; i.e. churches who take delight in proselytising members of other churches rather than reaching out to the unreached.

The Mission Churches, therefore, adopted many strategies to discourage their members from becoming members of or patronising the activities of the Independent Churches. Prominent among the strategies were that of sarcasms and insults. Their spiritual emphasis earned them the pejorative name 'Spiritual Churches'. Kwabena Asamoah-Gyadu, who uses the Akan translation of the Independent Churches, Sunsum sore, i.e. Spiritual Churches, notes

It is worth pointing out here, however, that the exaggerated portrayal of the Sunsum sore as a societal menace has been reinforced through television drama and local Ghanaian films. This has not helped their cause. In such TV shows and films, the prophets are always depicted as faking spiritual possession and divine communication through which they dupe and cheat unsuspecting clients.

$(2005,93)$

Some Mission Church leaders insulted African Independent Church pastors indiscriminately and openly by calling them 'religious crooks and swindlers who are only out to cheat not only the individuals but also the Government and the nation' (Assimeng 1989, 132). From a Roman Catholic perspective, a parish priest called African Independent Church leaders tricksters and deceivers (Hudsen and Mertens n.d., 25). Consequently, many Christians did not consider these new churches genuinely Christian. When the National Liberation Council, a military government, invited C. K. Wovenu, leader of the Apostles Revelation Society, an African Independent Church, to preach during the rededication of Christiansborg Castle, which was then the seat of government in 1966, the Christian Council of Ghana protested vehemently because 
'the Christian Council did not consider Wovenu a true representative of the Church' (Pobee 1991, 93). To most people, AICs worship centres were perceived as Christo-demonic worship centres; places where demons were worshipped under the pretext of worshipping Christ (Asamoah-Gyadu 2005, 175). The perception of the Roman Catholics was not different from the Protestant Churches. 'It has been stated already that the Catholic clergy and the Catholic community in general have a rather negative attitude towards the Spiritual Churches' (Hudsen and Mertens n.d., 36). As a result, when the Pentecostal/Charismatic Churches began emphasising the ministry of delivering people from demonic entanglements, those who have ever attended a Spiritual Church were automatically perceived as candidates of deliverance from demons (Asamoah-Gyadu 2005, 175). AsamoahGyadu captures the image of the AICs in Ghana in the 1970s thus:

The negative image is evidenced by certain ludicrous epithets that these churches have attracted. Many commonly refer to them as 'pray-for-me', 'kill the light' ... 'holy water' or abo-nsamu (hand-clapping), all in a bid to portray Sunsum sore Christianity as contrived and their prophets as fraudulent, or religious impostors who indulge in false prophecy, fortune-telling, lying visions and exploitative divination.

$(2005,94)$

The AICs, on the other hand, reacted by calling the Mission Churches 'churches without the Spirit of God'. The testimonies of some Mission Church members who defected to join the Independent Churches stressed the perception that the former were places where the Spirit of God was fast asleep.

In the Methodist church there was no healing, our dreams were never explained or interpreted, we never had [prophetic] messages. Nothing was done to heal us of our diseases and no word at all was said about the future. There was nothing spiritual about the Methodist Church.

(Wyllie 1980, 128)

AICs disdained churches that did not emphasise prayer, fasting, exorcism, healing, seeing of visions and prophetic utterances. 'They [i.e. the AICs] sometimes preach vehemently against the older Churches [i.e. the mission churches] and accuse them of lack of faith and of the Spirit' (Hudsen and Mertens n.d., 35). In fact, the hatred of the AICs towards the Mission Churches precluded them from having any ecumenical contact with them (Hudsen and Mertens n.d., 35).

The AICs boasted about the spiritual power they exhibited. This can be inferred from the statement of Prophet Jehu Appiah of the Musama Disco Christo Church when he said, 'politically, we are the harmless; economically, we are feeble; socially, we are downtrodden; but spiritually, we are more than giants' (Wyllie 1980, 105). Such was the nature of the relationship between the AICs and other Christian communities during the first two decades following the independence of Ghana. 


\section{The turn of events}

Edwin and Irene Weaver, a Mennonite missionary couple, were posted to Uyo in Eastern Nigeria to serve some Independent Churches who requested missionary directives from the Mennonite Mission Board in the USA. When they arrived in Nigeria in 1959, they bumped into antagonism between the Independent Churches and western Mission Churches but they sought collaboration from the leadership of Eastern Nigeria Christian Council and the African Independent Church leaders to quell the hostility among the Nigerian Christians (Weaver and Weaver 1970, 9-115). The Weavers had to be evacuated from Nigeria in 1967 to the USA during the Nigerian civil war (1967-1970). Two years later the Weavers returned to West Africa via Freetown, Sierra Leone, where Apostle E. A. Adejobi, Primate of the Church of the Lord (Aladura), an African Independent Church founded in Nigeria (Turner 1967, 2-207; 1967, 2-369), met them, apparently, to persuade them to establish a theological seminary in Lagos to train leaders of his church. Though the intention of the Primate did not become a reality, he recommended the Weavers to all Aladura (i.e. praying people) congregations along the coast of West Africa (Weaver and Weaver 1975, 8-12). Edwin and Irene Weaver finally decided to settle in Ghana. The arrival in Ghana of Edwin and Irene Weaver marked the founding of the Good News Theological Seminary in Accra, Ghana, then known as Good News Bible Classes. It was later known as Good News Training Institute in 1971 and Good News Theological College and Seminary in 1996. Edwin and Irene, aided by Archdeacon Solomon Krow of the Church of the Lord (Aladura), brought together

About twenty-five leaders of the various church organisations, patrons and matrons, prophets and prophetesses, seers and seeresses, laymen of all kinds, and most important, both Bishop Krow and Mrs. Krow, enrolled.

(Weaver and Weaver 1975, 20)

They replicated the founding of a bible school in Uyo by beginning a Bible study programme known as 'Good News Bible Classes' at the choir loft of the Church of the Lord (Aladura), popularly known as 'Nima Temple' at Nima, a suburb of Accra which is predominantly inhabited by Muslims. The students met on Mondays, Tuesdays and Fridays from 5 p.m. to 7 p.m. The first lecturers were Mennonite expatriates in Ghana - Edwin and Irene Weaver, and Willard and Alice Roth. Later, 14 church leaders representing 10 AICs who formed the Accra Leaders Fellowship rented a room in the Accra Community Centre to study the Bible. The primary goal of the Bible classes was to provide a forum for training Ghanaian leaders and members of the Independent Churches in biblical and ministerial matters since prior to the efforts of Edwin and Irene Weaver, they had no theological institution to offer such systematic training. 


\section{Strategies of healing the strained relations between the AICs and western Mission-founded Churches}

Edwin and Irene Weaver, the Mennonite missionaries, were concerned about the deep fracture in the relationship between the AICs and other Christian communities in Ghana. Describing the nature of the relationship as 'deep-rooted antagonism' (Weaver and Weaver 1975, 77), the Weavers decided to redefine the purpose of theological education. To the Weavers, theological education is not just to enhance the knowledge of the learners about God, the church and theology as it was the norm in most theological institutions; it is also to ensure peace and cohesion among learners and teachers in a pragmatic Christian manner. Theological education is not just teaching learners about the dynamics of peacemaking and encouraging them to undertake trips to observe peacemaking efforts at places where there are socio-religious conflicts. Theological education, to the Weavers, must be a tool of ensuring practical peacemaking in factional societies. Knowing that 'dialogue and understanding has to begin with the leaders of the missionfounded churches if progress is to be made in reconciliation between the indigenous and mission churches' (Weaver and Weaver 1975, 13), the Weavers devised a three-way strategic approach to the problem with the aim of healing the estranged relationship. The outline of the strategy was

to contact and develop personal relationships with indigenous churches and their leaders; to do the same with mission-founded churches and their leaders; [and] to encourage dialogue and understanding between the mission-founded and indigenous churches themselves.

(Weaver and Weaver 1975, 77)

Edwin and Irene admitted the enormity of the estrangement by stating that 'attempting to relate to both groups was risky. We were under suspicion by both sides, always vulnerable to misunderstanding' (Weaver and Weaver 1975, 77). In spite of this sinister perception they continued to bring peace between the AICs and the Mission Churches.

\section{Implementing the strategies}

The three-way strategic plan was implemented through many forms, even after the Weavers left Ghana to return to the USA for good. The implementation took the following forms: publication in a monthly magazine. The Weavers influenced the editor of the Christian Messenger, a monthly magazine of the Presbyterian Church of Ghana, to publish a series of articles entitled 'Introducing the Spiritual Churches' (Weaver and Weaver 1975, 83). The articles threw more light on some doctrines, liturgies and the uniqueness of the AICs. Convincing some church leaders and synods of Mission Churches. Edwin and Irene were invited to the synods of some Mission Churches to speak on the relevance of the spiritual churches. The Methodist Church, for instance, allowed the Weavers to 
meet a special study committee to work on a framework of relating healthily with the AICs (Weaver and Weaver 1975, 83). Making arrangements for Mission Church leaders to teach at some AICs.

When the then secretary of the Methodist Church, Rev. I. K. A. Thompson, heard about the Good News Bible Class, he expressed a desire to teach the class, so an arrangement was made for him to teach series of biblical topics at the Holy Church of the Lord (Ghana), an African Independent Church (Weaver and Weaver 1975, 87). Prior to that, students of the Trinity College, now Trinity Theological Seminary, were assigned to teach Sunday school classes at some AICs worship centres (Weaver and Weaver 1975, 42-45). The seminary has kept a close relationship with Trinity Theological Seminary since then.

\section{Inter-church dialogue/conversations}

Two inter-church meetings - on 29 November 1969 and 7 September 1970 - were held at the University of Ghana on the theme 'Avenues of Cooperation between Indigenous Churches and the Historical Churches in Ghana'. The former, which was attended by about fifteen persons from the university, was chaired by Professor Kofi Asare Opoku (Weaver and Weaver 1975, 89). Leaders of the AICs, the Mission Churches and scholars of the department for the study of religions at the University of Ghana, Legon, met quarterly from 1971 to 1973 to dialogue on their common beliefs, ethos and differences. The nature of the conversation was that it was a forum, a setting, a meeting place for dialogue providing the opportunity for churches to learn and know one another (Weaver and Weaver 1975, 92). The maiden dialogue, which was attended by sixty persons representing the Pentecostal Association [an ecumenical group of the AICs], Christian Council of Ghana [an ecumenical body of Protestant Mission Churches], as well as both established and independent Spiritual Churches (Weaver and Weaver 1975, 90) was held on 25 May 1971 at the Accra Community Centre. The purpose of the meeting was 'to give opportunity for leaders of all churches to become better acquainted with one another and to provide a neutral setting for discussion and dialogue on subjects of common concern' (Weaver and Weaver 1975, 90). Prof. C. G. Baëta of the University of Ghana, who was also a pastor of the Evangelical Presbyterian Church, a scholar of religion and a researcher on AICs, chaired the maiden interchurch dialogue/conversation. He clarified the aim of the meeting thus: 'This is not a matter of anyone joining another, but simply an opportunity to get together informally to exhort and encourage one another' (Weaver and Weaver 1975, 90). In his concluding remarks, Prof. Baëta stated

We have done a lot of important work this morning. We have shown one another that we do not want to live in isolation, but whatever our differences, we desire to know one another better. Although we are engaged in a common task, we affirm that the task has many forms and one person or one body dare never monopolise God's mission in the world.

(Weaver and Weaver 1975, 92) 
The second inter-church conversation was held in 1972, by which time the Weavers had left Ghana. Themes discussed in all the conversations between 1971 and 1973, according to the Weavers' recording of concerns and questions asked by leaders of both the AICs and Mission Churches, might have included: reconciling Independent Church leaders and the Mission Churches from which they were expelled, having a better understanding between churches, pulling down walls of prejudice that divide churches, reconciling AICs which were at loggerheads within their ranks, establishing theological training for AICs leaders and members, having a better way of administering churches, acceptance of AICs for what they are and their own understanding of Christianity (Weaver and Weaver 1975, 80-84). In all, seven conversations were held every quarter within the period 1971-1973.

\section{Continuation of the healing process in a post-Weaver era}

Asking lecturers from the Mission Churches to teach at the seminary. Administrators of Good News Training Institute, the bible school that was established in 1971 and now called Good News Theological Seminary in Accra, continued the process of healing the strained relationship after the departure of Edwin and Irene Weaver from Ghana in 1971. The establishment of the seminary was a collaborative effort by leaders of the Christian Council of Ghana, a few observers from the Catholic Church and leaders of AICs. Nine churches initially sponsored the seminary. The AICs were Faith Brotherhood Praying Circle, Sacred Miracles Clinic Fellowship, The Church of the Lord (Ghana), Divine Healing Church of Christ, Eden Revival Church, Twer Nyame (Divine Fellowship), Church of the Messiah and Church of Bethel. The non-African Independent Church was the Lutheran Church of Ghana. Many lecturers from the Mission Churches were asked to teach on a parttime basis at the Good News Theological Seminary, after its formal inauguration on 6 November 1971. The lecturers inter alia came from the Methodist Church of Ghana, the Presbyterian Church of Ghana, the Roman Catholic Church, the Anglican Church, the Seventh Day Adventist Church, the Lutheran Church, the Mennonite Church and the Baptist Church. One of the early lecturers was Ephraim Amu, a Presbyterian Church of Ghana musician, poet and nationalist par excellence (Agyeman 1988, 11-188; Laryea 2012, 8-412). The first AIC pastor to become a board chairperson of the seminary was Bishop Isaac Wontumi, leader of the Church of Melchizedek.

Employing Mission Church lecturers to teach alongside those from the AICs at the seminary has become a normative practice. The purpose has been to allow the lecturers and the students to know more about one another and their denominations for mutual respect and recognition. The AICs felt a sense of acceptance into the Christian community when Mission Church leaders occasionally worshipped with them, preached at their functions and spoke about the need to register at the seminary. It was at such worship setting of the Church of the Lord (Brotherhood), Accra, in 1980 when the writer of this chapter, after listening to Ms Erma Grove, a Mennonite missionary speaking about the 
seminary, enrolled as a student of the seminary. The ecumenical setting of the seminary has become a solution to the suspicion, allegations and marginalisation of AICs and a great cause of deeper fraternity.

In 1983 the board of the seminary headed by Rev. Dr. Sam Prempeh, a Presbyterian and then the Principal of Trinity College, decided to train some AIC alumni of Good News Training Institute to become lecturers of the seminary. Rev. Ezekiel Nartey of the Church of Melchizedek and the writer were selected to further their education at Christian Service College in Kumasi. Their admission in the college in 1984 was considered as a great feat since they were the first members of Independent Churches to be enrolled in the prestigious evangelical college since its establishment in 1974. The healing process continued at the college as a result of interacting and studying with students and lecturers from the mission churches and Pentecostal/Charismatic Churches.

\section{Administering the seminary by AICs and Mission Churches}

The Board of Governors/Governing Council of the seminary has been composed of both leaders of the AICs and the Mission Churches - in line with the process of healing their soured relationship. The Steering Committee of the nascent seminary in 1970 were James R. Anquandah (then an AIC member), Kwesi B. Ellis (then a Methodist minister) and W. E. Roth (a Mennonite missionary). Some prominent board chairpersons have been Prof. C. G. Baëta of the Evangelical Presbyterian Church, Rev. Dr Samuel Prempeh of the Presbyterian Church and Rev. Dr Asante-Antwi of the Methodist Church, and Mr James Amoah, a Baptist. Rev. Prof. Emmanuel Martey, the immediate past moderator of the Presbyterian Church of Ghana, was, prior to his elevation to the position of a moderator, the Chairman of the Academic Committee of the seminary. Principals/ presidents of the seminary used to be appointed from the Mennonite Board of Missions and the Evangelical Lutheran Church in America (ELCA) from the inception of the seminary in 1971 to 1992 when the writer, an AIC member, was appointed to be the first AIC president of the seminary. Chairing the highest decision-making body of the seminary has given the different churches the opportunity to continue the process of healing the strained relationship, find solutions to the challenges and heartbreaks while ensuring the seminary's growth.

\section{Writing of AICs' histories and biographies of their leaders}

The Academic Board of the seminary during the 1990s realised that one of the key factors of the soured relationship between the AICs and other Christian communities in Ghana has been either the partial knowledge or lack of knowledge of the history, doctrines and liturgies of the Independent Churches. Therefore, as an academic policy, students are mandated to write the history of an AIC before they are graduated. The Journal of African Christian Thought, vol. 3, no. 2, December 2000 published some of these histories. There are dozens of histories yet to be published. 


\section{Sustainable development programmes}

The present administration of the seminary, headed by the writer, in continuing to heal the vestiges of broken relationship between the different church families in Ghana, decided to use a socioeconomic method to bring together members of different denominational backgrounds while being equipped with skills to earn a decent living. Helena Mananu-Hooper, one of the lecturers of the seminary who is an AIC pastor, was supported by the ELCA to further her education in theology, evangelism and development at the Wartburg Theological Seminary in Dubuque, IA, USA. ELCA supported the seminary to establish a Skills Development Training Centre at Ziope in the Volta Region of Ghana in 2015. Another centre was established at Wudzedeke also in the Volta Region in 2017. The two centres, which serve 58 communities in the Agotime-Ziope District, were chosen because of the polarity of relationship among the churches, the low-income level of the inhabitants and the willingness of the traditional rulers to work closely with the seminary. The purpose, therefore, is to empower the participants to reduce abysmal poverty levels and promote ecumenical relationship. Participants are from AICs, the Roman Catholic Church, the Evangelical Presbyterian Church, Assemblies of God, some Apostolic Churches, the Presbyterian Church of Ghana and the Global Evangelical Church. Some of the participants come from nearby towns in the Republic of Togo; others are Muslims. The two centres are managed by select groups of participants from the various churches and the Muslims.

Activities at the centres include running of seminars and workshop on topics such as the church and investments, empowerment of women and men, particularly widows and widowers, and church growth and leadership. Another activity is about agricultural development. The seminary has purchased a 20-acre demonstration farm at Ziope. Maize, tomatoes, pepper, cassava, potatoes and other seed crops are planted with the guidance of agricultural extension officers. Farmers at the centres are taught proper and new ways of planting seeds that yield great harvests. In addition, high-yielding seeds and fertilisers are distributed to farmers to plant on their individual farms. Another activity is the hiring of wellington boots, spraying machines and other tools of farming to the farmers. The fifth activity is the training of some of the participants in the weaving of kente, batik and tie-dye. Lastly, the seminary has opened an Information and Communication Technology (ICT) Centre for the youth and schoolchildren at Ziope. The proximity of the ICT Centre has saved users the hazard of travelling 31 kilometres to Ho, the regional capital, to have access to the internet. Besides, the users know that the centre belongs to the ecumenical body of the villages.

\section{The results}

The results of the wound-healing ministry of the Good News Theological Seminary have been phenomenal. The most prominent has been a degree of respectability and mutual recognition of the former 'warring' factions. The AICs 
have realised that they are not the epitome of spirituality and spiritual power. They have imbibed the western style of administering churches, sermon preparation and delivery and systematic ways of studying the Bible. The AICs have benefited from the immense theological and ministerial knowledge and expertise of the Mission Churches and other Christian communities. As a result, some of their alumni furthered their studies to postgraduate levels in tertiary institutions both in Ghana and abroad - five out of the ten lecturers of the seminary, including the writer, are scholars of AICs with graduate and postgraduate degrees. AICs' choirs are invited to participate in the annual choral music competitions on TV3 dubbed 'Celebrations'. The Choir of Apostles Revelation Society (ARS), Ashaiman congregation participated in the 2015 version of the TV 3 choral competition. African Independent Church leaders have been included in the planning and participation of national events such as National Day of Prayer. At the academic level, Mission Church tertiary institutions such as the Trinity Theological Seminary and the Akrofi-Christaller Institute of Theology, Mission and Culture periodically invites the writer to review and or grade Master of Theology dissertations written by students of the respective Mission Church institutions of higher learning. The writer has also been invited to jointly write a book with Mission Church scholars (King et al. 2008; Oduro et al. 2008).

The Mission Churches, on the other hand, have also realised that God can use any person or group of persons in many ways irrespective of the person or the group of persons' low education or lower social status. Leaders and members of the Mission Churches have benefited from the spiritual gifts of the AICs. Unlike the previous times when some of their members sneaked to receive prayers or to find solutions to their spiritual challenges, these days they patronise the spiritual services of the Independent Churches openly. There has been an upsurge of 'spiritual renewals' in the Mission Churches. Sanctioning members who 'flirt' with the AICs has now become a thing of the past. They have appreciated the introduction of some important elements to African Christianity by the AICs. Such elements, such as clapping of hands, dancing, beating of drums, congregational prayers, healing, lively worship have all been integrated to their corpus ministries. As a result, they have regained some of their members who joined the AICs while enjoying lively African worship. Most Christians have had the privilege of knowing and understanding the ministries and doctrines of the AICs. There is now more talk about the need for contextualisation in the Mission Churches.

When participants of the Skills Development Project meet, they forget about their denominational linkages and their doctrinal differences; they concentrate on learning new skills to improve their standard of living. The more often they meet the more their denominational shades fade into oblivion. They see one another first as fellow human beings created in the imago Dei before realising their denominational colouration. At the pavilions at Ziope and Wudzedeke I saw the learners happily doing their assignments and during break singing together. During graduation ceremonies the chiefs, elders of outlying villages, 
pastors and Imams all congregate at the graduation ground to sing and dance joyfully. It was a great joy to witness the first graduation ceremony of those who learned the skills of weaving kente and doing tie-dye on 5 August 2017 at Ziope. The joy demonstrated by the 51 graduating students cut across tribal, social, denominational, religious, national, cultural and ethnic barriers. The culminating fact is that theological education, when properly defined and used, heals wounds and reconciles people of all ages and denominations in a pragmatic manner.

\section{References}

Agyeman, Fred. 1988. Amu The African: A Study in Vison and Courage. Accra: Asempa Publishers.

Agyemfra, L. S. G. n.d. Church Union: An Opinion. Accra: Waterville Publishing House.

Anquandah, James. 1990. 'The Ghana Independent/Pentecostal Movement', In The Rise of Independent Churches in Ghana, edited by Asempa Publishers. Accra: Asempa Publishers. 27-33.

Asamoah-Gyadu, J. Kwabena. 2005. African Charismatics: Current Developments within Independent Indigenous Pentecostalism in Ghana. Achimota: Africa Christian Press.

Assimeng, Max. 1989. Religion and Social Change in West Africa. Accra: Ghana Universities Press.

Baëta, C. G. 2004. Prophetism in Ghana: A Study of Some Spiritual Churches. Achimota: Africa Christian Press.

Beckmann, David M. 1975. Eden Revival: Spiritual Churches in Ghana. St. Louis: Concordia Publishing House.

Debrunner, Hans. 1967. A History of Christianity in Ghana. Accra: Waterville Printing House.

Hudsen, C. and Rev. Fr. Mertens. n.d. Survey of the Church in Ghana. Cape Coast: Catholic Mission Press.

King, Roberta, Jean Ngoya Kidula, James R. Krabill, and Thomas Oduro. 2008. Music in the Life of the African Church. Waco, Texas: Baylor University Press.

Laryea, Philip K. 2012. Ephraim Amu: Nationalist, Poet and Theologian (1899-1995). Akropong-Akuapem: Regnum Africa.

Oduro, Thomas. 2007. Christ Holy Church International: The Story of an African Independent Church. Minneapolis, Minnesota: Lutheran University Press.

Oduro, Thomas, Hennie Pretorius, Stan Nussbaum, and Bryan Born. 2008. Mission in an African Way: A Practical Introduction to African Instituted Churches and Their Sense of Mission. Christian Literature Fund and Bible Media.

Opoku, Kofi Asare. 1990. 'A Brief History of Independent Church Movements in Ghana since 1862.' In The Rise of Independent Churches in Ghana, edited by Asempa Publishers. Accra: Asempa Publishers, 12-21.

Pobee, John S. 1991. Religion and Politics in Ghana. Accra: Asempa Publishers.

Turner, H. W. 1967. History of an African Independent Church I: The Church of the Lord (Aladura). Oxford: Clarendon Press.

Turner, H. W. 1967. African Independent Church II: The Life and Faith of the Church of the Lord (Aladura). Oxford: Clarendon Press.

Weaver, Edwin, and Irene Weaver. 1970. The Uyo Story. Elkhart, Indiana: Mennonite Board of Missions. 
Weaver, Edwin, and Irene Weaver. 1975. From Kuku Hill: Among Indigenous Churches in West Africa. Indiana, Elkhart: Institute of Missionary Studies of the Associated Mennonite Biblical Studies.

Wyllie, Robert W. 1980. Spiritism in Ghana: A Study of New Religious Movement. Missoula, Montana: Scholars Press.

Yoder, R. Bruce. n.d. 'Weaver, Edwin (1903-1989) and Irene [Lehman] (1910-): Pioneer Missionaries Among African Initiated Churches.' Boston University, School of Theology. Accessed 14 June, 2019. www.bu.edu/missiology/missionary-biography/w-x-y-z/ weaver-edwin-1903-1989-and-irene-lehman-b-1910/. 
$\Longrightarrow$ Taylor \& Francis Taylor \& Francis Group http://taylorandfrancis.com 


\section{Part IV \\ Perspectives from \\ Burkina Faso}


$\Longrightarrow$ Taylor \& Francis Taylor \& Francis Group http://taylorandfrancis.com 


\title{
16 Distinguished church leader essay
}

\author{
Partnerships for female education in \\ Burkina Faso - perspectives from \\ Evangelical Churches and FBOs
}

\author{
Philippe Ouedraogo
}

\section{Introduction}

Many obstacles - historical, social, cultural/religious and economic - have hindered, and continue to hinder, the development of girls' and women's education in Burkina Faso. However, churches and faith-based organisations (FBOs), especially evangelical institutions like the Assemblies of God Church and Christian FBOs such as the Association Evangélique d'Appui au Développement (AEAD), have shown, and are continuing to show, innovative ways to improve girls' and women's education in the country.

Since the beginning of the 1990s, there has been recognition that improving the education of both girls and women in the developing countries of the world is essential for the socioeconomic development of these countries. Not only does female literacy lead to improved healthcare, better family life expectancy and improved motivation in employment, it also leads to greater confidence among women, who are as a consequence more likely to become involved in the political decision-making processes, locally or nationally. That is why targets for girls' enrolment in schools and improvements in female literacy have become key aspects of the Sustainable Development Goals (SDGs).

In this essay, I present the experiences of Evangelical Churches and Christian NGOs in female education in Burkina Faso. By making use of in-depth narrative interviews conducted in an inquiry into this topic in 2006, I allow the voices of key actors in female education, educators and pastors to be heard. In the second part of the essay I describe the form of partnerships for education between evangelical organisations and other faith actors at the local and national level in Burkina Faso. Moreover, I reflect on the role of international organisations and the type of partnerships that are necessary to improve the collective effort of improving female education in contexts such as Burkina Faso. 


\section{Experiences of Evangelical Churches and Christian NGOS in female education in Burkina Faso}

\section{Assemblies of God}

I interviewed a senior staff member of the Assemblies of God Church who worked in formal education for over 40 years to hear his opinion on why the church got involved with female education. The Assemblies of God Church came to Burkina Faso in January 1921. Formal education and transcribing one of the main national languages (Mooré) was one of the primary activities of the missionaries. The Assemblies of God Church promoted formal and non-formal education. Later, those who benefited from such education also set up schools and organisations to support the church vision for the benefit of the nation. According to Innocent Kientega, an educationalist of the Assemblies of God Church, this has to do with our social context.

In our context one prefers to invest in the life of boys because the boy will carry on bearing the name of the family. Also, because of the limited resources, if one has to choose between educating a boy and a girl, one will choose to educate the boy. This is why to remedy this imbalance the church decided to care for those that were seemingly neglected by society, that is girls' education. I think the church was right in opening girls' schools.

For Kientega, education has more impact on girls than boys because they are the mothers, responsible for their family, and struggling to impart value they have learnt.

On the question of why the Assemblies of God started schools, Pastor Simporé, a senior leader of the church, explains:

I believed this was led by God. It was in 1921 that the gospel came to Burkina by the Assemblies of God missionaries. From 1921 to 1948 we have no information about evangelical schools. I was not born then. But I believe God wanted the church to have a good foundation before talking about schools. From 1948 God allowed Pastor Pierre Dupret from France to open the schools. We were told that he received that vision from God to open schools though not all of his board members agreed with him in this project especially concerning the opening of the secondary school. He even showed us the place where he said God spoke to him to open the schools. He was convinced of that idea. It seems that God was preparing people for the church's future generation. With the progress of today the church will need capable leaders. At the time the primary school was opened there were not many intellectuals in the church, apart from the American missionaries. The gospel is for all the population and the church needed intellectuals. Those intellectuals could also reach their peer groups as well. That is my opinion. Today we have brothers and sisters with different levels of education who can reach others both 
intellectually and spiritually. There are other intellectuals who did not go through the evangelical schools, but the majority of those who impacted the church came from the evangelical schools.

(interview Simporé 2006)

Flavien Tapsoaba, a pastor in Ouagadougou and General Treasurer of the Federation of Evangelical Churches and Missions as well as the former president of the Apostolic Church in Burkina Faso, joins the above voices explaining the reasons why the church should promote girls' education:

After leading the church for many years, the vision I had was to prepare future leaders by setting up schools. I had the privilege of opening the first schools of the Apostolic Church in Burkina and led them for twenty-one years. Then I opened another school called Raoul Foleraux that also is twenty-five years old. The motivation behind all this is to prepare future leaders of the church to cope with the growing capacity of the church. In order to do this, we need to prepare the coming generation. The Bible says 'teach the child the way he should follow and when he becomes older, he will not forsake it' (Prov. 22:6). I am the product of the evangelical school run by Pastor Pierre Dupret of the Assemblies of God. I did not come from a Christian background but going through that school was an opportunity for me to become what I am today. Referring to the importance of evangelical schools, whether they are opened by the church or individual members we see the importance of that ministry. This is why we promote evangelical schools to run the official teaching programme. But alongside that programme we have the right to share the Good News of Jesus Christ. Such a message will help the children become able and responsible good citizens of tomorrow. These children will be the future church leaders and by setting examples of good leadership and citizenship they will bring their contribution to the development of Burkina Faso. These are the main reasons that motivate us in setting up evangelical schools.

(interview Tapsoaba 2006)

All these leaders who were interviewed benefited from the education provided by the Evangelical Church and are now promoting the establishment of new schools and Christian organisations which promote literacy and socioeconomic development for girls and women. Tapsoaba outlines the objectives of the church's educational work:

Our evangelical schools are a means by which more children will hear the word of God and as a pastor we want the number of Christians to increase. If the young people are not well trained intellectually and spiritually, they will not be in position to face many challenges of life awaiting the church and the entire nation. 
However, Assemblies of God's activities for the promotion of girls' education in Burkina Faso are not without difficulties:

It depends on where you are from in Burkina Faso. Basically, in the central plateau people understood that sending the boy to school was especially a good investment. But in areas such as the Northern region, North-East and West not all parents see the importance of sending their children to school. These obstacles are also seen with the geographical location of the school. One obstacle is that many of these children leave the school without being prepared to integrate in life. We then need to think about secondary schools that will allow these girls and boys to increase their educational level and be better prepared to find gainful employment. Some education provided such as the Assemblies of God Church, AEAD and other Christian NGOs have set up secondary school where girls and boys can study together. In this school, there are opportunities to learn life skills to prepare them to enter the job market. The church was not an obstacle to girls' education. On the contrary during the missionary period girls' homes were opened to receive anyone who had difficulties and needed help. However, the church still needs to do more for girls.

(interview Tapsoaba 2006)

\title{
The contribution of FBOs to female education
}

\begin{abstract}
AEAD
The AEAD, the organisation of which I am the director, is an FBO which has worked in Burkina Faso since 1992. Its vision is to 'improve life through the love of God'. AEAD's mission stands for creating and developing integral approaches to improve life through education, training, socioeconomic development and evangelism. In the education section of AEAD, formal and nonformal education are combined in an integral approach to give opportunities for children and adults to receive appropriate education in the Centre West, Centre and Northern regions of the country. During the 2016/2017 academic year, AEAD was running 11 formal schools, reaching 2,102 girls and boys. Some 1,000 persons are cared for in non-formal education centres where, through adult literacy and special education programmes, men and women are exposed to an education that enables them to contribute to their own development.

AEAD seeks to find innovative ways of working from grassroots communities' point of view to fight against poverty of all sorts, whether economic, social or spiritual. Non-formal education allows women and men to learn how to read and write in their mother tongue and use the acquired knowledge to improve matters such as agriculture, basic health, gender, entrepreneurship, and cultural and religious values at community level.

In its integral approach, AEAD intends to contribute to overcoming the root causes of girls' and women's difficulties in education by assisting communities to
\end{abstract}


have access to clean water, by engaging in environmental protection with tree planting and anti-erosive systems, by contributing to the increase of food production and by running a medical centre which provides support to HIV/AIDS victims. AEAD works peacefully in a multifaith context in Burkina Faso, remaining true to its nature in supporting the capacity building of the local churches, which in turn are agents of a community's transformation.

\section{ANTBA}

Another Christian NGO engaged in educational work in Burkina Faso is the National Association for Bible Translation and Literacy (ANTBA). It is responsible for a large portion of the syllabus used in the literacy classes in the church literacy centres. According to Sabine Compaoré, a financial officer of ANTBA, the target groups in their ministry are girls, women and children that did not have the opportunity to go to formal school. Each year they run over 500 adult literacy courses across the country. ANTBA translates the Bible into local languages. The organisation sees literacy programmes as a key necessity to enable people to read the Bible in their mother tongues. What benefit would it bring if they translated the Bible and brought it to a group of people who do not know how to read? Their literacy programmes actively contribute to development. Moreover, the different literacy programmes contain modules on civic life and health-related issues. Hence, they connect the educational component to capacity building on other dimensions of development as well.

It is interesting how Sabine Compaoré describes the work of the organisation in relation to its Christian identity:

ANTBA is in partnership with the government Department of Literacy especially with the production of the national curriculum (Institut National d'Alphabétisation, INA). We also have our own syllabus. ANTBA can use the government syllabus but it has its own that it uses in their programme. We have the right to use our syllabus. As a Christian organisation the content of our syllabus comes from the Bible. When we partner with others in literacy, we use our own syllabus because we pursue an objective that is to evangelise and this has resulted in people accepting Jesus Christ during the literacy programme by using our syllabus. We do not have any problems with Christian partners but with others we share with them the way we work, and this is accepted. Our organisation is well appreciated by the government who evaluates the work we do in literacy and sees the results. The government looks at us as a credible partner in non-formal education to the point that we have benefited from the public funds for literacy and the support from UNICEF... The government does support us and invites other partners to support us in our effort in providing literacy classes and training to the population. 


\section{Partnerships for female education}

The need for quality education is universally acknowledged by governments, international organisations and NGOs around the globe. Many organisations have recognised the need for partnerships with civil organisations to participate both in the planning and the implementation at grass-roots level. However, very few recognise the role played by churches and FBOs. It sounds as if national and international organisations are avoiding an important piece of the puzzle that will keep local and national governments accountable. These groups, such as registered Christian FBOs, are viable partners who are acting as advocates for access to and quality in education for girls and women. Can these churches and FBOs be left out in their support for education? In many cases, they have been integrated into the public systems, where they share the commitment of the state to provide universal services to all, regardless of their identities.

With this in mind, the next section of the article focuses on the nature of partnerships that can exist at the local level. The way partnerships are perceived reflects their importance, both at the national and global level. To illustrate the point, I will refer to an early example of the Assemblies of God as well as to more recent examples of the FBOs mentioned above, AEAD and ANTBA.

\section{Local partnerships}

In order to be accountable and transparent in quality service delivery in girls' and women's education, local governments need to build solid partnerships with established national NGOs and churches which are already active in education to help them deliver quality education without religious and gender discrimination. Organisations such as AEAD and ANTBA have a good track record in terms of formal and non-formal education. The Education Orientation Law is explicit on the fact that civil societies and churches can create and run education systems. AEAD has, for instance, a close partnership with the local government in the areas of education and health. The local city government of Boulmiougou town, Ouagadougou, has worked in partnership with AEAD to provide formal and non-formal education for the communities. The mayor and her council provided lands to build schools and a medical centre. AEAD looks for funding and hires and trains the personnel, and the whole community is served. Nearly 50 per cent of the beneficiaries in formal education and 60 per cent of patients in the health sector are female. The churches and Christian FBOs are at the heart of the community's development, and AEAD is frequently invited by the local administration to give workshops with the elected council members to discuss strategies for development at community level.

\section{Partnership at the national level}

At the national level there is a political will to meet the SDGs, particularly the educational targets under SDG 4 (Quality Education). This is clear from the 
Education Orientation Law. It is stated in section 1, chapter 2, Article 3 that 'Education is a national priority' and Article 8 'the private education system is recognized'. Private education can be secular or confessional. Parents have the right to give religious, moral or traditional education to their children according to their own conviction and under the reservation of respecting the republican law.

These sections of the Education Orientation Law show the legal scope for churches and Christian FBOs to work within these legal frameworks. The same openness and collaboration found at local and regional authorities' level within the country are recognised at the national level. Different interviews conducted by the author with several authorities, such as the Director of Private Basic Education and Literacy and the officers at the directorate of Private Secondary Education Department, attest to the same willingness of the government to accompany Evangelical Churches and Christian FBOs in their common effort for girls' and women's education.

During my inquiry, I was able to meet the Director of Private Basic Education at the ministry level, François de Paul Sédégo, and the Ministry Delegate of Basic Education and Literacy, and had an audience and a letter from the Minister of Basic Education and Literacy. His Excellency the prime minister sent his Ministry Delegate of Education to act as chairman and read his speech for the official opening of the Speed School on 7 December 2007. That day the prime minister received the secretary-general of the Stromme Foundation and our three partner organisations in his office and appreciated, on behalf of the government, our contribution to girls' and women's education. He promised to do all he could to facilitate our contribution to the government's programme of education.

The Minister of Basic Education and Literacy, Odile Bonkoungou (2008), wrote a letter in the daily newspaper Les Editions Le Pays No 4080 to thank all the NGOs and associations that were working in education to help increase provision during 2007. She also congratulated the Cadre de Concertation pour l'Education de Base and the coalition of NGOs and associations for all their initiatives in favour of providing education to Burkina Faso children and promoting the development of the education system. Her letter indicated the good relations that exist between the government and the civil society, which includes the churches and Christian NGOs. This attests to the excellent partnerships between government, churches and FBOs for education in Burkina Faso. From the national level, I shall now proceed to analyse the situation from the international donors' perspectives.

\section{International partnerships}

To bring girls' and women's education in Burkina Faso to the desired level, more is required than the goodwill of churches and NGOs. Currently two-thirds of the female population in Burkina Faso are illiterate. The access to and the quality of education still needs substantial improvement. Even the policies of 
the government of Burkina Faso and its reformed education law need genuine and flexible support from the rich countries in order to make these policies a reality at community level.

Although great promises have been made by international donors, they need to be implemented, followed up and assessed.

\section{Myths about FBOs}

The allegation against FBOs that they might use development funds to proselytise needs to be explored, especially when dealing with communities that are deeply religious. Some FBOs offer a high quality of education without religious discrimination. They provide excellent educational services in compliance government policies and norms. They are seen as social partners by the government. For the Evangelical Churches, Christianity is a way of life that comes from a choice based on free will. Tolerance and freedom characterise its peaceful coexistence with other faiths in Burkina Faso. There is harmony between the faiths in Burkina Faso, and their leaders collaborate to maintain peace at the national level.

The issue of faith in development has been raised with the World Bank and the churches in Africa (Belshaw et al. 2001). If the World Bank and other related donor agencies acknowledge the pertinent involvement of the churches in education, then the Evangelical Churches and Christian NGOs in Burkina Faso, promoting an integral approach to education, should not be left to struggle on their own. How much greater will be the results towards achieving the goal of high-quality education when they work in partnership with government and international organisations?

There are some promising initiatives on the collaboration between development agencies and faith-based actors. The British Department for International Development, for example, has increased their funding for faith-based groups.

The efforts of the religious groups, such as the evangelicals, need to be matched by additional support through partnerships. This needs to be a true partnership that enables them to care for all, with religious sensitivity and with the respect of others. These FBOs will continue to support government educational plans, especially in rural areas where the demands are greater, if they are allowed to keep their religious distinctiveness - which is the source of their quality. Another aspect that should not be overlooked is that in addition to fulfilling the official programme, evangelical schools make a significant contribution to moral values, such as tolerance, gender, respect for public goods, love and care for one's neighbour, and good citizenship. These values are transmitted within these communities, and they cannot be negotiated with money. In the light of global security, Burkina Faso is a good example of a country where multifaith communities live in peace and all try to get involved in the educational development of the country alongside the government. The leaders at different levels work in harmony to resolve conflict in the neighbouring countries and want to preserve these cultural values through education. 
There must be a fundamental paradigm shift on the part of the government and international donors to enable the faith-based sector to achieve more. With more resources and training, churches and NGOs could open many schools in towns and villages, bringing education to all communities alongside the efforts of the government through innovative and best practices. UNICEF supports Muslim-based initiatives for girls' education. They could do the same with evangelical schools and networks. The author recalls over the last 20 years dialogues between the evangelical formal education bodies and the government's Department of Private Education asking them to reconsider their support for the church-related schools. At the time of writing, good initiatives are in prospect on the part of both the church and the government. When that happens, the support should be on an equal footing, allowing them to continue expanding their contribution to all children and speeding up the national plans.

\section{Conditionality in partnerships}

Partnerships between organisations or governments in the global North and the global South are often established by the northern partner organisations and agencies to fulfil a northern agenda. Critics such as Crossley and Watson (2003) have argued that it is time to consider local knowledge and context when referring to a productive partnership. Part of their argument questioned the relevance of a top-down approach. They argue that

the most powerful international agencies have come to dominate the development discourse with scant regard for local knowledge, local context and local research capacities. The way that international educational research and consultancy initiatives are often established and pursued can also be seen to help ensure Northern domination through new processes of neocolonial control.

(Crossley and Watson 2003, 115)

Some donor countries impose heavy conditions on their support for education. One problem is the practice of tying aid to the purchase of goods and services from the originating country. This undermines local economies. Moreover, very few international donors are willing to help countries to meet the running costs of education, especially the teachers' salary bill - even though this is the core of quality education! Rich countries and international financial institutions must work together to ensure that predictable resources are available over the long term to employ these indispensable professionals and provide classrooms, books, teachers and food. Moreover, the use of expensive consultants remains a problem. Many donors remain far more willing to supply developing countries with expensive consultants than help to pay teachers' salaries. Some figures indicate that the main donor countries provide more than 70 per cent of their aid to education in the form of technical assistance: study tours, seminars, capacity building, workshops and policy advice which may or may not be 
wanted. A good deal of this ends up generating lucrative contracts for foreign experts. These funds should rather go to the activities and programmes of actors, both faith-based and secular, who are rooted in the local communities.

\section{Conclusion}

Evangelical Churches, especially the Assemblies of God, and Christian FBOs work alongside the government to provide education that is non-gender discriminatory to local communities across the country. These religious actors' valuable initiatives in the promotion of female education merit the support of both the government and international donors. The collaboration with faithbased actors for education in Burkina Faso can contribute significantly to reaching the target spelled out under SDG 4. It should be based in equal partnership and respect the FBO's religious identity.

\section{References}

Belshaw, Deryke, Robert Calderisi, and Chris Sugden, eds. 2001. Faith in Development: Partnership Between the World Bank and the Churches of Africa. Oxford: Regnum; World Bank.

Bonkoungou, Odile. 2008. Letter printed in Les Editions Le Pays 4080.

Crossley, Michael, and Keith Watson. 2003. Comparative and International Research in Education: Globalization, Context and Difference. London: Routledge.

\section{List of interviews}

Sabine Compaoré, Head of Finances of the National Association of Bible Translation and Literacy (ANTBA). 8 February, 2006.

Innocent Kientega, Pastor and Director of the AOG technical school, 21 January 2005.

Sibiri Simporé, Pastor and former Secretary General of the Association of Evangelical Educators in Burkina Faso, Member of the National Executive Board of Assemblies of God Church until January 2010, 20 March 2006.

Flavien Tapsoaba, Pastor, Executive Member of the Federation of Evangelical Churches and Missions in Burkina Faso, Former President of the Apostolic Mission Church, Founder of the Raoul School Complex for basic education, 8 February 2006. 


\title{
17 Centre International d'Evangélisation/ Mission Intérieure Africaine's contribution to sustainable development in Burkina Faso through transformational development
}

\author{
Ini Dorcas Dah
}

\section{Definition of transformational development}

The term transformational development is taken from Wayne Bragg, the former director of the Hunger Center at Wheaton College, who states that the best term that fits a Christian view of development is transformation (Myers 2011, 153). Bryant L. Myers argues that transformation as a change is only possible when the lies that the poor have accepted about themselves, "[t]hat there is no better future, at least not in this world', are replaced by the truth that 'a better future' is possible $(2011,177)$. For Myers, '[h] ealing the marred identity of the poor is the beginning of transformation' $(2011,178)$. However, in the same way as the poor need to change their mindset, there is also a change in mindset required from the non-poor, who are often led by arrogant mindsets. For Myers, there is a need to educate the 'poor' to understand that they are also created in the image of God and have the potential to contribute to social well-being. The non-poor must also understand that they should not adopt an attitude of control over the poor. In other words, transformation starts from a change of mindset of people in their various social classes in their community. For Ernst M. Conradie (2016), talking about development is to talk about a process that leads to a transformation. Development can thus be seen as a process leading to a change gradually and not something that is hasty. To put it in Myers's words

Transformational development is a lifelong journey. It never ends. There is always more before us. Everyone is on this journey: the poor, the non-poor, and the staff of the development agency.

$(2011,3)$

In the Christian development programme, Jesus Christ is the focal point, because it is God who sustains life through Christ. Thus, their major aim is to bring the community to an understanding that sustainability involves a transformation of people's entire being: physically, mentally, socially and spiritually (Myers 2011, 193-200).

Transformational development, therefore, concerns the community and all the people in it regardless of their social class or their religion. For as Andrew F. 


\section{Ini Dorcas Dah}

Walls indicates, 'Christian conversion involves turning what is already there primal things, Islamic things, Buddhist things - toward Christ' (2017, 39). Christian development practitioners have to understand that a 'professional development can improve material, mental, and social life within the lifetime of the community members without changing the ultimate outcome of the bigger story' (Myers 2011, 175). In this view, it is only when people accept the saving grace of Christ that real transformational development is achieved. Although transformational development, as Myers uses it, ultimately aims at leading people to accept the saving grace of God, this does not mean that the Christian development practitioner automatically has to impose the salvation story on people. Within the concept of Christian transformational development, acceptance of the salvation story is not a human effort, but the work of the Holy Spirit who convinces people of sin, justice and judgement.

Development defined only through economic growth is missing the mark. It has to take into consideration other aspects such as social and environmental development. Sustainable development is therefore a socioeconomic and environmental development. It affects all aspects of societies: education and training, child protection and welfare, and practices that protect and sustain the environment (Lehtonen et al. 2002, 4). Thus, development is a change that affects the economic, social and environmental circumstances of people in a positive manner. It focuses on the wholeness of human beings in their sociocultural context by seeking to understand the community and it brings about changes that are necessary for positive transformation.

In the context of this article, I am using the word sustainability to indicate a support system that is not depleted or permanently consumed in order to lead to perpetual dependency. It is that which empowers the beneficiary to engage in a durable activity that will bring about a change in his/her conditions in a positive and lasting manner. Sustainability implies acting with the goal of leading people to achieve their autonomy rather than encouraging them to always rely on onetime gifts, which can leave them worse off than their initial state. It is leading people to implement their potential for their own benefit and not depend on outside help all their life. I therefore agree with the World Commission on Environment and Development's definition of sustainable development as '[d]evelopment that meets the needs of the present without compromising the ability of future generations to meet their own needs' (WCED, 1987).

In other words, sustainable development is about empowering people to develop their own means of survival within their socioeconomic, political and environmental contexts without causing threat to their future generations. And when the spiritual dimension is added to this, it becomes transformational development because it involves both body and soul. Centre International d'Evangélisation/Mission Intérieure Africaine (CIE/MIA) sees its work as holistic mission and development, that is, a Christian mission that considers the totality of the human being by taking care of both spiritual and physical dimensions of life. Prior to exploring the mission statement and some of these holistic approaches to mission by CIE/MIA, I will give a brief background of the founder of the church which might have informed the church's holistic approach to mission. 


\section{Religious background of Karambiri}

Centre International d'Evangélisation is an evangelical and international movement based in Ouagadougou, the capital of Burkina Faso. It was founded in 1977 by Mamadou Philippe Karambiri and his wife Marie Sophie Karambiri. The movement was officially registered on 9 December 1987. The church is a member of FEME: Fédération des Eglises et Missions Evangéliques du Burkina Faso (Federation of Evangelical Churches and Missions in Burkina Faso) and sees itself as an Evangelical Church even though most people in Burkina Faso still identify it as an African Independent Church (AIC). The public opinion about the church as Independent is probably due to the fact that it was founded by a Burkinabè and not a western mission-affiliated Evangelical Church.

Mamadou Karambiri was born into a Muslim family. He learned about Christianity when he was 10 years old. In 1973 he went to study economics in France and converted to the Christian faith in the Assemblies of God Church. He went back to Burkina Faso in 1977 and started his ministry while working with the Burkina Faso administration. He also worked with various organisations, as the Director for the Promotion of Exchanges at the National Office of Foreign Trade, the Commercial Director of Faso Fani and the General Director of Faso Yaar. In addition to that, he was the Vice-President of the Economic and Social Council, the Vice-President of the Chamber of Commerce and the Chairman of the Board of Naganagani Airlines. His involvement in these various organisations might have influenced his development consciousness in the church and the country in general.

CIE/MIA since its inception has not only opened many branches in the country but also in other African countries and abroad, including France and the United States of America. The main branch in Ouagadougou has 7,000 members and is the largest congregation of the church worldwide. This is a first attempt to document the contribution of CIE/MIA to sustainable development in Burkina Faso. I therefore used primary source material such as the 30th anniversary brochure, oral interviews with pastors and women leaders in some of the branches of the church, and online interviews with some of the media workers. I also used some of the electronic materials available on the CIE/MIA website and email correspondence with the Advancement Officer of the church. An overview of the mission statement of the church will help to understand the church's holistic approach to mission.

\section{Mission statement of CIE/MIA}

The mission of Centre-International d'Evangélisation/Mission Intérieure Africaine is to:

1 Proclaim the Lord Jesus Christ for the salvation and redemption of human beings,

2 Develop common evangelical actions that can bring members of different denominations together, 
3 Instruct members to live according to the Word of God and develop mutual love and spiritual unity,

4 Plant churches everywhere that this is necessary and train and ordain ministers to lead the congregations,

5 Contribute to the socioeconomic and cultural development of Burkina Faso through the building of training centres, develop social actions, agricultural and breeding activities.

(Centre International d'Evangélisation/Mission Intérieure Africaine/CIE-MIA, n.d.)

Thus, it is clear from the above mission statement that CIE/MIA is a church that is involved in evangelism, teaching, prayer, compassion and mission.

\section{Holistic mission and development/transformational development: proclaiming the salvation story through concrete actions}

CIE/MIA does holistic mission and development (transformational development) in Burkina Faso by undertaking both spiritual and social activities for the well-being of people. The main branch of CIE/MIA is called Le Tabernacle Béthel Israël/l'Eglise des Nations (Bethel Israel Tabernacle/All Nations' Church). Firmin Somé indicates that the main branch is called Tabernacle Béthel Israël, just to show that it is a place where the God of Israel is worshipped. This is the headquarters of the church and is located in Dassasgho in Ouagadougou. It was initially built to host 5,000 people and is used for both church services on Sundays and national/international conferences organised by the church. Mamadou Karambiri is the pastor of this branch. Karambiri has other ministers who are working in all the other branches. CIE/MIA following its mission statement has different departments in the church. As noted above, transformational development is about leading people to accept the saving grace of Christ through an holistic approach to mission. This can include developmental projects as well as the way the church treats the deprived in society. Thus, the first department in the church is the department of evangelism, which is in charge of organising outreach programmes on behalf of the church. This department had by 2007 opened 100 branches in Burkina Faso, 20 of the churches being in Ouagadougou.

One of the church's approaches to mission is investing in education. As indicated in the definition of sustainable development, education and training is one aspect affected by sustainable development. In 1992, the church also opened its first school. Currently the church has three primary schools and one nursery in Ouagadougou. It also has a primary school in Bobo-Dioulasso and one in Niger. According to Firmin Somé, even though the church only has a few schools, it has good results in terms of the children's social and spiritual education.

From 2000, CIE/MIA started sending missionaries out of Burkina Faso. As a result, by 2007, six churches were opened in Côte d'Ivoire, three churches in 
Benin, six churches in Guinea Conakry, two churches and a primary school in Niger; and outside of Africa two churches were opened in France and one in the United States of America. Melba Maggay points out that

Missionary movements, like the modern ones that rose from the evangelical awakenings of the eighteenth century onwards, likewise built schools and hospitals in their wake, doing various works of mercy in far-flung places alongside evangelisation. The impact of such work can be seen in the likes of Nelson Mandela, who in 1998 World Assembly of the World Council of Churches in Harare paid tribute to such efforts. As a boy he was too poor, he said. If not for mission schools, he could not have gone to school.

(2008, 46-52)

Maggay's statement shows that it is important to consider the vital need of people while doing Christian mission among them. Mandela's gratitude to the church in the quotation above is evidence that he would never have had the chance to receive formal education if not for the missionary schools in his country. The impact of Nelson Mandela in liberating the people of South Africa is widely known and one can only imagine what South Africa would be like today if Mandela had not had the chance to go to school and had not learned the Christian values that all humans are created equally in the image of God and deserve life regardless of their race.

According to Lilian Ayete-Nyampong (2015), among the 10 countries where people are the least educated, seven are in West Africa: Benin, Burkina Faso, Guinea Conakry, Mali, Niger, Senegal and Sierra Leone. CIE/MIA is therefore meeting the core needs of people in West Africa by not only caring for their souls through evangelism but also establishing schools where many children from poor families will have the chance to receive a formal education. In her study on AICs in post-apartheid South Africa, Barbara Bompani notes that '[e]ducation as emancipation was a recurrent theme and claim in the churches' (2010, 321). Even though CIE/MIA does not classify itself among AICs and their investment in education does not look big at the moment, one can still expect long-term positive impacts, because, as indicated above in the case of Mandela, Christian education has frequently led to the creation of competent leaders in Africa. Firmin Somé indicated (in a correspondence from Ouagadougou on 11 September 2018) that one of the teachings in the schools, in addition to Christian training, is educating children to be courteous in their society. The teaching of children to live in a courteous way is a good social value for pacific relationships among human beings, especially in countries with pluralistic religions and cultural practices.

According to Myers, '[o]ften the transformational development process begins with witness through good deeds' $(2011,201)$. The second department in the church is the department of hospitals and maternity. Members of this department are both women and men engaged in reaching out to people in hospitals to share the Gospel with them and assist them with financial and material 
support, particularly by paying for the treatment bills of some sick people. This department also sensitises people to HIV/AIDS and provides free tests for those who wish to take them. Although this may sound more like social relief and welfare, the work of this department not only touches the spiritual life of the sick people through the Gospel, but it also transforms their entire being through social and environmental concerns which are part and parcel of development. One cannot talk about sustainability when people in the community are weakened by sicknesses in an unsound environment; as we know, good hygiene and sanitation contribute to the eradication of many diseases and therefore improve people's overall well-being.

From 2010, CIE/MIA renovated its system of help for vulnerable persons such as widows, orphans and street children. The church not only visits them, but the month of December is set apart as the month of compassion. The morning of 24 December is the communion day with vulnerable people. The government, media, the public and even the church all too often convey the message that people who are incarcerated are the worst people in society, and these people often end up adopting an attitude of blaming themselves (Chapman 2008, 53-61). Reminding people of their wrongdoing all the time and making them feel guilty about their life is tantamount to rejecting these people in our societies. Instead, the members of the prison department in CIE/MIA do not go to prisons to remind people of their evil doings of the past but to reach out to them with the Good News of the Gospel. They also clean the prison cells, disinfect the place to improve hygiene and provide medical care for the prisoners. Living in a sound and clean environment is important for the health of the prisoners and also shows the importance that the church gives to creation as a whole and thus brings hope; for, as indicated in Principle 1 of the Rio Declaration, 'Human beings are the centre of concerns for development. They are entitled to a healthy and productive life in harmony with nature' (United Nations Conference on Environment and Development 1992, 1).

Furthermore, the church does not go to the prison cells just to share the Gospel but leave the people wandering on their own when they are freed. Rather, the prison department in CIE/MIA has contributed to changing former prisoners' lives by making sure that people are nurtured after prison to embrace life in a positive manner. Therefore, many former prisoners are now involved in full-time pastoral ministry. This is an indication of a positive transformation in those prisoners' lives to a point that they are also engaged in changing other people's lives not only as ministers of the Gospel, but in doing honest work in their societies. This department is also involved in rescuing street children and offering them training, such as carpentry, mechanics, and so on. Once again, sustainable development affects all aspects of societies: education and training, eliminating child labour, and promoting recycling in order to protect the environment (Lehtonen et al. 2002, 4).

Thus, preaching the Gospel in prisons is important but the most significant action here is the initiative to prevent reoffending, because sustainable development is not only about dealing with the current circumstances of people in their communities, but it is also helping them face their future in a responsible 
manner. As already noted above, CIE/MIA sees its work as a holistic approach to mission. As Myers argues

We must know who we are and the purpose for which we were created. Therefore, restoring identity and recovering vocation must be the focus of biblical understanding of human transformation.

The prison department does not overlook the socio-religious past of the prisoners in dealing with them in their present condition in prison. That is why this ministry is organised in such a way that it can find suitable activities for freed prisoners to do after they are released so that they do not fall back into their past habits and even become worse than they were before going to prison.

The plan of finding jobs for street children is also commendable because one cannot talk of sustainable development in a country if children in that country do not have access to basic education and spend their time in the streets where they learn all kinds of social vices and participate in antisocial practices that disturb the peace and security in society. In other words, the transforming message of the Gospel is preached through practical deeds and helping the people to be aware of their vocation in their communities so that they don't rely on one-time gifts handed over to them, but grow out of dependency to contribute to the building of their society (Myers 2011, 193-202). Mamadou Karambiri himself is involved in educating people to maintain peace in Burkina Faso and other parts of Africa, thus making the church an instrument and promoter of peace in Africa (l'Observateur Paalga No. 9530, 2018, 18).

Another department in the church is the children and youth ministry. The children's group is made up of all those between 5 and 15 years old in the church. This ministry is carried out by adults in the church who have volunteered to educate all children to learn from the Bible and also activities like art, songs, dance and drama and so on. The youth department involves young people above the age of 15 . These young people meet to learn how they can bring about a positive change in the world. They also have a programme which consists of visiting elderly people who live in isolation in order to support them in their lives. There is also the student department, which consists of reaching out to students in secondary schools and universities. Extra classes are organised in order to help students improve their academic abilities. In other words, the students in CIE/MIA are involved in seeking excellence in the country, which is a positive engagement from their department.

Another important aspect of development is the role of women. Principle 20 of the Rio Declaration of 1992 is that '[w] omen have a vital role in environmental management and development. Their full participation is therefore essential to achieve sustainable development.' This implies that women have fundamental contributions to make towards the sustainable development of their countries. This can be achieved through concrete actions taken by women in the communities to bring about changes that have positive and lasting impacts. Thus, 
one of the major departments that is impacting the life of the church and people's lives in the entire country is the women's movement. It is reported in the brochure of the 30th anniversary of CIE/MIA that Marie Sophie Karambiri, co-founder of the church, started the movement as soon as she and her husband founded the church in 1977. She named the movement 'Group Esther'. The 30th anniversary brochure introduces the group in this way: 'Le groupe Esther: ce groupe, initiateur de la vie de prière du Centre International d'Evangélisation/Mission Intérieure Africaine continue à le soutenir par ses prières hebdomadaires' (Group Esther: this group, initiator of the prayer life of CIE/MIA still continues to sustain the church through its weekly prayers). This movement, from its inception, dedicated its time to praying for the church under the leadership of its founder until her death. In 2010, Mamadou Karambiri remarried Orthance Palm and the group took the name Femmes de Destiné (Women of Destiny).

The women's ministry works particularly for the independence of women through the establishment of the compound of trades such as soap making, weaving, tailoring, hairdressing, restaurants, and the commercialisation of peanut butter and so on. The women's products are sold in the 'Boutique de la Femme de Destiné'. All these activities have contributed to creating jobs for women who can now meet their personal needs. There is also the widows' section which is called 'the Ruth'. This section allows women to borrow money from their own account to start their own business.

For instance, in the Birifor area, there is a Group Esther in Batie (South West of Burkina Faso) which started in 1998 with Mr Abdoul Karim Ouédraogo and his wife. According to Jacqueline Somdo/Abème, the secretary of the Group Esther, they meet every Saturday to intercede for the church, their families and the whole world.

With the direction that the group took from 2010, the women added other activities to their prayer programmes. They also have social ministries which consist of visiting people in the community, in the hospital and in the prison. For instance, one activity of the leaders of les Femmes de Destiné is to help Birifor women who were brewing local beer and converted to Christianity to find alternative income-generating activities. Femmes de Destiné Batié is trying to assist women to do activities that will not jeopardise their Christian witness. The Birifor local beer is very lucrative for Birifor women, but it is also the source of various social problems among these communities.

Philip Jenkins argues that

Membership in a new Pentecostal church means a significant improvement in the lives of poor women, since this is where they are likely to meet men who do not squander family resources on drinking, gambling, prostitutes, and even second households.

$(2011,97)$

In Birifor society, some men are addicted to drinking local beer and find it very difficult to stop drinking even when they convert to Christianity. In other 
words, Femmes de Destiné does not ask people to stop their lucrative activities that people may find questionable for these women's Christian identity and leave them to manage on their own without any support. The group is fully engaged in following up with its members and provides financial support for those who desire to undertake a different activity but do not have the means to do so. In talking about the Women of Destiny's activities among the Birifor, I explain that the importance here is twofold; that is, helping women who converted to the Christian faith find an income-generating activity that is suitable to their Christian faith and bringing about social change in families because men who are addicted to alcohol frequently spend all their time outside of their households squandering family resources on alcohol without paying attention to the needs of their wives and children (Dah 2017, 168). The idea of social transformation is very important in the ministry of the Women of Destiny because the social aspect of change is one of the pillars of human activities that sustainable development has to affect.

The church also has the department of media and publications and a television station named Impact TV. Impact TV was inaugurated on 7 March 2008 and Marie Sophie Karambiri, co-founder of the church, passed away on 12 March the same year. The TV programmes started in June 2010. Impact TV was the first private television station in Burkina Faso to be on satellite. Today it is on two satellite stations, social media, and so on. Impact TV works in partnership with churches, associations, NGOs, the civil society and the state in order to contribute to the spiritual, social, educational, political and economic development of the country. Thus, it has the lowest advertisement rates with the aim of contributing to the socioeconomic development of the country.

The impact of CIE/MIA through Impact TV is not limited to its programmes. It also creates jobs for young people in Burkina Faso and thus reduces unemployment in the country, by contributing to solving one of the major concerns of Goal 14 in the 2030 Agenda for Sustainable Development (United Nations 2015). In his talk entitled 'Challenging Cultures, Changing Nations for a Common Good', at the Institute for Christian Impact Seminar on 'Mission for a Bright Africa', in Ghana on 2 July 2018, David Zac Niringiye indicated that the church does not need to pray for young people to find jobs, but must rather create jobs and employ the young people. For, even though Darrell L. Whiteman in his discussion about economic development argues that, "[e]conomic development does not automatically lead to human development', he points out 'the creation of jobs, and the reduction of dependency' as one of the new alternative values for development (1990, 121-122).

\section{Conclusion}

Centre International d'Evangélisation is an Evangelical Church founded by a native Burkinabè and his late wife, a fact which has contributed to the local community seeing it as an AIC. However, the church is a full member of FEME. Its mission statement focuses on evangelism, teaching, prayer, compassion and 


\section{Ini Dorcas Dah}

mission. The church uses a holistic approach to mission to touch both the hearts and lives of people and is spreading the Gospel in Burkina Faso and other parts of the world through its various ministry departments.

Using the holistic approach to mission to impact both communities and individuals is a way of participating in the sustainable development of the country because the church does not only undertake actions that meet the temporary needs of people, but is developing mechanisms that can help them face both their current and future circumstances in order to not return to their negative pasts. In other words, it is helping people who are in need in such a way that they are not always depending on temporary aid and being left worse off when that aid runs out. It is empowering people to meaningfully face their life circumstances so that they can improve their lives, circumstances and societies.

Thus, CIE/MIA is contributing to sustainable development by not only proclaiming the Good News of the Kingdom through the preaching of the word of God, but also undertaking concrete actions through teaching, healing and empowering people to help them improve their lives, and for those who have been excluded for various reasons, to be readmitted to their communities where they in turn can help and impact others for a positive change in their society. For ' $[t]$ he activity of God redeeming and restoring creation includes poverty eradication along with the other elements of the Gospel' (Myers 2019, 12).

\section{References}

Ayete-Nyampong, Lilian. 2015. 'Social and Economic Empowerment of Women in Africa.' Presentation at the 2015 Tumekutana Gathering, Abokobi, Ghana, 22 September. 2015. Unpublished typescript.

Bompani, Barbara. 2010. 'Religion and Development from Below: Independent Christianity in South Africa.' Journal of Religion in Africa 40 (3): 307-30.

Centre International d'Evangélisation/Mission Intérieure Africaine/CIE-MIA. n.d. '30 ans.' Unnumbered typescript.

Chapman, Haami. 2008. 'To Respond to Human Need by Loving Service (ii).' In Mission in the 21 st Century. Exploring the Five Marks of Global Mission, edited by Andrew Walls and Cathy Ross, 53-61. London: Darton, Longman and Todd Ltd.

Conradie, Ernst M. 2016. 'Why Cannot the Term Development just Be Dropped Altogether? Some Reflections on the Concept of Maturation as Alternative to Development Discourse.' HTS Teologiese Studies/Theological Studies 72 (4). http://dx.doi. org/10.4102/hts.v72i4.341.

Dah, Ini Dorcas. 2017. Women Do More than Men. Birifor Women as Change Agents in the Mission and Expansion of the Church in West Africa (Burkina Faso, Côte d'Ivoire and Ghana). Akropong-Akuapem, Ghana: Regnum Africa.

Jenkins, Philip. 2011. The Next Christendom. The Coming of Global Christianity, 3rd ed. Oxford, New York: Oxford University Press.

Lehtonen, Markku, C. De Pretorius, S. Duchassaing, and D. Michel. 2002. Le Développement Durable: Signification et Enjeux/Sustainable Development: Meaning and Challenges. Groupe Caisse des Depots et le Cercle des Economistes. 
Maggay, Melba. 2008. 'To Respond to Human Need by Loving Service (i).' In Mission in the 21st Century, Exploring the Five Marks of Global Mission, edited by Andrew Walls and Cathy Ross, 46-52. London: Darton, Longman and Todd Ltd.

Myers, Bryant L. 2011. Walking with the Poor: Principles and Practices of Transformational Development. New York: Orbis Books.

Myers, Bryant L. 2019. 'Mission and Development: Two New Opportunities and a Continuing Challenge.' Mission Studies, Journal of International Association for Mission Studies 36: 11-37.

United Nations. 2015. Transforming Our World: The 2030 Agenda for Sustainable Development $\mathrm{A} / \mathrm{RES} / 70 / 1$. United Nations.

United Nations Conference on Environment and Development. 1992. 'The Rio Declaration on Environment and Development.' United Nations.

Walls, Andrew F. 2017. Crossing Cultural Frontiers. Studies in the History of World Christianity, edited by Mark R. Gornik. Maryknoll, New York: Orbis Books.

Whiteman, Darrell L. 1990. 'Bible Translation and Social and Cultural Development.' In Bible Translation and the Spread of the Church. The Last 200 Years, edited by Philip C. Stine, 120-141. Leiden, New York: E. J. Brill.

\section{List of interviews}

Jacqueline Somdo/Abème, Interview, 11 December 2013.

Ouédraogo and Jacqueline Somdo/Abème, Interview, 11 December 2013.

Tindano, Perside, Messenger Interview from Ouagadougou, 29 January 2018. 
$\Longrightarrow$ Taylor \& Francis Taylor \& Francis Group http://taylorandfrancis.com 
Part V

Zimbabwean perspectives 
$\Longrightarrow$ Taylor \& Francis Taylor \& Francis Group http://taylorandfrancis.com 


\title{
18 Investing in the future generation New Pentecostal Charismatic Churches in Harare, Zimbabwe
}

\author{
Simbarashe Gukurume
}

\section{Introduction}

God sent me to deal with poverty. I was called to deliver his people from poverty and suffering. Gone are the days when 'men of God' used to tell people that blessed are the poor. God does not want his children to be impoverished - he wants them to prosper and be wealthy. That is what we teach and do here. In our youth ministry - we target young people. We want to empower them and change their mindset. We teach them business, entrepreneurship - to be self-reliant and we send them to school - to university. We want them to have a bright future. So we are investing in the future generation - that is sustainable development.

(Pastor Innocent 5 October 2016)

The quotation with which I open this chapter is from Pastor Innocent ${ }^{1}-\mathrm{a}$ youthful and charismatic leader of a popular Pentecostal Charismatic Church (PCC) in Zimbabwe. Pastor Innocent's quote encapsulates the ways through which new PCCs engage practically and discursively with sustainable development. Indeed, the quote highlights the ways through which the church - more specifically a new PCC becomes a space where development is reimagined in very specific spiritual ways. For Pastor Innocent, and indeed many pastors and prophets of new PCCs in Zimbabwe, development is not just the prerogative of the state. Instead, the church has a very important role to play in the development of its congregants and the nation at large. At Pastor Innocent's church, young people are urged to engage in business - to participate in politics and become 'responsible' leaders in the here and now and in the future. For those already in, the pastor encourages them to shift to a higher level.

You should not be in a comfort zone - think big and expand your territory and God will bless the works of your hands. If you have a kiosk, do not think that God wants you to remain there, if you have one shop - start preparing for the second one and counting because God wants you to be prosperous,

shouted Pastor Innocent during a church service. During the church services, the pastor consistently emphasised the importance of entrepreneurship and civic engagement for personal and community development. 


\section{Simbarashe Gukurume}

This chapter is divided into five sections. In what follows, I discuss the methodology that informed this study. This is followed by a discussion of the Pentecostal revolution in Zimbabwe and Africa more broadly. In this section I show how new PCCs moved from the periphery to the centre of the religious terrain and how this recent shift has shaped the country's religious and development landscape. In the next section I discuss and engage with broader scholarly debates on the nexus between Pentecostalism and sustainable development. From there I discuss the Pentecostal discourse of prosperity gospel and how this mediates development. New PCCs' emphasis on prosperity gospel is one of the key contributions that new PCCs are making to individual and community socioeconomic development. In the section that follows, I zero down on the specific activities that new PCCs engage in which directly and positively reconfigure the socioeconomic subjectivities of their members. I particularly discuss the entrepreneurship workshops and trainings offered to young people and how these reorient young people's aspirations and perspectives on and about the future. The last section discusses the role of new PCCs in the educational attainment of young people. It looks at the financial assistance offered to poor and less-privileged students by new PCCs and how this is viewed as an investment in the future generation. For new PCCs all these activities are viewed as the panacea to the sustainable development conundrum confronting postcolonial Zimbabwe. After this section I then conclude, and argue that by investing in young people - the future generation, new PCCs are significantly contributing to sustainable development. However, I caution that in spite of all these activities, some new PCCs' teachings, rituals and belief system can hinder the attainment of sustainable development.

\section{Doing ethnography in Zimbabwean PCCs: methodology}

This study is embedded in an interpretive qualitative methodological orientation. In the collection of primary data, I triangulated participant observation, semi-structured interviews and key informant interviews as well as informal conversations with congregants. My fieldwork was led by two research questions: how and in what ways do new PCCs reconfigure young people's futures? And how do new PCCs in Harare promote and contribute to sustainable development? To augment the data gained in the field, I also made use of secondary data collected from a number of different of sources such as newspaper articles, church publications and reports as well as sermons. Semi-structured interviews were conducted during a longitudinal ethnographic fieldwork that started from January 2015 to date. For this chapter, I used information drawn from 30 participants who were purposefully selected and interviewed. Participants were selected based on their in-depth knowledge about the subjects. Thus, all participants were information-rich cases who were directly involved. Participant observation was in the form of regular attendance of church services and meetings in and around Harare. Attending church services and related meetings enabled me to observe and interact with participants in their regular settings. 
This also enabled me to forge trusting relationships and build rapport with my interlocutors in PCCs. I attended more than 40 church services and more than 10 business workshops and conferences in Harare. The data used for this chapter is drawn from three new PCCs based in Harare. The majority of my interviews were conducted in English, though some of my participants mixed English and Shona. I personally translated all the Shona statements and quotes into English.

\section{The Pentecostal revolution in Africa}

Over the past 20 years, there has been a remarkable explosion of Pentecostalism in Africa and in Zimbabwe more particularly. Many scholars have noted that Pentecostalism is the fastest growing religious movement in the world (Anderson 2004, 1; Burgess and van der Maas 2002; Chitando and Biri 2016; Haynes 2015; Hollenweger 1997; Martin 1990; Van Wyk 2014). For instance, mission specialists like David Barrett noted that the Pentecostal movement is growing rapidly with almost 52,000 converting per day and 19 million converting each year worldwide, with the majority in Africa and Latin America (Gukurume 2018b). At that rate of growth, estimates reveal that by 2025, there could be about one billion Pentecostals globally (Barrett 2001; McClung 2006, 35). Indeed, according to the World Christian Database the majority of the world's Christians are Pentecostals. Similarly, scholars like Martin (2002) viewed Pentecostalism as the biggest shift in the global religious landscape. Nowhere is this spread and growth more rapid than in Africa where the majority of Pentecostal Christians now reside (Gifford 2004; Gukurume 2018b).

For some scholars, Pentecostalism is a global religious movement (Cox 1995; Robbins 2004; Ukah 2003). Indeed, scholars like Cox $(1995,102)$ note that Pentecostalism is a highly mobile religious movement. In their own self-making, new PCCs in Zimbabwe imagine themselves as transnational and international. Similarly, some scholars note that the transnational spread and appeal of Pentecostalism represent a marked feature of cultural globalisation (Gifford 2004; Jorgensen 2005; Robbins 2004). Similarly, new Pentecostal Churches in Zimbabwe have been framed as a 'fourth wave' form of Pentecostalism (Gukurume 2018b).

New PCCs that have radically altered the religious terrain in Africa attract thousands of congregants at their services - often packing giant sports stadiums (Gukurume 2018b; Van Wyk 2014). Scholars argue that Pentecostalism is attracting many people in Africa because its teachings resonate strongly with African ontologies, sensibilities and realities (Gukurume 2018b; Meyer 1998). Indeed, a marked feature of these new PCCs is their twin theology of prosperity gospel and spiritual warfare against the devil and his demons (Anderson 2004; Biri 2012; Coleman 2002; Gifford 2004; Hunt 2002; van Wyk 2014). In fact, the defining features of new Pentecostal Churches are prosperity gospel and spiritual warfare against the demon of poverty. These twin discourses are a common feature of the global Pentecostal movement (Coleman 2002; Robbins 2004; van Wyk 2014). Apart from a heavy emphasis on prosperity gospel, they also engage in ascetic forms of worship, possession of the gifts of the Holy Spirit such as 
glossolalia (speaking in tongues), prophecy, exorcism (deliverance) and miraculous spiritual healing of chronic diseases like HIV and cancers. Interestingly, some of the new PCCs have also prioritised social ministry and political action (Ganiel 2009; Miller 2009; Miller and Yamamori 2007). These scholars argue that new forms of Pentecostalism have placed social engagement at the centre of their activities. Their social engagement activities are normally in the areas of education, healthcare and economic development. These new PCCs that promote civic engagement and socioeconomic development have been framed as 'Progressive Pentecostals' (Burgess 2009; Ganiel 2009; Miller and Yamamori 2007). Most of these progressive PCCs have established development departments that deal specifically with development related projects in the community.

Indeed, for many of the new PCCs, the endemic poverty bedevilling many African countries is a brainchild of the works of demons - it is a consequence of the demonic. This poverty and its attendant anxieties are more pronounced among the youth who constitute the demographic majority in Africa. Van de Kamp $(2010,152)$ noted that the phenomenal growth of Pentecostalism relates to the ways in which this movement critique and destroys the current development models. In turn, they introduce new development models that are spiritually anchored and embedded in the community. For many new PCCs, old development models marginalise youth.

Indeed, due to the chronicity of the economic crisis in the postcolony, some scholars have argued that young people are in a state of immobility - what Singerman (2007) and Honwana (2014) referred to as 'waithood' - a scenario where young people's transition from childhood to adulthood is suspended. New PCC view this condition of 'waithood' and the poverty and suffering which characterise it as demonic. While Honwana noted that this youth crisis is global, it is more pronounced in Africa (Gukurume 2018a).

Many new PCCs view it as their role to deliver their congregants and indeed their countries from poverty through spiritual technologies such as prayer and exorcism. For Pentecostals the world is imagined and constructed as a space that should be transformed through action - both individual and collective. Many scholars argue that the phenomenal success of the Pentecostal movement in poverty-stricken spaces is due to this theology and its promise for material prosperity with Godly blessings amid widespread poverty (Comaroff and Comaroff 2000; Lewison 2011; Van Wyk 2014). In church services, many congregants give testimonies that reveal how they began to accumulate material blessings from God when they became 'born again'. In Pentecostal parlance, being born again becomes a pre-requisite for prosperity. New PCCs underscore the importance of transforming the individual in every aspect of life. This transformation is part of the metaphor of what scholars refer to as a 'complete break with the past' - a rapture that entails converts becoming reborn through cutting ties with their past. For many scholars it is this transformation or creation of a 'new being' which in turn sow the seeds of development (Maxwell 2000; Freeman 2012). This discourse of transformation emphasises the importance of a total 
conversion of the 'entire being', spiritually and socioeconomically. Maxwell (1998) referred to this process as the total 'remaking of the individual'. Freeman (2015) argued that what should be underscored is how a reconfigured 'Pentecostal subjectivity' closely mirrors a 'neoliberal subjectivity' which is not only a pre-requisite, but also a requirement for succeeding in a neoliberal capitalist economy (see Lewison 2011; Maxwell 2005; Comaroff and Comaroff 2000). Similarly, new PCCs also inculcate a culture epitomised by sobriety, industriousness and self-discipline, all of which are crucial requisites for development. So, the question that can be asked is; what is the possible role of these Pentecostal rituals in development discourse and practice?

\section{Pentecostalism and sustainable development}

For new PCCs sustainable development is at the centre of their theology, teachings and activities. Indeed, for many new PCCs there is a duality between religion and development (Freeman 2015, 2). While mainline churches have a long history of engagement in development activities, new PCCs are recent entrants in the development landscape. Following their mainline counterparts, new PCCs are also establishing Faith Based Organisations (FBOs) and NGOs which drive their development endeavours. For scholars like Freeman (2015) it is these Pentecostal organisations which have radically transformed the development terrain in many African countries.

Given the rapid growth of Pentecostalism in Zimbabwe and beyond and its resiliency in public spaces, many scholars have begun to theorise and foreground the potential role of these PCCs in the development process of many countries (Freeman 2012, 2015; Togarasei 2012; Musoni 2013). However, of note is that research on the possible impact of religion on socioeconomic transformation is not new. This nexus between religiosity and development has been subjected to empirical examination since the Weberian times (Weber 1930). This classical scholarship largely focused on Protestant Churches and how their teachings, values and principles fostered the growth and spread of capitalism. Therefore, what is new is the role of emergent forms of Pentecostalism in development. Focusing on Zimbabwe and Botswana, Togarasei (2012), argues that Pentecostalism could be the panacea to the sustainable development conundrum facing these countries through their poverty alleviation programmes. Indeed, there is a growing scholarship that recognises and acknowledges the centrality of religious actors in development (Berger 2010; Tyndale 2006; Haynes 2007). However, while this literature is insightful, it does not focus specifically on youth programmes that help them navigate existential precarities. As such, this chapter builds on this body of work, while making an original contribution by focusing on PCC initiatives that seek to empower the youth. Berger (2010) asserts that there is a close affinity between Pentecostalism and modern economic development. For instance, given the crucial role played by remittances in the socioeconomic development of sending countries, some scholars have begun to explore the resources generated through PCC networks in driving and sustaining 


\section{Simbarashe Gukurume}

population mobility (see Burgess 2009, 255; Pasura 2012, 34; Adogame 2004; Van Dijk 1997, 148).

Ter Haar and Ellis $(2006,352)$ argued that religion should be given attention in development thinking and practice. Other scholars have also considered religion as a catalyst for development (Berger 2010; Deneulin 2009; Deneulin and Rakodi 2011). Indeed, the importance of religion in development has been under discussion in a number of international development organisations such as the Bretton Wood Institutions (Marshall and Keough 2004; Tyndale 2001).

\section{Prosperity gospel and development}

One of the prominent features of new Pentecostal Churches is its twin theology of spiritual warfare and the health and wealth gospel popularly known in Pentecostal parlance as prosperity gospel (Gifford 2004; Van Wyk 2014; Haynes 2012; Gukurume 2017). This prosperity theology inculcates a sense of optimism and belief that every born again Christian can make it in life. In fact, in PCC sermons during Sunday and other services, congregants are constantly reminded that they are the children of the 'most-high' God - a God who owns it all, including gold and silver. 'If you believe that you are a child of God then it is your entitlement to be rich materially, spiritually and socially, in every part of your life - you just have to claim what belongs to you and reclaim what the devil had stolen from you through positive confession'; one prominent Pentecostal Prophet retorted in a well-attended Sunday service for the youth in Harare.

This prosperity however does not always come cheap for the PCC congregants. To stand a chance to be prosperous and wealthy, members are ordered to pay huge amounts of money and gifts as sacrifices to the church - a practice known as seeding in Pentecostal parlance. ${ }^{2}$ These huge financial sacrifices are framed as pre-requisites to material prosperity, without which one's chance of upward mobility becomes limited. For instance, during my fieldwork, one popular Pentecostal Church in Harare, UFIC posted a video on its social media platforms which attracted a lot of attention. The video urged people to make financial sacrifices for them to be successful in the New Year; the shortened transcript of the video is below:

It may be interesting to note that number seven is a prophetic number, a number of perfection which makes the year 2017 a year of your dreams, hopes, aspirations and all your visions, if only you are willing to start it perfectly ... we are to sacrifice, we are to sow seeds and we are to cut covenants with God. People who want to be blessed in 2017 should sow seeds of up to $\$ 77, \$ 770, \$ 7,700, \$ 77,000$ or whichever way the spirit of God leads you. Sow your seeds in the multiples of $\$ 77$.

During interviews and conversations, my interlocutors told me that there are very specific categories in the churches based on how much they sacrificed to the church. For instance, in UFIC, congregants are classified under the gold, 
silver and bronze classes based on the money they give to the church (Biri 2012, 8; Taru and Settler 2015, 130; Gukurume 2018b). Indeed, some elite congregants pay up to millions of dollars to the church in offerings, tithes and seeding (Laiton 2017). ${ }^{3}$ The gold partners enjoy special benefits, preferential treatment and often have easier access to the man of God. They are often given special chairs close to the auditorium during church services and often have one-onone meetings and interactions with the man of God. Thus, during my fieldwork, I observed that financial contributions were particularly overemphasised, and many congregants tried to sacrifice their full monthly salaries. Some congregants sacrificed all their money to the extent of starving themselves so as to be closer to the prophet. Consequently, what often happens in new Pentecostal Churches is that the 'men of God' are becoming progressively richer, while their congregants' poverty and suffering worsen due to the huge financial sacrifices they make to the church.

As such, the prosperity gospel propagated in new PCCs is not without critics. For instance, most of the critics accuse them of swindling desperate congregants of their hard-earned money. In fact, some scholars note that prosperity gospel tends to justify wealth accumulation by individuals and spiritualise poverty as a consequence of the demonic. This diverts people's attention from the root causes of poverty and inequality (Marshall 1993, 230; Gifford 2004, 382; Gukurume 2018b). Similarly, through its emphasis on financial sacrifice, some scholars argue that PCCs are profit making organisations (Ukah 2007, 643; Van Wyk 2014). While seeding is predominantly financial, it can also be in other forms such as voluntary service to the church, provision of gift to the prophet in the form of houses, cars or clothes and groceries. Seeding was framed as the fuel that propels one to upward mobility and success. The more money one sacrificed to the church the higher the chances of making financial breakthrough and progress, at least in theory. For Ukah (2007) while Pentecostal Churches present themselves in public as philanthropic, they are in fact self-serving entities which are not necessarily interested in the common good.

While people consistently made huge financial sacrifices, not all of them succeed and become prosperous in achieving their aspirations and dreams. Many do remain in abject poverty. In fact, many of them sink deeper and deeper with time. This non-materialisation of wealth and prosperity is often blamed back to the people - that they lack adequate faith or that they are not sacrificing enough money for their wealth to materialise in the here and now. This finding resonates strongly with arguments made by many scholars that some congregants hardly prosper in their social and economic lives, but instead their lives become uncertain and impoverished (van de Kamp 2010, 153; Van Wyk 2014). However, this delayed or non-materialisation of prosperity compels many new PCCs to reshape their prosperity teaching in terms of what they promise congregants as well as the time and temporalities of the promised material success (Haynes 2012; Van Wyk 2014). For some of my interlocutors, the elusiveness of what the church promises was a source of frustration and anxiety which often led some of them to move from one church to another. Indeed, other 


\section{Simbarashe Gukurume}

congregants have taken the prophets to court demanding their money back after years of sacrificing to the church without any improvement in their fortunes (Chitemba 2017). ${ }^{4}$

\section{Entrepreneurship workshops in new PCCs}

Some new Pentecostal Churches with which this study focused on have ventured into business. Indeed, some new Pentecostal Churches have not only formed huge business ventures but have become business ventures themselves. For instance, PCCs like the Prophetic Healing and Deliverance (PHD) ministries, Good News Church have ventured into real estate in Harare. In fact, in February 2018, PHD opened a huge multi-million-dollar Yadah marble factory which employs about 3,000 employees (Sachiti 2018). ${ }^{5}$ Much of the employees are drawn from qualified church members.

During my fieldwork, several churches organised business workshops and entrepreneurship training. While these workshops and summits help to inculcate an entrepreneurial ethic among congregants, it also comes with huge financial benefits to the church. For instance, the United Family International Church (UFIC) held several business conferences with the most popular being the 'Billionaires Mindset Summit'. ${ }^{6}$ To attend this summit people had to pay a minimum of US $\$ 150$ per person. This summit has become an annual glamorous event. It is held at the affluent Rainbow Towers Hotel and attracts thousands of people including several of my youthful interlocutors who sacrifice their hardearned money to attend the event. At this summit, the church invited renowned business tycoons to speak to the thousands of attendees. For instance, during my fieldwork the church invited an Angolan millionaire and Pastor $\mathrm{Dr}$ Teddy De Almeida and a renowned local businessman and Pastor Dr Shingi Munyeza. These business people shared their success stories and how they made it to the top. Most of their stories depicted a rags-to-riches narrative which is deliberately performed and articulated to motivate and encourage the people that with God nothing is impossible. In one of the services I attended, the prophet shouted loudly to a cheering crowd:

the devil want you think that you cannot make it, you cannot be successful, that's a lie - the devil is a liar, God blesses the works of your hands start something and it shall multiply and prosper. I prophesy into your life that you will be a success, you will prosper - I declare success in your business, more profits and more breakthroughs.

For scholars like Freeman (2015) such declarations and entrepreneurship training often lead the congregants towards the direction of what many scholars call development. The importance of workshops like the Billionaires Mindset summit is salient on how they reconfigure people's mindset and reorient them (Barbalet 2008, 75) towards a different kind of future marked by socio-economic prosperity. Thus, this reconfiguration of the mindset becomes part of the innate 
deliverance which prepares congregants for success in the near and distant future. I contend that organising business workshops and inculcating entrepreneurial skills is part of the repertoires of new PCCs strategies to provide spiritual and material deliverance to their members. This deliverance has a very powerful psychological effect on the lives of the delivered congregants. As emphasised by one of the prophets in a Sunday service:

People can talk of demons being cast out, people being healed and all, but the most important form of deliverance from poverty and underdevelopment in Africa is the deliverance of the mindset - we need to transform your mindset and that is what I am going to do today. I want to teach you and change the way you perceive the world - your mindset. With the right mindset, you can develop not only yourself but also your community, your country and your continent - that is why I came up with the 'Billionaires Mindset' summit so that people can have that business mind.

I contend that this reconfiguration of the mindset tends to contribute positively to socioeconomic well-being of the people in question. Indeed, during these business workshops and training sessions, people are actively encouraged to start their own businesses no matter how small. For these church leaders, by establishing companies and other businesses, God will make them prosper and fulfil their aspirations and dreams epitomised by luxury - huge mansions, latest fashion, posh cars and happiness (van de Kamp 2010, 153; van Wyk 2015; Gukurume 2018b). One of the popular Pentecostal pastors, Prophet James based in Harare, told me in an interview that:

By training young people to be business minded and equipping them with requisite entrepreneurship skills as well as giving them exposure to mix and mingle with successful business people, we are empowering young people, we are challenging them to also follow suit and thereby promoting community development.

Indeed, the churches also helped congregants to register business companies by inviting officials from the company registry to attend their business workshops to enlighten congregants about the requirements for one to open a company. It was not uncommon for some congregants to register their own companies during the workshops. Indeed, 10 of my interlocutors were assisted to register their companies by their churches. This scenario in part, resonates strongly with the Weberian argument that links Protestantism to the emergence and growth of global capitalism. Therefore, I contend that what the new Pentecostal Church and its teachings and activities do is to trigger and cultivate a business culture and agency for its congregants (Maxwell 2005). Indeed, in follow up conversations and visits to my interlocutors, I observed that many of them took up workshop ideas and business principles taught. They tried to implement these ideas and principles with varying degrees of 
success. I argue that this agency is critical for stimulating socioeconomic development in the community. This finding concurs with observations made by the CDE (2008) cited in van de Kamp (2010) who noted that these churches have become spaces for productive working life and entrepreneurship development. For these churches, promoting entrepreneurship was in part one of the many ways they promoted poverty alleviation and development in the here and now. Indeed, in their study in sub-Saharan Africa, CDE (2008) the noted that Pentecostalism's capacity to foster a Protestant ethic is becoming more pronounced in many African countries, thereby making a significant socioeconomic contribution thereof. Therefore, these entrepreneurship and business training should be understood as an extension of the new PCCs' spiritual warfare against the demons of poverty and underdevelopment in the community and the country at large. In an informal conversation with a youth pastor in one of the new PCCs, he asserted that the reason why the country is still poor is because of the territorial demons of poverty and underdevelopment which are constantly fighting the development efforts of the country.

For this pastor, if these territorial demons are not fought back, then the majority of the people and the country will remain poor. So this church organised weekly prayer vigils, where congregants pray, not only for themselves and their individual prosperity, but also for the country's deliverance from poverty. In fact, in many of the services I attended, people were always urged to 'pray for the country'. Therefore, for these new PCCs, prayer becomes a powerful weapon in the spiritual warfare against the demons of poverty which block the flow of Godly blessings to his children (van Wyk 2014; Gukurume 2018b).

In one of the workshops I attended held at a flamboyant hotel in town, everyone was smartly dressed in sharp suits as if going for a job interview. The workshop was supposed to start at $7 \mathrm{p}$.m. and by 5 p.m., when I arrived there were a few seats remaining. In fact by $5.30 \mathrm{p} . \mathrm{m}$. there was a full house - the venue was packed to capacity. The prophet made a grand entry into the venue to a rapturous applause. He was clad in his trademark six button suit rumoured to be an imported designer suit from an Italian celebrity designer Angelo Galasso. His striped tie matched with a small cloth on the pocket of his suit. With glittering shoes and a golden Rolex watch - the prophet embodied a blessed 'men of God'. Indeed, he was not only an inspiration, but also a role model for many of his youthful congregants. Jonathan, one of my interlocutors whom I had gone with, whispered in my ear; 'Look at his clothes, this man knows how to dress - he imports everything from Europe and America - he doesn't wear local and that is what I would like to do in the future'. He smiled admiringly as the prophet grabbed his iPad from the podium to begin the workshop. The prophet extended a warm welcome to everyone in attendance and began with a powerful prayer with a message that centred on dominion, success, being fruitful and finding breakthrough. The theme of his talk was 'Finding your purpose'. He emphasised that God created everyone with unique capabilities, hence the need to live one's purpose. He shouted: 
I want to tell you that God created you for a reason; each and every one of you here has a purpose. Some people are poor because they are not living their purpose, the moment you discover and start to live your purpose; your life will begin to flourish - you will begin to succeed in your business, in your career and you live happily with your family. I want to help you to find your purpose today. I declare that by the time we end this workshop everyone will be placed in their positions, you will have discovered your purpose in life.

As the prophet made these declarations, there was a deafening noise as people shouted loudly, 'I receive, I receive, I will find my purpose today'. In that workshop and indeed in many other services I attended, congregants were urged to think beyond being employees but to imagine themselves as employers. Such teaching fostered a culture of self-belief and self-reliance among the congregants. Therefore, rather than passively accepting their miserable conditions, people actively worked to change their situations through action. Interestingly, some of the new PCCs did not stop at teaching entrepreneurship; they often invited officials from the company registry to speak in church on how to register companies. During my fieldwork, one of the new PCCs helped its congregants to open companies at subsidised rates and many of my youthful congregants opened companies. The act of opening a company even when the majority of my interlocutors could hardly afford to take care of themselves should be understood within the context of spiritual warfare and the symbolic meaning attached to it. In fact, the story of one of my interlocutors is illustrative here.

Peter, one of my key informants was 28 years old during my fieldwork. He had finished his bachelor's degree at the University of Zimbabwe (UZ) four years back but could not get any job. He moved to South Africa with his brother, who like him had been unemployed for six years, to look for a job but returned after several attempts on their lives during the recurrent xenophobic attacks. Upon their return, they joined a new PCC and became ardent members. They started attending the business seminars and workshops organised by the church. Like many other congregants, Peter and his brother also registered their real estate company with the help of the church even though they did not have any start-up capital. They started looking for vacant houses in the newspapers and from church colleagues, which they in turn advertised through Facebook and WhatsApp for a small fee. Towards the end of my fieldwork, they had opened a small office in the Central Business District (CBD) in Harare. Their business was beginning to take shape. Peter narrated to me:

Before I converted to this church my life was a total mess. I tried everything, but nothing worked out. I moved from one company to another looking for a job but in vain. My brother and I decided to go to church after seeing a lot of testimonies of people whose lives changed after joining the church. During the first day at church we manifested demons and the prophet cast them out. We decided to regularly attend the business 
workshops and seminars and before we knew it our lives began to change. I can tell you that now I am not thinking of looking for a job, I am thinking of creating jobs. I am a Chief Executive Officer (CEO) now. When we registered the company we did not have a single cent and some people thought we were berserk, but we had faith that one day God will give us a breakthrough.

Peter's story is just one of the many similar narratives I was told by some of my interlocutors. The story underscores the instrumental impact of faith in motivating people to engage in 'penny capitalism'. These fascinating stories were always shared during church services as testimonies to motivate others trying to make do and get by. Thus, conversion to new PCCs creates new opportunities for upward mobility - though these opportunities are not equally accessible to everyone in the church. However, for those that seize such opportunities as was the case with Peter and his brother, some of them become economically successful. This finding resonates strongly with observations made by some scholars elsewhere (see Freeman 2012, for Ethiopian Pentecostalism; Haynes 2012, for Zambia and van de Kamp 2010, for Mozambique). Scholars like Maxwell have also underscored how new PCCs promote 'penny capitalism' within their membership which often results in wealth accumulation.

'We try to inculcate business skills and knowledge to these young people and to show them that they have great potential to make it in life - to become prosperous business people and to contribute to the development of the country'. A youth pastor told me in an informal conversation. Of note is that new PCCs in Zimbabwe are concerned about the well-being of their congregants and the nation at large and thus making them an extension of the development sphere. Indeed, individual and national transformation is a central theme in new PCCs' discourse and relates strongly to their emphasis on a 'total break with the past' (Meyer 1998; McGovern 2012; Engelke 2010). In new PCC parlance, breaking with the past does not only entails cutting ties with the traditional and extended family ties, it also mean appropriating the 'modern' and orienting oneself to the global. All these help in the socioeconomic transformation of the individual and the society at large.

\section{Bursaries, scholarships and free education for poor students}

An important way new PCCs in Zimbabwe invested in the future generation was through provision of financial assistance to poor students, especially from their church. Churches like UFIC, Spirit Embassy (Good News Church) and PHD to mention just a few had charity organisations which offered bursaries to students from primary level up to university. Though many Pentecostal Churches and their leaders have been criticised for accumulating wealth and becoming rich at the expense of their impoverished congregants (van Wyk 2014; Biri 2012; Mariano 2003; van de Kamp 2010), some of the new PCCs have begun to invest this money in community development and social welfare 
services. Some of my interlocutors at the university of Zimbabwe were beneficiaries of the UFIC's 'Agape Family Care' scholarships. In 2012, UFIC initiated a 'send a child to school' campaign where they encouraged congregants to donate money that would be used to fund their scholarship programmes.

In a context where the imploding and broke state is withdrawing its financial support to the university and students, these new PCCs have thus taken up the vacuum left by the state to provide welfare and financial support to the students. Thus, many of my interlocutors felt that by providing financial support to poor and vulnerable students, the PCCs were ensuring success for them in the future. Although not every beneficiary of the PCC bursaries and scholarships went on to gain employment and succeed in life - some coincidentally became successful and were grateful to the prophets. Thus, by providing bursaries to disadvantaged students, the church is not only investing in future generations, but also redistributing its wealth for the good of the community. Following this, I contend that new PCCs are actively promoting human well-being and socioeconomic flourishing.

After graduation, some of the new PCCs employ the students whose education they funded and other church members. For instance, new PCCs like PHD employed an estimated 1,300 ministry workers (Sibanda 2014). New mega PCCs are thus becoming some of the largest employers in the country where unemployment rates are estimated to be well above 80 per cent (see Gukurume 2015). Through education and employment, new PCCs can thus be said to have meaningful contribution to the development of their members and community at large. In a context where the state is absent or incapable of providing basic services, new PCCs have stepped in to complement the state in social welfare provision. Indeed, Kliksberg (2003) underscored that faith-based institutions offered the most conspicuous and efficacious social protection networks that cushion people from poverty.

\section{Conclusion}

This chapter examined the contribution of new PCCs in promoting sustainable development in Zimbabwe. The chapter shows that new PCCs are becoming important players in the development landscape in the country. By looking at their teachings, prophecies, declarations and activities, this chapter argues that these churches have inculcated and fostered important values of industriousness, sobriety and self-discipline which are important tenets of socioeconomic transformation at individual and collective levels. Thus, by encouraging 'penny capitalism', establishing companies, teaching business skills in their entrepreneurship seminars and workshops, the new PCCs do not only seek to transform their congregants' spirituality, but instead they focus on transforming the 'entire person'. However, it should be underscored that the relationship between new PCCs and sustainable development is complex and contested. Thus, while new PCCs teachings and activities often promote the socioeconomic well-being of the people, not all of them have positive implications for development. In fact, 
some versions of the health and wealth discourses propagated in new PCCs promise spectacular and miraculous wealth and prosperity without members working hard for that. This is akin to what literature calls 'cargo cults' where riches are created from nothing - what the Comaroffs referred to as 'millennial capitalism' epitomised by economics of the occult.

\section{Notes}

1 All the names that I use in this chapter are pseudonyms. The use of pseudonyms is meant to anonymise my participants and keep their identity confidential.

2 This practice has also been called seed faith which urges born again Christians to expect miracles and financial breakthrough and returns for the money sacrificed to the church.

3 www.newsday.co.zw/2017/09/makandiwa-court-fake-prophecy/www.thestandard. co.zw/2017/10/08/makandiwa-prophecies-challenged/.

4 www.sundaymail.co.zw/makandiwa-vs-millionaire-couple\%E2\%E97\%86-messy-tussleover-us $1 \mathrm{~m}-\% \mathrm{E} 2 \% 97 \% 86$-we-were-robbed-abused/.

5 www.herald.co.zw/the-birth-of-a-giant-vp-mohadi-officially-opens-yadah-marble/.

6 www.herald.co.zw/the-billionaires-mindset/.

\section{References}

Adogame, Afe. 2004. 'Engaging the Rhetoric of Spiritual Warfare: The Public Face of Aladura in Diaspora.' Journal of Religion in Africa 34, no. 4: 493-522.

Anderson, Allan. 2004. An Introduction to Pentecostalism: Global Charismatic Christianity. Cambridge: Cambridge University Press.

Barbalet, Jack. 2008. Weber, Passion and Profits: 'The Protestant Ethic and the Spirit of Capitalism' in Context. Cambridge: Cambridge University Press.

Barrett, David. 2001. World Christian Trends, AD 30-AD 2200. Pasadena: William Carey.

Berger, Peter L. 2010. 'Max Weber is Alive and Well, and Living in Guatemala: The Protestant Ethic Today.' The Review of Faith and International Affairs 8, no. 4: 3-9.

Biri, Kudzai. 2012. 'The Silent Echoing Voice: Aspects of Zimbabwean Pentecostalism and the Quest for Power, Healing and Miracles.' Studia Historiae Ecclesiasticae 38, supplement: 37-55.

Burgess, Richard. 2009. 'African Pentecostal Spirituality and Civic Engagement: The Case of the Redeemed Christian Church of God in Britain.' Journal of Beliefs and Values, 30, no. 3: 255-273.

CDE. 2008. Under the Radar: Pentecostalism in South Africa and its Potential Social and Economic Role. Johannesburg: Centre for Development and Enterprise.

Chitando, Ezra, and Kudzai Biri. 2016. 'Walter Magaya's Prophetic Healing and Deliverance (PHD) Ministries and Pentecostalism in Zimbabwe: A Preliminary Study with Particular Reference to Ecumenism.' Studia Historiae Ecclesiasticae 42, no. 2.

Chitemba, Brian. 2017. 'Makandiwa vs Millionaire Couple - Messy Tussle over US $\$ 1 \mathrm{M}$ - We were Robbed, Abused.' Sunday Mail. Accessed 10 October, 2017. www. sundaymail.co.zw/makandiwa-vs-millionaire-couple\%E2\%97\%86-messy-tussle-overus1m-\%E2\%97\%86-we-were-robbed-abused/amp.

Coleman, Simon. 2002. The Faith Movement: A Global Religious Culture? Culture and Religion, 3: 3-19.

Comaroff, Jean, and Comaroff, John L. 2000. 'Millennial Capitalism: First Thoughts on a Second Coming.' Public Culture 12, no. 2: 291-343. 
Cox, Harvey. 1995. Fire from Heaven: The Rise of Pentecostal Spirituality and the Reshaping of the Religion in the Twenty-first Century. Reading, MA: Addison-Wesley.

Deneulin, S. 2009. 'Advancing Human Development: Values, Groups, Power and Conflict.' WeD Working Paper 09/49.

Deneuilin, S. and Rakodi, C. 2011. 'Revisiting Religion: Development Studies Thirty Years On.' World Development, 39, no. 1: 45-54.

Engelke, Matthew. 2010. 'Past Pentecostalism: Notes on Rupture, Realignment, and Everyday Life in Pentecostal and African Independent Churches.' Africa 80, no. 2: 177-199.

Freeman, Dena. 2012. 'The Pentecostal Ethic and the Spirit of Development.' In Pentecostalism and Development: Churches, NGOs and Social Change in Africa, edited by Dena Freeman. London: Palgrave Macmillan.

Freeman, Dena. 2015. 'Pentecostalism and Economic Development in Sub-Saharan Africa'. In The Routledge Handbook of Religions and Global Development, edited by Emma Tomalin. Abingdon, Oxon, UK: Routledge.

Ganiel, Gladys. 2009. 'Spiritual Capital and Democratization in Zimbabwe: A Case Study of a Progressive Charismatic Congregation.' Democratization 16, no. 6: 1172-1193.

Gifford, Paul. 1998. African Christianity: Its Public Role. London: Hurst.

Gifford, Paul. 2004. Ghana's New Christianity: Pentecostalism in a Globalising African Economy. London: Hurst.

Gukurume, Simbarashe. 2015. 'Livelihood Resilience in a Hyperinflationary Environment: Experiences of People Engaging in Money-Burning (kubhena mari) Transactions in Harare, Zimbabwe.' Social Dynamics 41, no. 2: 219-234.

Gukurume, Simbarashe. 2017. 'Singing Positivity: Prosperity Gospel in the Musical Discourse of Popular Youth Hip-Hop Gospel in Zimbabwe.' Muziki 14, no. 2: 36-54.

Gukurume, Simbarashe. 2018a. Navigating Precarious Livelihoods: Youth in the SME Sector in Zimbabwe. IDS Bulletin 49, no. 5: 89-104.

Gukurume, Simbarashe. 2018b. 'New Pentecostal Churches, Politics and the Everyday Life of University Students at the University of Zimbabwe.' PhD thesis, University of Cape Town, South Africa.

Haynes, J. 2007. Religion and Development: Conflict or Cooperation? Basingstoke: Palgrave Macmillan.

Haynes, Naomi. 2012. 'Pentecostalism and the Morality of Money: Prosperity, Inequality, and Religious Sociality on the Zambian Copperbelt.' Journal of the Royal Anthropological Institute 18, no. 1: 123-139.

Haynes, Naomi. 2015. 'Egalitarianism and Hierarchy in Copperbelt Religious Practice: On the Social Work of Pentecostal Ritual.' Religion 45, no. 2: 273-292.

Hollenweger, Walter. 1997. Pentecostalism: Origins and Developments Worldwide. Peabody: Hendrickson.

Honwana, Alcinda. 2014. 'Waithood: Youth Transitions and Social Change.' In Development and Equity: An Interdisciplinary Exploration by Ten Scholars from Africa, Asia and Latin America, edited by Dick Foeken, Ton Dietz, Leo de Haan, and Linda Johnson. Leiden: Brill.

Hunt, Stephen. 2002. 'The "Health and Wealth" Gospel in the UK: Variations on a Theme.' Culture and Religion: An Interdisciplinary Journal 3, no. 1: 89-104.

Jorgensen, Dan. 2005. 'Third Wave Evangelism and the Politics of the Global in Papua New Guinea: Spiritual Warfare and the Recreation of Place in Telefolmin.' Oceania 75: 444-161. 


\section{Simbarashe Gukurume}

Kliksberg, Bernardo. 2003. Social Justice: A Jewish Perspective. Jerusalem: Gefen Publishing House.

Laiton, C. 2017. 'Makandiwa Prophecies Challenged.' The Standard, 8 October. (accessed 20 January 2019).

Lewison, Elsie. 2011. 'Pentecostal Power and the Holy Spirit of Capitalism: Re-imagining Modernity in the Charismatic Cosmology.' Symposia 3, no. 1: 31-54.

Mariano, Ricardo. 2003. 'Brésil.' In Les Nouveaux Conquérants de la Foi. L'Église Universelle du Royaume de Dieu (Brésil), edited by André Corten, Jean-Pierre Dozon, and Ari Pedro Oro, 45-55. Paris: Karthala.

Martin, David. 1990. Tongues of Fire: The Explosion of Protestantism in Latin America. Oxford: Blackwell.

Martin, David. 2002. Pentecostalism: The World Their Parish. Oxford: Blackwell.

Marshall, R. 1993. 'Power in the Name of Jesus: Social Transformation and Pentecostalism in Western Nigeria Revisited.' In Ranger, T. and Vaughan, O. (Eds). Legitimacy and the State in the Twentieth Century Africa. Oxford: Macmillan.

Marshall, Katherine, and Lucy Keough. 2004. Mind, Heart, and Soul: In the Fight Against Poverty. Washington, DC: The World Bank.

Maxwell, David. 1998. 'Delivered from the Spirit of Poverty?: Pentecostalism, Prosperity and Modernity in Zimbabwe.' Journal of Religion in Africa 28, no. 3: 350-373.

Maxwell, David. 2000. 'Catch the Cockerel Before Dawn: Pentecostalism and Politics in Post-Colonial Zimbabwe.' Africa 70, no. 2: 249-277.

Maxwell, David. 2005. 'The Durawall of Faith: Pentecostal Spirituality in Neo-Liberal Zimbabwe.' Journal of Religion in Africa 35, no. 1: 4-32.

McClung, Grant. 2006. 'Pentecostals: The Sequel. What Will It Take for this Global Phenomenon to Stay Vibrant for Another 100 Years?' Christianity Today 50, no. 4: 30-36.

McGovern, Mike. 2012. 'Turning the Cloak Back or Breaking with the Past: Charismatic Temporality and Elite Politics in Cote d'Ivoire and the United States.' Cultural Anthropology, 27, no. 2: 239-260.

Meyer, Birgit. 1998. 'Make a Complete Break with the Past: Memory and Post-Colonial Modernity in Ghanaian Pentecostalist Discourse.' Journal of Religion in Africa 27, no. 3: 316-349.

Miller, Donald E. 2009. 'Progressive Pentecostalism: An Emergent Trend in Global Christianity.' Journal of Beliefs $\mathcal{E}$ Values: Studies in Religion $\mathcal{E}$ Education 30, no. 3: 275-287.

Miller, D. and Yamamori, T. 2007. Global Pentecostalism: The New Face of Christian Social Engagement. University of California Press.

Musoni, Phillip. 2013. African Pentecostalism and Sustainable Development: A Study on the Zimbabwe Assemblies of God Africa, Forward in Faith Church. International Journal of Humanities and Social Science Invention 2, no. 10: 75-82.

Pasura, Dominic. 2012. 'Religious Transnationalism: The Case of Zimbabwean Catholics in Britain.' Journal of Religion in Africa 42: 26-53.

Robbins, Joel. 2004. 'The Globalization of Pentecostal and Charismatic Christianity.' Annual Review of Anthropology 33: 117-143.

Sachiti, Roselyne. 2018. 'The birth of a giant ... VP Mohadi officially opens Yadah Marble.' The Herald, 21 February, 2018. www.herald.co.zw/the-birth-of-a-giant-vpmohadi-officially-opens-yadah-marble/.

Sibanda, Lloyd. 2014. 'Prophet Magaya goes for 200,000-seater church, to give away 420 houses.' My New Zimbabwe. 8 August 2014. Accessed 20 July 2019.

Singerman, Diane. 2007. 'The Economic Imperatives of Marriage: Emerging Practices and Identities among Youth in the Middle East.' Middle East Youth Initiative Working 
Paper 6. Washington, DC: Wolfensohn Center for Development, The Brookings Institution.

Taru, Josiah, and Federico Settler. 2015. 'Patterns of Consumption and Materialism among Zimbabwean Christians: A Tale of Two Indigenous Churches.' Journal for the Study of Religion 28, no. 2: 113-137.

Ter Haar, Gerrie, and Stephen Ellis. 2006. 'The Role of Religion in Development: Towards a New Relationship Between the European Union and Africa.' The European Journal of Development Research 18, no. 3: 351-367.

Togarasei, Lovemore. 2012. 'Mediating the Gospel: Pentecostal Christianity and Media Technology in Botswana and Zimbabwe.' Journal of Contemporary Religion 27, no. 2: 257-274.

Tyndale, W. 2001. 'Poverty and Development: Has Religion a Contribution to Make.' Commentary International Movement for a Just World, 1, no 2: 1-5.

Tyndale, W. 2006. Visions of Development: Faith-based Initiatives. Aldershot: Ashgate.

Ukah, Asonzeh F. K. 2003. 'Redeemed Christian Church of God, Nigeria: Local Identities and Global Processes in African Pentecostalism.' $\mathrm{PhD}$ thesis, Universität Bayreuth.

Ukah, Asonzeh F. K. 2007. 'African Christianities: Features, Promises and Problems.' Working paper, Institut für Ethnologie und Afrikastudien, Johannes GutenbergUniversität Mainz.

van de Kamp, Linda. 2010. 'Burying Life: Pentecostal Religion and Development in Urban Mozambique.' In Development and Politics from Below. Exploring Religious Spaces in the African State, edited by Barbara Bompani, and Maria Frahm-Arp, 152-171. Basingstoke: Palgrave Macmillan.

Van Dijk, Rijk A, 1997. 'From Camp to Encompassment: Discourses of Transsubjectivity in the Ghanaian Pentecostal Diaspora.' Journal of Religion in Africa 27, no. 2: 135-159. van Wyk, Ilana. 2014. The Universal Church of the Kingdom of God in South Africa. A Church of Strangers. Cambridge: Cambridge University Press.

van Wyk, Ilana. 2015. 'Prosperity and the Work of Luck in the Universal Church of the Kingdom of God, South Africa.' Critical African Studies, 7, no 3: 262-279.

Weber, Max. 1930. The Protestant Ethic and the Spirit of Capitalism. Trans. Talcott Parsons. New York: Charles Scribner's Sons. 


\title{
19 Pentecostal Charismatic Christianity and the management of precarity in postcolonial Zimbabwe
}

\author{
Josiah Taru
}

\section{Introduction and background}

This chapter starts with a commentary on the conceptualisations of, and common narratives produced by, researchers that explore the intersection between Pentecostalism, modernity and development in Africa. The rest of the chapter focuses on the political and economic crisis in postcolonial Zimbabwe and ways in which One Ministry of God (OMG) is assisting its members to respond to the crisis. Finally, some conclusions are derived from the discussions and examples raised in the chapter. The main argument furthered in this chapter is that some variants of Pentecostal Charismatic Christianity have oriented their activities in a way that cushions their members from the vagaries of the multi-layered Zimbabwean political and economic crises.

Several studies have portrayed Pentecostal movements as responding to objective realities of neo-liberal capitalism (Comaroff and Comaroff 2001), modernity (Meyer 1998a; Comaroff and Comaroff 1997) and political and economic crises (Gifford 2002, 2009, 1994) through spiritual means. Pentecostalism is portrayed as a vehicle of spiritualising and enchanting situations and problems that characterise some African postcolonial states. Drawing from ethnographic data gathered from One Ministry of God $(\mathrm{OMG})^{1}$ in Zimbabwe, this chapter shows that $\mathrm{OMG}$ has instituted pragmatic strategies to deal with state-induced precarity and vulnerability. There are efforts being made to improve the lives of members in the 'here and now' through pragmatic ways.

The data presented in this chapter was gathered through ethnographic fieldwork spanning from June 2016 to August 2018. Most of the data was gathered through in-depth interviews conducted with 55 OMG members, and from field observations. Furthermore, the researcher stayed with a family that was part of the OMG. This facilitated observations of everyday lives of Pentecostal Charismatics, especially ways in which the teachings at $\mathrm{OMG}$ are incorporated in guide decision-making. The researcher attended and took part in most of the church services and events organised by OMG. Lastly, some of the data presented in this chapter was acquired from sermons, OMG literature, newspaper articles, DVDs and CDs. 


\section{Religion, modernity and development}

The emphasis on science as the only way of understanding our world during the enlightenment project portrayed religion as militating against progress. Oftentimes religion is relegated to the realm of the metaphysical which has little bearing on the realities of the members within religious communities. Most conceptualisations of religion emphasise the irrational, mysticism and supernatural nature of religion (Asad 1993, 27-54; Coleman 2011; Marshall-Fratani 2014). Modernisation theorists portray religion as an atavistic form of knowledge with little significance in issues of progress and development. Concomitantly, religion is overlooked in most developmental processes. Modernisation theorists construct development as planned, rational and future oriented and religion as the opposite. The differences in the conceptualisations of religion and development gives a false sense of incompatibilities between the two realms. As Scott (1998) and Ferguson $(1999,2006)$ have shown, modernity and development projects have produced unintended consequences undermining the rational and planned aspects that are over-emphasised by modernisation perspective and western discourse on development.

Weber (1930) argues that Calvinism was the handmaid in the development of capitalism in Europe. Calvinism encouraged values of saving, hardworking, asceticism and thriftiness among its members (Lessnoff 1994). These values guaranteed material prosperity which was considered as a visible sign for salvation (Samuelsson 1957). Weber avers that Calvinists' Protestant ethics were instrumental in the development of capitalism as an economic system. Scholars continue to search for the role of religion in developing ethos that have a bearing on social and economic development. Studies conducted in Southern Africa are starting to acknowledge the role of religion, especially Pentecostalism as conduit for social and economic development (Freeman 2015). Lawrence Schlemmer's (2008) and Peter Berger's (2008) research papers, titled Dormant Capital and Under the Radar respectively, bring to the fore the potential social and economic significance of Pentecostalism in South Africa. Pentecostal movements are engaging in a number of projects that have a bearing in the development of surrounding communities. Furthermore, Pentecostal Charismatic Christianity engages in several charity activities that enable marginalised members of society to lead decent lives (Miller and Yamamori 2007).

\section{Theological and missiological orientations of PCC}

The term Pentecostal Charismatic Christianity has been used to distinguish contemporary PCCs from the first wave Pentecostal movements that emphasised holiness. The emergent variant of Pentecostalism has been identified as the Third Wave of Pentecostal movements, Neo-Pentecostalism and new churches (Gifford 2004, vii). I follow Robbins' (2004, 117) and Meyer's (2007) usage of the term Pentecostal Charismatic Christianity to refer to Pentecostal movements whose teachings involve elements of prosperity gospel, entrepreneurship 
and are accommodative of material and financial success. Pentecostal Charismatic movements have shifted their discourse from the premillennialism widely found among classical Pentecostalism. ${ }^{2}$ Classical Pentecostal theology is premillennial in nature, stating that Jesus Christ will establish and reign over an earthly kingdom for a millennium. ${ }^{3}$ The established earthly kingdom will replace the one we are part of (Wacker 2001). Premillennial theology encourages retreatism in early Pentecostals (Wacker 2001). The bulk of classical Pentecostal movements concerned themselves with directing believers towards issues that will guarantee them life after death spiritual issues (Wacker 2001, 217-219; Christerson and Flory 2017, 92).

PCC have adopted postmillennial theology in which religious movements are concerned with and involved in 'creating a heaven on earth' (Christerson and Flory 2017, 92). Postmillennial theology promotes a 'dominionist' stance in believers, by encouraging believers to take-over the world and re-fashion the world in a way that pleases God (Christerson and Flory 2017). PCC are involved in world-making (Marshall 2009; Robbins 2004, 130) with the imageries preached informing the actions that the Pentecostal Charismatics engage in to create the world projected in the teachings and imageries (Meyer 2010, 118). PCC are interested in the 'here and now', positioning religious movements in a space in which they must deal with some of the effects of the poorly performing Zimbabwean state-systems.

\section{One Ministry of God: theological and missiological orientations}

The Zimbabwean religious landscape has experienced an increase in the number of PCCs over the past two decades (Chitando 2009; Taru and Settler 2015). PCC have increased in both numbers and public visibility. OMG is one such PCC which is visible on Zimbabwean religious landscape.

$\mathrm{OMG}$ is a religious movement that has managed to tremendously grow in terms of membership and branches. OMG membership is drawn from the crosssection of the Zimbabwean society. Business executives, politicians, small business owners, informal traders, the unemployed and vendors constitute the bulk of OMG members. Founded by Prophet Ben ${ }^{4}$ as a lunch-hour interdenominational prayer session, $\mathrm{OMG}$ has rapidly grown into a transnational movement. OMG's website claims that over 70,000 people attend its services per week (OMG website, accessed in June 2017). The mission of OMG is spelt out as 'to Build A God Society for All People and All Nations and Reaching Out'. OMG members view themselves as the chosen people tasked with creating a society on behalf of God. OMG members believe that the 'God society' will be built in the 'here and now'. On its website OMG claims that it seeks to 'enact a revolution' by equipping members with skills, knowledge and information 'relevant to every 21st Century Believer'. The mission to build the 'God society' will not be achieved spiritually but physically through the efforts by both OMG and its members. The drive towards constructing a 'God society' is guided by the need 
to create conducive societies 'in which people can flourish and live life abundantly'5 (Fieldnotes 7 January 2017).

Prosperity gospel comes in many strands, often retooled to suit the local cultural, political and economic context within which the gospel is preached (Haynes 2012). From the sermons preached by Prophet Ben, prosperity includes spiritual, physical and material well-being that enhances the standard of living for congregants. During a service Prophet Ben told congregants that they 'were not created to live in any form of deprivation' (Prophet Ben, sermon, 26 August 2017). Similar proclamations from the pulpit are common. In 2016 Prophet Ben informed the congregants that God gave OMG members dominion over the earth so that the congregants can flourish unfettered by anything (Prophet Ben, sermon, 24 July 2016). Furthermore, OMG's devotional booklet contained similar teachings that encourage $\mathrm{OMG}$ members to dominate in some aspects of their lives. In the same devotional booklets, the prophet wrote that 'He (God) never wanted you to suffer ...' (OMG Devotional booklet, 12 June 2017). These teachings explicitly reveal that God aims to richly reward OMG Pentecostals in whatever form they want it, be it health, family, business success, employment, houses and vehicles. The teachings shape ways in which OMG members construct their personhood and how they understand their position in the world. This dominionist theology must be understood within the Zimbabwean context.

\section{Precarity and uncertainties in postcolonial Zimbabwe}

Anthropologists distinguish between precariousness and precarity to capture the everyday experiences of people living in conditions of insecurities and vulnerability (see Butler 2004). Humanity exists in condition of precariousness because of unavoidable vulnerability and insecurities that come as a result of our shared existence. Precariousness is part of our collective lives. The concept of precarity points to 'specific way that socio-economic and political institutions ... distribute the conditions of life inequality' differently to people (Millar 2017, 4). The source of precarity is mismanagement of and by institutions that have a direct bearing on the lives of people. Precarity is characterised by a 'life without the promise of stability' (Tsing 2015, 2). In the case of Zimbabwe, precarity is a result of ill-governance by the postcolonial government, whose policies have heightened vulnerability, insecurities, hopelessness, anxiety and despair among Zimbabweans (Rotberg 2002, 94; Jones 2010).

From the 1990s multi-layered political and economic crises have dogged the postcolonial Zimbabwean state. The adoption of the neo-liberal Economic Structural Adjustment Programme (ESAP) in the 1990s increased vulnerability and insecurity among the bulk of Zimbabweans. Poverty levels rose to such high levels that in the United Nations Human Development Report of 2010 Zimbabwe ranked at the bottom. For the past two decades, the economic situation in Zimbabwe has been worsening, with the GDP halving in a decade (Majengwa, Kasirye and Matema 2012). Inflation rates jumped from 49 per cent 
in 2000 to $231,000,000$ per cent in 2008 (Gono 2008a; 2008b). High inflation rate reduced disposable income and eroded savings. The local currency lost its value and was demonetised. The introduction of the multi-currency in 2009 introduced a degree of stability in the economy. The United States Dollar (US\$) was the preferred currency with prices pegged in United States Dollars and banks dispensing United States Dollars (Kanyenze, Chitambara, and Tyson 2017, 7). However, by 2015 United States Dollars were in short supply and the government introduced bond notes. ${ }^{6}$ As of 2014 the informal employment rate had escalated to over 94 per cent (Kanyenze, Chitambara and Tyson 2017, 1). The worsening economic conditions led to the informalisation of the economy, pushing the bulk of Zimbabweans into the informal economy (Jones 2010). The state exacerbated the situation by unleashing the police and the military to destroy informal marketplaces and get rid of the informal economy through 'clean-up' operations (Tibaijuka 2005).

In 2005 the government embarked on Operation Murambatsvina ${ }^{7}$ which destroyed houses and informal markets that the majority of urbanites depend on. 92,460 houses were demolished leaving more than 134,000 people homeless (Tibaijuka 2005). During Operation Murambatsvina, the government also destroyed means of livelihoods for most urbanites by destroying informal marketplaces. The operations left most Zimbabweans without home or source of livelihood. Urbanites were displaced into rural areas. The palliative Operation Garikayi/Hlalani Kuhle ${ }^{8}$ provided fewer houses than those demolished during Operation Murambatsvina. Below I will discuss ways in which OMG has organised its members into a housing cooperative aimed at assisting OMG members to secure places of residence.

State institutions are responsible for the suffering of most Zimbabweans. As the state fails in creating a conducive environment for Zimbabweans to lead decent lives, most Zimbabweans are turning to self-help projects. Religious movements, housing cooperatives, burial societies and rotating credit schemes have increased in the last two decades. In the face of inadequacies of the state welfare system and policies, citizens are shifting their attention away from the state and are looking towards alternative institutions for assistance in improving livelihood and well-being.

\section{Pentecostal personhood and well-being}

The act of converting to $O M G$ and being baptised is read as the first victory one scores against witchcraft, poverty and sinful life (cf. Maxwell 1998 on converts who joined Zimbabwe Assembly Of God Africa, ZAOGA). New converts are reminded that their choice to follow Jesus is not easy, there are opposing ancestral and satanic forces that have to be overcome. From the onset, converts are portrayed as victors in the spiritual warfare against witchcraft and demonic forces. Baptism is one ritual that physically conveys the symbolic changes in the personhood of the converts. For OMG members, the act of being immersed in water and re-emerging signals death of the old self and the emergence of the 
new self, empowered by the Holy Spirit. These transformations are evident in the narratives of some of the congregants. One OMG member narrated that:

when I converted in 2012, I was following my friends who were already members of OMG.... It was only after being baptised that I thought carefully about being a Christian. We were taught what baptism mean for Christians ... it was a way of reconnecting to our source - God. Once we are in good books with the source, what will I lack? The teachings helped me to leave my old habits. I learnt that God loves us and that we are of importance to Him. We are closer to His image than angels, we are more important to God and we must never look down upon ourselves.

(interview, 2 September 2016)

Baptism is a ritual that facilitates OMG members 'break with the past' (see Meyer 1998b). As pointed out in the above excerpt, conversion is a process of rejuvenation and anchoring one's life. God becomes the anchor in converts' lives. The new relationship with God is instrumental in shaping OMG's members perception of themselves. OMG Pentecostal Charismatics conceive themselves as victors who have a direct link to the source of life - God. The construction of selfhood around ideas of victory is furthered in Eucharist rituals in which members embody the blood and body of Jesus. Among OMG members the blood of Jesus is considered so powerful that it can heal any form of sickness, defeat demons and witchcraft that works against members' prosperity. These rituals endow OMG members with confidence and optimism on most issues that they participate in. Apart from rituals, the message in most $O M G$ songs is optimistic (Gukurume 2017).

Apart from cultivating personal relationships with God, OMG members develop relationships among themselves. OMG provides fertile ground for the emergence of social networks of support and opportunities among members. Members are organised into section and zonal groups. These groupings allow for the development of intimate relationships among members because the groups are small and based on residential locations. Social relations based on religious affiliation form social and economic capital that individuals depend on in improving their lives. A member of OMG who owned a hardware store relied on purchases by builders and plumbers who are members of OMG. The builders always brought their clients to this hardware store. The preference to buy from a fellow Pentecostal Charismatic attests to the intimate bonds developed by members. OMG-based social networks provided by the groupings are also important for members in the informal economy. The social networks double as business networks, as clients and suppliers are derived from the members of the small groupings. OMG members prefer obtaining services and products from fellow church members. OMG members from different social and economic classes form social relationships through sectional and zonal groupings that meet during mid-week gatherings. Social networks provide support, love and care that cushion members from the vagaries of the economic crisis (Clarke 1994, 
216-217). The groupings focus on addressing spiritual, social, economic and health issues that affect members.

\section{New subjectivities: rationalisation and methodical lives}

Weber (1930) argues that Calvinism brought with it a rationalising and systematic approach to life. This allowed for the emergence of ethics that laid the foundation for capitalism. The practices Weber describes are being reproduced by OMG Pentecostal Charismatics. OMG instils methodical approaches to congregants' lives through various strategies. As I have alluded to above, baptism represents a break with one's past. The break is both spiritual and physical. Pentecostal movements' close-knit religious communities are instrumental in changing the lifestyle of members. David Maxwell (2006) notes male members of ZAOGA transformed from profligate lifestyle of alcohol consumption, extra marital liaisons and funding traditional rituals to supporting relatives. Pentecostalism, in the case of ZAOGA, encouraged frugal lifestyles supported by the meagre income members earned. Furthermore, the reduction in alcohol consumption and support given to relatives and sexual partners translated into increased attention given to the immediate family. The focus on the immediate family produced family structures that are often associated with the middleclasses. In the case of ZAOGA. Pentecostalism promotes stable families whose members focus on improving their lives. $O M G$ is reproducing similar values and practices. OMG discourages extra-marital affairs, smoking and drinking among its members. In one of the church services I attended in 2016 Prophet Ben exposed a member who engaged in an extra marital affair (fieldnotes, June 2016). ${ }^{9}$ Publicly exposing unfaithful members during service acts as a social control mechanism to discourage other members. OMG organises family days and events for couples to strengthen the family unit. The focus on the immediate family and distant relatives reduces expenditures on activities that do not directly benefit the family.

OMG has inculcated members with methodical approaches on issues concerning money and time management. For OMG Pentecostals time dedicated to anything can translate to money. OMG members either contribute money or time to OGM. These two types of donations are treated in the same manner. Due to this most members manage their time diligently because they know its value. Also, a number of respondents referred to what they called 'The Kingdom Prosperity model' that guides members on issues of money, investment and savings. The model brings rationalisation when it comes to financial matters. For every dollar earned, 10 per cent is set aside for tithe (interview, 29 September 2016). Apart from the 10 per cent reserved for tithe, 20 per cent is earmarked for business projects that the congregants have interest in. Some congregants fund cross-border trading, vending and fast-food businesses from the 20 per cent. The remaining 70 per cent is for congregants' free-will offerings ${ }^{10}$ and consumption. The model instils systematic expenditure and planned use of money. The model promotes the culture of saving with the aim of starting income generating projects. Furthermore, 
the model encourages $\mathrm{OMG}$ members to be entrepreneurial as a certain amount of income is reserved for and dedicated to income generating projects. The model applies to all congregants regardless of their variations in income levels. Those that earn less will save less and are thus more likely to engage in small businesses such as vending. While the model exists, there are some congregants who failed to put the model into practice due to erratic and meagre incomes. Despite the failure to follow the model, several congregants expressed their willingness to follow the model once stability returns into their lives.

Deborah James $(2015,2012)$ found that in South Africa, Pentecostalism has moulded black South Africans into the habit of saving through teachings that equip them with financial management skills. Some of the Pentecostal Charismatic Christianity in Sub-Saharan Africa are promoting rationalisation and methodical lifestyles that positively impact the livelihood of members and their families. The methodical lifestyles are mechanisms through which families adjust to the economic realities obtained in Zimbabwe and the meagre disposal income that most households and families survive on. The Kingdom Prosperity model optimises income by earmarking and compartmentalising the income into categories that the members have to satisfy. There is long-term standardisation of expenditure on things that are considered important by congregants. Budgets drawn by some of the members I interviewed showed a sustained focus on funding income generating projects and on household provisions. The concomitant result of organising expenditure along the model is that it brings a methodical way of spending and saving congregants' finances.

There is a general consensus among OMG Pentecostals that money and wealth do not affect one's spirituality. From the sermons by Prophet Ben and interviews with members, OMG Pentecostals do not consider money and consumption as corrosive to spirituality. Money and wealth are creatively incorporated into $\mathrm{OMG}$ theology and liturgy. A male interviewee noted that

Christians must be wealthy, more wealth than heathens. Jesus was wealth, soldiers fought for his robes after his crucifixion.... Money on its own is not evil, rituals performed on the money may be evil. If money is evil, why is it that more than half of Jesus' parables are about money?

(interview, 17 June 2016)

OMG members accept money as neutral and value-free. This theological stance encourages OMG Pentecostals to actively seek money among other things. Studies among some American Protestant movements have shown that believers are forced to withdraw from wealth accumulation and conspicuous consumption as these two are thought to interfere with spiritual growth (see Sorokin 1992; Schwartz 1994; Stillman et al. 2012). Acceptance of money as a neutral medium of exchange and store of value produces an elective affinity towards amassing of wealth. OMG Pentecostals seek money and wealth openly without fear of being labelled materialistic. For OMG members, amassing money is a sign of divine blessings. 


\section{Josiah Taru}

To enhance members' possibility of flourishing, OMG partnered Old Mutual financial services ${ }^{11}$ to train members in financial literacy. Furthermore, OMG organises business conferences and workshops meant to teach congregants about financial and investment management. OMG makes deliberate efforts to invest in developing congregants' financial intelligence, especially bookkeeping and basic accounting. These workshops inculcate skills and knowledge that are essential for both households and business budgeting. As mentioned, some of the families kept records of expenditures and income. In some families the purchases of foodstuff, clothes and other items is planned and diarised. One of the booklets provided to OMG members by Old Mutual tackled issues of financial planning, financial vision and building asset base. The booklet is written in a highly accessible way to cater for congregants from different economic and educational background. Most of the lessons are presented as allegories derived from animals. ${ }^{12} \mathrm{OMG}$ is tapping into the expertise of corporates to provide training and support for its members. OMG does not rely on spiritual approaches to improve the livelihood of its members, it is partnering with corporates that understand the operations of the economy and of money.

\section{Entrepreneurship and formalisation}

Empowerment is a buzzword in Zimbabwe, with both government, civil society and churches moulding their approaches around the concept of empowerment. Despite the government's efforts towards empowering citizens, the ZANU PF-led government has failed. During the 2013 elections ZANU PF manifesto rested on three pillars namely: Indigenize, Empower and Develop. The actions and policies of the ZANU PF government are contrary to these values. The government went on to demolish the informal market and criminalise income generating activities that supported the bulk of Zimbabweans in the urban areas. OMG has taken it upon itself to empower and develop its members by supporting small business enterprises operated by members. The bulk of PCC in Zimbabwe are incubators for nurturing small businesses owned by members. Maxwell (2006) notes that ZAOGA spurred entrepreneurship through the 'talents initiative'. Pentecostals were encouraged to expand sources of income by running side-business ventures. Most of the business ventures were compatible with the formal employment. Maxwell (2006) sums that Pentecostalism promotes 'penny capitalism' whose proceeds supplement income from formal employment.

ZAOGA is one of the oldest local Pentecostal movements established in Zimbabwe and most of its members were formally employed in the civil service (Maxwell 1999). OMG came into existence when the postcolonial state experienced economic and political crisis. Chances of formal employment have drastically been reduced, leaving graduates with few options. Under such circumstances, $\mathrm{OMG}$ does not promote entrepreneurship as side-business ventures that only complement formal employment, but entrepreneurship is promoted as the main source of income and livelihood. Prophet Ben has encouraged his followers to be entrepreneurial and operate businesses rather 
than search for formal employment. In a sermon Prophet Ben remarked that 'waged employment is form of slavery which must be escaped' (sermon, 26 August 2016). Prophet Ben's message speaks to an obtaining situation in which most industries have collapsed.

OMG further encourages its members to formalise their business enterprises. OMG has facilitated the registration of unregistered companies and businesses operated by its members by subsidising the registration process. Furthermore, $\mathrm{OMG}$ engaged personnel to draft the documents required for registration. One female congregant told me that in $2015 \mathrm{OMG}$ assisted a number of congregants to register their businesses through the drafting of required documents and paying half of the cost involved (interview, 17 February 2017). While most small-scale businesses in Zimbabwe are unregistered, OMG is initiating the transformations of businesses from an unregistered status to a registered status. In a highly informalised economy, the formalisation of businesses comes with several benefits. OMG initiatives of registering businesses lower the level of precarity inherent in the informal economy. Registered businesses can apply for lucrative tenders. Furthermore, registered businesses have access to funds provided by banks and other financial institutions. In this way, OMG's initiative opens business opportunities for members' enterprises. These opportunities are lacking for most businesses that operate in the informal economy.

As highlighted above, $\mathrm{OMG}$ provided capital for some of its congregants to kick-start businesses. The capital was provided to congregants who attended business and financial workshops that are organised. OMG has a number of programmes meant to assist budding entrepreneurs. In August 2016 I attended events such as golf tournaments, breakfasts and lunches organised for the entrepreneurs to meet business executives and business owners. OMG is the conduit through which budding $\mathrm{OMG}$ entrepreneurs are linked to established business executives for mentoring and synergies. OMG provides a gateway through which the entrepreneurs among its members can connect to the business world. Prominent business executives graced the occasions and interacted with OMG Pentecostals.

OMG is fostering a vibrant internal economic community among its membership. While beliefs and rituals unite members into a religious community, an economic community is fostered through church-based business directory. Every year members advertise their businesses in a church-based business directory. The directory creates consumers out of congregants. The directory features businesses owned by members only. Entries into the directory are regardless of the size and type of business one runs. OMG as an organisation and its members prefer to purchase services and products from businesses owned by members. $\mathrm{OMG}$ is currently constructing its headquarters and some of the construction material were acquired from a hardware shop owned by members (interview, 12 August 2016). One of the hardware shop owners noted that OMG paid market prices for the services his company provided. OMG creates a ready market for most congregants' businesses. Congregants in fashion and designing, baking and confectionary as well as in hair styling trade readily find consumers through the 


\section{Josiah Taru}

directory and can provide services during $O M G$ events. $O M G$ is a network of support, opportunities and relations that assist small entrepreneurs to establish themselves in a poorly performing economy.

\section{Moral economy and housing provision}

In 2005 more than a million Zimbabweans were on a government housing waiting list (Tibaijuka 2005). While the state withdrew from social welfare provisioning, most Zimbabwean were forced into the informal settlements as they failed to afford buying houses from private developers. To worsen the situation, those in the informal economy had limited access to loans and mortgages from financial institutions such as banks that offer salary-based loans. The bulk of Zimbabweans remain excluded from accessing decent houses and accommodation. Zimbabweans have organised themselves into housing cooperatives (Chirisa, Gaza and Bandauko 2014; Paradza and Chirisa 2017). The housing cooperatives pose several challenges to members. Most home-seekers are duped of hard-earned money by housing cooperatives' management committees. Furthermore, other housing cooperatives have misled members to construct houses on undesignated land. Mistrust and suspicion between members and management committees characterise most housing cooperatives. Furthermore, the government has demolished housing structures erected on undesignated land..$^{13}$

OMG has organised its members into a housing cooperative. The housing cooperative is organised in a different way to most housing cooperatives in Zimbabwe. Most housing cooperatives are composed of people who come together for the purpose of pooling together resources for the provision of houses. Members often lack prior intimate relations. Cases of housing cooperatives' management committees defrauding members are common in Zimbabwe. The housing cooperative at OMG is constituted by members who already have relations as they are all members of OMG. Furthermore, the moral economy of trust, honesty and piety inform the relations and interactions among members, and between the management committee and the members. The clergy has constructed itself as a caring and honest leadership interested in improving the well-being of members. Furthermore, the belief in God binds the members together. The housing cooperative is an extension of OMG, it is constructed as a moral community in which trust and care are evident. Prophet Ben is the ceremonial patron of the housing cooperative. The moral economy of trust and honesty upheld by members of the OMG housing cooperatives is absent in most housing cooperative in Zimbabwe.

OMG housing cooperative managed to pool together US $\$ 1.4$ million in fifteen months (fieldnotes, September 2017). ${ }^{14}$ Once this substantial amount was raised, the management committee consulted the membership on the way forward. From interviews I gathered, it can be shown that housing cooperative members instructed the management committee to purchase land from a private owner as a way of avoiding procuring land from local authorities and the state. The decision to purchase land from private owners is meant to cushion members 
from insecurities associated with land allocated by the local municipalities and state. ${ }^{15}$ OMG learnt from a misunderstanding that occurred a few years ago when the central government blamed the local municipality for corruptly allocating OMG a place to build its headquarters. To avoid the same pitfall, members are opting to purchase land from a private owner. The housing cooperative has engaged an architecture firm to draw building plans for the houses and to design the OMG city. The housing cooperative is making frantic efforts to transform the goals of homeownership into a reality for its members.

The housing cooperative has been instrumental in helping female congregants in owning houses. One Pentecostal congregant rhetorically retorted:

Who told you that you can't own a house before marriage? Have your own house so that your future spouse will know that you are a focused partner. For wives they can own another house in their names, if funds permit.

(conversation with OMG congregant, 7 January 2017)

When I attended the Annual General Meeting for the project on 7 January 2017, female congregants who had registered for the project outnumbered males. One female congregant could not hide her joy that, after years of renting, the housing cooperative will assist her to own a house. If the project goes according to plan, the houses will be constructed by a building society that has been engaged to construct the houses. Involving the building society would reduce construction of sub-standard structures that would 'spoil the vision and image of the prophet' (conversation with OMG member, 7 January 2017). The existence in Southern Africa of legal, cultural and economic hurdles that mitigates women's access to urban houses is well documented (Goebel 2015, 29). The OMG housing initiative is an attempt to dismantle the historical system that denies low income women from owning houses in their own name.

For OMG Pentecostal Charismatics the construction of the houses goes beyond mere provision of accommodation. It is about parading the nature and type of God they believe in. Lodging and rented accommodation are considered a misrepresentation of the God worshipped by OMG members (Prophet Ben, sermon, June 2016). The establishment of the housing cooperative is a way of making a connection with the ideal society promoted by the clergy in sermons and teachings.

\section{Spiritual security and agency}

Most Pentecostal Charismatic movements' understanding of the world is informed by the belief in spiritual warfare (Maxwell 1998, 2006; Meyer 2005, 2003). OMG is not an exception, its construction of the world is informed by the same beliefs that blame the devil and his agents for most mishaps such as accidents, sickness, unemployment and infertility that some of the congregants experience. The devil is portrayed as a nemesis that works against Pentecostals 
who want to flourish. For OMG Pentecostals, the crucifixion of Jesus is the source of their desire to prosper. The death of Jesus marked a turning point in the lives of believers. Jesus took with him most of the problems that bedevilled humanity: poverty, diseases, sadness and slavery. Despite his death, the devil and its agents continue to inflict humanity with these problems (interview, 23 June 2016). Biblical scriptures are often cited to support the existence of the spiritual warfare. Most interviewees cite John 10 verse 10 which gives a comparison of the devil and Jesus to believers. ${ }^{16}$

There is a sense of 'spiritual insecurity' that characterises the lives of most OMG Pentecostals (Ashford 2005). The devil and its agents are the sources of what Ashford (2005) calls spiritual insecurity. This spiritual insecurity is illustrated in an interview excerpt below:

The devil does not tire my friend, he uses different agents to bring people down, at one time its demons, sickness and other close relatives. Some four years ago, I graduated from university, but I could not find a decent job. I applied to all NGOs that I knew had offices here (Harare) but none even sent a regret letter. Neighbours mocked the prophet because I could not get a job. I was disappointed, I was hopeless. But I remained steadfast in prayer and in my faith, I knew it was the devil's plan to shake my faith ... but I didn't. I increased the intensity of prayers and fasting, I also upped applications for employment. I finally got a job and the devil attacked me through another way, this time my mother, she fell ill. I spent lot of money on her treatment, my income was going towards her medical bills, I was broke yet I was employed.

(interview, 19 December 2016)

The challenges that OMG Pentecostals face are explained in the context of the cosmic struggle between God and the devil. The retooling of the challenges that the Pentecostals encounter and the finding of meaning in spiritual warfare inculcates perseverance in OMG Pentecostals. The fears and challenges that the interviewee expressed are fears that characterise most Zimbabweans. However, OMG Pentecostals frame the challenges in terms of spiritual warfare. Furthermore, OMG Pentecostals identified prayer and fasting as the source of spiritual security and stability. Pentecostal rituals such as fasting, prayers, baptism and Eucharist services were noted to hedge members from the economic and political instabilities prevailing in the wider society. Most OMG Pentecostals feel secure in the 'durawall'17 of faith, network of assistance and ritual that OMG provides for members (cf. Maxwell 2006). This goes beyond spiritualising challenges and problems as described by Gifford (2004) in the case of Ghana.

\section{Conclusion: towards OMG politics of hope}

Writing on culture and by extension religion, ${ }^{18}$ Appadurai $(2013$, 292) laments that anthropologists ignore ways in which 'cultural systems, as combinations of norms, dispositions, practices and histories, frame the good life as a landscape of 
discernible ends and of practical paths to the achievement of those ends'. In our case, OMG has a model of what constitutes good life and often spells out clear strategies for achieving good life. Appadurai $(2013,295)$ conceptualises good life as 'what many people hope to achieve' in order to flourish. Models of good life preached at OMG have the capacity to aspire congregants to desire a good life. The aspirations for health, happiness, decent housing and running successful businesses are not individualistic among OMG members; it is collective and shared. Furthermore, it lays the foundation upon which congregants think about the future. Good life is achieved through ethics of possibilities that give hope for people to continue forging towards improving their lives. Ethics of possibilities is a navigational capacity consisting of 'ways of thinking, feeling and acting that increase the horizon of hope, that expand the field of the imagination ... and widen the field of informed, creative and critical citizenship' (Appadurai 2013, 215). OMG achieves this through sermons, teachings and testimonies that keep the hope and aspirations of member alive. Furthermore, the teachings given by financial coaches fall under the ethics of possibilities since they are part of informed and creative decisionmaking that draw members closers to good life. OMG provides members with navigational capacity to negotiate the unstable Zimbabwean crisis.

OMG has positioned itself strategically in dealing with precarity and uncertainties that are a result of ill-governance on the part of the state. OMG has strengthened the livelihood activities of its members in times of economic and political crises. Ethnographic insights discussed above show that Pentecostal movements are creative in their approach to deal with challenges that members face in their everyday lives. OMG initiatives are targeted on aspects of life that concern its members. Hart and Sharp (2015, viii) note that meaningful development can be realised when organisations focus their attention on what 'people are already doing' rather than impose their own approaches that often miss the desires of the people. By focusing on what people are concerned with and strengthening people's initiatives, as well as creating strong religious institutions such as housing cooperatives and entrepreneurial incubators, OMG become an effective vehicle for improving the lives of its members. Furthermore, $\mathrm{OMG}$ acts as a conduit that links puny members to corporates such as financial institutions, opening up opportunities that most Zimbabweans lack. Middle-range institutions are often ignored in most development processes, despite their effectiveness in linking broad entities such as state and corporates to ordinary citizens (Powers 2015).

As indicated earlier, OMG is composed of members from different socioeconomic categories, fostering social networks among its members who belong to different social classes. The cross-sectional composition of $O M G$ is a fertile ground for setting up business linkages and mentorship. Furthermore, professionals assist $\mathrm{OMG}$ to come up with pragmatic projects and initiatives for dealing with precarity and uncertainties that continue to threaten the livelihoods and well-being of the majority of Zimbabweans. OMG has gone beyond mere praying, $O M G$ has initiated pragmatic and realistic solutions to the challenges that threaten the livelihoods of its members. OMG is 'promoting 
economic democracy by helping people organize and improve their own lives' (Hart 2015, 4). This is achieved through producing new subjectivities and attitudes that promote shifts in ways things are done.

\section{Notes}

1 In this chapter I anonymise all names of persons and some of religious movements. The study focused on members of $\mathrm{OMG}$ and sought to understand ways in which the $\mathrm{OMG}$ shaped members' everyday lives in times of economic and political crisis. While I received consent from the religious movement, the study did not seek official position from the clergy, making it difficult to claim what I present in this chapter as the religious movement's position. Furthermore, a misunderstanding between Ilana van Wyk and Universal Church for the Kingdom of God informed my decision to anonymise the religious movement. (Mafokeng, 2015: https://mg.co.za/article/2015-10-30-letters-to-theeditor-october-30-to-november-5-2015.)

2 Sometimes called First Wave Pentecostalism.

3 This theology is based on the literal reading of Revelation 20 verses 4 to 7 .

4 The pseudonym for founder of $\mathrm{OMG}$ and the main prophet.

5 This statement is derived from the Bible and is the main scripture for 2018.

6 Bond notes were introduced as an export incentive. However, the bond notes have become a form of surrogate currency that is accepted as a legal tender in Zimbabwe only. Bond note is pegged at the same rate with the US\$.

7 Operation Restore Order or Operation Drive out Filth.

8 Literally Operation decent living.

9 The practice of having an extra-marital affair is popularly known as 'Small House Phenomenon'. See Mushinga (2015).

10 Tithe is a tenth and mandatory, free-will offering is a sign of one's faith in God and acknowledgement of that God is the source.

11 An international financial service provider.

12 I have provided the content pages of the booklet to give readers a sense of what is covered in the booklet and some of the planning tools suggested. The attached excerpt is from a book a respondent shared with me.

13 See Sabeta (2017) www.herald.co.zw/co-op-executives-jailed-3-years-for-fraud/. Samukange (2015) www.newsday.co.zw/2015/11/housing-co-op-leaders-accused-ofextortion/.

14 This figure was announced in September 2017 during a cooperatives' meeting in Harare. The financial statement of the cooperative circulated during the meeting also showed the same figures.

15 The decision by OMG members to purchase land is a wise one, another PCC in Zimbabwe obtained land under a government programme. In September 2016 the then president Robert Mugabe publicly attacked the minister of local government for corruptly allocating the PCC land to construct houses for its members. See Ncube (2016) www.newsday.co.zw/2016/09/mugabe-grills-kasukuwere-magaya/. Katunga (2016) www.sundaynews.co.zw/ban-of-housing-co-operatives-welcome/.

16 John 10, 10 (KJV), 'The thief cometh not, but to steal, and to kill, and to destroy: I am come that they might have life, and that they might have it more abundantly'.

17 Precast concrete wall that acts as parameter security in most premises in Zimbabwe. Most Zimbabweans find security in the precast concrete wall. In sermons, I have heard clergy at $\mathrm{OMG}$ making reference to durawall, for example during a sermon on 11 June 2018 a pastor made reference to the durawall as its solid protection. For a detailed discussion of this symbolism, see David Maxwell (2006).

18 Clifford Geertz (1973) argues that religion is part of cultural systems. 


\section{References}

Appadurai, Arjun. 2013. The Future as Cultural Fact: Essays on the Global Condition. London \& New York: Verso Books.

Asad, Talal. 1993. Genealogies of Religion; Discipline and Reasons of Power in Christianity and Islam. Baltimore, MD: John Hopkins University Press.

Ashford, Adam. 2005. Witchcraft, Violence and Democracy in South Africa. Chicago \& London: University of Chicago Press.

Berger, Peter. 2008. Under the Radar. Pentecostalism in South Africa and its Potential Social and Economic Role. Johannesburg: CDE in Depth 7. Johannesberg: Centre for Development and Enterprise.

Butler, Judith. 2004. Precarious Life: The Powers of Mourning and Violence. London: Verso Books.

Chirisa, Innocent, Marylin Gaza, and Elmond Bandauko. 2014. 'Housing Cooperatives and the Politics of Local Organization and Representation in Peri-Urban Harare, Zimbabwe.' African Studies Quarterly 15, no. 1: 37-53.

Chitando, Ezra. 2009. 'Deliverance and Sanctified Passports: Prophetic Activities amidst Uncertainity in Harare.' In Dealing with Uncertainty in Contemporary African Lives, edited by L. Haram and C. Bawa Yamba. Stockholm: Nordiska Afrikainstitutet.

Christerson, Brad, and Richard Flory. 2017. The Rise of Network Christianity: How Independent Leaders Are Changing The Religious Landscape. Oxford: Oxford University Press.

Clarke, William Norris. 1994. Explorations in Metaphysics: Being - God - Person. Notre Dame: University of Notre Dame.

Coleman, Simon. 2011. 'Prosperity Unbound? Debating the Sacrificial Economy.' Research in Economic Anthropology 31: 23-45.

Comaroff, Jean, and John Comaroff. 1997. Of Revelation and Revolution: The Dialectics of Modernity on a South African Frontier. Chicago: University of Chicago Press.

Comaroff, Jean, and John Comaroff. 2001. 'Millennial Capitalism: First Thought on a Second Coming.' In Millennial Capitalism and the Culture of Neo-Liberalism, edited by Jean Comaroff and John Comaroff. London: Duke University Press.

Ferguson, James. 1999. Expectations of Modernity: Myths and Meanings of Modernty and Urban Life on the Zambian Copperbelt. Berkeley. University of California Press.

Ferguson, James. 2006. Global Shadows. Africa in the Neoliberal World Order. Durham and London: Duke University Press.

Freeman, Dena. 2015. 'Pentecostalism and Economic Development in Sub-Saharan Africa.' In The Routledge Handbook of Religion and Global Development, edited by Emma Tomalin. Abingdon, Oxon: Routledge.

Geertz, Clifford. 1973. The Interpretation of Cultures. New York: Basic Books Inc.

Gifford, Paul. 1994. 'Some Recent Development in African Christianity.' African Affairs 93: 513-533.

Gifford, Paul. 2002. Christianity and Politics in Doe's Liberia. Vol. 2. Cambridge: Cambridge University Press.

Gifford, Paul. 2004. Ghana's New Christianity: Pentecostalism in a Globalizing African Economy. Bloomington \& Indianapolis: Indiana University Press.

Gifford, Paul. 2009. Christianity, Politics and Public Life in Kenya. London: Hurst \& Company.

Goebel, Allison. 2015. On Their Own: Women, Urbanization and the Right to the City in South Africa. Montreal-Kingstone: McGill-Queen's University Press.

Gono, Gideon. 2008a. First Quarter Monetary Policy Statement: A Focus on Food, Foreign Exchange Generation, Producer Viability and Increased Supply of Basic Commodities. Harare: Reserve Bank of Zimbabwe. 
Gono, Gideon. 2008b. Zimbabwe's Casino Economy: Extraordinary Measures for Extraordinary Challenges. Harare: ZPH Publishers.

Gukurume, Simbarashe. 2017. 'Singing Positivity: Prosperity Gospel in the Musical Discourse of Popular Youth Hip-Hop Gospel in Zimbabwe.' Muziki 12, no. 2: 36-54.

Hart, Keith. 2015. 'Introduction.' In Economy For and Against Democracy, edited by Keith Hart. New York \& Oxford: Berghahn Books.

Hart, Keith, and John Sharp. 2015. 'Introduction.' In People, Money and Power in the Economic Crisis: Perspective from the Global South, edited by Keith Hart, and John Sharp. Berghahn Books.

Haynes, Naomi. 2012. 'Pentecostalism and the Morality of Money: Prosperity, Inequality and Religious Sociality on the Zambian Copperbelt.' Journal of The Royal Anthropology Institute 18: 123-139.

James, Deborah. 2012. 'Money-Go-Round: Personal Economies of Wealth, Aspiration and Indebtedness' Africa: The Journal of the International African Institute 82, no. 1: $20-40$.

James, Deborah. 2015. Money from Nothing: Indebtedness and Aspiration in South Africa. California: Stanford University Press.

Jones, Jeremy L. 2010. 'Nothing Is Straight in Zimbabwe': The Rise of the Kukiya-Kiya Economy 2000-2008.' Journal of Southern African Studies 36, no. 2: 285-299. https:// doi.org/10.1080/03057070.2010.485784.

Kanyenze, Godfrey, Prosper Chitambara, and Judith Tyson. 2017. 'The Outlook for the Zimbabwean Economy.' Supporting Economic Transformation, London.

Katunga, Roberta. 2016. 'Ban of Housing Co-Operatives Welcome.' Sunday News, 21 February 2016.

Lessnoff, Michael. 1994. The Spirit of Capitalism and the Protestant Ethic: An Inquiry into the Weber Thesis. Cheltenham MA: Edward Elgar Publishers.

Mafokeng, Nametso. 2015. "'Hostile” Book on Church Is Inaccurate.' Mail E\& Guardian, 30 October, 2015.

Majengwa, Jeanette, Ibrahim Kasirye, and Collen Matema. 2012. 'Understanding Poverty in Zimbabwe: A Sample Survey in 16 District.' Economic Development in Africa.

Marshall, Ruth. 2009. Political Spiritualities: The Pentecostal Revolution in Nigeria. Chicago $\&$ London: University of Chicago Press.

Marshall-Fratani, Ruth. 2014. 'Christianity, Anthropology, Politics.' Current Anthropology 55, no. 9 .

Maxwell, David. 1998. 'Delivered from the Spirit of Poverty? Pentecostalism, Prosperity and Modernity in Zimbabwe.' Journal of Religion in Africa 28, no. 3: 350-371.

Maxwell, David. 1999. 'Historicizing Christian Independency: The Southern African Pentecostal Movement c. 1908-60.' The Journal of African History 40, no. 2: 243-264.

Maxwell, David. 2006. African Gifts of the Spirit: Pentecostalism and the Rise of Zimbabwean Transnational Religious Movement. Harare: Weaver Press.

Meyer, Birgit. 1998a. 'Commodities and the Power of Prayer: Pentecostalist Attitudes towards Consumption in Contemporary Ghana.' Development and Change 29: 751-776.

Meyer, Birgit. 1998b. "Make a Complete Break with the Past." Memory and PostColonial Modernity in Ghanaian Pentecostalist Discourse.' Journal of Religion in Africa 28: 316-349.

Meyer, Birgit. 2003. 'Material Mediations and Religious Practices of World-Making.' In Religion Across Media: From Early Antiquity to Late Modernity, edited by Knut Lundby. New York: Peter Lang. 
Meyer, Birgit. 2005. 'Mediating Tradition: Pentecostal Pastors, African Priests, and the Chiefs in Ghananian Popular Films.' In Christianity and Social Change in Africa: Essays in Honor of J.D.Y. Peel, edited by Toyin Falola. Durham: Carolina Academic Press.

Meyer, Birgit. 2007. 'Pentecostalism and Neo-Liberal Capitalism: Faith, Prosperity and Vision in African Pentecostal-Charismatic Churches.' Journal for the Study of Religion 20.

Meyer, Birgit. 2010. 'Pentecostalism and Globalization.' In Studying Global Pentecostalism: Theories and Methods, edited by Allan Anderson, Michael Bergunder, André Droogers, and Cornelis van der Laan. Berkeley: University of California Press.

Millar, Kathleen. 2017. 'Towards A Critical Politics of Precarity.' Sociology Compass 11: $1-11$.

Miller, Donald, and Tetsunao Yamamori. 2007. Global Pentecostalism: The New Face of Christian Social Engagement. Berkeley: University of California Press.

Mushinga, Mildred. 2015. 'The 'Small House': An Ethnographical Investigation into Economically Independent Women and Sexual Networks in Zimbabwe.' PhD diss., University of Pretoria.

Ncube, Xolisani. 2016. 'Mugabe Grills Kasukuwere over Magaya.' NewsDay, 8 September 2016.

Paradza, Partson, and Innocent Chirisa. 2017. 'Housing Cooperative Associations in Zimbabwe: A Case Study of Current Housing Consortium in Budiriro, Harare.' JOPPA 4, no. 2: 158-175.

Powers, Theodore. 2015. 'Negotiating State and Market: The South African HIV/AIDS Movement and Social Change.' In Economy For and Against Democracy, edited by Keith Hart. New York: Berghahn.

Robbins, Joel. 2004. 'The Globalization of Pentecostal and Charismatic Christianity.' Annual Review of Anthropology 33: 117-143.

Rotberg, Robert. 2002. 'The New Nature of Nation-State Failure.' Washington Quarterly 25, no. 3: 85-96.

Sabeta, Chipo. 2017. 'Co-Op Executives Jailed 3 Years for Fraud.' Herald, 26 September, 2017.

Samuelsson, Kurt. 1957. A Critique to Max Weber. New York: Harper Torchbooks.

Samukange, Tinotenda. 2015. 'Housing Co-Op Leaders Accused of Extortion.' NewsDay, 10 November, 2015.

Schlemmer, Lawrence. 2008. Dormant Capital: The Pentecostal Movement in South Africa and Its Potential Social and Economic Role. Johannesburg: CDE.

Schwartz, Shalom. 1994. 'Are There Universal Aspects of the Structure and Content of Human Values.' Journal of Social Issues 50: 19-45.

Scott, James C. 1998. Seeing Like a State: How Certain Schemes to Improve the Human Condition Have Failed. New Haven: Yale University Press.

Sorokin, Pitirim A. 1992. The Crisis of Our Time. Oxford: Oneworld Publications.

Stillman, Tyler T., D. Kathleen Voos, Nathanael M. Lambert, and Christa A. Phillips. 2012. 'The Material and Immaterial in Conflict. Spirituality Reduces Conspicuous Consumption.' Journal of Economic Psychology 33: 1-7.

Taru, Josiah, and Federico Settler. 2015. 'Patterns of Consumption and Materialism among Zimbabwean Christians: A Tale of Two Indigenous Churches.' Journal for the Study of Religion 28, no. 2: 113-137.

Tibaijuka, Anna. 2005. 'Report of the Fact-Finding Mission to Zimbabwe to Assess the Scope and Impact of Operation Murambatsvina.' Harare. 


\section{Josiah Taru}

Tsing, Anna Lowenhaupt. 2015. The Mushroom at the End of the World: On the Possibility of Life in Capitalist Ruins. Princeton: Princeton University Press.

United Nations Human Development Report. 2010. United Nations Development Programme. New York: UNDP.

Wacker, Grant. 2001. Heaven Below. Early Pentecostalism and American Culture. Cambridge: Harvard University Press.

Weber, Max. 1930. The Protestant Ethic and the Spirit of Capitalism. London: Allen and Unwin. 
Part VI

South African perspectives 
$\Longrightarrow$ Taylor \& Francis Taylor \& Francis Group http://taylorandfrancis.com 


\title{
20 Distinguished church leader essay \\ Cross-cultural development in South Africa - a perspective from below
}

\author{
Danie C. van Zyl
}

\section{Introduction: a personal history}

St Paul wrote: 'I know a man ...' (2 Corinthians 12:2). I know a man whose story of lifelong cross-cultural work I wish to share. This story may contribute some perspective on development, particularly in a cross-cultural environment. ${ }^{1}$

As a white Afrikaans-speaking South African, his cross-cultural experience started in the mid-1970s when he became the pastor of a Xhosa-speaking congregation in the Eastern Cape province of South Africa. It was at the high point of the apartheid regime when this part of the country had just become an independent Bantustan state, known as Transkei. He worked in a very remote part of the country on the so-called Wild Coast. It was, and still is, one of the most economically under-developed areas in South Africa. The community consisted largely of women, children and elderly men. The able-bodied men were working away in mines and as manual labourers in South Africa. Families survived on small-scale farming, mostly managed by the women, and financial support by family members working elsewhere.

The large majority of the population had no or very little education and could mostly speak only the local vernacular, called isiXhosa. Our friend therefore had to learn the language of the people in order to minister effectively. His advantage was that he could learn it by mixing with the local population in their daily life. This also introduced him on an intimate level with the lifeworld and the customs and traditions of the people. As part of his ministry he developed small-scale home industries and introduced a project to improve the local agricultural activities of families.

After further studies, he taught Biblical Studies at the University of the Western Cape to students from mixed cultural and confessional backgrounds. His postgraduate studies focused on the change of the meaning of Biblical texts when its context changes within the Bible. In fact, his final-year theology specialisation dealt with the question of contextualisation of the Eucharist in African culture. At that time in the seventies, questions on indigenisation and contextual theology were gaining momentum in missiological studies. Issues on African theology and liberation theology topped the agenda. These things shaped his interest in and commitment to cross-cultural hermeneutics.

For this reason, while teaching, he involved himself with faith communities in the black townships and squatter areas around Cape Town. He built friendly 
relations with church leaders of Xhosa-speaking churches across the full spectrum of Christian denominations. This was during the heyday of the liberation struggle in South Africa when the black townships were figuratively as well as literally speaking 'on fire'. The only white men to go to these areas were security police, the most targeted object of the struggle. Entering the townships, mostly by night, and moving about in this situation contributed to the level of mutual trust that developed between our friend and local church people. They cared for his safety and sometimes put themselves at risk, taking him to potentially dangerous situations. Attending day-long funerals, which are culturally very important events, and partaking in many all-night services, resulted in lifelong friendships with many local church leaders.

He had a long-time dream to be involved in developing Christian leadership in African churches, which are led by people who have no or very little training for their ministry. He, however, did not suggest this and waited for these leaders whom he had befriended to recognise the need for training themselves. This happened relatively soon when different persons suggested that he initiate a training programme. On this he moved around in the community and discussed the suggestion with a wide range of leaders. Those who were interested in such a programme were invited to meetings to discuss the matter. A number of senior leaders of mostly Zionist African Initiated Churches attended a series of Saturday meetings over a period of six months. At these meetings their views, wishes and fears were discussed until they reached consensus among themselves about what should be done and how it should be structured.

A launch committee was elected by them, which finalised a constitution and operational plan. From the beginning the committee took full ownership and was responsible for all decisions. They were involved in planning the curriculum; they decided that 'the Bible will be our only handbook'. The name of the school, Sokhanya Bible School, and its logo were their initiative. They were in full control of all finances and took decisions on the way money was raised and spent.

Teaching took place on a decentralised basis, as decided by the participants. Culturally sensitive adult education methods were used and allowed people to develop knowledge, personal and communication skills and improved the selfconfidence of even the most reserved persons in attendance. In this predominantly patriarchal society and churches, one of the most beautiful developments was the way in which women were accepted and given space, to the extent that women were on a number of occasions elected as chairpersons of the executive committee. Women clearly gained courage to take their place in the community and grew in confidence and gained respect.

Soon the work of the Sokhanya Bible School became known far and wide by word of mouth. People from areas who were not in a position to attend classes requested to receive the training material. Over the years the discussions in the weekly classes, in different groups and areas, were put in writing in the vernacular. These notes were then reworked into a correspondence course. At a certain point, learners from eight of the nine provinces of the country were doing 
the correspondence course. When the founder of the school was nearing retiring age, an intensive process of consultation involving all learners was initiated to decide on the future of the school. While it was clear that it could not continue as it had been running for more than 20 years, all were resolute that what had been achieved should not come to an end. The programme has since been taken over by another school and is continuing as a correspondence programme. There are, however, a number of people who completed the programme over the years, who continue to manage study groups in different parts of the country.

\section{Narratives of two church leaders}

By way of illustration, I quote two cases:

The first is a person who joined the school as a junior Zionist Church leader. He has no formal education and cannot read or write. When he first came, he had little insight in matters of faith and expressed peculiar opinions. He completed the three-year programme and then came back after some time. As he went through the programme a second time, it was noticeable how he was developing in insight and confidence. He continued for a number of years and kept on growing. Later he was able to explain complicated issues in a clear and meaningful way to fellow learners. He has since advanced to a senior position in his denomination. He is now a self-taught reader of the Bible and he can only read the Bible. He became a driving force in his area to continue with the activities of the school, even after it was formally discontinued. He is a wise leader who can take his stand among educated colleagues and in the wider community. He is a man of real integrity.

The second person was one of the first group of learners who joined the programme. At that stage he lived in a squatter area with his family and worked as a self-trained and self-employed builder. $\mathrm{He}$ is from one of the charismatic African Initiated Churches, which are generally very strict against sexual perversity. During the middle of the 1990s, the scourge of HIV/AIDS became prevalent in his and many other communities countrywide, and beyond. The general perception was that people who contracted the virus did so through loose sexual relations. For this reason, people who became known to be HIVpositive were frowned upon and most often condemned as sinners by many Christians and church leaders, and even the wider community.

A close relative of this person died of AIDS. This made him realise that the attitude of many Christians was wrong. He met with an old Zionist bishop, who also was one of his fellow learners and first chairperson of the Sokhanya executive, to discuss the issue. They decided they must take the initiative to help church leaders to gain new insight in the matter of HIV/AIDS and to realise that their attitude is un-Christian. They then started with an advocacy programme, visiting different churches. They then realised that they also have to attend to the needs of HIV-positive persons. First they visited local clinics where groups of HIV-positive persons met and offered prayers and counselling to them. 
Later they saw that their responsibility also lay in assisting the HIV-positive persons physically. Our charismatic friend and his wife began to prepare meals which they took to the clinics for HIV-positive persons to have a meal before they took their medication. He went around and established contacts and collected foodstuffs to prepare for these people. They started cooking meals at four in the morning on a single-burner gas stove. This was then taken to the clinics by public transport. Volunteer ladies from the community came to assist. This grew into a registered non-governmental organisation, which enabled them to access public funds. At a certain point this organisation employed about 40 persons from the community who did home-based care, visiting and caring for the terminally ill. Other community service projects followed. One of these is the management of a government job creation project through which 150 unemployed persons from the community gain an income. Another is a feeding programme which supplies 120 of the most desperate persons in the area with one meal per day, five days per week.

At present the organisation is managed by his daughter, who is a fully qualified social worker. She manages a very successful youth programme. Vulnerable youth are targeted, particularly those involved in crime, drugs and gangsterism. Many have experienced a change of life and continued with their education and became persons with a positive influence in their community. Youth development and social and moral reconstruction are crucial for the development of most societies, most of all for those who live in desperate physical and social conditions and who come from a history of disadvantagement and political struggle.

From this narrative I would like to highlight the following concerning the issue of development.

\section{Three levels of development: personal, community and economic}

First it seems to me that one has to distinguish three levels of development.

The first is personal development. This means creating opportunities for the unlocking of the inherent potential of individuals, in other words: their human capital. In the African context, and particularly in communities which most need development, this should be done in the community, not by individuals in isolation. Persons with a common interest or concern should have space where they can interact and grow together and develop as individuals and as a group. Key in this is that they themselves should identify the need and make the commitment to partake out of free will and from an inner conviction.

Second is community development, in the sense of growing the social and moral fibre of the community. For this level of development of human capital, persons from the community who have developed themselves and feel empowered and committed play a key role. This level of development is most desperately needed in communities where moral disintegration has led to widespread violence, substance abuse and other social evils. 
Third is economic development. This seeks to improve the living conditions and financial advancement of people, which lies on the level of material capital. This is the most obvious and of course a very urgent level of development needed in the lives of millions in Africa in particular. Current economic development favours only a small percentage of the population, while the gap between those who have and those who are left behind keeps on growing.

Economic development without the first two levels of development mentioned above is, however, futile and counterproductive. One example of the need for the second level of development to undergird economic development is the need for an effective school system, which is a serious concern in the current South-African situation. What is needed is a schooling system which will deliver not only knowledgeable individuals. Equally important is that the system should produce persons of character and with a sense of responsibility, not only for their own advancement, but for that of the community. Also civil society and faith communities have an even more important role in the restoration of community morality and unlocking the social capital of communities.

Economic development without persons of character and integrity is destined to fail. This is clear when one looks at what happens in small and large companies and institutions, and last but not least in governments. Levels of corruption and self-enrichment have reached unparalleled proportions in the recent past in South Africa in particular. The financial plundering of parastatal companies and the so-called 'state capture' is the result of individuals with no moral compass and who pay only lip service to the needs of the most disadvantaged. Corruption and disregard of law and order and for the needs of others has become endemic in society. This is an example that power, and therefore also economic power, corrupts. The saying goes: it takes strong legs to carry wealth.

Therefore, economic development and development aid which do not take the two more basic levels of development into account might not be worth the title 'development'.

\section{How should development be done?}

Second is then the question: how should this be done? From the foregoing narrative, a few suggestions:

Development aid will only be effective to the extent that it is built on identification with the 'recipient'. Any notion of paternalistic approach or attitude is fatal. From outside we may come with the best of intentions and denying any paternalistic motives. Suspicion is deep-seated in many African cultures, especially against outsiders. Their experience of colonialism, which is most often experienced as exploitation, has left unmistakable impressions on the psyche of Third World people. Furthermore, countless experiences of well-intended development aid which was not sustained or sustainable and has therefore failed makes people suspicious, for which they are not to be blamed.

Building trust between 'donor' and 'recipient' is essential but is a hard and long path to walk. This will ask not to look for quick 'results' on our inputs. 


\section{Danie C. van Zyl}

I have experienced that ordinary African people are very sensitive and keen judges of character. Trust should be mutual. This means that the 'recipient' must be respected as equally human, as persons with their own culture and value systems and wisdom. Trust is not ready-made: trust has to be developed, it must grow, it must be earned.

Buy-in by the 'recipient' party and acceptance of ownership is crucial for sustainable development. The 'recipient' should identify the need for what is to be done and have a desire to do something about it. It is therefore best to give aid where a project has already been initiated by the local community. Cultural and social sensitivity is needed in the negotiation of partnerships. To be trusted with control of finances and planning is vital for accepting and exercising ownership and is a major sign of trust. This goes hand in glove with accepting responsibility for operations, and for failures. Therefore development of management capacity may be needed which will ensure sustainability after the partnership has come to an end.

The question of who is to benefit is to be considered and managed very sensitively. All too often development aid has advantaged a small in-group, and Christian communities are not immune to this temptation. Someone recently said in my presence: 'When we see a white face, we see money.' In African culture it is bad manners to refuse an offer. The challenge is to develop sustainable and sustained partnerships in mutual trust.

There is a fundamental need for sustainability in development. Major development projects have failed once the partnership comes to an end and the external partner withdraws because a sound foundation has not been laid. Perhaps the issues raised here are not new, but the narrative context in which it was put here may serve to give a better feel of the nature and importance of these issues.

\section{Note}

1 This contribution does not purport to be of an academic nature. It is rather an African way of communication insight by way of story-telling. 


\title{
21 Contested development(s)? The possible contribution of the African Independent Churches in decolonising development
}

\author{
A South African perspective
}

\author{
Nadine Bowers-Du Toit
}

\section{Introduction}

Bompani $(2015,105)$ notes that despite the fact that African Independent Churches were often seen as not critical enough towards the then South African Apartheid state, 'more recent analyses highlight how AICs played a strong and supportive role among Black Africans in particularly deprived economic situations where there was often little support from mainstream development organisations'. It was, in fact, Evans, Bekker, Cross and Oosthuizen's 1992 study entitled 'Prophets for the poor: African Independent Churches' which was one of the first to outline the way in which the 'energies and activities of these churches could be linked to development initiatives' $(1992,33)$. More recently, Öhlmann et al. (2016) have highlighted the potential of African Independent and Pentecostal Churches as development actors for partnership with European development agencies.

Most of these authors highlight the potential of African Independent Churches as development actors for their more pragmatic contributions such as the development of social capital, their potential for small scale community upliftment projects and the promotion of moral values/ethics. My task in this contribution, however (although I will touch on these later in this chapter), is to conversely identify how the assumptions and practices, which undergird development itself, in conversation with African Independent Churches' grassroots praxis could unearth points of critique 'from below' to decolonise current western development praxis. The chapter, therefore, attempts to point out both the congruency and incongruity of the relationship between development and the Independent Churches in South Africa as well as to uncover their possible role in decolonising development as we know it within an African context. The latter implies a 're-centring' of development - a rejection that a western praxis of development should be the sole departure point in African development praxis. In the words of African scholar Achille Mbembe $(2015,18)$ 'decolonisation (a la Nugugi) is not about closing the door to European or other traditions. It is about defining clearly what the centre is'. In this sense the chapter is not an attempt to simply romanticise or fetishise the African Independent Church 


\section{Nadine Bowers-du Toit}

phenomenon, but rather an attempt to de-centre the notion that western development practices and assumptions - often undergirded by modernity should be uncritically applied as 'universalistic, neutral and objective' in its departure point (Grosfoguel 2007, 2011).

\section{AICs as promotors of African culture}

This section will outline some complexities around the term 'African Independent Churches' and highlight aspects which will be key to later analysis. Mbiti himself saw the rise of the African Independent Churches as 'an attempt for Africans to engage with African issues and context seriously' (Mbaya and Cezula 2016, 5). Masondo $(2014,11)$ highlights in particular the notion that these churches have played 'a key role as preservers, developers and promotors of African culture', and notes that 'these churches are a socio-cultural protest using precolonial African resources. They reject definitions of Christianity based on Western capitalist models'. Indeed, they have even been identified as providing cultural and symbolic responses to what he terms 'the brutal attack on Africans and their culture'. Prominent scholar of Black Theology, Simon Maimela's (in Masondo 2014, 3) explanation of an African understanding of salvation certainly assists in understanding AICs' theology and praxis:

The reluctance of Africans to break ties with the African Traditional Religions lies in the fact that they are wedded to an African worldview in which salvation is understood in terms of relief or help in times of trouble in this life. Salvation is thus expressed in such acts of healing, driving away evil spirits, empowerment of the individual self, the promotion of fertility, and success in life's ventures.

The latter denotes the African ontology - where the spiritual is intricately woven with the material - a holistic dimension which Mbaya and Cezula note also speaks to the communal nature of African life $(2016,7)$. The issue of time should also be understood as important to this world view and, therefore, to engagement with the African Independent Churches. Contrary to popular belief, Africans do have a concept of time, but it is understood in terms of an event other than a mathematically calculated period, wherein the past also distinctly defines the 'present reality and tomorrow' (Mbaya and Cezula 2016, 10).

\section{What's in a name? African Initiated or African Independent?}

This contribution focuses on African Independent Churches rather than African Initiated Christianity in its entirety. African Initiated Churches refers to a broader group which 'denotes all churches founded by Africans, in Africa and without direct links to missionary "godfathers"' (cf. Pobee and Ositelu 1998, 55). This definition then includes the Zionist, Ethiopian and Apostolic churches as well as the (mostly) independent Pentecostal-Charismatic 
Churches. ${ }^{1}$ African Independent Churches, on the other hand, are identified as a smaller sub-group consisting largely of the Zionist, Apostolic and Ethiopian groups and excluding the Pentecostal-Charismatic Churches.

Both groups certainly share some key 'markers' such as indigeneity and both indeed 'exemplify the African struggle for self-identification and self-realisation' (Masondo 2014, 3). In a strange way one could even argue that those Pentecostal and Charismatic indigenous churches who profess the prosperity gospel which is founded both on a promotion of health and wealth, but also on the empowerment of the individual self - are precisely drawn to this theology as a result of an African worldview. Black African students in my university classes over the years have certainly suggested this as counter to my critique of the prosperity gospel as 'preying on Africans'. Nevertheless, even though many of the largely independent Pentecostal/Charismatic sector may be Indigenous Churches, they are still deeply influenced by western notions of the prosperity gospel. The latter perhaps not so much then being a case of missionary godfathers - but perhaps more one of tele-evangelist stepfathers? In addition, many of these Pentecostal/Charismatic groups might even balk at the idea of being grouped with African Independent Churches as they may consider them 'beyond the pale': syncretic and perhaps not even as part of Christianity at all (cf. Kealotswe 2014, 239).

\section{Towards problematising development}

The notion of development as we understand it today is itself a contested one with many theories over the years seeking to provide theoretical frameworks to engage issues of poverty, marginalisation and inequality. Perhaps the most commonly held understanding of development remains that of the Modernisation Theory, a macroeconomic theory which upholds the supremacy of economics and the liner development of all majority world/global South societies from 'underdeveloped', third world societies to developed western societies. In this understanding development is unilineal and based on the assumption that 'west is best'. Local and indigenous knowledge is also regarded as less valuable than western knowledge systems and development and modernisation are conflated (Litonjua 2012, 27). Although this notion of development is no longer 'in vogue' within development circles, it still largely undergirds neo-liberal notions of development, which continue to permeate both development theory and practice today. McEwan $(2008,105)$ for example notes that 'despite persistent critiques the notion of development envisaged by modernisation has been reinvented in contemporary neoliberal discourses'.

Other theories such as Dependency Theory, Another Development, NEIO and Self-Reliant Development all followed with little traction, however, towards the 1980s the notion of People Centred Development was popularised by development scholars such as David Korten which saw a move from macroeconomic approaches towards a grassroots approach (cf. Bragg 1987, 28-38). In this more radical approach the locus of development is the local community 


\section{Nadine Bowers-du Toit}

and its people who are to participate in development. In the words of Korten $(1990,67)$ development is then defined as:

... a process by which the members of a society increase their potential and institutional capacities to mobilise and manage resources to produce sustainable and justly distributed improvements in their quality of life consistent with their own aspirations.

People were, therefore, to be empowered to participate in their own development and to manage and utilise local resources to their own benefit (Swanepoel and De Beer 2011, 38).

More recently Amartya Sen's Capabilities Approach has gained popularity in

seeing development as a process of expanding people's human capabilities.... In the field of development 'capabilities', according to Sen, do not refer to income, resources, goods, emotions or the satisfaction of preferences. It refers to what people are effectively able to do and be or the freedom 'to enjoy valuable beings and doings'.

(De Beer and Swanepoel 2011, 39; cf. Sen 1999)

In the past 15 or so years, development discourse has been popularly forefronted by the UN promoted Millennium Development Goals (2005-2015) and the more recent Sustainable Development Goals launched in 2016. These goals, as determined by the UN, are promoted as issue-based indicators of the development of respective nations, with the notion that should these be addressed, poverty, marginalisation and environmental degradation will be eliminated forever (cf. Sachs 2012).

While many of the later approaches to development appear to promote notions such as people-centred development, which are said to place the members of the community at the centre of their own development, many understandings of development are still undergirded by western notions of progress, secular and individualistic human rights and positivistic measurements (Mtata 2013, 31). The latter appears to suggest that there is a clear need for delinking the notion of development from the foundation of modernity on which the vast majority of current approaches to development rest (Mignolo 2007, 450). In this respect, scholars such as Mignolo (2007) and Grosfoguel (2011) have argued for critical border thinking, which takes 'seriously the epistemic perspective/cosmologies/insights of critical thinkers from the Global South thinking from and with subalternized racial/ethnic/spiritual/sexual spaces and bodies and which rejects the notion of the West being developed and the rest underdeveloped' Grosfoguel (2011). Wutich and Beresford (2015, 3) identify three development ideologies currently at play in their context of Latin America: neo-liberalism, ${ }^{3}$ alternative modernisation (which appears to renationalise industry, regulate trade and the influences of the West and promote indigenous ideology at state level) and decolonialism. They argue that while the alternative modernisation approach may address some of the critiques around 
neo-liberalism, it is not enough and should be augmented by decolonial approaches at grassroots level. These decolonial approaches, it is argued, are 'typically aligned with grassroots social movements, promote non-capitalist economies, collective forms of governance, deep ecology and indigenous worldviews' (Wutich and Beresford 2015, 5). Grosfoguel $(2009,32)$ goes as far as to suggest that 'development projects that focus on policy changes at the level of the nation-state are obsolete in today's world-economy and they lead to development illusions'. These 'development illusions' can only be confronted by recognising the power dynamics with regards to the flow of wealth from the North to the South and calling for global decolonial solutions.

The UN goals (Millennium Development Goals/Sustainable Development Goals), for example, while not wrong in and of themselves are once again a topdown list of global indicators imposed on national and then by design on local contexts - priorities set outside of context and often used by donors in determining funding priorities. Indigenous culture and knowledge systems are also often undervalued in development discourse and practice - which with its often western donor-driven agendas in conflict with local worldviews, issues and priorities has the danger of favouring what in development is termed an 'outside in' rather than an 'inside out' approach to development. According to August (2013, 79):

Development must be appropriate to the culture that is to be transformed. Nonetheless, modernizers have all too often ignored customs and social patterns in an attempt to bring material benefit to those who were regarded as 'backward.' They regard local tradition as an obstacle to change and technology without understanding the rationality of society's accumulated wisdom.

The results have been cultural imperialism and the destruction of indigenous values and even entire cultures. Particularly where donors and large-scale funding are involved, measurable outcomes are demanded as part of the accountability required - the meeting of which increasingly requires professionalised development staff with knowledge of logic frameworks and programme design and Monitoring and Evaluation (M\&E) skills. In some of the grassroots FBO's with which I work the employment of an individual with these skills is even demanded as a pre-requisite for funding by some donors. These power dynamics - often flowing from the global North to the global South - are increasingly being recognised by development thinkers. However, I would contest whether in much of development praxis 'the subalterns can truly speak' (Spivak 1994).

\section{Decolonising development? The possible contribution of the African Independent Churches}

This section explores key distinctives of development praxis and its underlying assumptions and brings it into conversation with the praxis of African Independent Churches. Grosfoguel $(2009,30)$ argues that a decolonial critique problematises the centring of western knowledge systems and power and argues that 


\section{Nadine Bowers-du Toit}

'subaltern identities could serve as an epistemic point of departure for a radical critique of Eurocentric paradigms and ways of thinking'. In this way, an attempt is made in this section towards some pointers in providing a de-centring critique to raise possibilities with regards to current development praxis by moving the locus of the analysis to African Independent Churches as subjects of this contribution.

\section{Restoring the unity of the body and spirit}

The very understanding of development is undergirded by enlightenment thinking and neoliberalism, which places the material and the 'will to power' at the centre of development and is often accused of emphasising 'economic and material wellbeing at the expense of other aspects of human life' (Tomalin 2013, 83). Development is still understood by many as materially focused and although the relevance of spirituality and religion has come into sharper focus in recent years, the alternatives to secular development strategies and critiques offered by religions to 'mainstream development goals' located within a western capitalist system have not been as deeply explored (Tomalin 2013, 83).

Indeed, African Independent Churches take seriously the spiritual world, recognised by Africans as part of daily reality - a reality often 'dismissed as superstition from a western perspective' (Öhlmann et al. 2016, 3). Well-being would, therefore, not be regarded as a purely physical phenomenon - as healing is regarded as holistic - so there is no division between the spiritual, psychological and physical and these interventions are therefore holistic in nature. Öhlmann et al. $(2016,5)$ note for example that healing is a focal point of many African Independent Churches' activities and that this if often seen as a 'process to support and encourage their members to overcome conditions in their lives perceived as a deficit'. Furthermore, their congregations were 'trying to respond to all the needs of their members and communities - spiritual, economic and social' and traditionally understood 'spiritual activities' are understood alongside development activities as development work. They note one church leader as saying that 'spiritual development is part of development' (Öhlmann et al. 2016, 5).

Mission Churches already largely acknowledge the same in recognising that development should address the whole person as well as the role of the spiritual and this has been recognised within the development sector as positive (cf. Myers 2011). Nevertheless, although systems of ethics and the value of particular teachings have been recognised by development scholars as possibly contributing to development, African Independent Churches in this way move the religion and development debate along still further by challenging the very roots of materialism itself as embedded in development. They do this in not only recognising the spiritual but placing as central what Christian anthropologist Hiebert (1982) calls 'the excluded middle' of the supernatural and its role in holistic healing. For African Independent Churches, development cannot truly be attained if there is no holistic healing - this begs the question: how will projects focused only on the material for example be regarded by them? 


\section{Re-centring African values and culture}

In postcolonial development discourse one of its core strategies is to destabilise the 'dominant development discourses of the West on the grounds that these are unconsciously ethnocentric ... and profoundly insensitive to the meanings, values and practices of other cultures' (McEwan 2008, 107). Kritzinger (1990), therefore, provides an interesting critique to early scholars seeking to study the relationship between new religious movements and development in noting that scholars such as Turner and Oosthuizen, while recognising the value of the African Independent Churches, still viewed development largely as 'westernisation'. It is precisely, however, indigenous notions of Ubuntu, healing and of salvation as noted by Maimela, that mark African Independent Churches unique contributions to development. ${ }^{4}$ Masondo $(2014,11)$, as aforementioned, even argues that they address issues of cultural injustice using precolonial resources.

Although Bompani $(2015,106)$, much like Turner and Oosthuizen before her, seems to suggest that 'AICs as an component of associational life among poor communities could shape a relationship with modernity and could therefore play a role within the "modernization" process', she identifies African Independent Churches' development ethos as distinct and unique. It is an ethos which sees local self-reliant development and strong networks of social support ultimately undergirding initiatives such as stokvels, burial societies and other networks which mitigate the risks of events which may produce socioeconomic vulnerability (cf. Öhlmann et al. 2016, 4; cf. Evans et al. 1992, 35). Western development agencies, therefore, seeking to engage these churches should and must not only take note of this tension or, as I believe Bompani does, view it in an instrumentalist manner. They should also seek to understand which aspects of African cosmology may directly work either against their understandings of development or possibly contribute towards enriching it. Projects suggested from outside for example should be aware of African cosmology - especially as it is located within the specific African culture it is seeking to work within.

\section{Promoting grassroots agency}

One of the hallmarks of development practice - despite a move by many scholars to encourage grassroots, participative processes which place the community at the centre of their own development - is the centrality of the development practitioner and professional practice. Even development as practiced by many grassroots NGOs in Southern Africa still sees an expert outsider to the community at the helm of many organisations and projects. In their early study, Evans et al. $(1992,37)$ note for example the very different 'drivers' of development practice between African Independent Churches and larger development agencies and NGOs:

Church members perceive the aims of development differently from the state development agencies and some larger non-governmental organisations 
(NGOs). While these larger bodies concentrate more in large scale development in terms of rational planning and service provision, the churches' range of development activities are influenced by the needs of their members, which are smaller-scale and embody more immediate requirements such as social and financial support.

African Independent Churches' development initiatives are largely small scale and locally driven - 'relying on the skills and qualifications of their members to engage in development activity' $(1992,37)$. Kritzinger $(1990,58)$ notes that much like the base communities in Latin America these churches promote a kind of koinonia which promotes development 'from below', rather than the kind of technocratic, professionalised development practiced by many agencies. In this practice the activities are - at least per people-centred development thinking and research - more likely to be sustainable in the long term as they are owned by the very people who benefit rather than by outside agencies and external development professionals (cf. Chambers 1997, 34-36).

The other aspect of professionalisation is that once again there is the possibility that a western outsider adds to the power dynamics already embedded in development and might I controversially add could become a new form of colonisation (cf. Chambers 1997, 59). One of the strengths of African Independent Churches according to Masondo $(2014,3)$ is that they 'exemplify the African struggle for self-identification and self-realisation' and 'provide an avenue for African self-definition by highlighting what is good about being African and inculcating a sense of pride in that identity'. In this way, they affirm an African understanding of personhood, which is a key component of self-actualisation which again explains why they require little outside intervention.

\section{Local priorities, agendas and support}

This aspect is linked to the previous point in some ways. African Independent Church projects are small scale, self-generated, resourced by local congregants and internally funded. This way of doing development is framed within an understanding that African Independent Churches serve as a home for their members - 'a closely-knit community for its members that acts as a powerful support structure during times of need' (Masondo 2014, 10). African Independent Churches are deeply connected to their own people at grassroots, with leaders noting that their focus was on local issues for this reason.

Issues highlighted by Evans et al.'s 1992 study and confirmed by Öhlmann et al.'s 2016 study is that as the development is largely locally driven by local volunteers there are often few or no 'individuals who can act as brokers with larger organisations to promote development interests' (Evans et al. 1992, 37). Of course, these findings also assume that outside organisations should be included to promote development interests! Larger scale donors, whether they be Northern donors or South African business and state actors require a high level of professionalisation for funds to be disbursed, which as aforementioned 
means that professionals should be well versed in project and programme management skills as well as Monitoring and Evaluation (M\&E). Öhlmann et al. $(2016,11)$ certainly allude to this in their highlighting the fact that 'administrative requirements' in interacting with donors should be kept to a minimum and that programmes be co-financed within their capacity. They still note, however, that although donors seek to be flexible in their requirements churches should be required to obtain qualifications in 'financial management, organisational development and monitoring and evaluation - where feasible even ex ante' $(2016,11)$. It should also be noted that programme and project management together with $M \& E$ are firmly based upon western notions of time and space - which are not (and should not) be understood as universal.

What is not noted in these papers is the pull of donor funding towards donor agendas, which are often driven by global priorities such as the SDG's rather than local realities. Several recent studies note the popular term 'social capital' and even 'spiritual capital' to identify the kind of development done by African Independent Churches and it is precisely, I think, because of the extensive social networks within these communities that these initiatives remain sustainable, as sustainability is not centered on financial capital. Indigenous concepts such as the isiXhosa ${ }^{5}$ word 'umfelandawonye' (which means 'dying together for a common purpose') or the Sotho 'Batho Pele', which means 'people first' calls particularly northern or western understandings of development to account. How will these donors respect the deep solidarity and locality of common purpose? How will they maintain that people, and not programmes and the money which they donate, will dictate the agenda?

\section{Conclusion}

While the critique of western notions of development and its inherent rootedness in the projects of modernity, colonialism and neo-liberalism is not new, in uncovering the congruencies and incongruencies between certain western notions of development and African Independent Churches I have sought not only to affirm the position that African Independent Churches do have an important role to play in development, but that this role extends beyond the pragmatic towards radical critique. African Independent Churches do more than serve development agendas - they are far more complex and operate from completely different assumptions to that of western development agendas as we know them.

In this regard, they have something important to say to western donors and organisations seeking to work on my continent and illustrate that subalternised subjects are capable of conceptualising their own realities. In fact, the article even argues from a decolonial perspective that African Independent Churches can serve as epistemic points of departure to critique and decentre western notions of development (Grosfoguel 2009, 12; 30). Although in many ways it may be argued that the African Independent Churches operate in line with 'people-centred' notions of development, their praxis nevertheless raises interesting questions, possibilities and challenges to particularly western organisations or large donors seeking to 
work with them. These include recentring African values and culture or restoring the body/spirit dichotomy. Furthermore, their praxis in fact fits in directly with decolonised notions of community development, which includes the promotion of non-capitalist economies, collective forms of governance and indigenous worldviews and, therefore, it may be argued that they are a rare example of what decolonised praxis could look like.

The praxis of these subalterns, therefore, speaks and such praxis often introduces yet more complexity to whether such donors and agencies will prove to be successful in engaging development truly 'from below'.

\section{Notes}

1 It should also be noted that while not all African Initiated Churches can be tarnished with the same brush, some of the independent Neo-Pentecostal Churches have recently been identified as conducting controversial healing practices such as encouraging their congregants to eat snakes, drink petrol and receive healing through the spraying of Doom (an insecticide).

2 In this sense Masondo (2014:3) notes that 'AICs provide an avenue for African selfdefinition by highlighting what is good about being African and inculcating a sense of pride in their identity'.

3 The approach commonly and previously referred to as Modernisation Theology.

4 Bompani (2010:309) notes that it is by taking African cosmology seriously that African Independent Churches have garnered such popularity.

5 An indigenous South African language and one of South Africa's 11 official languages.

\section{References}

August, Karlie. 2013. 'How Development Ethos Emerges and is Engrained and Sustained in Contact with Local Culture and Religion.' In Religion: Help or Hindrance to Development? Edited by Kenneth Mtata, 69-95. Geneva: Lutheran World Federation.

Bompani, Barbara. 2015. 'Religion and Development in Sub-Saharan Africa: An Overview.' In The Routledge Handbook of Religions and Global Development, edited by Emma Tomalin, 101-113. London: Routledge.

Bragg, W. G. 1987. 'From Development to Transformation' in The Church in Response to Human Need, edited by V. Samuel and C. Sugden, 20-51. Grand Rapids: Eerdmans.

Chambers, Robert. 1997. Whose Reality Counts? Putting the First Last. London: ITP.

Evans, Jeremy, Simon Bekker, Catherine Cross and Gerhardus Cornelis Oosthuizen. 1992. 'Prophets for the Poor: African Independent Churches.' Indicator SA 10, no. 1: 33-37.

Grosfoguel, Ramón. 2007. The Epistemic Decolonial Turn. Cultural Studies 21, no. 2/3: 211-223.

Grosfoguel, Ramon. 2009. A Decolonial Approach to Political-Economy: Transmodernity, Border Thinking and Global Coloniality. Kult 6 - Special Issue Epistemologies of Transformation: The Latin American Decolonial Option and its Ramifications. Fall 2009, 10-38. www.postkolonial.dk/artikler/kult_6/GROSFOGUEL.pdf

Grosfoguel, Ramon. 2011. Decolonizing Post-Colonial Studies and Paradigms of Political-Economy: Transmodernity, Decolonial Thinking, and Global Coloniality. TRANSMODERNITY: Journal of Peripheral Cultural Production of the Luso-Hispanic World, 1(1). 
Hiebert, Paul. 1982. 'The Flaw of the Excluded Middle.' Missiology: An International Review 10, no. 1: 35-47.

Kealotswe, Obed. 2014. 'The Nature and Character of the African Independent Churches (AICs) in the 21st Century: Their Theological and Social Agenda.' Studia Historiae Ecclesiasticae 40, no. 2: 227-242.

Korten, David. 1990. Getting to the 21st Century: Voluntary Action and the Global Agenda. Connecticut: Kumarian Press.

Kritzinger, Johannes J. 1990. 'African Indigenous Churches (AICs) and Development.' Skrif en Kerk 11, no. 1: 48-65.

Litonjua, M. D. 2012. 'Third World/Global South: From Modernization, to Dependency/ Liberation, to Postdevelopment.' Journal of Third World Studies 29, no. 1: 25-56.

Masondo, Sibusiso T. 2014. The African Indigenous Churches' Spiritual Resources for Democracy and Social Cohesion. Verbum et Ecclesia 35, no. 3: 1-15.

Mbaya, Henry and Ntozakhe Cezula. 2016. 'The Contribution of John S. Mbiti to the Study of African Religions and African Philosophy and Biblical Translation.' Paper presented at the conference 'Decolonizing African/Western Knowledge Systems Celebrating the Contribution of Prof. J. S. Mbiti,' Faculty of Theology, University of Stellenbosch, September 2016.

Mbembe, Achille. 2015. 'Decolonizing Knowledge and the Question of the Archive.' Wits Institute for Social and Economic Research (WISER), University of the Witwatersrand, Johannesburg.

McEwan, Cheryl. 2008. Postcolonialism and Development. London: Routledge.

Mignolo, Walter. 2007. Delinking. Cultural Studies. 21(2-3): 449-514. DOI:10.1080/ 09502380601162647

Mtata, Kenneth. 2013. 'Religion and Development: Friends or Foes?' In Religion: Help or Hindrance to Development? Edited by Kenneth Mtata, 23-36. Geneva: Lutheran World Federation.

Myers, Bryant L. 2011. Walking with the Poor: Principles and Practices of Transformational Development. New York: Orbis Books.

Öhlmann, Philipp, Marie-Luise Frost, and Wilhelm Gräb. 2016. 'African Initiated Churches' Potential as Development Actors.' HTS Theological Studies/Teologiese Studies 72, no. 4. http://dx.doi.org/10.4102/hts.v72i4.3825.

Pobee, John S. and Gabriel Ositelu. 1998. African Initiatives in Christianity: The Growth, Gifts and Diversities of Indigenous African Churches: A Challenge to the Ecumenical Movement. Geneva: WCC.

Sachs, Jeffrey. 2012. 'From Millenial Development Goals to Sustainable Development Goals.' Lancet 279: 2206-2211.

Sen, Armatya. 1999. Development as Freedom. Oxford: Oxford University Press.

Spivak, Gayatri Chakravorty. 1994. 'Can the Subaltern Speak?' In Colonial Discourse and Post-Colonial Theory: A Reader, edited by Patrick Willams, and Laura Chrisman. Hertfordshire: Harvest.

Swanepoel, Hennie, and Frik De Beer. 2011. Community Development: Breaking the Cycle of Poverty. Lansdowne: Juta.

Tomalin, Emma. 2013. Religions and Development. London: Routledge.

Wutich, Amber and Melissa Beresford. 2015. 'Community Development in Post-Neo Liberal Bolivia: Decolonisation or Alternative Modernisation?' Community Development Journal: 1-24. 


\section{Index}

Page numbers in bold denote tables, those in italics denote figures.

AACC (All Africa Conference of

Churches) 51

absolutism 92

Abundant Life 121

Abundant Life Faith Center 120

Accra Metropolitan Assemblies 200

activism, political 84-85; see also civic engagement

addiction programs 219-220

Addison, Kofi 221

Addo, Peggy 221

Adeboye, Enoch Adejare 43, 124, 140-141, 142, 144-145, 147

Adeboye, Folu 147

Adedibu 25n4

Adejobi, E.A. 231

Adeyemi, Sam 120

Adogame, Afe 82-83, 88, 92n2

Africa: environmental crisis in 51-54; independence in 197; modernisation of 41-42; myth of development in 196-200; Pentecostal revolution in 269-271; poverty in 115; religious innovation and development in 35-43; underdevelopment in 115; youth crisis in 270; see also Botswana; Burkina Faso; Ethiopia; Gambia, the; Ghana; Gold Coast; Guinea Conakry; Ivory Coast; Kenya; Nigeria; South Africa; West Africa

African Christianity: government support for local churches 109; removing lines of segregation in 108 ; renewal movements in 62; traditional understanding of salvation in 63

African Churches 5, 6; see also African Independent Churches; African
Indigenous Churches; African Initiated Churches; African Pentecostal Churches African Convention on Nature and Natural Resources 54

African Divine Church in Kenya 14

African Enterprise 190

African Forum on Religion and Government 190

African Independent Churches 3, 5, 20, 33, 35-37, 73, 233; in Burkina Faso 255; as communities 79; decline of 35-36; and the decolonisation of development 311-320, 315-316; as development actors 311; development initiatives 317-320; as ecological preservationists 42; and the Good News Theological Seminary 236-238; histories and biographies of leaders 235; negative perceptions of 230; and political nationalism 41; as promoters of African culture 312; relationship with Mission Churches 23, 227-238; on religion and development 34-35; role of women in Nigeria 105-114; sustainable development programmes 236; terminology 312-313; see also Independent Churches

African Indigenous Churches 5; see also Indigenous Churches

African Initiated Christianity 1-25, 36, $49,105,164,167$

African Initiated Churches (AIC) 4-5, 24; addressing environmental challenges 53; African Independent Churches as 90; African PentecostalCharismatic Churches as 90; and African solutions 12-13; as agents of 
social change 14-15; and the decolonisation of development 24-25; demographic significance of 10-11, 11; and development 11-12, 33-49, 38-39, 73; and development from below 16-17, 20, 90-92; and development in Africa 41-42; dress codes in 96; ecological awareness in 66-67; emergence of 183; empowerment and agency of 13-14; first generation 6; in Ghana 234; as grassroots movements 96; independence of $12-13,16$; as people's organisations 79; political involvement of $12,15,17$, 20, 83, 89-90; potentials and perspectives with regard to sustainable development 8-18; promotion of entrepreneurship by 14; and the Protestant work ethic 13-14; role of women in 20-21; second generation/ wave 6,167 ; social transformation activities 164-165; styles of worship in 95; terminology 312-313; and sustainable development 3-4; theological training in 97; theology of $20,35,95-100$; third generation 6-7; three waves of $6-7,7$; and traditional African values 20

African Instituted Churches 33

African International Churches 5

African Methodist Episcopal Church 64

African Pentecostal-Charismatic Churches 5, 6-7, 74, 86; characteristics of 7-8; promotion of entrepreneurship by 14; theology of 6-7; see also African Pentecostal Churches; Pentecostal Charismatic Churches

African Pentecostal Churches 3, 5, 14, 17, 20, 22, 119, 143; challenges of promoting sustainable development 130-132; classical vs. Neo-Pentecostal 119-120; gender equality in 20-21; indigenous vs. foreign 119; NeoPentecostal 120; origin and initial focus 119-121; precursors response to poverty and underdevelopment 115-133; as response to mission Christianity 119; spiritual capital of 121; see also African Pentecostal-Charismatic Churches; Pentecostal Churches

African Reformation 4

African Renaissance 73

African traditional religions 6, 8 African Union (AU) 54; Agenda 2063 56-57
Africa Sustainable Development Report 56 Afrocentrism 45

AGAPE (Alternative Globalization Addressing People and Earth) process 56

Agape Family Care 279

agape meal 95

agency: grassroots 317-318; of the individual 13; and spiritual security 295-296

Agenda 2030 for Sustainable Development 2, 8-9, 196, 261

Agenda 2063 56-57

Aginasare Foundation 216

Agyemfra, L.S.G. 229

Agyinasare (Agyn-Asare) Charles 205, 215-216, 223

Akindayomi, Josiah Olufemi 124, 140-141

Akrofi-Christaller Institute of Theology, Mission and Culture 237

Akufo-Addo, Nana 205

Akurinu Churches 6, 95

Aladura Churches 5, 6, 8, 22, 25n3, 33, $41,151,231$; as agents of social transformation 164-173; challenge of insufficient funds 171-172; challenge of personnel shortage 172; challenges and prospects 171-172; educational services 168-170; health services 170; political activities 170-171; in South-West Nigeria 167-168; as spiritual churches 168-169; theology of 175-179

All African Conference of Churches (AACC) 51

Alternative Modernisation 314

Ambode, Akinwunmi 146

American churches, as models for African Pentecostal Churches 105, 153

American Faith Gospel 205

Amoah, James 235

Amu, Ephraim 234

Anderson, Allan 4, 184

Andoh, Robert 221

Anglican Church 38, 64, 167, 213, 234

Anglican Church of Ghana 221

Anim, Peter Newman 184, 205

Another Development 313

Anquandah, James R. 228, 235

anthropocentrism 52

Apostles' Creed 177

Apostles Revelation Society (ARS) 39, 229, 237

Apostolic Churches 5, 6, 35, 74, 119, 185-186, 236, 312-313 
Apostolic Church of the UK 184, 186

Appiah, Jehu 230

Aquaye, Mike 221

Aroti Churches 95; see also Akurinu

Churches

ARS (Apostles Revelation Society) 39, 229,237

arts, culture, and entertainment 129

Asamoah-Gyadu, Kwabena 229

Asante, David 116

Asante-Antwi, Rev. Dr 235

asceticism 87

Ashimolowo, Matthew 45, 46-47

Assemblies of God Church 23, 35, 119, 236, 243, 244-246, 252, 255

Association Evangélique d'Appui au Développement (AEAD) 243, 246-247, 248

Association of African Earth-keeping Churches 65

Association of Zimbabwean Traditionalist

Ecologists 65

authoritarianism 197

Ayete-Nyampong, Lilian 257

Azusa Street revival 184, 203

Babalola, Joseph Ayo 120, 168

Baëta, C.G. 227, 233, 235

Baidoe, John Kojoe 227

Bakare, Tunde 131

Ban Ki-Moon 142

baptism 95, 117, 186, 288-289

Baptist Church 38, 167, 234, 235

Barrett, David 203-204, 269

Basel Missions 116-117, 118

Bawumia, Mahamudu 205

Beckmann, Davvid 228

Bediako, Kwame 207

Belgian Congo 41

Benin 257

Berger, Peter 285

Bethel Bible School 203

Bible: and the Apostolic Churches 185-186; translations of 165

Bible League 190

Bible school concept 187-188

Bible Society of Ghana 190

Bible Society of Nigeria 114

Billionaires Mindset Summit 274

Bismark, Tudor 120

blessings of Abraham 153

Bompani, Barbara 79, 82-85, 88-89, 91, $171,257,311,317$

Bonkoungou, Odile 249
Bophelong Bible Church 18

Botswana 271

Bragg, Wayne 253

Braide, Garrick Sokari 119

bribery 201-202

bridge-building 143

British Department for International Development 1, 250

Brundtland Report 212-213

Bujo, Benezet 60

burial societies 89

Burkina Faso: African Independent Churches in 255; Centre International d'Evangélisation/Mission Interiéure Africaine 253-262; empowerment of women in 23; partnerships for female education 243-252

Busia, Kofi 197

Busia, Kofi Abrefa 197, 209

business initiatives 129; see also entrepreneurism

CAC (Christ Apostolic Church) 119, 120-121, 167

CADAM (Campaign Against Drug Abuse Ministry) 146-147

CAIC (Council of African Instituted Churches) 85

Calvinism 285, 290

Campaign Against Drug Abuse Ministry (CADAM) 146-147

Campbell, Andrew 196

Campus Holy Ghost Service (CHGS) 144-145

campus secret cults (CSCs) 144

CAN (Christian Association of Nigeria) 157, 167

Capabilities Approach 314

capitalism 271; consumer 152; global 275; neoliberal 87, 284; penny 278; western 312

carbon-fasting 64-65

Catholic Church 4, 38, 213; Charismatic 120, 140; in Ghana 234; Justice Development and Peace Commission 166-167; see also Christianity; Roman Catholic Church

CCC (Celestial Church of Christ) 167-168

CCN (Christian Council of Nigeria) 179

Cecil, Murphey 220

Celestial Church of Christ (CCC) 167-168 
Centre International d'Evangélisation/ Mission Interiéure Africaine (CIE/ MIA) 23, 254; department of media and publications 261; educational and development projects of 256-257; holistic mission and development/ transformational development 256-261; mission statement 255-256; prison ministry 258-259; and the role of women 259-260; and transformational development 253-262

Chand, Sam 220

Chapel of Resurrection 167

Charismatic Churches 45, 120, 140, 203; in Ghana 214; see also African Pentecostal-Charismatic Churches; Pentecostal Charismatic Christianity: Pentecostal Charismatic Churches charismatic fellowships, transdenominational 120

charismatic leaders 35, 37; women as 114 charismatic renewal 36

charitable activities 141-142

Cherubim and Seraphim Church $(C \& S)$ 124, 140, 167, 168; and Moses Orimolade University 169

CHGS (Campus Holy Ghost Service) 144-145

chieftaincy institution 191

childbearing 157

Child Evangelism Fellowship 190

children and youth ministry 259

Child's Right International 220

chimurenga 65

Christ (Jesus): belief in 110-112; as ecological ancestor 60-61; as focal point 253; as 'Lamb of God' 177-178; mandate of 123; mission of 62

Christ Apostolic Church (CAC) 119, 120-121, 167

Christ Embassy International 120

Christian Action Faith Ministries 205

Christian Association of Nigeria (CAN) 157, 167

Christian Care 119

Christian Council of Ghana 39, 190, 229-230, 233, 234

Christian Council of Nigeria (CCN) 179

Christianity: in Africa 46, 203-204; African 53, 57, 139-140, 237; African leaders for 46; conversion to $116-117$, 118; and development 37, 250; ecological reformation of 57-63; enchanted 139-140; and the environmental crisis in Africa 51-54; eschatological importance of 38 ; as nonwestern enterprise 37; as non-western religion 43; non-western re-thinking of 20; and the plan of redemption 63; and religious innovation in Africa 35-43; see also Catholic Church; Protestantism; Roman Catholic Church

Christian Political Leadership 158

Christian Rural Development Association of Nigeria 131

Christiansborg Castle 229

Christian Service College 235

Christian Social Responsibility (CSR) 21, 116, 125-130; arts, culture, and entertainment initiatives 129; business and economic initiatives 129; education initiatives 128; governance and political initiatives 129; health initiatives 128; media initiatives 129; social initiatives 127-128; sports initiatives 129-130

Christ Redeemer College 147

Christ Redeemers School Movement (CRSM) 147

Christ Way Church (CWC) 151, 160

Christ Way Ministries International 151, 154, 156

churches: growth through theology and development 112-113; indigenous 313; Mission Initiated 8

Church Missionary Society (CMS) 116, 165

Church of Bethel 234

Church of God Missions International 120,154

Church of Melchizedek 234, 235

Church of Pentecost (CoP) 15, 16, 22, 35, 119, 120; doctrine and practices 185-186; emergence of 184-185; fellowships/fraternities/para-church organisations 190; finance 188; in Ghanaian society 183-193; public roles 190-191; social needs in the external branches 191-192; social services 188-190; spread of 184-185; structure and government 186-187; training for 187-188; worship 187; see also Pentecostal Churches; Pentecostalism Church of the Lord (Aladura) 168, 231

Church of the Lord (Aladura) Worldwide 8

Church of the Lord (Brotherhood) 234

Church of the Lord (Ghana) 234 
Church of the Lord (Prayer Fellowship) Worldwide see The Church of the Lord (Prayer Fellowship) Worldwide (TCLPFW)

Church of the Messiah 234

CIE/MIA see Centre International d'Evangélisation/Mission Interiéure Africaine (CIE/MIA)

citizenship, and social engagement 47-48

City of David (RCCG parish) 127

City of David Business Networks 129

civic engagement 15, 21, 22, 47-48, 157-160, 190-191, 267; and the Redeemed Christian Church of God 141-142; see also political activism cleansing 95

climate change 61

climate justice/injustice 54-55, 63-68

clinics, church-sponsored 213, 214; see also healthcare delivery

colonialism 81, 138, 319

commensalism 161

communalism 20

Compaoré, Sabine 246-247

complementarities 161

Congo 119

Conradie, Ernst 253

consumer capitalism 152

contextuality $7,10,12,13,16,17,19-20$, 23, 24-25

Coptic Church 62

corporate donors 130

corporate social responsibility (CSR) 125

corruption 201-202

cosmology, African 317, 320n4

Côte d'Ivoire 256-257

Council of African Instituted Churches (CAIC) 85

covenant paradigm 44

Cox, Harvey 42

critical border thinking 314

cronyism 201

CSCs (campus secret cults) 144

culture: African 317, 320; indigenous 315; see also Yoruba culture

cura divina (divine healing) 165; see also

healing ministry

CWC (Christ Way Church) 151, 160

dance, in Pentecostal churches 105

Daneel, Inus 42

Daneel, Marthinus L. 62, 65

Daniels, David 206

Daramola, Elijah 15, 18
Daughters of Abraham Fellowship 108

Daystar Christian Centre 120

De Almeida, Teddy 274

Deborah (prophetess) 106, 107

decentralization 16

decolonial debate 2

Decolonialism 314-315

decolonisation: of development 2, 16-18, 21, 23, 24-25, 311-320, 315-316; by

Pentecostals 21

deep ecology 315

Deeper Christian Life Bible Church 156

Deeper Christian Life Ministries 154

Deeper Life Bible Church 119, 120

demonic practices 156-157

demons, casting out 95, 125

Department for International

Development 137

Dependency Theory 313

development: in Africa (myth of)

196-200; alternative 78; autonomous

78; bottom-up 22; challenges of in

Nigeria 171-173; Christian 253-254;

church growth through 112-113;

community 145, 267, 278, 308-309;

cooperation in 24; cross-cultural

305-310; decolonial concept of 20;

decolonisation of 2, 16-18, 21, 23,

24-25, 311-320, 315-316; discourses of 1-2; ecological 9-10; economic 9-10, 78, 81, 118-119, 136, 199-200, 285, 309; educational approaches to 147 ; failures of 78; goals of 316; grassroots 20, 24, 78, 81, 131, 313-314, 317-318; hermeneutics of 45-47; holistic 3, 123, 132, 212-213, 218-223; holistic youth 218-219; human 34-35, 38, 43, 145; of human character 123; human resource 213; integral 3; international 24; issue of faith in 250; as liberation process 137; locally driven 318-319; means of accomplishing 309-310; and modernity 285, 314; outside in vs. inside out 315 ; participatory 78 ; as part of religion 2 ; and the Pentecostal Church in Nigeria 151-162; Pentecostalism and 213; people centered 78, 313, 319; people's self-development 78; personal 267, 308; physical 18, 42, 43; political 10; popular 78; problematising 313-315; and prosperity gospel 272-274; 'recentring' of 10-11; in the Redeemed Christian Church of God (RCCG) 136-148; and religion 1, 34-35, 136-140, 147-148, 
271-272, 285; religious dimensions of 17-18; role of the church 267; secular (western) concepts of 18 ; self-reliant 313; social 9-10, 18, 43, 49; societal 42-43; socioeconomic 16, 38, 214, 276; spiritual 18; state-driven 24; state failure of 78, 80-82; transformational 3, 23, 253-262; values-based 195-196; western definition of 138; as 'westernisation,' 317; western practices of 312; Yoruba thought on 123; see also development from below; selfdevelopment; sustainable development development from below 16-17, 20; in African Initiated Churches 73-92; and African Initiated Churches 90-92; as capacity to generate social capital 87-90; as counterpoint to development from above 20, 80-82, 90; as desecularised catchphrase or idea 20, $75,78-80,90$; literature capturing the thesis of 76-77; personal economic empowerment 20; and personal transformation 85-87, 90, 91; political dimension of 82; as political dynamic $82-85,90,91$; and the political role of AICs 20; and social capital 20, 90, 91; as social change from below $85-87$

development studies 1, 75

development theory: mainstream (western) 79; 'religious turn' in 1

Divine Encounter 144 divine healing (cura divina) 165, 168-169, 186; see also healing ministry

Divine Healing Church of Christ 234

Divine Salvation Bible Church 106, 112 divorce 156-157

dominium terrae tradition 53,58 dreams 95, 96

dress codes 96; see also white garments drug addiction 219-220; ministry addressing 146-147; see also substance abuse

Duncan-Williams, Nicholas 205

Dupret, Pierre 245

Dutch Reformed Church 25n1

Earthkeeping Spirit 42

East Africa 6; agriculture in 12

Eastern Nigeria Christian Council 231

eco-justice 56

ecological debt 56

ecology, and the church 22

economic crises 284 economic initiatives 13, 129

economic injustice 54-55

Economic Recovery Programme (ERP) 198

economics 1; and Modernisation Theory 313; neoclassical 75, 78

Economic Structural Adjustment Programme (ESAP) 287

economy: and the church 22; informal 289; moral 294-295

eco-spiritualities 63

eco-theologies 51-68; African 20; in

African Pentecostalism 63

Eden Revival Church 228, 234

Ede University 142

Edo, Victor 147

education: and the Aladura Churches 168-170; and the church 21-22, 22; and development 216-217, 220; as development goal 14; informal 165; initiatives for 128 ; Islamic 165 ; and mission 256; opportunities for women 109; partnerships for female education 243-252; Pentecostalism and 154, 214-215; and Perez Chapel

International 216-217; for poor students 278-279; and sustainable development 213, 217, 256; theological 98-99; for women and girls 243-252; see also schools

Education Orientation Law 248-249

ELCA (Evangelical Lutheran Church in America) 235

Ellis, Kwesi, B. 235

employment opportunities 156

empowerment 16; of believers 33-34;

black 45-47; hermeneutics of 46; of the individual 313; of individuals 169, 262; physical 37; programmes for 141-142; self-, 84 ; spiritual 37; of women 23, 306; of youth 24,271

endowed professorial chairs 128

enlightenment 81

enlightenment cultures 52

entrepreneurship 87, 267, 285-286; and

Pentecostal Charismatic Christianity

(PCC) 290-293; promotion of 14

entrepreneurship workshops 12, 14,

274-278; youth empowerment 12

environmental degradation 51, 52, 54-55,

$66,208,212$

environmental initiatives 132

environmental justice 122

Episcopal Church 114 
Eritrean Oriental Orthodox Church 62

ERP (Economic Recovery Programme) 198

ESAP (Economic Structural Adjustment

Programme) 287

essentialism 92

ethics 42-43

ethics of possibilities 297

Ethiopia 46

Ethiopian Churches 6, 25n2, 62, 74, 312-313

ethnography: in Pentecostal Churches 284-298; in Zimbabwean PCCs 268-269

eucharist 95; earth-healing 65-67; see also Lord's Supper

Eurocentrism 16

Evangelical Christians see Pentecostal Churches

Evangelical Churches 131, 252; supporting female education 243-252; see also Pentecostal Churches

Evangelical Church of Divine Salvation Bible Church 112

Evangelical Lutheran Church in America (ELCA) 235

Evangelical Presbyterian Church 39, 213, 233, 235, 236

evangelism 120, 261; linked to social welfare programs 132

Excel Charity Foundation 127, 130

Excel City of David Cooperative Society 129

excellence model 45

exorcism 167, 230

faith-based organisations (FBOs) 315; Christian 252; and female education 246-247; myths about 250-251; in Pentecostal Churches 271; supporting female education 243-252

Faith Brotherhood Praying Circle 234

Faith Gospel 121

faith healings 155, 167; see also healing ministry

Faith Tabernacle Church 184, 205

Family Health International 146

Family of God Church 120

Fast for the Climate Movement 64-65

fasting 40, 64-65, 165, 179, 230

FBOs see faith-based organisations (FBOs)

Fédération des Eglises et Missions Evangéliques (FEME) du Burkina Faso (Federation of Evangelical Churches and Missions in Burkina Faso) 255, 261
Fellowship of Christian Ministers Nigeria 113-114

fellowships 108

feminism 62

Femmes de Destiné (Women of Destiny) 260-261

financial literacy 292

football clubs 129

Forbes, James 206

Foster, G. M. 199

founding visions 99-100

Fourah Bay College 116

Foursquare Gospel Church 119

Frahm-Arp, Maria 83

Francis (pope) 59-60

Freeman, Dena 85-87

fundamentalism 192

funding sources: challenge of insufficient funds 171-172; corporate donors 130; and donor agendas 319; partnership initiatives 131; for Pentecostal Churches 152

funerals 192

Gambia, the 48; Methodist Church in 116

garbage theology 67

garments, for worship 37, 96

Garner, Robert 42

gender equality/inequality 20-21, 106

Gerloff, Roswith 185

German Federal Ministry of Economic Cooperation and Development 1

Ghana 15, 33, 35, 38, 39, 41, 45, 119; African Independent Churches in 227-228; Charismatic Churches in 43; Christianity in 223; church schools in 117; in context 201-202; Good News Theological Seminary 227-238; military coups and dictatorship 200; mission schools in 118; Neo-Pentecostal Charismatic Churches in 120; neopotism, bribery and corruption in 201-202; Pentecostal Churches as agents of sustainable development 195-209; Pentecostalism and sustainable development (Perez Chapel International) 212-223; postcolonial developments 197-200; role of the Church of Pentecost in Ghanaian society 183-193; see also Church of Pentecost (CoP; Ghana); Perez Chapel International

Ghana AIDS Commission 190, 208, 220 
Ghana Apostolic Church 184; see also Church of Pentecost

Ghana Evangelism Committee (GEC) 190

Ghana Institute of Linguistics, Literacy and Bible Translation 190

Ghana National Peace Council 190

Ghana Pentecostal and Charismatic Council (GPCC) 190

Ghana Prisons Service Chaplaincy Unit 190

Giddings, Bob 122

Gideon International 190

Gifford, Paul 37, 45, 213

Gilgal Bible Church 8

Global Evangelical Church 236

Global HIV/AIDS (GHAIN) initiative 146

globalisation: cultural 269; and religion 164

Global Revival Ministries 221

glossolalia (speaking in tongues) 95, 110, 179,270

God's Children Great Talent 129

Gold Coast 119; Basel Mission in 118; church schools in 116, 117

Golo, Willie Kwaku 63

good life 3, 296-297

Good News Bible Classes 231, 233; see also Good News Theological Seminary

Good News Church 274

Good News Theological Seminary 23, 227-238; wound-healing ministry of 236-238

Good News Training Institute 234, 235

gospel of prosperity 152-156

Grace Bible Church 120

Graham, Billy 110

Greek Orthodox Academy of Volos 57

'green church' networks 63-64

greenhouse gases 67

Group Esther 260

Grove, Erma 234-235

Guinea Conakry 257

Gyadu, Kwabena Asamoah 183

Harris, William Wade 41, 119, 227

HDI (Human Development Index) 81

HDRs (human development reports) 140

healing 40, 41; importance of 74

healing ministry $124,155,165,167,230$, 316; of Benson Idahosa 121; of Christ Apostolic Church 120-121; controversial 320n1; see also faith healings
Healing Stripes Diagnostic Centre and Pharmacy 128

health and wealth gospel 272; see also prosperity gospel

healthcare, and the church 21-22

healthcare delivery 128, 141, 145-146, 156, 165, 258; and the Aladura Churches 168-170; church-sponsored clinics 213, 214; in Ghana 202; holistic 146

hermeneutics: of black empowerment and development 19-20, 45-47; ecological 58-59

HIV/AIDS awareness 12, 145-146, 258, 307-308

holiness doctrine 154

Holy Church of the Lord (Ghana) 233

Holy Ghost Congress 143, 144

Holy Ghost Services 144

Holy Spirit: advice and presence of 96; belief in 74; experience of 33; gifts of $96,186,269-270$; indwelling of in creation 62 ; inspiration from 95 ; intervention of 38 ; ministry of 35 ; mission of 62; power of $13,45-46$; presence of 37; and Progressive Pentecostals 43; role of 6-7, 186; as 'vital force' in nature 61 ; work of in the whole of the universe 62; see also speaking in tongues

Holy Spirit Church of East Africa (HSCEA) 100

hope, politics of 296-298

hospitals, church-sponsored 12, 17, 43, 128, 156

Hospital Visitation Committee 170

housing cooperatives 294-295

housing provision 294-295

Human Development Index (HDI) 81

human development reports (HDRs) 140

human flourishing 3

human resource development 213

human rights 314

hybridisation 6

Ibrahim, Yussif 221

ICGC (International Central Gospel Church) 15, 43, 120

Idahosa, Benson 120, 121, 154

Idahosa, Margaret 108

Ilosiwmu/Omoluabi 17

Iluyomade, Idowu 125-126

imago Dei 237 
IMF (International Monetary Fund) 81, 118, 137, 198-199

Impact TV 261

imperialism 138; cultural 315

independence movements 5-6

Independent Churches 5, 6, 48-49, 62; theological education in 23; see also African Independent Churches

indigenisation 6, 16

Indigenous Churches 6; see also African Indigenous Churches

informal economy 289

Information and Communication Technology (ICT) Centre 236

infrastructure finance 12 ; sources for funding 130

Innocent, Pastor 267

insecurity, spiritual 295-296

International Central Gospel Church (ICGC) 15, 43, 120

International Monetary Fund (IMF) 81, 118, 137, 198-199

International Partnership on Religion and Sustainable Development 1

Islam 109-110; see also Muslims

isolation 92

Ivory Coast 48

Jabula New Life Covenant Church 120

Jakes, T.D. 45

James, Deborah 291

James, Prophet 275

Jenkins, Philip 260

John (the apostle) 152

Joseph Ayo Babalola University 169

Justice Development and Peace

Commission (JDPC) 158, 166-167

Kakwata, Frederick 218-219

Kalu, Ogbu 119

Kanyatta, Jomo 197

Kaoma, Kapya 60, 62

Karambiri, Mamadou Philippe 255, 256, 259

Karambiri, Marie Sophie 254, 260, 261

Kaunda, Chammah 63

Kaunda, Kenneth 197

Kenneth Narh Scholarship scheme 216

Kenya 95; Neo-Pentecostal Charismatic Churches in 120; Pentecostalism in 121

Kientega, Innocent 244

Kimbangu, Simon 41, 119

Kingdom Prosperity model 290-291
Kingsway International Christian Center 45, 46

Kitonga, Arthur 120

knowledge: indigenous 2, 315; religious 2; situated 2; western 138

Kofi, Robert Ampiah 221

Korten, David 313-314

Krow, Solomon 231

Kuma, Afua 187

Kumi-Larbi, Nana Yaw 205, 206

land tenure systems 200

languages: indigenous 42; Nigerian 165; in Pentecostal Churches 105; vernacular 42

Larbi, Emmanuel Kinsley 184, 187

Latter Rain Assembly 131

Laudato Si' (Pope Francis) 59-60

Lausanne Movement 190

laws of purity 96

leadership: and the Holy Spirit 96; roles for women 108-109, 112-114; training for 96-97, 129

Lee, Christina 114

Lekganyane, Barnabas E. 15

Leslie, Handel 120

Le Tabernacle Béthel Israël/l'Eglise des Nations (Bethel Israel Tabernacle/All Nations' Church) 256

Levitical codes 37

Liberia 48

Lighthouse Chapel International 120

link-building 143

literacy programmes 128

Living Faith (aka Winner Chapel) 156

Living Faith Church Worldwide 43

Living Faith Ministries 154

local culture 6, 24-25; see also contextuality

localism 20

Lord's Supper 95, 186; see also eucharist

Lutheran Church see Evangelical Lutheran Church in America (ELCA)

Lutheran Church of Ghana 234

Lutheran World Federation 1

Magbadelo, John 155

Maggay, Melba 257

Mahama, Alihu 221

Mahama, John Dramani 191, 221

Mahero, John 14

Mali 257

Mananu-Hooper, Helena 236

Mandela, Nelson 257 
Manifesto for an Ecological Reformation of Christianity 57-58

market economy 13

Markwei, Ebenezer 221

marriage 95; Pentecostal attitudes toward 156-157; as social and spiritual phenomenon 156-157

Married and Singles Fellowship 108

Martey, Emmanuel 235

Marxism 197-198

Mashabela, Elias 18

materialism 152

material wealth 38

maternity centres 124

Maxwell, David 156, 290

Maxwell, John 220

Mbembe, Achille 311

McCauley, Ray 120

McKeown, James 184, 188-189, 205

McKeown, Sylvia 184

meat production, global 67-68

mechanistic world views 52

media initiatives 129

medical clinics 128

Mennonite Board of Missions 231, 235

Mennonites 231-232, 234-235

Mercy Ship International Floating Hospital 128

Methodist Church 38, 230; in Gambia 116

Methodist Church Ghana 209, 213, 221, 232-233, 234, 235

Methodist Church in Nigeria 167

microcredit schemes 167

microenterprise development 167

microfinance banks 141

micro insurance 12

military coups 200-201

Millennium Development Goals (MDGs) 9, 314

Miller, Donald E. 43, 47, 49

Mills, Dag Heward 120

Mills, David 187

mining, in Ghana 201

ministry, holistic 144-145

miraculous manifestations 121, 155, 270

Missio Dei (mission of God) 61-63, 217

missionaries: churches founded by 5 ; contributions of 165; Islamic 165

missionary Godfathers 4, 74

missionary work 256-257; holistic approach to 261-262; of the Redeemed Christian Church of God 143-145

Mission Churches 213; attitudes towards African Independent Churches 39; and development in Africa 40-42, 316; excommunication from 227; political and social involvement of 37-38; relationship with African Independent Churches 23, 227-238, 237; role of women in 107

mission schools 116-118

Modernisation Theology 320n3

Modernisation Theory 313

modernity 3, 52, 284, 285, 319; and

African Initiated Christianity 49; and development 314; multiple/plural conceptions of 79; and the prosperity gospel 121; and western development practices 312

modernisation: alternative approach to 314; and development 313

modernisation theory 285

moral economy 294-295

morality 42-43

moral rectitude 123

Mornon, Kojo 227

Moses Orimolade University 169

Mountain of Fire and Miracles Ministries 120

mpontu (development) 34

Munroe, Myles 220

Munyeza, Shingi 274

Musama Disco Christo Church 230

music: African 237; in Pentecostal Churches 105; songs 95

Muslims, participating at Good News Theological Seminary 236; see also Islam

Myers, Bryant L. 253

Nackabah, John 227

Nartey, Ezekiel 235

National Association for Bible Translation and Literacy (ANTBA) 246-247, 248

National Christian Elders Forum (NCEF) 158

National Day of Prayer 237

National Drug Law Enforcement Agency (NDLEA) 147

National Independent Pentecostal Church of Africa 8

nationalism 40-41

Nationalist Churches 5, 6, 95

National Liberation Council 229

National Youth Council 220

natural resources: mismanagement of 212; renewable 132

Ndoum, Paa Kwesi 221 
Nederduitsch Hervormde Kerk van Afrika 25n1

NEIO 313

neo-colonialism 138

neoliberal capitalism 87

neoliberalism 314, 316, 319

neo-Marxism 75, 78

Neo-Pentecostalism 119, 120, 203, 215, 285, 320n1; Charismatic 120; see also Perez Chapel International neo-prophetic movements 33, 37 nepotism 201-202

networking 143, 289-290

New Pentecostal Charismatic Churches (PCCs) 24; in Zimbabwe 267-280

New Realism 199

newspapers 165

New Temple Spiritual Church 112

Nigeria 15, 33, 38, 41, 45, 83, 119, 257; Aladura Churches as agents of social transformation 164-173; Aladura theology - the case of the Church of the Lord Worldwide 175-180; challenges of development in 172; church schools in 116; Evangelical Churches in 131; Independent Churches in 43; mission schools in 118; Neo-Pentecostal Charismatic Churches in 120; Pentecostal Churches in 21, 136; promoting sustainable development in the Pentecostal Church 115-133; Redeemed Christian Church of God 5; role of Pentecostalism in sustainable development 151-162; role of women in Pentecostal Churches 105-114; social transformational role of religion in 165-167; transformation and development in the Redeemed Christian Church of God 136-148; see also Aladura Churches; Redeemed Christian Church of God (RCCG)

Nima Temple 231

Niringiye, David Zac 261

Nkrumah, Kwame 39, 197

non-governmental organisations (NGOs)

$12,17,18,81,196$; agency role of 78-79; Christian 115, 118-119, 123, 125, 132, 244-246, 249; collaboration with 146; and development from below 78; and education 248-249; grassroots 317; impact of 91-92; in Pentecostal Churches 271; and SDGs 213; secular 118

Ntumy, M.K. 184 nutrition, global transition in 67-68

Nyamekye, Eric Kwabena 184

Nyamiti, Charles 60

Nyereyere, Julius 197

OAIC see Organization of African Instituted Churches

Obafemi Awolowo University 144

Obama, Barack 208

Obasanjo, Olusegun 144

occult groups 39

Odjidja, E.M.L. 229

Oduyemi, Roseline 108

Okoh, Daniel 12-13

Olokor, Friday 157-158

Omane-Antwi, Kwame Boasiako 191

omoluabi 123

One Ministry of God (OMG) 284; and the good life 296-297; housing cooperatives 294-295; politics of hope 296-298; theological and missiological orientations of 286-287

Onyinah, Opoku 184, 205

Operation Garikayi/Hlalani Kuhle 288

Operation Murambatsvina 288

Opoku, Kofi Asare 233

organisational theory 79

Organization of African Instituted Churches (OAIC) 4, 8, 25n4, 96, 97-98, 114; and AIC theology 100; decentralised livelihoods programme 12; theological education in 98-99; Theology Programme 98-99 orphanages 189

Orthodox Churches 4, 25n1, 62

Oshoffa, Samuel Bilewu 168

Ositelu, Gabriel 74

Ositelu, Josiah Olunowo 168

Ositelu, Rufus 171

Otabil, Mensa 15, 43, 45, 47-48, 120, 221

Ouédraogo, Abdoul Karim 260

out-of-body experience 110-111

Oyakhilome, Chris 120

Oyedepo, David 43, 120

Palm, Orthance 260

Pan-African Christian University College 218

Paradigms of Prosperity 19

Parham, Charles 203

partnerships 131; conditionality in 251-252; international 249-250; local 248; national 248-249

Passover 95 
Paul (apostle) 106, 114

Peace, Justice and Empowerment

Movement 171

peacemaking 259

Peasah, Angela 190

Pentecostal Association 233

Pentecostal Charismatic Christianity

(PCC) 284, 313; entrepreneurship and formalisation in 292-294; and the management of precarity in Zimbabwe 284-298; moral economy and housing provision 294-295; politics of hope 296-298; rationalisation and methodical lives in 290-292; spiritual security and agency 295-296; in SubSaharan Africa 291; theological and missiological orientations of 285-286

Pentecostal Charismatic Churches (PCCs): entrepreneurship workshops in 274-278; ethnography in 268-269; in Zimbabwe 267; see also African Pentecostal Charismatic Churches

Pentecostal Christian Churches, ethnography in 284-298

Pentecostal Churches 33, 62; African 143; as agents of sustainable development 195-209; classical 35; commonalities among 22; compared to Spiritual Churches 8; as development actors 311; dynamic growth in Africa 269-271; and the generation of social capital 87-90; modern 132; Nigerian 142; pneumatology of 61 ; recommendation of equality for women 109; role in Ghanaian society 183-193; role of 61; role of women in Nigeria 105-114; social transformation activities 164 ; sustainable development in 115-133, 151-152, 161-162; see also African Pentecostal Churches; Church of Pentecost; Pentecostal Charismatic Christianity (PCC); Pentecostal Charismatic Churches (PCCs); Pentecostal Christian Churches; Pentecostalism

Pentecostal Convention Centre (PCC) 189-190, 205-206

Pentecostalism: African 19, 38, 63, 119, 136, 139; and the African worldview 86; centrifugal approach of 151 ; civic engagement of 141-142; Classical 203; contemporary $37,43,45,49,85$; contemporary African 87; and development 213; emergence of in
Ghana 214-215; first wave movements 285, 298n2; fourth wave of 269; in Ghanaian society 183-193; global 6, 119; as global religious movement 269; and the Gospel of Prosperity 152-156; indigenous 183; in Kenya 121; in Latin America 25n5; missiology and development 204-205; and neo-liberal capitalism 284; new-wave 152, 155; in Nigeria 21, 161-162; Nigerian 46, 152-156; personhood and well-being in 288-290; progressive 206; sharing and caring in 160-161; and sociopolitical criticism 157-160; in South Africa 285; and sustainable development 271-272; and sustainable development (Perez Chapel International) 212-223; and sustainable development in Nigeria 151-162; third wave movements 285; transnational spread of 269; and Value for Money Conference 206-207; see also Church of Pentecost; Pentecostal Charismatic Christianity (PCC); Pentecostal Charismatic Churches (PCCs); Pentecostal Christian Churches; Pentecostal Churches; Pentecostal Churches

Pentecostal movement 36, 43; in Africa 119; global 6; in Nigeria 21

Pentecostal Theological Seminary 188, 206

Pentecostal World Fellowship 190

Pentecost Co-operative Mutual Support and Social Service Society Ltd. (PENCO) 189

Pentecost Educational Scholarship Scheme 189

Pentecost Social Services (PENTSOS) 189, 207

Pentecost University College (PUC) 187-188, 191

Pentecost Welfare Association (PENTWAS) 207

people centered development 78,313 , 319

Perez Academy 218

Perez Chapel International 16, 23, 205, 212-223; educational and development projects of 217-218; history of 215-217; and holistic development 218-223; Youth Explosion Programme 219-223

Perez University College 218

PIAC (Public Interest and Accountability Committee) 190 
pneumatic movements 19, 33, 34, 36; African 61

Pobee, John 74

political activism 22, 84-85, 270; and the Aladura Churches 168-170; see also civic engagement

political crises 284

political initiatives 129

politics 1; alternative approach to 83 ; in churches 84; and development from below 82; of hope 296-298

pollution 51

positive confession 153

postcolonial debate 2

postcolonialism 21, 138

postcolonial theory 16

Potter's House Church 45

poverty 122; in Africa 115; alleviation of 141, 167; deliverance from 13, 275; eradication of 262; spiritual warfare against 269,276

prayer 40, 64-65, 95, 179-180, 230, 261; extemporaneous 180; and healing ministry 165 ; as weapon against poverty 276

prayer gowns 96

prayer programmes 260

Praying Mothers Fellowship 108

precariousness, vs. precarity 287

precarity: management of 284-298;

precariousness vs., 287

Precious Stone Society 168

Precious TV 216

premillennialism 286

Prempeh, Sam 235

Presbyterian Church 38, 213; see also Evangelical Presbyterian Church

Presbyterian Church of Ghana 221, 229, 234, 235, 236

priesthood of believers 96, 178, 179, 186

prison ministry $127-128,167,190$, 258-259, 260

Progressive Pentecostals 43

prophecy 95, 96, 107, 179, 230, 270

prophet-healing churches $39-40$

prophetic-critical garbage theology 67

Prophetic Healing and Deliverance

(PHD) ministries 274, 278, 279

prophetic ministries 167

prophets 41, 119; in new Independent

Churches 44-45

prosperity 3; as divine right 43; sowing-

and-reaping approach to 44-45

prosperity gospel 7, 14, 139, 268, 269,
285-286, 287, 313; and development 272-274

prosperity principles $121,154-155$

prosperity teaching 153, 205

prosperity theology $13,24,33,36,37$, 43-45, 155

Protestant Ethic 13-14, 276, 285; and development from below 85-90

Protestantism 4; and global capitalism 275; see also Christianity;

Pentecostalism

public health 117

Public Interest and Accountability Committee (PIAC) 190

PUC (Pentecost University College) 187-188, 191

\section{Quran 165}

Rawlings, John Jerry 197, 205

RCCG see Redeemed Christian Church of God (RCCG)

Reach the People Ministries 190

Redeemed AIDS Programme Action Committee (RAPAC) 146

Redeemed Christian Bible College 147

Redeemed Christian Church of God (RCCG) 5, 8, 15, 21, 25n4, 43, 82-83, $92 \mathrm{n} 1,92 \mathrm{n} 2,116,120,151$; as agent of social transformation 143-145; campaign against drug abuse ministry 146-147; and Christian Social Responsibility (CSR) 125-130; and civic engagement 141-142; contributions to transformation and development of the Nigerian state 140-141, 148; educational approaches to development 147; expansion of 124-125; founding of 124; missionary ethos 143-145; under Pastor Adeboye 124-125; programmes for the poor 167 ; and the prosperity gospel 154; responding to social and health challenges 145-146; and social capital 142-143; and sustainable development 130-132, 156; transformation and development in 136-148; transnational branches 132; as world missionary player 141

Redeemed Gospel Church 120

Redeemer's Christian Fellowship (RCF) 145

Redeemer's University, Ede (RUN) 147 refugees, in Africa 204 
rehabilitation centres 127

religion: as agent of social control 166; alternative approach to 83 ; as atavistic form of knowledge 285; and development 1, 34-35, 79, 136-140, 147-148, 271-272, 285; and globalisation 164; influence on politics 166; and modernity 285; in Nigeria 165-167; as political force 142; and resilience 196; as social phenomenon 164; social transformational role of 165-167; and sustainability 51; in Third World countries 138; as tool for social transformation 164

religious capital 143, 147; see also spiritual capital

religious communities 285; and valuesbased development 195-196

religious fanaticism 137

religious studies 1

religious world views 17

repentance 95, 96

Research Programme on Religious

Communities and Sustainable

Development 73

resilience 196

resistance 16

Resurrection Youth Education Centre 167

Rhema Bible Church 120

rituals 36

ritual taboos 200

Roho Churches 5, 6, 95, 96, 100

Roman Catholic Church 59-60, 236; in Ghana 234; perceptions of the African Independent Churches 230; in Senegal 116; and Spiritual Churches 229; see also Catholic Church

Roth, Alice 231

Roth, Willard E. 231, 235

Sackey, E.A. 221

sacraments 95

Sacred Miracles Clinic Fellowship 234

Safo, Fred Stephen 184

Sakupapa, Teddy 61

Salem Evangelical Church of Christ 170

Salem Welfare Outreach of Nigeria 170

salvation 63, 118-119; and The Church of the Lord's (Prayer Fellowship)

Worldwide 177-178

Samaritan woman 106, 107, 112

Sanyal, Bishwapriya 75, 78

savings clubs 89

Schlemmer, Lawrence 82, 285 scholarships $12,128,130,189,215,216$, 278-279

schools, church-sponsored 12, 17, 43, 116, $125,128-129,147,154,165,168-169$,

213, 214, 244-246, 251, 256-257

Scripture Union (SU) 190, 220

Searcy, Kyre 221

Second Coming 38, 43

Sédégo, François de Paul 248-249

seed faith $280 \mathrm{n} 2$

seeding 272, 272-273

Sékou Touré, Ahmed 197

self-development 78, 81, 84; see also

development

self-help 81, 288

self-image 222

self-reliance 22

Self-Reliant Development 313

Sellassie, Haile 197

Sen, Amartya 314

Senegal 116, 257

Separatist Churches 5

sermons, by women 107

Seventh Day Adventist Church 234

Seymour, Joseph 203

shalom 123

Shanahan, Joseph 116

Sierra-Leone 257; church schools in 116

Simporé, Pastor 244

Sindima, Harvey 52, 52-53

Sisters Fellowship International 108

Sisters of St. Joseph de Cluny 116

slavery 185 ; opposition to 118

social action 21, 131

social capital 20, 21, 24, 90, 91, 147; and

development from below 87-90; and

the Redeemed Christian Church of God 142-143

social control 290

social engagement $47-48$

social initiatives $127-128$

social justice $21,84,131$

social media 272-273

social ministries 260,270

social networks 289-290

social service work 21, 22

social structures, local 17

social transformation 2

social welfare programmes $81-82,83,114$, 115, 191-192, 278; linked to

evangelism 132; by missionaries 116-119

Societies Act 97

Sokhanya Bible School 306 
Somdo/Abème, Jacqueline 260

Somé, Firmin 257

Sono, Mosa 120

sorcery, challengers of 119

South Africa 4, 8, 24, 33, 41, 79, 82;

African Independent Churches and decolonising development 311-320; cross-cultural development in 305-310; Dutch Reformed Church in 25n1; NeoPentecostal Charismatic Churches in 120; post-apartheid state in 83; Zion Christian Church in 5

South African Council of Churches (SACC) 60

South African Faith Communities Environment Institute (SAFCEI) 64, 66

Southern Africa 6, 15; see also South Africa; Zion Christian Church speaking in tongues 95, 110, 179, 270 Spirit Embassy (Good News Church) 278 spiritual capital 143; see also religious capital

Spiritual Churches 6, 33, 100; compared to Pentecostal Churches 8; in Ghana 228-229; see also African Independent Churches spiritual insecurity 295-296

spirituality: Pentecostal 105, 151; and socioeconomic development 16 spiritual warfare 295-296

spiritual world views $6-7,13,17,19,21,22$, 24; African 12-13, 14, 17-18; superseded by mechanistic world views 52

sports initiatives 129-130

Stepping Forth Halfway House 127

stewardship 122; environmental 64; as principle 155

street feeding programmes 127

structural adjustment 81, 118, 199

Structural Adjustment Programme (SAP) 199

sub-Saharan Africa, environmental protection in 54-55

substance abuse 219-220; challenges of 146; see also drug addiction

Sunsum soresee Spiritual Churches sustainability 23; in church-sponsored development 132-133; in CSR initiatives 125-126; defined 254; ecumenical definition of 55-56; in lifestyles 161; and the role of religions 51

sustainable development, sustainable 115-133, 151-162, 154, 310; additive vs. integral patterns 2; and African Initiated Christianity 3, 8; AIC programmes 236; Centre International d'Evangélisation/Mission Interièure Africaine's contribution to 253-262; challenges of promoting 130-132; challenges to 17; Christian thought on 122-123; and the Church of Pentecost (CoP) 205-206; defined 121-122, 212-213, 254; and ecological sustainability 9; and education 213,217 , 256; and employment opportunities 156; global discourse 121-122; and holistic development 212-213; link to education 154; local perspectives 123-124; and Pentecostal Churches 132-133; Pentecostal Churches as agents of 195-209; and Pentecostalism 271-272; and Perez Chapel International 23, 212-223; political infrastructure for 161 ; potentials and perspectives of African Initiated Christianinity 8-18; in religious communities $1-3$; religious infrastructure for 161; role of Pentecostal Churches in 151; socioeconomic infrastructure for 161 Sustainable Development Goals (SDGs) 2, 8-9, 12, 56-57, 142, 195, 213, 218, 314; and education (Goal \#4) 248-249, 252; and education for women and girls 243

Swaziland 64

taboos 96, 200

Tanne, Grace 227

Tapsoaba, Flavien 245

Tear Fund 196

technological training 169-170

televangelism 43, 110; North American 33

television productions 129

Ten Commandments 178

Ter Haar, Gerrie 183

terrorism 137

testimonies, personal 36

The Church of the Lord's (Prayer

Fellowship) Worldwide (TCLPFW):

and Aladura theology 175-180; and the Apostles' Creed 177; belife in salvation 177-178; on contemporary issues 178-179; and the Holy Trinity 177; practices and observances 179-180; and the priesthood of all believers 178; 
sacraments and festivals 177 ; six tenets of 175-177; and the Ten

Commandments 178

Theological Education by Extension (TEE) 98

theology 1; African 187; of African Initiated Churches 20, 35; in African Initiated Churches 95-100; of the Aladura Church 22, 25n3, 175-180; and contextuality 20; of development 216; dominionist 287; of garbage 67; oral 36, 100; of Pentecostal Charismatic Christianity (PCC) 285-286; postmillennial 286; recovering, documenting and updating 100

theology of prosperity 24

theory of religion (Nabofa) 164

Theovision International 190

Thompson, I.K.A. 233

tithes and offerings 44, 186, 188, 272-273

tithing 290, 298n10

town-hall meetings 129

Townsend, Henry 165

Tracy, Brian 220

trancing 107

transformation: in the community 123 ; ecological 51, 63-68, 67-68; economic 61 ; individual 14-15, 19, 123, 136, 270-271, 278; national 278; personal $42,85,85-87,86,90,91,144$; in the Redeemed Christian Church of God (RCCG) 136-148; social 121, 143-145, 164-173; socioeconomic 271

transnational corporations (TNCs) 54-55 transnational networks 37

tree planting 65

Trinity, belief in 105, 177

Trinity Theological Seminary 233, 237

Tunolase, Moses Orimolade 168

turbans 96

Turner, Harold W. 38-41

Twer Nyame (Divine Fellowship) 234

Ubuntu 3, 17, 317

Uganda 120

underdevelopment, in Africa 115

United Family International Church (UFIC) 272, 274, 278-279

United Methodist Committee 167

United Nations Development Program (UNDP) 56, 81, 137

United States, CIE/MIA churches in 257

United States Agency for International Development (USAID) 146 universities, church-sponsored 17, 43, 154, 165,169

University of Ibadan 145, 147, 167

University of Ilorin 145

UN World Summit (Johannesburg 2002) 217

Urhobo churches 167

Value for Money Conference 206-207

values: African 317, 320; indigenous 315; traditional African 20, 53

Victory Bible Church 221

Vision 2020 (Ghana) 199

visions 95, 96, 107, 110, 230; founding 99

vital force 60-61

vocational training $167,169-170$

volunteering 143

voter encouragement 15

voting see civic engagement

waithood 270

Walls, Andrew F. 35-37, 44, 253-254

Wariboko, Nimi 44, 45-46

Wartburg Theological Seminary 236

waste disposal management 67

water supply: inadequate 51 ; potable 214

wealth accumulation 291

Weaver, Edwin 231, 232

Weaver, Irene 231, 232

Weber, Max 13, 201

welfare groups 107

Welsh revival 184

Wesleyan Missions 117

West Africa 4, 6, 37, 41; African

Independent Churches in 105-106;

elections in 48; Pentecostal

diversification in 119-120; see also

Nigeria

White, Lynn 52, 53-54

white garment churches 96, 105, 108, 112, 180; see also African Independent Churches

Whiteman, Darrell L. 261

Widows Ministry 189

Winners' Chapel 43, 120, 151

wisdom, indigenous African 60-61

witchcraft, challengers of 119

women: in African Initiated Christianity 20-21; education for 243-252;

empowerment of 23, 306; in the Independent Churches 36; involved in sex trafficking 145; in leadership roles 96, 108-109, 112-114; and the Levitical codes 37 ; ordination of 186 , 
women continued

215; role of 105-114, 259-260; role of in Pentecostal Churches 105-114; as spiritual leaders pre-Christianity 106; theological education for 109

Women of Prayers in Nigeria Fellowship 108

Wontumi, Isaac 234

Woolnough, Brian 123

Word Miracle Church International 215; see also Perez Chapel International

Word of God, belief in 105

work ethics 166

World Bank 1, 81, 118, 137, 198-199, 216, 250

World Christian Encyclopedia (Barrett) 204

World Commission on Environment and Development 9, 121, 212, 254

World Council of Churches (WCC) 1, 56, 98; Bucharest (1974) 55

World Health Organization (WHO) 68, 170

worldview: indigenous 315; traditional African 119

World Vision 119, 196

worship services: of the Church of

Pentecost 187 ; style of 95

Wovenu, C.K. 39, 229-230

Wutawunashe, Andrew 120

Yamamori, Tetsunao 43, 47, 49
Yarboi, Tackie 221

Yeboah, M.K. 184

Yoruba churches 167

Yoruba culture 21, 117, 151, 157, 160-161; and development 123

youth camps 141

Youth Christian Political chamber 191

youth development 129-130

youth empowerment 24

Youth Explosion Programme 23, 219-221; influence of 221-223

ZAOGA 290; see Zimbabwe Assembly of God Africa (ZAOGA)

Ziai, Aram 16

Zimbabwe 24, 38, 42, 65; Christian NGOs in 119; Neo-Pentecostal Charismatic Churches in 120; New Pentecostal Charismatic Churches (PCCs) 267-280; Pentecostal Charismatic Christianity and the management of precarity 284-298; Pentecostal Churches in 156; precarity and uncertainties in 287-288

Zimbabwean Institute of Religious Research and Ecological Conservation 65

Zimbabwe Assembly of God Africa (ZAOGA) 292-293

Zion Christian Church 5, 8, 15

Zionist Churches 5, 6, 33, 74, 306, 312-313 